\title{
FACTORS ASSOCIATED WITH COMMITMENT OF REGISTERED DIETITIAN NUTRITIONISTS TO THE DIETETIC INTERNSHIP PRECEPTOR ROLE
}

\author{
by \\ Summer Lynn Butler
}

Dissertation Committee:

Professor Pamela Koch, Sponsor

Professor Randi L. Wolf

\begin{abstract}
Approved by the Committee on the Degree of Doctor of Education
\end{abstract}
Date _ May 22, 2019

Submitted in partial fulfillment of the requirements for the Degree of Doctor of Education

Teachers College, Columbia University 


\section{ABSTRACT}

\section{FACTORS ASSOCIATED WITH COMMITMENT OF REGISTERED DIETITIAN NUTRITIONISTS TO THE DIETETIC INTERNSHIP PRECEPTOR ROLE}

\section{Summer Lynn Butler}

Despite a shortage of Registered Dietitian Nutritionists (RDNs), only half of applicants currently match with a dietetic internship. A key reason is a shortage of preceptors. The purpose of this cross-sectional study was to better understand RDNs' views of the preceptor role. An online survey was sent to a randomly selected sample of $10 \%$ of RDNs. A total of 1,170 RDNs completed the survey. The survey collected data on reasons dietitians precept, training received, and incentives. Five scales measured supports, benefits, satisfaction, commitment, and barriers to the preceptor role. Three groups of RDNs - current (37.1\%), former (33.6\%), and never preceptors (29.3\%)—were compared and a regression analysis used to determine factors associated with precepting.

The main reason RDNs precept was to help the field. Two-thirds of respondents would precept if it were their choice, yet only $37 \%$ were current preceptors. RDNs were somewhat dissatisfied with incentives. Continuing Professional Education Units (CPEUs) for precepting was the most common incentive $(9.3 \%)$, while $35.6 \%$ received no incentives. 
The benefits scale mean scores were similar across the three groups, while current and former preceptors scored significantly higher $(\mathrm{p}<.001)$ than the never precepted group on the commitment, satisfaction, and support scales. The never group had significantly higher barriers $(\mathrm{p}<.001)$. The top barriers were increased stress from having interns, time-consuming/increased workload, and lack of incentives. Most (69\%) RDNs received no preceptor training.

Several factors were associated with being a current preceptor: fewer years as an RDN, Bachelor's degree as the highest degree, holding a specialization credential, working full-time, working/residing in urban areas, working for a DI program, being on a DI advisory committee, and higher commitment scale scores.

This study provides valuable insights for increasing RDNs who become preceptors, especially as the field transitions to the competency-based Future Education Model, which combines a graduate degree and supervised experiential learning. RDNs can be recruited as preceptors early in their career and encouraged to become members of advisory committees to connect them more to the preceptor role. Training for precepting can be widely provided, incentives improved, and barriers addressed to reduce stress for RDNs to precept. 
(C) Copyright Summer Lynn Butler 2019

All Rights Reserved 


\section{DEDICATION}

I would like to dedicate this work to my family, especially my mom and dad for their unwavering love and support. To my sister and brothers, for always being there, life would not have been the same without you. To my partner, for all of his patience and encouragement during this long journey, and to our children, Ciara, Maya, and Dante. May you believe in yourselves, feel free to be creative, carve your own path in life, and always speak loud enough to be heard. May you find something or many things you are passionate about and follow your dreams! Know your capabilities are vast and if there ever comes a time when you think you can't go anymore, just place one foot in front of the other, "breathe" and return to the moment, head to "the beach" or your happy place to refresh, use your support systems, show yourself compassion, and know that you are forever loved! Enjoy life and the opportunities it has to offer; some may come easily and others you will have to work harder than you ever imagined-but when you are done, you will feel accomplished!

To Grammy, who reminds me not to take life so seriously, and to the memory of Pop Pop, who was always our steady fan!

I would also like to dedicate my dissertation to all of my fellow, as well as future, RDNs - for all you do to enhance the field and contribute to the future of our profession as well as to the health and well-being of our communities. 


\section{ACKNOWLEDGMENTS}

I would like to acknowledge my dissertation advisor, Pamela Koch, for being there all hours of the day and night; her flexibility, guidance, and numerous Zoom calls were greatly appreciated. Pam, your work ethic and dedication are admirable and I am glad our paths have crossed in this way. I would like to thank my committee member and previous dissertation advisor, Randi Wolf, for her patience, honesty, advice, time management tips, and, most importantly, the high expectations she holds for doctoral candidates. Thank you to the Director of our Nutrition Program and committee member, Isobel Contento, for opening doors to opportunities during my time at $\mathrm{TC}$, and for your continued support, feedback, and encouragement. Thank you to my fourth committee member, Douglas Ready, your stats feedback and discussion were insightful and appreciated.

I would like to thank my parents who have always been there for me and who instilled the importance of family, commitment, and dedication.

I would like to thank my partner for his ability to always find a way to make me smile on those days when work seemed like it would never end and for always reminding me "todo va estar bien." Your continued support and encouragement during this time were deeply appreciated — it's been a long run! To my precious children, Ciara, Maya, and Dante, you have each brought a new light into my life during this journey. I thank you for your understanding, sitting next to me and sharing lots of hugs, kisses and massages when I was studying long hours. I know it was difficult.

I am thankful for my breastfeeding support system and for the encouragement and understanding I have received as a working mom. 
Thank you to all of my family, friends, and in-laws, especially my partner, my amazing parents, and my mother-in-law, for ensuring my children were in good hands, loved, hugged, learning and having fun while their "mamá" was working on her dissertation. Also thank you to my sister, Amber, for checking in on them as often as you did and to my brother Coty and sister-in-law Sasha for all the extra cuddles they love so much. You are all greatly appreciated and I could not have done it without you.

Holding a full-time job while completing my doctorate and raising little ones during the process has been a challenge, which is why I greatly thank my boss, Frank Biafore (and Sodexo), for his understanding, flexibility, and support while I furthered my education. I know you thought the day would never come. Sorry you'll have to find new jokes now.

Thank you to Sodexo for allowing me to send my pilot survey to Sodexo RDNs.

Thank you to the Commission on Dietetics Registration (CDR) for the approval to receive the full national list of RDN emails for this research topic.

I am so appreciative of all of my fellow co-workers, classmates, RDNs, and family/friends throughout the years who have read my work and provided honest feedback at various steps in the process. This includes several Dietetic Internship (DI) Directors, especially Christina Costa, previous Teachers College DI Director, for sharing your thoughts on the need for further research in this area, and although the topic has changed and evolved over the years, I thank you for planting the seed.

Thank you to Catherine Arnold, Professor and Chair of the Nutrition Department at Benedictine University, for sharing your survey process, experience, and feedback related to your research on precepting in dietetics. 
I would like to thank Heewon Lee Gray for your stats assistance during the pilot phase of my research and Laura Guerra for sharing your statistics background to guide me through the data analysis and oral defense preparation process. I would also like to thank Gabriella Oldham for your editing expertise.

I am so grateful to have you all as my village!

S. L. B. 


\section{TABLE OF CONTENTS}

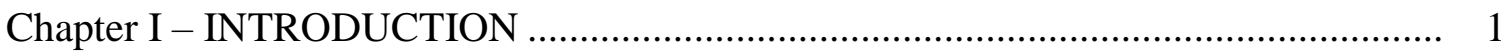

Chronic Diseases and Conditions ................................................................... 2

Role of Nutrition in Health Promotion and Disease Prevention.......................... 3

Background and Rationale for the Study .......................................................... 4

Registered Dietitians and Registered Dietitian Nutritionists ................... 4

RDN Supply and Demand ……………………………................... 5

How to Become an RDN?................................................................. 6

Dietetic Internship Supply and Demand .............................................. 7

Importance of the Dietetic Internship Supervised Practice Experience... 7

Preceptors................................................................................... 9

RDN Preceptors and Continuing Professional Education (CPE)

Requirements .............................................................................. 10

Volunteer Preceptors and Outreach Efforts to Decrease Preceptor

Shortage ................................................................................. 10

Literature Review Summary_What Do We Know About Precepting in

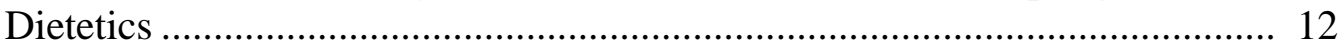

Perceptions of the Preceptor Role, Desired Knowledge, and

Skills of a Preceptor ....................................................................... 12

Training of Preceptors......................................................................... 13

Benefits, Motivators, Incentives to Precepting ...................................... 14

Support for Precepting ........................................................................ 16

Satisfaction With Precepting.................................................................. 17

Barriers to Precepting ........................................................................ 17

Commitment to the Preceptor Role in Dietetics ..................................... 18

Commitment to the Preceptor Role in Other Health-related Fields......... 18

Concluding Literature Review Summary ............................................. 19

Purpose of the Study ……………................................................................ 19

Statement of the Research Questions................................................................. 20

Significance of the Study ............................................................................ 21

Scope and Delimitations ................................................................................ 21

Abbreviations and Definitions of Terms............................................................ 21

Chapter II - REVIEW OF THE LITERATURE ……………....................................... 23

RDNs and Medical Nutrition Therapy (MNT) ………….................................. 23

Medical Nutrition Therapy Guidelines Related to Chronic

Diseases and Conditions and the Role of the RDN …….................... 24

Heart disease ........................................................................ 24

Diabetes-Type 2 ……………………………………......... 27

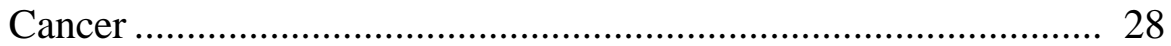

Osteoporosis..................................................................... 29

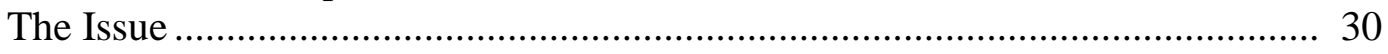

What Does the Research Tell Us About Precepting? ............................. 31 
Chapter II (continued)

Perceptions of the preceptor role, desired knowledge, and skills of a preceptor .................................................................. 31

Training of preceptors.............................................................. 32

Benefits, incentives, motivations to precepting in dietetics........... 33

Benefits, incentives, motivations to precepting in other health-related fields............................................................. 35

Support for precepting in dietetics ............................................. 37

Support for precepting in other health-related fields ................... 38

Satisfaction with precepting.................................................... 39

Barriers to precepting in dietetics ............................................... 40

Barriers to precepting in other health-related fields ..................... 40

Commitment to the preceptor role in dietetics.............................. 42

Commitment to the preceptor role in other health-related fields .... 42

Preceptor recruitment........................................................... 44

Summary Tables of the Studies ................................................................ 44

Summary of Rationale and Research Questions ........................................ 53

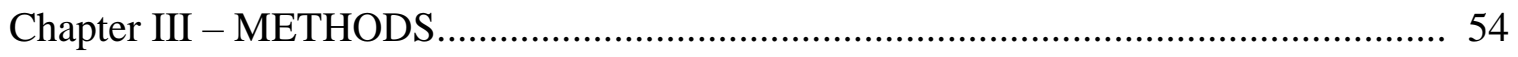

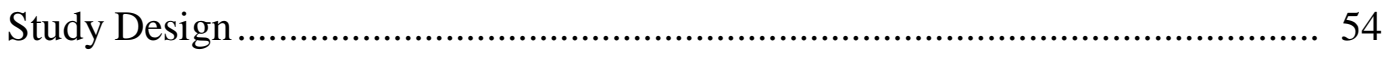

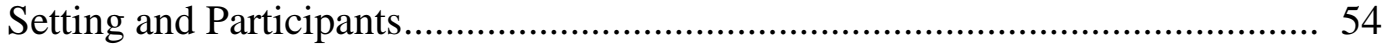

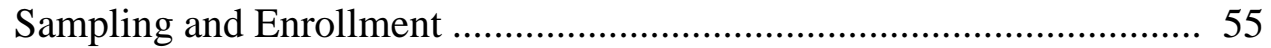

Data Collection ..................................................................................... 56

Pilot Study................................................................................. 57

The online questionnaire, reliability, validity ............................ 58

Main Study Measures ..................................................................... 78

Required Questions ................................................................ 78

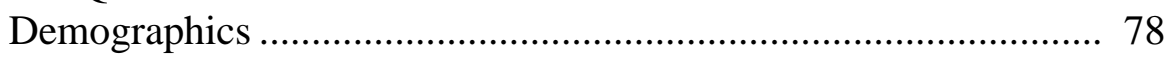

Dietetics/job-related information ........................................... 79

Preceptor-related questions .................................................. 80

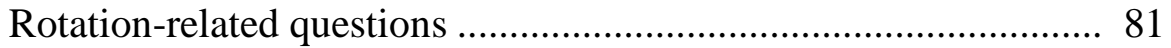

Benefits ....................................................................... 83

Motivators/incentives to precepting....................................... 85

Barriers to precepting.......................................................... 86

Support for the preceptor role ................................................ 87

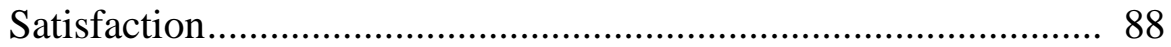

Commitment to the preceptor role .......................................... 89

Final additional questions ................................................. 90

Data Analysis Plan ............................................................................ 91

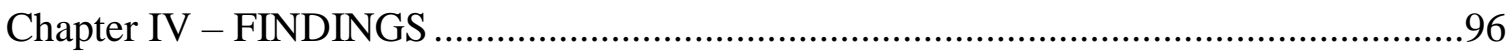

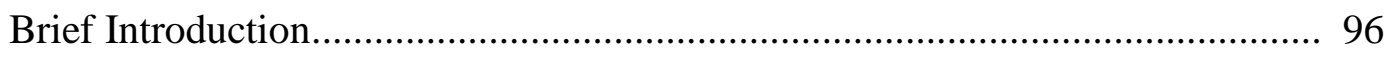

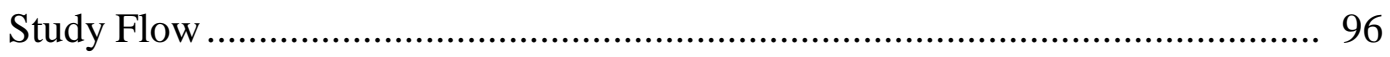

Characteristics of Registered Dietitian Nutritionists ..................................... 97

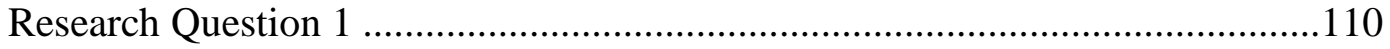




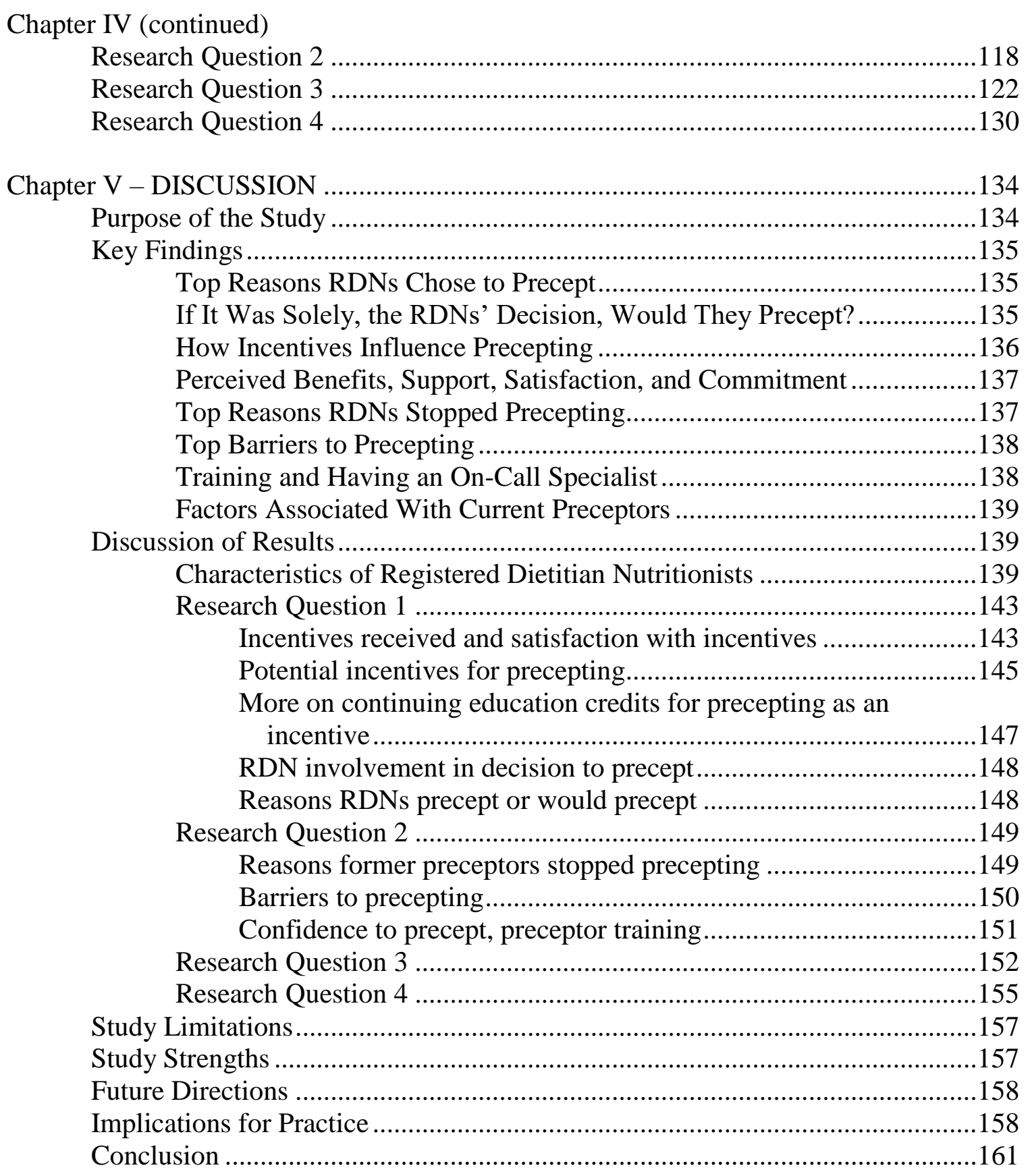

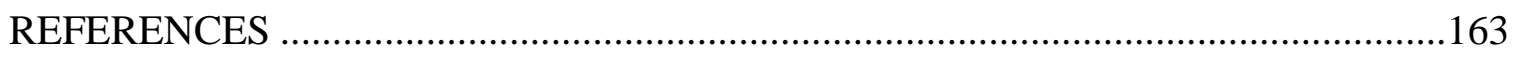


APPENDICES

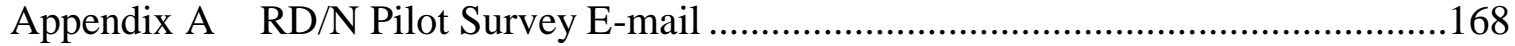

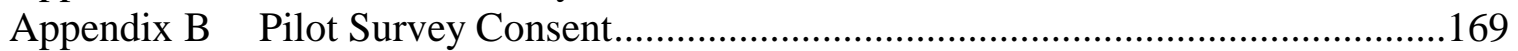

Appendix C RD/N Pilot Survey Reminder E-mail ...................................................170

Appendix D $\quad$ RD/N Retest Pilot Survey E-mail ....................................................171

Appendix E RD/N Retest Pilot Survey Reminder E-mail ......................................172

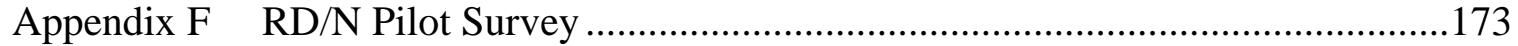

Appendix G RD Main Survey E-mail ...................................................................... 199

Appendix H RD Main Survey Reminder E-mail...................................................200

Appendix I $\quad$ RD Main Survey Retest E-mail ......................................................201

Appendix J RD Main Survey Retest Reminder E-mail............................................202

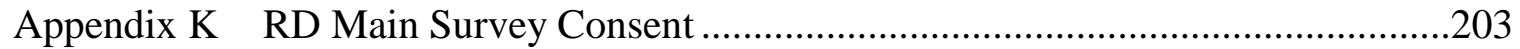

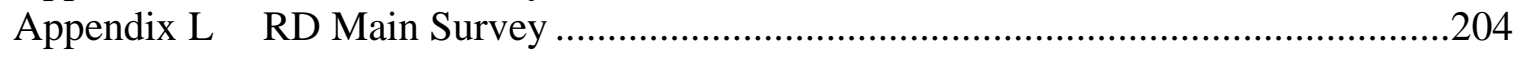




\section{LIST OF TABLES}

Table

2.1 Literature Review_-Precepting in Dietetics ............................................ 45

2.2 Literature Review_-Precepting in Other Health-Related Fields ...................... 48

3.1 Changes in Survey From Pilot to Main Study for Current Preceptors ............... 61

3.2 Changes in Survey From Pilot to Main Study for Former Preceptors ................ 68

3.3 Changes in Survey From Pilot to Main Study for Never Preceptors ................. 73

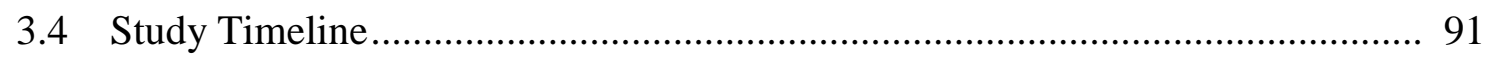

3.5 Research Questions, Measures, and Data Analysis Plan ............................... 92

3.6 Rationale for Factors Included in Regression Model .................................... 95

4.1 Characteristics of Survey Participants ....................................................... 100

4.2 RDNs' Own Dietetic Internship and Preceptor Experiences .............................103

4.3 Characteristics of Preceptors, Rotations, and so on .....................................106

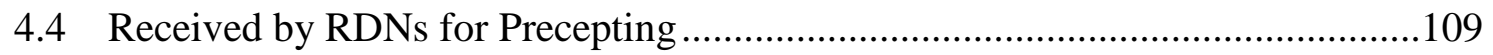

4.5 Why RDNs Precept/Precepted/Would Precept Dietetic Interns ........................111

4.6 Potential Incentives for Precepting, If Would Increase the Likelihood to

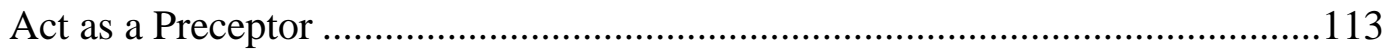

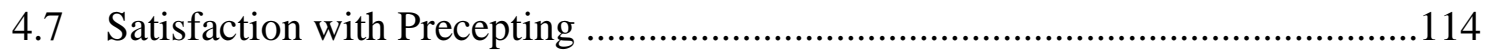

4.8 Continuing Education Credit for Precepting............................................ 115

4.9 If It Was Solely the RDNs' Decision, Would They Precept?...........................116

4.10 RDN Involved in Final Decision to Precept or Not to Precept ...........................117

4.11 Responses From Former and Never Preceptors Regarding Access to an On-Call Specialist

4.12 Barriers 
Table

4.13 Reasons Former Preceptors Stopped Precepting

4.14 Being an Effective Preceptor, Confidence in Knowledge and Skills, Need for Training.

4.15 Preceptor's Perception of Benefits and Rewards, Commitment to the Preceptor Role, Satisfaction, and Preceptor/'s Perception of Support Scale Scores - by Preceptor Status

4.15a Commitment to Preceptor Role 125

4.15b Satisfaction Related to Precepting .....

4.15c Perception of Support

4.15d Preceptor's Perceptions of Benefits and Rewards, Commitment to the Preceptor Role, Satisfaction, and Preceptor's Perception of Support Scale Scores

4.16 Correlations Among Benefits, Commitment, Satisfaction, Support, and Barrier Scale Totals

4.17 Correlations Among Variables in Final Regression Model

4.18 Binary Logistic Regression Analysis for Factors Predicting Preceptor Status ....133 


\section{LIST OF FIGURES}

Figure

1.1 Supply and demand for internship sites ................................................ 8

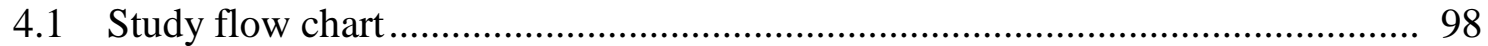




\section{Chapter I}

\section{INTRODUCTION}

Registered Dietitian Nutritionists (RDNs) play a critical role in preventing as well as managing numerous chronic diseases in the United States. It is predicted that by 2020 , the field will only be able to meet $75 \%$ of the need for dietetics practitioners (Commission on Dietetic Registration [CDR], 2012). To increase the number of RDNs to meet this demand, there needs to be an increase in the number of interns accepted into accredited programs, where they can complete the 1,200 hours of supervised practice required to be eligible for the registration exam. There are qualified applicants but there has been an internship shortage, and according to the Accreditation Council for Education in Nutrition and Dietetics (ACEND, 2013), volunteer preceptors have been a limiting factor. Understanding what influences whether or not RDNs become preceptors is increasingly important as ACEND is moving toward a new competency-based model, called the Future Education Model, that will require all supervised experiential learning to be combined with graduate degree programs (ACEND, 2018).

In order for programs such as dietetic internship programs and the Future Education Model to increase the number of slots available for preparing RDNs, they must find better ways to recruit and maintain supervised practice preceptors and rotation sites. Previous studies related to this topic in dietetics have been few and limited. The purpose 
of this study was to have a better understanding nationally of RDNs who precept, are former preceptors, or have never precepted, and factors associated with commitment to the preceptor role.

\section{Chronic Diseases and Conditions}

Stroke, heart disease, cancer, type 2 diabetes, and arthritis are considered to be among the most costly, common, and preventable of all our health problems. Half of the adults in America are said to have at least one chronic condition and about one in three have numerous chronic conditions. The more chronic conditions a person has, the higher the risk of premature death and hospitalization. Multiple chronic conditions are related to considerable health care costs, and an estimated $71 \%$ of health care spending in the United States is connected to Americans who have greater than one chronic disease or condition (Centers for Disease Control and Prevention [CDC], 2016).

Prevention and lifestyle modifications are especially important in the United States since heart disease is the primary cause of death, stroke has been linked to 1 in 18 deaths, cancer has taken more lives than heart disease, and osteoporosis affects $8 \%$ of adult females 20 and over. In 2008, there were at least 18 million (8\%) adults in the United States diagnosed with type 2 diabetes and the prevalence of diabetes has been projected to go up as high as 33\% of U.S. adults by 2050 (Academy of Nutrition and Dietetics [AND], 2013).

Diet-related chronic diseases and conditions include stroke, heart disease, cancer, osteoporosis, and diabetes. Health and wellness promotion, as well as disease prevention and management with an emphasis on improving dietary intake throughout the life span, 
is essential to well-being and quality of life, as well as assisting in controlling health care expenditures that otherwise will rise drastically as our population rises. Lifestyle modifications, including dietary modifications, may help prevent chronic disease, slow the progression or onset of certain diseases and conditions, and prevent disability or premature death related to chronic conditions (CDC, 2016; Krause, 2012).

\section{Role of Nutrition in Health Promotion and Disease Prevention}

Nutrition is an important component of primary, secondary, and tertiary prevention. "It is the position of the Academy of Nutrition and Dietetics that primary prevention is the most effective and affordable method to prevent chronic disease, and that dietary intervention positively impacts health outcomes across the life span" (Slawson et al., 2013, p. 1). Primary prevention emphasizes risk reduction, disease prevention, and health promotion. Secondary prevention includes early intervention, reducing risk, and decelerating the progression of conditions or diseases, such as preventing diabetes or delaying the onset for those that have prediabetes. Focus is on functionality and quality of life. Tertiary prevention includes more disease management and rehabilitation (Escott-Stump, 2015; Krause, 2012).

All prevention measures should incorporate what influences the individual's behavior and this involves a focus on the physical plus the social environment, including environmental determinants of health as well as disease. Examples of the social environment include neighborhood characteristics and media influences that could affect

dietary intake behaviors. Social ecological models have been considered useful since they focus on individuals, environmental factors, and the interaction between them. These 
models also comprise public policy and factors such as food labeling, pricing, agriculture, and dietary guidelines (Escott-Stump, 2015; Krause, 2012).

Federal Healthy People Goals for 2020 include prevention, living longer lives free of avoidable diseases and disabilities, creating physical and social environments that support the goal of health for everyone and foster healthy development, quality of life and healthy behaviors throughout all the stages of life, and eliminating health disparities and improving health designed for all groups (U.S. Department of Agriculture, accessed 2017).

Optimal health includes a nutritionally balanced diet and RDNs are uniquely trained and qualified to deliver nutrition education and interventions to promote a healthy lifestyle across the lifespan.

\section{Background and Rationale for the Study}

\section{Registered Dietitians and Registered Dietitian Nutritionists}

A Registered Dietitian Nutritionist (RDN) is a food and nutrition expert who is able to provide practical solutions towards healthy living. RDNs assist individuals in making positive lifestyle changes and work in various settings, such as hospitals, nursing homes, public health clinics, schools, food and nutrition management, food industry, academia, research, corporate wellness, sports, journalism, business, private practice, and more (AND, 2013).

The RDN terminology is a newer option for RDs that was started on RD Day 2013. RDN was added to demonstrate that all RDs are nutritionists but not all nutritionists are RDs. There is no difference between an RD credential and someone 
choosing to use the newer RDN credential; therefore, RD and RDN can and will be used interchangeably (AND, 2013). It is currently the decision of dietitians which credential they prefer to use.

\section{RDN Supply and Demand}

The Commission on Dietetic Registration (CDR) is the credentialing agency for the Academy of Nutrition and Dietetics (AND) and, as of April 12, 2016, the demographics of RDNs in the United States included 90,729 RDNs, with the registry growing 1-2\% each year (CDR, 2013). RDNs work in various areas of the field, including educational settings from preschool through college, health care facilities, senior living communities, corporations, and more. According to the Academy/CDR database (January 25, 2016), the highest self-reported areas of practice include general clinical nutrition $(19,530,20.6 \%)$, community nutrition $(7,545,8.0 \%)$, and food and nutrition management/administration $(4,337,4.6 \%)$.

In CDR's workforce demand study in 2011, there was only one DTR (Dietetic Technician, Registered) or RD for every 3,610 people in the United States. Data from 2010 from the U.S. Bureau of Labor Statistics on other professions showed that for each DTR or RD, there was one physician assistant, three pharmacists, and 33 nurses.

It was projected that by 2020 , the field will only be able to meet $75 \%$ of the need for dietetics practitioners, unless there is a dramatic increase in the supply. If we do not have enough RDs to meet the demand, other practitioners less educated in nutrition may move in to help meet the country's needs in this area (CDR PDP, 2012, p. 23). More recent data indicated that employment for nutritionists and dietitians, per the Bureau of 
Labor Statistics (accessed April 25, 2019), is expected to increase 15\% from 2016 to 2026, which is considered much higher than the mean for all jobs/professions (7\%).

\section{How to Become an RDN?}

There have been two main pathways to become an RDN:

1. One route is through a Coordinated Program (CP) accredited by ACEND (Accreditation Council for Education in Nutrition and Dietetics), which includes a bachelor or master's program combined with classroom and supervised practice experience. In the United States, there are total of $53 \mathrm{CPs}$ (ACEND Connection, February 2013). This includes 12 new (pilot) Future Education Model Graduate Programs (FG) (AND, accessed March 31, 2019).

2. The most common route and pathway of interest for this study is through completion of a Didactic Program in Dietetics (DPD), completing at least a bachelor's degree (approved or accredited by ACEND). Following degree completion, an ACEND-accredited Dietetic Internship (DI) Program must be completed. The DI Program has a separate and competitive application process. Some DI programs incorporate graduate coursework or a master's program, although they are not the same as CPs (ACEND, date). In the United States, there are a total of 225 Didactic Programs and 247 DIs (ACEND Connection, February 2013).

CPs and DIs (as well as a newer option discussed later, ISPPs [Individualized Supervised Practice Pathways]) all include supervised practice experience. Once one of these pathways is completed, the student/dietitian/nutritionist is eligible to take the Registration Exam for Dietitians to become an RDN. 


\section{Dietetic Internship Supply and Demand}

There is an internship shortage compared to qualified DI applicants. Supply and demand for DIs from 1993 through 2012 indicated the number of applicants has increased and there is a big gap between DI applicants and available DI positions. Matched DI applicants made up $72 \%$ of total applicants in 2003 , which decreased to 50.7\% in 2012 (ACEND Connection Online Update, May 2013), and only 47.5\% in 2016 (ACEND, Accessed 2017). Refer to Figure 1.1, Supply and Demand for Internship Sites. In dietetics, the majority of students apply to another postgraduate program, usually without the benefit of a graduate degree, to obtain the supervised practice experience. Other health professions in the United States completing supervised practice as part of the regulatory process, such as in medicine and nursing, have more combined programs that incorporate both didactic education and supervised practice into one, and this has been reported to help prevent internship shortages in other fields with supervised practice requirements (ACEND, April 2013).

\section{Importance of the Dietetic Internship Supervised Practice Experience}

The supervised practice experience is required in the United States to obtain the Registered Dietitian Nutritionist (RDN) credential. The Accreditation Council for Education in Nutrition and Dietetics (ACEND) that accredits Dietetic Internships (DI) requires 1,200 hours of supervised practice (AND, Careers in Dietetics, 2012). Each DI program decides how to allocate these hours, based on program goals, resources, and allowing the students sufficient time and practice in the varying roles of the dietitian to gain entry-level competence. They are also required to identify one to two areas of 
concentration and offer experiences and courses that expand on basic knowledge, as well as competencies.

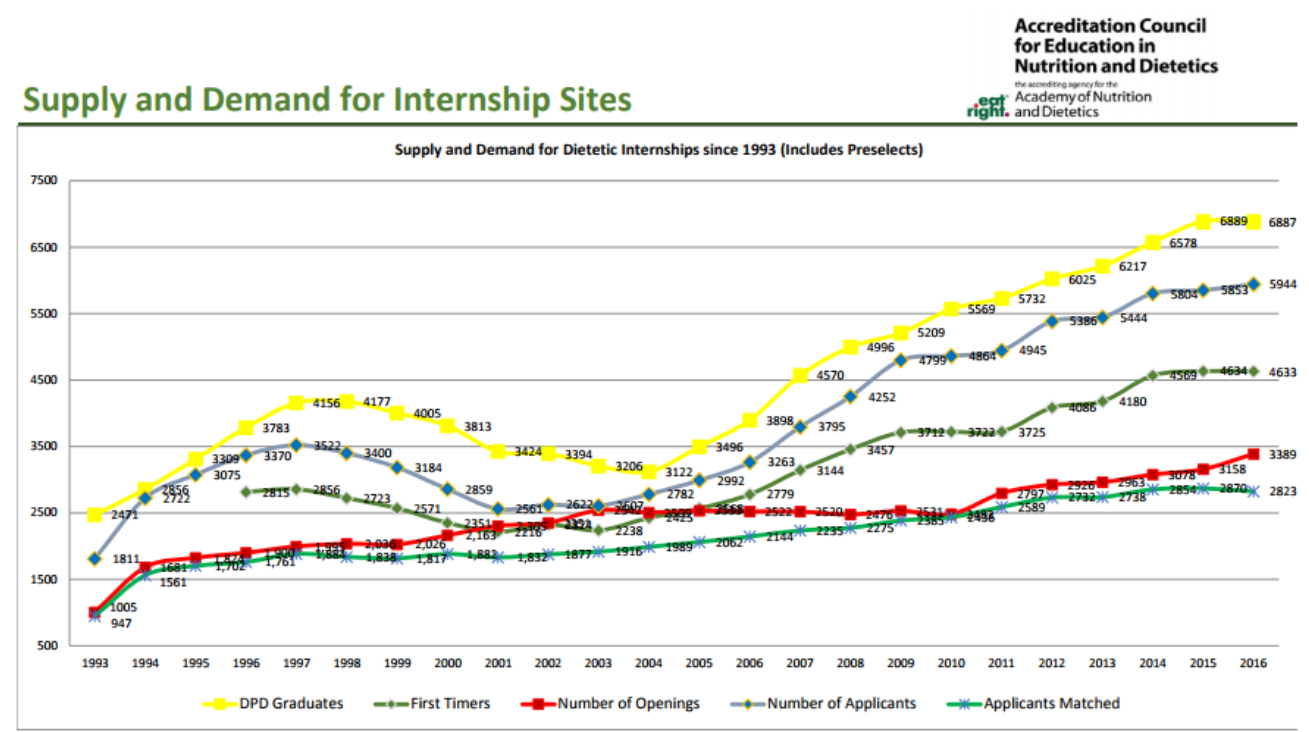

Figure 1.1. Supply and demand for internship sites

Source: ACEND, Availability of Dietetic Internship Positions. Supply and Demand for Internship Sites. http://www.eatrightpro.org/resource/acend/students-and-advancing-education/dietetic-internship-matchstudents/availability-of-dietetic-internship-positions, accessed July 3, 2017.

Supervised-practice facilities provide experiences to meet internship competencies (ACEND, Accreditation Standards for Internship Programs in Nutrition and Dietetics, 2012). Areas of supervised practice, where dietetic internships rely on preceptors, include rotations in settings such as inpatient medical nutrition therapy (hospitals/medical centers, rehabilitation, subacute, and long-term care facilities); outpatient medical nutrition therapy (i.e., diabetes, eating disorders, bariatrics); community nutrition (WIC, Cooperative Extensions, food banks); research, food service (hospital, school, corporate), management, and more.

Rotations may be set up and organized differently depending on the rotation facility, preceptor(s), and/or the DI program (i.e., university-based, hospital-based, food 
and nutrition contract company-based, distance program). At the supervised practice site/rotation itself, they may decide who chooses to take on interns or not, how many days/hours are acceptable, and other considerations.

\section{Preceptors}

Preceptors play a crucial role in nutrition as well as in many other health-related fields, assisting students in developing the skills needed to become competent entry-level practitioners. Dietetic Internship preceptors serve as faculty for interns during their supervised practice experiences, providing individualized training and modeling professional values and behaviors. Preceptors must demonstrate competency applicable to their precepting and teaching responsibilities through evidence such as appropriate degrees, experience, and continuing education (ACEND, 2012).

Preceptors may receive training via formal or informal in-services and/or trainings. An online Dietetics Preceptor Training is offered by the Commission on Dietetics Registration (CDR) free for up to eight CPEUs. According to the CDR's preceptor training modules, the role of the preceptor includes being role model, planner, information provider, resource developer, facilitator of learning, and assessor of learning.

Dietetic Internship preceptors will typically be, but are not required to be, RDNs. Nonetheless, the RDN credential may be required for their position, such as in a clinical role, or may be a requirement of the individual internship program. There may also be program-specific requirements for the RDN experience, such as preceptors being required to have at least 1 year of experience. In some states, there may also be statutes or regulations related to licensure or certification requiring a certain number of years of experience an RDN needs to have prior to co-signing an intern's note. 


\section{RDN Preceptors and Continuing Professional Education (CPE) Requirements}

The Commission on Dietetics Registration (CDR) is known as the credentialing agency for the Academy of Nutrition and Dietetics (AND), establishing and enforcing standards of certification, including the standards for the RDN credential. To maintain the RDN credential, RDs and RDNs are required to complete 75 CPEUs every 5 years, in conjunction with a portfolio process.

Continuing Professional Education (CPE) is education that is beyond that required to enter into the profession. It is lifelong learning that contributes to the maintenance and enhancement of the knowledge and skills necessary to remain competent in practice. CPE involves activities that are intended to go beyond typical employment responsibilities (CDR, 2016).

CPE activity types have included conventional self-study (web-based), exhibits, experiential skills development (example: topic Nutrition During Pregnancy), national meetings, poster sessions, residencies, and fellowship programs (example: Neonatal Nutrition Fellowship). CPE learning needs expand through various topics such as professional skills, time and stress management, life balance, science of food and nutrition, nutrition assessment and diagnosis, laboratory tests, wellness and public health, community program development, medical nutrition therapy, education, training, counseling, instructional materials development, coaching, mentoring, business and management, food service systems, culinary arts, research and grants.

\section{Volunteer Preceptors and Outreach Efforts to Decrease Preceptor Shortage}

DI directors and students who must find their own supervised practice rotation sites report difficulty obtaining as well as maintaining preceptors. Volunteer preceptors 
have been identified as the limiting factor to offering the amount of supervised practice experiences to match the demand coming from qualified dietetics students (ACEND, February 2013). A shortage of quality clinical site placements has also been a problem reported in Canada and beyond facing physical therapy and other health-related science programs (Hall et al., 2015).

Outreach to decrease the dietetics preceptor shortage has been underway in the field for some time now. In September 2011, the AND announced the Inclusion of Individualized Supervised Practice Pathways (ISPPs), which are intended to add supervised practice capacity through ACEND-accredited dietetics programs, providing student protections missing from the unaccredited models of the past, although the number of these programs is low. This approach provides a framework that can align the availability of supervised practice with demand from DPD students who hold verification statements, thereby laying the foundation for addressing supervised-practice shortages in the future. Preceptors are still part of this process and students contact preceptors or if dietitians are interested to precept, they can find programs in their area by visiting "Accredited Education Programs" and contacting program directors.

Increased efforts have been visible to retain preceptors as well as increase numbers of preceptors. At the start of a preceptor recruitment campaign in 2013, it was announced that AND leadership had declared April National Preceptor Month. During Preceptor Month, there are thanks and recognition in addition to recruitment. In April 2013, a Preceptor Drive was also started. AND in addition to ACEND developed a database for those interested to register as preceptors, where program directors can search for possible preceptors in their area or in a particular area of practice. Preceptor 
recruitment messaging and videos have also been evident on professional websites, under titles such as “Create Tomorrow’s Leaders-Become a Preceptor Today!” (AND online NCM, 2013). AND, per the request of ACEND, has funded Outstanding Preceptor Awards

on behalf of the Nutrition and Dietetic Educators and Preceptors (NDEP) DPG and ACEND to recognize preceptors who are exemplary educators and mentors. The awards cover complementary registration to attend meetings of the Food \& Nutrition Conference \& Expo (FNCE) along with reimbursement for travel, food, and lodging up to $\$ 1000$. The seven award recipients are recognized at the Academy Member Showcase and the NDEP Member Meetings at FNCE.

In 2015, a task force was formed to address the issue and focus on non-RDNs. In addition, effective June 2, 2017, CDR approved NDEP's proposal to grant RDNs continuing education credit to preceptors. Precepting will be incorporated under the Leadership Activity Type with a max of three CPEUs per year and 15 max for the 5-year recertification period for leadership and/or precepting activities (NDEP Area 7 Update email December 2, 2016).

\section{Literature Review Summary_What Do We Know About Precepting in Dietetics?}

A shortage of supervised practice experiences and preceptors, especially in the clinical arena, has been a reported problem in dietetics and other health-related science programs.

\section{Perceptions of the Preceptor Role, Desired Knowledge, and Skills of a Preceptor}

The "value of the preceptor role" has been viewed as high by dietetics and nutrition professionals (Winham et al., 2014). The desired knowledge of a dietetics preceptor has included holding advanced certifications; understanding new developments 
in the field; following evidence-based practice; having the ability to teach at different levels; assessing learner needs/learning styles; planning learning experiences to meet competencies; and implementing, evaluating, and providing practical training. Desired skills have included assessing, coaching, solving conflict, evaluating, planning, researching, teaching, facilitating, implementing, and managing time and leadership (Nasser et al., 2011). Dietetics preceptors have perceived their role to include a variety of tasks both essential and non-essential, including the responsibilities of a teacher and a mentor, although they may be less likely to carry out the role of mentor (Wilson, 2002).

\section{Training of Preceptors}

Barriers in precepting have included lack of training, preparation, structural supports, and planning. Dietetics preceptors have been found to have low scores regarding preparation for the preceptor role, with 58\% indicating no training, 32\% informal training, and 10\% formal training (Marincic \& Francfort, 2002). In another study by Wilson (2002), 30.2\% of dietetics preceptors participated in formal training and 87.9\% indicated training materials for precepting would be advantageous.

Training opportunities in dietetics for precepting have included formal (structured/planned), informal (unstructured/unplanned), and written resources. Barriers to preceptor training have included human resource issues such as it not being required or needed, or staff being overworked and/or unable to complete training. Organizational barriers have included staff workload as well as the logistics, costs, and time commitment of training (Nasser et al., 2011).

In a study by Winham et al. (2014) of a convenience sample of dietetic and nutrition professionals in Arizona $(\mathrm{N}=552)$, nonpreceptors did not report an equivalent 
level of confidence as former and current preceptors in their "ability to precept effectively," and there were significant differences between preceptors and nonpreceptors regarding certain preferred incentives, such as training on internship expectations and access to an "on-call" specialist for help or assistance with issues when they arise.

In a study on the educational needs of dietetics preceptors by Taylor, Hasseberg, Anderson, and Knehans (2010), it was concluded that training preceptors in adult learning, teaching and coaching skills, time management, and approaches for providing feedback could help establish a more successful and time-efficient preceptorship for all parties involved.

\section{Benefits, Motivators, Incentives to Precepting}

Precepting in dietetics has been viewed to be a professional contribution (Winham et al., 2014), provide a sense of achievement (Winham et al., 2014), improve teaching skills (Winham et al., 2014), increase professional knowledge (Marincic \& Francfort, 2002), inspire preceptors to work to the highest of their abilities (Marincic \& Francfort, 2002), keep preceptors current and stimulated in the field (Gilbride \& Conklin, 1996; Marincic \& Francfort, 2002; Winham et al., 2014), and increase awareness within the preceptor's area of practice/specialty (Winham et al., 2014). A large amount of departmental time while precepting has been found to be spent teaching (Conklin \& Simko, 1994). Current and former preceptors have agreed/strongly agreed that precepting is a professional obligation, while nonpreceptors were less likely to agree (Winham et al., 2014). Student projects have also been found to provide valuable information for updating policies and procedures (Gilbride \& Conklin, 1996). 
Although a low percentage of preceptors have reported receiving tangible rewards (8\%), benefits that have been offered for precepting in dietetics have included the use of libraries or recreational facilities, continuing education (CE) offerings, tuition waivers (2-6 credits/year), adjunct faculty status, textbooks, honorariums, lunches, stipends to professional meetings, subscriptions, invites to case study presentations, and professional consultation (Marincic \& Francfort, 2002). Receiving CE (continuing education) units for the act of precepting is done in other health-related fields and was approved in dietetics to start in June of 2017.

Winham et al. (2014) analyzed motivators to being a DI Preceptor in Arizona for RDs, DTRs, and school food service professionals (all eligible to precept) and found that the preferred incentive (nonmonetary) chosen by $70 \%$ of current preceptors, $74 \%$ of former, and $67 \%$ of those who never precepted was "CPEUs (continuing professional education units) for my field," followed by "expenses paid to a national conference," "ability to choose when to take an intern(s)," "pay for my time," "training on the internship expectations," "training on how to teach and communicate with interns," "official reduction in workload while intern there," and "access to an 'on-call' specialist for help or assistance with issues when they arise." Significant differences between preceptors' and nonpreceptors' responses were also found regarding three of the preferred incentives: "ability to choose when to take an intern(s)," "training on internship expectations," and "access to 'on-call' specialist for help or assistance with issues when they arise."

Winham et al. (2014) also found intangible rewards heightened the "value of the preceptor role" scale scores and appeared important for maintenance of current 
preceptors as well as provided an incentive for new practitioners to precept interns. In this same study, some nutrition and dietetics professionals reported they would precept without incentives, but more responses showed specific rewards (i.e., CPEUs, expenses paid to national conference, pay for time) would encourage them to take an intern. Support for the role of precepting, including from the internship director, their facility supervisors, and administration, could be more important in motivating professionals to precept than the monetary benefits.

\section{Support for Precepting}

In the study by Winham et al. (2014) of the convenience sample of dietetics and nutrition professionals in Arizona $(\mathrm{N}=552)$, support from the internship director, their facility's supervisors, and administration would make it more likely for professionals to precept. Institutional support scale scores were highest for current preceptors; however, overall the average score of 3.5 (on a 5-point scale) indicated support may be lacking. Nonpreceptors who perceived that there will be little workplace support were not likely to volunteer to precept. Lack of support in this area may be an important barrier (Winham et al., 2014). Ortman and Arsenault (2010) found dietetics preceptors also perceived program communication and website materials to be effective support, but they did not find WebCT (noted as new and unfamiliar) and video streams effective.

A positive correlation was found between perceived support and commitment to the preceptor role (Marincic \& Francfort, 2002) with lower scores seen in support than in benefits and rewards and commitment. Applications included improving support systems for preceptors, and as Ortman and Arsenault (2010) concluded, it may be important to 
identify preceptors' preferred method of communication in order to support them effectively in their role.

\section{Satisfaction With Precepting}

Dietetics preceptors have been found to be satisfied with their performance of their perceived responsibilities in their role (Wilson, 2002) and have found a sense of satisfaction seeing their students develop as professionals (Gilbride \& Conklin, 1996). Intangible benefits have been found to increase the "value of the preceptor role," even among nonpreceptors, and seem vital for current preceptor satisfaction (Winham et al., 2014).

\section{Barriers to Precepting}

In the study by Winham et al. (2014) of the convenience sample of dietetics and nutrition professionals in Arizona, the possible barriers to precepting interns included workload, intern liability, lack of compensation, lack of support, and lack of knowledge on becoming a preceptor, with only $17 \%$ aware of how to become a preceptor. A big concern was having time to do work as well as time to train the interns. The aspects most often noted by a small sample of current preceptors $(n=15)$ from a university-run DI program in Canada (Ortman \& Arsenault, 2010) were time constraints and the documentation burden. A large amount of departmental time, while precepting, was also found to be spent teaching in the study by Conklin and Simko (1994). Although this could be viewed as a positive for some who enjoy teaching or when net productivity is accounted for, it can also be considered a barrier to precepting. 
Negative perceptions of interns that came up as barriers in the Arizona study included challenging interns, unfavorable experiences, and the possible risk that interns could make mistakes that may cause clients harm, which was a response heard more from former and nonpreceptors (Winham et al., 2014).

In Taylor et al. (2010), some dietetics preceptors felt they should be compensated, and in Winham et al. (2014), 93\% of current preceptors reported they did not receive extra monetary compensation, while only $33 \%$ of the preceptors reported receiving a satisfactory amount of monetary compensation.

\section{Commitment to the Preceptor Role in Dietetics}

A strong commitment was seen in a dietetics preceptor $(\mathrm{n}=116)$ study by Marincic and Francfort (2002) towards the dietetics internship programs as well as for the preceptor role. There was a positive correlation between perceptions of rewards and benefits and commitment to the dietetics preceptor role. Lower scores were seen in support and commitment than in benefits and rewards and commitment.

\section{Commitment to the Preceptor Role in Other Health-related Fields}

Commitment to the preceptor role in nursing has been positively associated with a preceptor's perception of support (Blum, 2014; Dibert \& Goldenberg, 1995; Hyrkas \& Shoemaker, 2007; Natan et al., 2014), perception of benefits and rewards (Dibert \& Goldenberg, 1995; Hyrkas \& Shoemaker, 2007; Natan et al., 2014), as well as number of preceptor experiences (Dibert \& Goldenberg, 1995; Hyrkas \& Shoemaker, 2007). Nursing preceptors' perception of support has been found to increase with years of experience, age, and time since graduation (Hyrkas \& Shoemaker, 2007). 


\section{Concluding Literature Review Summary}

The published research on the benefits, barriers, motivators/incentives, support, satisfaction, and factors associated with commitment to the preceptor role in dietetics is dated and limited in scope and demographics (i.e., Marincic \& Francfort, 2002; Winham et al., 2014, specific to Arizona). Most of the studies are small in number, lack randomization of participants, and have minimally included nonpreceptors as participants. Research from other health-related fields, although also limited, can assist us in diving further into the preceptor issue in dietetics.

\section{Purpose of the Study}

There is a limited number of volunteer preceptors for qualified dietetic students (ACEND, 2013). The purpose of this study was to have a better national understanding of RDNs that precept, are former preceptors, or have never precepted; the reason(s) dietitians precept; the training and support they receive; their perception of benefits, motivators/incentives, and barriers to precepting; as well as their satisfaction with precepting and factors related to commitment to the preceptor role.

The goal was to provide stakeholders, such as Dietetic Internship (DI) Program Directors and students, with information that can be used to strategize ways to recruit new preceptors, maintain current preceptors, and/or increase the number of interns preceptors accept. The long-term goal was to decrease the preceptor shortage (with increased recruitment and commitment to precepting), and ultimately decrease the DI supervised-practice site shortage, ensuring an adequate number of quality DI slots are 
available to accept the number of qualified applicants to meet the nation's future demand for RDNs.

\section{Statement of the Research Questions}

RQ1: What incentivizes or motivates RDNs currently in the preceptor role to precept? What would motivate more RDNs to take on the preceptor role?

RQ2: What are the barriers to precepting for RDNs?

RQ3: What are the RDNs' perceived benefits, support, satisfaction, and commitment to the preceptor role?

RQ4: What factors are associated with RDNs being current preceptors?

\section{Significance of the Study}

There is an internship shortage compared to qualified DI applicants. Supply and demand for DIs from 1993 through 2012 indicated the number of applicants has increased and there is a big gap between DI applicants and available DI positions. Matched DI applicants made up $72 \%$ of total applicants in 2003, which decreased to 50.7\% in 2012 (ACEND Connection Online Update, May 2013) and only 47.5\% in 2016 (ACEND, Accessed 2017). According to ACEND (February 2013), volunteer "preceptors are the limiting factor in providing a sufficient number of supervised-practice opportunities for qualified dietetics students." This survey was developed to add more to the limited body of knowledge related to the national Dietetic Internship preceptor shortage. 


\section{Scope and Delimitations}

Study inclusion was defined to Registered Dietitian Nutritionists in the United States. Thus, study results cannot be generalizable to Dietitians outside of the United States. Also, since preceptors do not need to be RDNs, study results cannot be generalizable to all dietetic internship preceptors.

\section{Abbreviations and Definitions of Terms}

ACEND: The Accreditation Council for Education in Nutrition and Dietetics

AND: The Academy of Nutrition and Dietetics

CDR: Commission on Dietetics Registration

CP: Coordinated Program

CPEU/CPE/CE: Continuing Professional Education Units

CPR Scale: Commitment to Preceptor Role Scale

Dietetic Internship (DI): To apply for a DI, students must first complete at least a bachelor's degree and didactic program/ ACEND-accredited dietetic coursework. DIs may be combined with a master's degree (optional). DIs are required to provide at least 1,200 hours of supervised practice.

Dietetic Practice Groups (DPGs): These professional interest groups

enable members to enhance their specialized knowledge, share practice tips, and establish relationships with colleagues from all over the world. DPGs include a vast array of specialties, such as Diabetes Care and Education, Food and Culinary Professionals, Women's Health, Pediatric Nutrition, Health Aging and more. (AND, accessed October 8, 2016)

DTR: Dietetic Technician, Registered. DTRs "work under the supervision of the RD or RDN." 
ISPP: Individual Supervised Practice Pathway, newer option for students who may not get matched to an internship.

Preceptors: Dietetic internship preceptors act as a mentor, training dietetic interns during their supervised practice site rotations. Requirements to precept per ACEND "must be credentialed or licensed as appropriate to meet state and federal regulations for the area in which they work"; preceptors are not required to be an RD, and "must show evidence of continued competence appropriate to their...precepting responsibilities" (such as degrees, continuing education, experience, etc.). In 2012, the requirement for primary preceptors to have at least one year of work experience postcredentialing was removed (however, some internship programs or rotation sites may require a timeframe for experience).

MNT: Medical Nutrition Therapy

PPBS Scale: Preceptor's Perception of Benefits and Rewards Scale PPS Scale: Preceptor's Perception of Support Scale

Q: Question

RD, RDN: Registered Dietitian (RD) = Registered Dietitian Nutritionist (RDN), food and nutrition experts that have completed the requirements of a DI program (or an ISPP) and have passed the CDR dietetic registration exam. They are commissioned through CDR and in order to maintain their credential must complete a process which includes 75 CPE units every 5 years.

RQ: Research Question 


\section{Chapter II}

\section{REVIEW OF THE LITERATURE}

This chapter contains a thorough literature review of the importance of RDNs, what is known about RDNs in the preceptor role, and the methodology used to understand the preceptor role in other health professionals, such as nursing.

\section{RDNs and Medical Nutrition Therapy (MNT)}

Medical Nutrition Therapy (MNT) is considered the legal term used for nutrition counseling provided by an RDN. The nutrition care process conducted by an RDN consists of an assessment, nutrition diagnosis, and intervention(s) (including strategic counseling), followed by monitoring and evaluation (ADIME). It takes into account an individual's eating practices, food preferences, and lifestyle factors, and is based on assessment findings, intervention, and treatment goals, where individualized nutrition prescriptions and plans can be recommended or implemented. Multidisciplinary teams are essential and working collaboratively assists in empowering patients (Escott-Stump, 2015).

The Academy of Nutrition and Dietetics Evidence Analysis Library (2015, accessed January 4, 17) concluded there was strong evidence (Grade I, Good) to support "the effectiveness of nutrition interventions and counseling, provided by a nutrition professional (registered dietitian nutritionist or equivalent) when part of a health care 
team. Compelling evidence from 36 studies supports the multi-disciplinary team approach (including a nutrition professional) to improve" HbA1c, fasting blood glucose, homeostatic model assessment-estimated insulin resistance, fasting insulin, HDLcholesterol and LDL-cholesterol on numerous health conditions, such as in the management of diabetes, eating disorders, osteoporosis, cardiovascular disease, renal disease, and amytrophic lateral sclerosis (ALS).

MNT has been considered cost-effective, as evidenced in the Diabetes Prevention Program clinical trial. MNT provided to patients with diabetes, type 1 and 2, has been linked to improved glycemic outcomes. Key concepts in diabetes management include glucose control, blood pressure control, management of blood lipids, and preventative care for kidneys (Nutrition \& Diagnosis Related Care, 2015).

Although more research is still needed, there is evidence to support telenutrition counseling and interventions provided by an RD to result "in significant improvements" in certain areas, such as with serum lipids and hemoglobin A1C levels (Grade I, Good) (AND EAL, MNT: Telenutrition, 2012, accessed January 4, 2017).

\section{Medical Nutrition Therapy Guidelines Related to Chronic Diseases and Conditions and the Role of the RDN}

Heart disease. Risk factors for heart disease that can be positively affected by dietary modifications include high blood pressure, glucose intolerance, and dyslipidemia. Even though dietary adjustments have been shown effective, much work still needs to be done towards meeting population goals, such as the American Heart Association (AHA) 2020 goals, which include reducing death from stroke and heart disease by $20 \%$ and improving cardiovascular health. The AHA has defined "ideal cardiovascular health" as 
the existence of seven important behaviors and health factors as well as the absence of disease. Some of the goals for adults and children included in "Life's Simple 7" a "healthy" diet (4-5 components), physical activity (adults: i.e., 150+ minutes/week moderate), blood pressure (adults: $<120 /<80 \mathrm{~mm} \mathrm{Hg}$ ), cholesterol (adults: $<170$ $\mathrm{mg} / \mathrm{dL}$ ), and blood glucose (< $100 \mathrm{mg} / \mathrm{dL}$ ) (AND, 2013; AHA, 2013).

Medical nutrition therapy (MNT) provided by an RD has been shown to help lower blood pressure (BP) in adults with hypertension. Three studies on the effectiveness of MNT (under 6 months) found a significant decrease in BP by about five $\mathrm{mm} \mathrm{Hg}$ for both diastolic and systolic blood pressure. Five studies on the effectiveness of 6 to 12 months of MNT found significant decreases in BP and five studies reported maintenance of BP reductions over 1 year. Both group and individual sessions were conducted during an average of nine RD sessions (Grade: I good evidence, AND, Evidence Analysis Library, MNT: Effectiveness of MNT for Hypertension (2009), accessed January 4, 2017).

Decreasing intake of sodium to $<2400 \mathrm{mg} /$ day has been shown to lower BP by 2 to $8 \mathrm{mmHg}$; the DASH (Dietary Approaches to Stop Hypertension) eating plan has been shown to lower systolic BP an average of 8 to $14 \mathrm{mmHg}$; regular physical activity has been shown to lower BP 4 to $9 \mathrm{mmHg}$; and limiting alcohol to less than one daily drink for women and less than two daily drinks for men decreases BP on average by 2 to 4 mmHg (AND NCM, Hypertension: Nutrition Therapy Efficacy, accessed January 4, 2017). The nutrition therapy guidelines for hypertension include a sodium intake of $<$ $2400 \mathrm{mg} /$ day, recommended as part of the DASH eating plan, which is high in fiber, calcium, potassium, and magnesium, and limits fat, sweets, and sodium (1500- 
$2400 \mathrm{mg} /$ day). Intervention guidelines for hypertension include a focus on fruits, vegetables, whole grains, low fat dairy, fish, poultry, legumes, nuts, and vegetable oils. In addition to the DASH eating plan, following physical activity recommendations are suggested as effective in preventing and treating high BP (AND NCM, Hypertension: Nutrition Intervention, Nutrition Therapy Efficacy, accessed January 4, 2017).

There is strong evidence to support the effectiveness of 2 to 12 visits to an RDN or equivalent for MNT, consisting of a 60-minute initial and 20- to 45-minute follow-ups for adults with disorders of lipid metabolism. Evidence supports improvement in areas such as total cholesterol, HDL and LDL cholesterol, and triglycerides. Medical Nutrition Therapy including three or more RDN visits in $\leq 3$ months, and a $\geq 6$-week period for patients with disorders of lipid metabolism is supported to be cost-effective, resulting in improved cholesterol and triglyceride levels and a decrease in the use of medication. The more time spent with an RDN or equivalent also results in even greater improvements (AND EAL, MNT: Disorders of Lipid Metabolism (2015), Grade I good evidence, accessed January 4, 2017). MNT has also been shown to be cost-effective (compared to general physician care) for clients with high cholesterol (AND, 2013).

Nutrition therapy guidelines for improving LDL and HDL cholesterol levels include Therapeutic Lifestyle Changes (TLC), which consists of an eating plan low in trans fat, cholesterol ( $<200 \mathrm{mg} /$ day), and saturated fat ( $<7 \%$ of total energy), and increasing soluble fiber (17 to $30 \mathrm{~g}$ fiber- -7 to $13 \mathrm{~g}$ soluble fiber) if needed to further improve LDL $(\leq 7 \%)$. When needed, 2 to 3 grams daily of plant sterols or stanols (i.e., in cholesterol-lowering salad dressings and margarines) can be added to TLC to further improve LDL levels (lowering 7-15\%). Soy protein between 26 to 50 grams/daily may 
also help lower LDL levels. Physical activity at recommended levels of 30 minutes on all or most days can also help improve LDL and HDL levels. MNT by an RDN in two to six nutrition sessions can lower LDL levels by 7-14\% (AND NCM, Hypercholesterolemia, accessed January 4, 2017).

Additional recommendations for persons with high triglyceride levels may include lowering proportions of carbohydrate intake, avoiding extreme intake of fat and carbohydrate, limiting added sugars, eliminating alcohol, and adding polyunsaturated (i.e., omega-3) and monounsaturated fats into their diet. When needed, physicians may prescribe EPA and DHA omega-3 supplements to assist in decreasing triglyceride levels. Fish oil in supplement form may help lower triglyceride levels. However, evidence of their benefit is lacking in persons without heart disease and may be contraindicated with certain conditions (i.e., angina); therefore, it is recommended to be under medical supervision. If triglyceride levels are very high (> $500 \mathrm{mg} / \mathrm{dL})$, which may result from a genetic defect, total fat intake may be recommended to be lowered to below $15 \%$ of energy intake with elimination of alcohol in order to prevent pancreatitis (AND NCM, Hypertriglyceridemia, accessed January 4, 2017).

Diabetes-Type 2. Ninety to $95 \%$ of diagnosed diabetes cases are type 2 . Type 2 diabetes "is associated with a genetic predisposition for the disease, and the risk of developing type 2 diabetes increases with age, and lack of physical activity" (AND NCM, Type 2, accessed January 4, 2017). Diet has also been associated with the risk of type 2 diabetes, and nutrition-related modifiable predictors of diabetes have included high blood pressure, high triglyceride levels, and low high-density (HDL) cholesterol. Twelve percent of 12- to 19-year-olds have been found to have metabolic syndrome, which may 
predispose these individuals to the risk of type 2 diabetes. In addition, rates of diabetes are distinctly higher in minority populations (AND, 2013).

Medical nutrition therapy (MNT) for patients with diabetes is individualized based on factors such as age, existing comorbid conditions, time of diagnosis, medications, cardiovascular disease, and personal preferences. MNT goals for adults with type 2 diabetes include healthful eating patterns to meet glycemic, lipid, and blood pressure goals, as well as to prevent or delay the complications associated with diabetes. The monitoring of carbohydrate intake is an important strategy in reaching glycemic control, which can be accomplished through experience-based estimation or carbohydrate counting. Carbohydrate intake from fruits, vegetables, legumes, dairy products, and whole grains is suggested over other carbohydrate sources; consistency of daily carbohydrate intake at meals and snacks may be recommended, especially for patients on fixed insulin doses (AND NCM, Type 2, accessed January 4, 2017).

Cancer. Death from cancer has decreased, but in the United States continues to be the second common cause of death ( 1 in every 4 deaths), second to heart disease. In 2014, there was an estimate of $1,665,540$ newly diagnosed cancer cases and 585,720 deaths from cancer in the United States (AND NCM Oncology General Guidance, overview, accessed January 4, 2017). RDNs play an important role since nutrition-related risk factors include poor dietary intake and excessive adiposity. Dietary interventions are used for the primary prevention of certain cancers and decreasing fat intake has specifically shown to be effective in reducing the risk of ovarian and breast cancers (AND, 2013). 
Guidelines for cancer prevention include increased consumption of fruits, vegetables, whole grains, and legumes, and limited consumption of red meats, processed meats, alcohol, sugary drinks, energy dense foods, salty foods, and foods processed with sodium. Dietary supplements to guard against cancer are not recommended. Physical activity of 30 minutes or more a day is also recommended. Nutrition interventions are individualized to improve nutritional status and focus on issues related to weight and nutrition diagnoses. Nutrition interventions and care plans depend on various factors, such as cancer site(s), therapy/treatment plans, prognosis, treatment symptoms/side effects, diet and weight status/history, with consideration given as well to patient wishes, quality of life, and comfort. Strategies focus on maintaining lean body mass, preventing unintended weight loss, managing symptoms and adverse effects related to treatment that impact nutrition, preventing/reducing nutrient deficiencies, and preserving functional status. Patients with head and neck cancer as well as with certain gastrointestinal cancers may have to be fed via a tube and need assessment, nutritional intervention, monitoring, and evaluation to ensure needs are being met. Parenteral (or IV) nutrition in cancer patients is limited, if needed, to persons such as those with nonfunctioning gastrointestinal tracts or if it is anticipated there will be no enteral intake for 7 days and they are moderately to severely malnourished. Oncology patients need to be assessed, monitored, and educated accordingly to reduce their risk of infection (AND NCM, accessed 2017).

Osteoporosis. Osteoporosis is defined as structural deterioration, low bone mass, and a decrease in bone strength. Fractures resulting from osteoporosis can contribute to mortality and morbidity. Vitamin D and calcium intake play an important role in the 
prevention of bone fractures and dietary intake can have an influence on bone mineral density, in addition to bone loss. Nutrition recommendations for individuals with osteoporosis may include adequate vitamin $\mathrm{D}$, calcium and protein intake, moderate caffeine intake, and low to moderate sodium intake. Adequate fruit and vegetable intake may also help to ensure patients' needs are being met for other nutrients associated with bone health, such as vitamin A, potassium, and magnesium (AND NCM, accessed January 4, 2017).

\section{The Issue}

Optimal health and quality of life include a nutritionally balanced diet, and RDNs are uniquely trained and qualified to deliver nutrition education and interventions to promote a healthy lifestyle across the lifespan as well as across various medical conditions and disease states. Although ample candidates are applying to internship programs with the objective of becoming an RDN, there is an internship shortage compared to qualified DI applicants. A shortage of supervised practice experiences and preceptors, especially in the clinical arena, has been a reported problem in dietetics and other health-related science programs.

It is essential to ensure there are an adequate number of internship slots for qualified students to help the profession meet future demands for RDNs, and to assist students in obtaining a Dietetic Internship to complete the required 1,200 supervised practice hours to become an RDN. An important factor to accepting more interns involves the supervised practice rotation sites and preceptors available and willing/able to accept more dietetic interns. 


\section{What Does the Research Tell Us About Precepting? \\ Perceptions of the preceptor role, desired knowledge, and skills of a}

preceptor. The "value of the preceptor role" has been viewed as high by dietetic and nutrition professionals (Winham et al., 2014). The desired knowledge of a dietetics preceptor has included holding advanced certifications, understanding new developments in the field, following evidence-based practice, having the ability to teach at different levels, assessing learner needs/learning styles, planning learning experiences to meet competencies, implementing, evaluating, and providing practical training. Desired skills include assessing, coaching, solving conflict, evaluating, planning, researching, teaching, facilitating, implementing, managing time, and leadership (Nasser et al., 2011). Dietetics preceptors have perceived their role to include a variety of tasks, both essential and nonessential, including the responsibilities of a teacher and a mentor, although they may be less likely to carry out the role of mentor (Wilson, 2002).

In other fields such as pharmacy, residents have ranked their top five characteristics of effective preceptors as being a teacher (1), providing feedback (2), being knowledgeable (3), timely/able to manage time well (4), and are effective communicators (5) (Hartzler, Ballentine, \& Kauflin, 2015).

In the nation-wide convenience survey of dietetics preceptors $(\mathrm{N}=265)$ by Wilson (2002), participants were found to be confident in understanding their role as preceptor, with $83.2 \%$ of preceptors indicating they had an excellent/good understanding of role expectations and were also found to be satisfied with their performance of their perceived responsibilities. However, in another study of dietetics preceptors $(\mathrm{N}=116)$ by 
Marincic and Francfort (2002), low scores were found for preparation for the role and clarity of the responsibilities of a preceptor.

Training of preceptors. Barriers in precepting include lack of training, preparation, structural supports, and planning. Dietetics preceptors have been found to have low scores regarding preparation for the preceptor role, with $58 \%$ indicating no training, 32\% informal training, and 10\% formal training (Marincic \& Francfort, 2002). In another study by Wilson (2002), 30.2\% of dietetics preceptors participated in formal training and $87.9 \%$ indicated training materials for precepting would be advantageous.

Training opportunities in dietetics for precepting have included formal (structured/planned), informal (unstructured/unplanned), and written resources. Barriers to preceptor training have included human resource issues, such as it not being required or needed, or staff being overworked and/or unable to complete training. Organizational barriers include staff workload, as well as the logistics, costs, and time commitment of training (Nasser et al., 2011).

In a study by Winham et al. (2014) of a convenience sample of dietetic and nutrition professionals in Arizona $(\mathrm{N}=552)$, nonpreceptors did not report an equivalent level of confidence as former and current preceptors in their "ability to precept effectively," and there were significant differences between preceptors and nonpreceptors regarding certain preferred incentives, such as training on internship expectations and access to an "on-call" specialist for help or assistance with issues when they arose.

With preceptors working with undergraduate nursing and midwifery students when assessed in relation to their opinions on their roles, experience and education, challenges, and satisfaction, $36 \%$ of respondents reported undertaking education 
preparation for their role precepting, and differences were observed in three of the subscales (challenges, experience and education, and satisfaction) between preceptors who had training and those without training. Sixty-one percent of the preceptors had access to university-trained and paid facilitators on their ward and those with access to facilitators on their ward were more satisfied and scored higher in all domains (O'Brien et al., 2014).

In a study on the educational needs of dietetic preceptors, Taylor et al. (2010) concluded that training preceptors in adult learning, teaching and coaching skills, time management, and approaches for providing feedback could help establish a more successful and time-efficient preceptorship for all parties involved. Improved supervisor training sessions, as discussed in relation to physical therapists in Hall et al. (2015) where stress was associated with the supervisor's preparation to manage a student, may also assist preceptors in managing clinical rotation experiences and help lessen the stresses related to supervising and working with students.

Benefits, incentives, motivators to precepting in dietetics. Precepting in dietetics has been viewed as being a professional contribution (Winham et al., 2014), providing a sense of achievement (Winham et al., 2014), improving teaching skills (Winham et al., 2014), increasing professional knowledge (Marincic \& Francfort, 2002), inspiring preceptors to work to the highest of their abilities (Marincic \& Francfort, 2002), keeping preceptors current and stimulated in the field (Gilbride \& Conklin, 1996; Marincic \& Francfort, 2002; Winham et al., 2014), and increasing awareness within the preceptor's area of practice/specialty (Winham et al., 2014). A large amount of departmental time while precepting has been found to be spent teaching (Conklin \& 
Simko, 1994). Current and former preceptors have agreed/strongly agreed that precepting is a professional obligation, while nonpreceptors were less likely to agree (Winham et al., 2014). Student projects have also been found to provide valuable information for updating policies and procedures (Gilbride \& Conklin, 1996).

Although a low percentage of preceptors have reported receiving tangible rewards (8\%), benefits that have been offered for precepting in dietetics have included the use of libraries or recreational facilities, continuing education (CE) offerings, tuition waivers (2-6 credits/year), adjunct faculty status, textbooks, honorariums, lunches, stipends to professional meetings, subscriptions, invites to case study presentations, and professional consultation (Marincic \& Francfort, 2002). Receiving CE (continuing education) units for the act of precepting is done in other health-related fields and was approved in dietetics to start in June of 2017.

Winham et al. (2014) analyzed motivators to being a DI Preceptor in Arizona for RDs, DTRs, and school food service professionals (all eligible to precept) and found that of the respondents, $67 \%$ of those who have never precepted held RDs, $91 \%$ of current preceptors held RDs, and 95\% of former preceptors held RDs. Ninety-three percent of current preceptors did not receive any extra monetary compensation. The preferred incentive (nonmonetary) chosen by $70 \%$ of current preceptors, $74 \%$ of former, and $67 \%$ of those who never precepted was "CPEUs (continuing professional education units) for my field," followed by "expenses paid to a national conference," "ability to choose when to take an intern(s)," "pay for my time," "training on the internship expectations," "training on how to teach and communicate with interns," "official reduction in workload while intern there," and "access to an 'on-call' specialist for help or assistance with issues 
when they arise." Significant differences between preceptors and nonpreceptors responses were also found regarding three of these preferred incentives: "ability to choose when to take an interns(s)" (33\% current, $48 \%$ former, $64 \%$ never); "training on internship expectations" (29\% current, $49 \%$ former, $52 \%$ never); and "access to 'on-call' specialist for help or assistance with issues when they arise" (11\% current, 26\% former, $40 \%$ never).

Winham et al. (2014) also found intangible rewards heightened the "value of the preceptor role" scale scores and appeared important for maintenance of current preceptors as well as provided an incentive for new practitioners to precept interns. In this same study, some nutrition and dietetics professionals reported they would precept without incentives, but more responses showed specific rewards (i.e., CPEUs, expenses paid to national conference, pay for time) would encourage them to take an intern. Support for the role of precepting, including from the internship director, their facility supervisors, and administration, could be more important in motivating professionals to precept than the monetary benefits.

\section{Benefits, incentives, motivators to precepting in other health-related fields.}

Nursing benefits for precepting include CE credit offerings, books, decrease in tuition, and reimbursement to the preceptor or agency. Pharmacy preceptors can receive CE credit; for example, in North Carolina, preceptors must be registered as a preceptor with a college of pharmacy and can receive 4 hours of CE credit per student. If they precept two or more student, pharmacists receive five CE credits. Physician Assistants (PAs) can earn CME (category II) for recertification by precepting. Tangible benefits for PAs have also included adjunct faculty appointment, free CMEs and/or board review classes, training, 
university ID (can use for local discounts), use of library system, discounted tuition, and so on (source, year). Physicians can earn AAFP CME credits (up to max of 20 credits yearly) by precepting in family practice offices (American Academy of Family Physicians, 2012).

Findings related to the benefits and rewards, from a convenience sample of 200 Israeli nurse preceptors working in community and hospital settings, overall ranked fairly high, with intrinsic benefits ranking higher than extrinsic benefits, and with the highest intrinsic benefit being perceived as contribution to the profession (91\%) (Natan et al., 2014). Commitment to the preceptor role has been found to be positively associated with the perception of benefits and rewards (Dibert \& Goldenberg, 1995; Natan et al., 2014). When Hyrkas and Shoemaker (2007) duplicated the work done by Dibert and Goldenberg (1995), they found higher perceptions of benefits and rewards compared to earlier studies.

Research by Latessa, Colvin, Beaty, Steiner, and Pathman (2013) conducted in North Carolina surveying 1,278 community preceptors (pharmacists, physicians, physician assistants, advanced practice nurses - nurse practitioners and certified nurse midwives) found the perceived importance of reasons to precept students included giving back to the profession (99.4\%), demonstrating community practice (99\%), intellectual stimulation (98.7\%), enjoyment of teaching (98.5\%), being a role model (97.3\%), keeping their knowledge up to date (91\%), renewed importance to work (87.9\%), student appreciation of their teaching (84.4\%), student contribution to practice (72.3\%), helping recruit for their specialty (70.8\%), increasing practice status with patients (51.6\%), 
recruiting future partners $(46.6 \%)$, receiving other incentives $(41.3 \%)$, and receiving payments for teaching (32.4\%).

Support for precepting in dietetics. In an evaluation of the Iowa State University Dietetic Internship ( $\mathrm{N}=18$ preceptors), emerging themes of internship strengths, areas needing improvement, and preceptor and intern expectations and needs included preceptor networking, and effective feedback and communication between internship program/faculty, preceptors, and interns. It was noted that although the majority of preceptor participants had access to the internet, only $38 \%$ accessed the resources provided by the program via the internet. Geographic isolation could be related to the themes that surfaced (Kruzich, 2003).

Support categories that emerged in a small study by Taylor et al. (2010) of 31 females with a previous involvement in precepting included the nature of student and preceptor orientation, the teaching-learning environment, views of dietetic professionalism and responsibilities, and rewards of precepting.

In the study by Winham et al. (2014) of the convenience sample of dietetic and nutrition professionals in Arizona $(\mathrm{N}=552)$, support from the internship director, their facility's supervisors, and administration would make it more likely for professionals to precept. Institutional support scale scores were highest for current preceptors; however, overall the average score of 3.5 (on a 5-point scale) indicated support may be lacking. Nonpreceptors who perceived that there would be little workplace support were not likely to volunteer to precept. Lack of support in this area may be an important barrier (Winham et al., 2014). Ortman and Arsenault (2010) found dietetic preceptors also perceived 
program communication and website materials to be effective support, but they did not find WebCT (noted as new and unfamiliar) and video streams effective.

A positive correlation was found between "commitment to the preceptor role and perceived support" (Marincic \& Francfort, 2002), with lower scores seen in support than in benefits and rewards and commitment. Applications included improving support systems for preceptors, and as Ortman and Arsenault (2010) concluded, it may be important to identify preceptors' preferred method of communication in order to support them effectively in their role.

Support for precepting in other health-related fields. Important to note in the nursing field and in the interpretation of support data is that preceptors mentor nursing students as well as new nurses, while in dietetics, the preceptor role in the United States, as discussed in this dissertation, refers to the precepting of dietetic interns. Preceptors' perception of support in a small convenience sample (59) of nurses in a 400-bed urban teaching hospital was found to be positively associated with commitment to the preceptor role (Dibert \& Goldenberg, 1995). Preceptors' perceptions of support have also been found to increase with age, time that has passed since graduation, and years of experience (Hyrkas \& Shoemaker, 2007). In an Israeli study by Natan et al. (2014), nursing preceptors were found to have a moderate commitment to the preceptor role as well as a moderate perception of overall support, with the two areas ranking the highest related to support — namely, support by the head nurse of the department and by the employer's clinical coordinator. Only 58\% (of $n=200$ Israeli nurses) agreed teachers at the nursing school supported them and 64\% agreed the preceptor training course prepared them adequately for the role. The most important factor found to contribute to commitment to 
the role was support within the nurses' employment framework (using linear regression, model predictability $43.2 \%$ ). In this study, $74 \%$ of respondents worked with nursing students and $71 \%$ of respondents worked with new nurses.

Satisfaction with precepting. Dietetic preceptors have been found to be satisfied with their performance of their perceived responsibilities in their role (Wilson, 2002) and have found a sense of satisfaction seeing their students develop as professionals (Gilbride \& Conklin, 1996). Intangible benefits have been found to increase the "value of the preceptor role," even among nonpreceptors, and seem vital for current preceptor satisfaction (Winham et al., 2014).

Preceptors working with undergraduate nursing and midwifery students were assessed in relation to their opinions on their roles, experience and education, challenges, and satisfaction. Most of the respondents scored high in all areas assessed and were generally satisfied with the precepting role. Preceptors were less satisfied when it became time-consuming and when they had difficult or unmotivated students. Differences were observed in three of the subscales, one of which was satisfaction, between preceptors who had training and those without training. Sixty-one percent of the preceptors had access to university-trained and paid facilitators on their ward, and those with access to facilitators on their ward were "significantly more satisfied with their role" and scored higher in all domains (O’Brien et al., 2014).

In the research on community preceptors (not including dietetics) conducted by Latessa et al. (2013), overall satisfaction with precepting was high, but it was mentioned to be limited around the preceptor satisfaction topic, since it lacked detail about the small 
group of preceptors who responded negatively, and it was also noted how it would be interesting if there was a difference in preceptors vs. nonpreceptors.

Barriers to precepting in dietetics. In the study by Winham et al. (2014) of the convenience sample of dietetic and nutrition professionals in Arizona, the possible barriers to precepting interns included workload, intern liability, lack of compensation, lack of support, and lack of knowledge on becoming a preceptor, with only $17 \%$ aware of how to become a preceptor. A big concern was having time to do work as well as time to train the interns. The aspects most often noted by a small sample of current preceptors (n = 15) from a university-run DI program in Canada (Ortman \& Arsenault, 2010) was time constraints and the documentation burden. A large amount of departmental time while precepting was also found to be spent teaching in the study by Conklin and Simko (1994). Although this could be viewed as a positive for some who enjoy teaching or when net productivity is accounted for, it can also be considered a barrier to precepting.

Negative perceptions of interns that came up as barriers in the Arizona study included challenging interns, unfavorable experiences, and the possible risk that interns could make mistakes that may cause clients harm, which was a response heard more from former and nonpreceptors (Winham et al., 2014).

In Taylor et al.'s (2010) study, some dietetics preceptors felt they should be compensated, while in Winham et al.'s (2014) study, 93\% of current preceptors reported they did not receive extra monetary compensation and only $33 \%$ of the preceptors reported receiving a satisfactory amount of monetary compensation.

Barriers to precepting in other health-related fields. The problem reported in Canada and beyond facing physical therapy and other health-related science programs is 
the "shortage of quality clinical placement experiences." Research by Hall et al. (2015) focused on the factors that contribute to the decisions of Canadian Clinical Instructors supervising Physical Therapy students and the degree to which professional, personal, workplace/contextual, evaluation, and student factors play a role in their decision. A validated online survey was distributed via e-mail to all Canadian practicing physical therapists (PT) $(\mathrm{N}=18,110)$, of which 3,148 participated in the study. Results suggested a "6-factor structure contributing to the decision to supervise students: (1) clinical instructor feelings of stress, (2) student contribution to workplace efficiency, (3) dislike of assessment instrument, (4) clinical instructor preparation to evaluate, (5) student preparation and attitude, and (6) professional role and responsibility" (p. 58). Stress was the most important contributor that emerged in the survey in a PT's decision to supervise a student, and "the complexities of today's health care environment, coupled with the responsibilities of student supervision, appear to compound this stress.” This study reported confirming the

generalizability of constructs previously identified in exploratory studies, including dislike of the evaluation instrument and the professional role and responsibility of PTs to supervise students. Enhanced supervisor training workshops may enable PTs to better manage the clinical placement experience and mitigate the stresses associated with student supervision. A multipronged approach that includes consultation and partnership with all stakeholders is needed to resolve the issues of physical therapy student placement capacity.

It was noted in conclusion that an important component of stress seemed to be linked to the supervisor's preparation to oversee a student.

Hartzler et al. (2015) examined the challenges to preceptor development, assessed the status of preceptor development in pharmacy residency programs, and aimed at identifying directions for future opportunities for preceptor development. A total of 1,437 
preceptors and residents participated in the survey (survey included 19 preceptor-specific questions and 12 resident items). Most preceptors (88\%) felt they were adequately trained, but only $51.5 \%$ felt they had adequate time for precepting. The main barrier to their development as preceptors was a lack of time and $60 \%$ indicated their primary challenge was meeting employment responsibilities while being able to precept effectively.

Commitment to the preceptor role in dietetics. A strong commitment was seen in a dietetic preceptor $(n=116)$ study by Marincic and Francfort (2002) for dietetic internship programs as well as the preceptor role. There was a positive correlation between perceptions of rewards and benefits and commitment to the dietetic preceptor role. Lower scores were seen in support and commitment than in benefits and rewards and commitment.

Commitment to the preceptor role in other health-related fields. Commitment to the preceptor role in nursing has been positively associated with a preceptor's perception of support (Blum, 2014; Dibert \& Goldenberg, 1995; Hyrkas \& Shoemaker, 2007; Natan et al., 2014), perception of benefits and rewards (Dibert \& Goldenberg, 1995; Hyrkas \& Shoemaker, 2007; Natan et al., 2014), as well as number of preceptor experiences (Dibert \& Goldenberg, 1995; Hyrkas \& Shoemaker, 2007). Nursing preceptors' perception of support has been found to increase with years of experience, age, and time since graduation (Hyrkas \& Shoemaker, 2007).

The effect of the use of educational podcasts in nursing for preceptors and their commitment to the preceptor role was evaluated by Blum (2014), who found a significant 
increase, especially among participants with less experience, in precepting or less training, in a preceptor's perception of support.

In the Israeli nursing study, there was a moderate commitment to the preceptor role and support within the employment framework; moreover, benefits and rewards (intrinsic more than extrinsic) were found to be associated with commitment to the preceptor role. However, there was no correlation found between support outside the workplace, number of preceptees in the last 6 months, average number of preceptees per session, and commitment. The most important contributing factor to commitment was the nurses' employment framework (Natan et al., 2014).

Hyrkas and Shoemaker (2007) reported on a study that was designed to replicate the research done by Dibert and Goldenberg (1995) and Usher, Nolan, Reser, Owens, and Tollefson (1999). The purpose of the study was to increase knowledge and understanding about preceptorships and the preceptors' perceptions of rewards, benefits, support, and commitment to the role. A four-part questionnaire was used that included demographics, a PPS (Preceptor's Perception of Support) scale, a PPBR (Preceptor's Perception of Benefits and Rewards) scale, and a CPR (Commitment to Preceptor Role) scale. The sample included 82 preceptors, and a high commitment to the preceptor role was found. The more preceptors perceived there to be rewards and benefits, the more they were found to be committed to the preceptor role. There was a positive significant correlation between preceptors' perceptions of support and commitment to the preceptor role, with perceptions of support increasing with age, time since graduation, and years of experience nursing. This study showed preceptors to be committed, and even more so when perceived benefits and support were present. 
Preceptor recruitment. Skrabal et al. (2010) conducted a survey of a convenience sample of volunteer pharmacy preceptors associated with nine schools or colleges of pharmacy. Preceptors were considered volunteer if they were not faculty and if their salary was not paid by the university. The survey was distributed electronically via Microsoft FrontPage (initial e-mail and two follow-up reminders). The focus of the survey was experiential load or number of slots of student rotations, time commitment, and compensation. These factors were mentioned to directly affect preceptor recruitment and partnerships or participation with colleges or schools of pharmacy. A total of 4,396 preceptors were surveyed and $26.5 \%(1,163)$ responded. Full-time faculty were excluded, which totaled 33 respondents, providing a final sample size of $25.7 \%(1,130)$. Regarding practice settings, preceptors in hospitals took students from more schools, had more requests, also turned away a larger number of students, as well as spent less time with students when compared to the other settings. Preceptors in urban sites also took as well as turned away a larger number of students than those at rural sites. Practice type, location, and population density could affect preceptor experiences and recruitment.

\section{Summary Tables of the Studies}

Refer to Literature Review Table 2.1, Precepting in Dietetics, and Table 2.2, Precepting in Other Health-Related Fields. 
Table 2.1

Literature Review-Precepting in Dietetics

\begin{tabular}{|c|c|c|c|c|c|}
\hline $\begin{array}{c}\text { Author, } \\
\text { Publication, } \\
\text { Year, Location }\end{array}$ & $\begin{array}{c}\text { Final N, } \\
\text { Participants }\end{array}$ & Design, Instrument & $\begin{array}{l}\text { Main Study } \\
\text { Measures }\end{array}$ & Results Related to RQs & Comments (i.e., limitations) \\
\hline $\begin{array}{l}\text { I. Winham et } \\
\text { al., Topics in } \\
\text { Clinical } \\
\text { Nutrition, } \\
\text { (2014), Arizona }\end{array}$ & $\begin{array}{l}552: 161 \text { current } \\
\text { preceptors ( } 91 \% \\
\text { RD), } 113 \text { past } \\
(95 \% \text { RD), } 278 \\
\text { never }(51 \% \text { RD) }\end{array}$ & $\begin{array}{l}\text { Convenience Sample, } \\
\text { Online questionnaire } \\
\text { SurveyMonkey }\end{array}$ & $\begin{array}{l}\text { Attitudes, } \\
\text { perceptions of } \\
\text { preceptor role, } \\
\text { incentives, } \\
\text { support }\end{array}$ & $\begin{array}{l}\text { Value of preceptor role high. } \\
\text { Current/Former preceptors: sense of } \\
\text { achievement, improve teaching skills, } \\
\text { professional contribution/obligation, keeps } \\
\text { up to date and stimulated. Possible } \\
\text { incentives: specific rewards (i.e., CPEUs), } \\
\text { support for role. Possible barriers: negative } \\
\text { aspects of interns, lack of confidence in } \\
\text { ability to precept, lack of financial } \\
\text { compensation, } 17 \% \text { aware how to become } \\
\text { preceptor. }\end{array}$ & $\begin{array}{l}\text { Limitations: convenience } \\
\text { sample, specific to Arizona, } \\
\text { structure of instrument } \\
\text { mentioned may not identify } \\
\text { other key motivators/barriers. } \\
\text { Strengths: large sample size } \\
\text { for DI preceptor studies, } \\
\text { includes nonpreceptors and } \\
\text { participants with varying } \\
\text { preceptor experiences. }\end{array}$ \\
\hline $\begin{array}{l}\text { II. Nasser et al., } \\
\text { Canadian } \\
\text { Journal of } \\
\text { Dietary } \\
\text { Practice and } \\
\text { Research } \\
\text { (2011), Canada }\end{array}$ & $\begin{array}{l}49 \text { key informant } \\
\text { dietitians ( } 20 \\
\text { clinical, } 17 \\
\text { community/public } \\
\text { health) }\end{array}$ & $\begin{array}{l}\text { Qualitative, Online } \\
\text { 6-item open-ended } \\
\text { survey (SurveyMonkey) }\end{array}$ & $\begin{array}{l}\text { Domains: } \\
\text { knowledge, skills, } \\
\text { attitudes; training }\end{array}$ & $\begin{array}{l}\text { Desired knowledge for preceptors: } \\
\text { teaching-learning, assessing learner } \\
\text { needs/styles, planning experiences, } \\
\text { implementing, evaluating, evidence-based } \\
\text { practice, etc. Desired skills: assessing, } \\
\text { coaching, solving conflict, communicating, } \\
\text { evaluating, planning, researching, etc. } \\
\text { Other: leadership. Barriers to training: HR, } \\
\text { organization, training issues. }\end{array}$ & $\begin{array}{l}\text { Limitations: small sample, } \\
\text { specific to precepting in } \\
\text { Canada. }\end{array}$ \\
\hline $\begin{array}{l}\text { III. Taylor et } \\
\text { al., Journal of } \\
\text { Allied Health } \\
\text { (2010), Large } \\
\text { metropolitan } \\
\text { area (US) }\end{array}$ & $\begin{array}{l}31 \text { ( } 22 \text { clinical } \\
\text { dietitians, } 5 \text { recent } \\
\text { graduates } \\
\text { precepted during } \\
\text { training, } 4 \text { dietetic } \\
\text { faculty teach } \\
\text { courses with } \\
\text { precepting) }\end{array}$ & $\begin{array}{l}\text { Semi-structured focus } \\
\text { group, individual } \\
\text { interviews }\end{array}$ & $\begin{array}{l}\text { Educational needs } \\
\text { of the preceptor }\end{array}$ & $\begin{array}{l}\text { Central category: lack of time. Four } \\
\text { support categories emerged: nature of } \\
\text { student and preceptor, teaching-learning } \\
\text { environment, views of dietetic } \\
\text { professionalism, responsibilities and } \\
\text { rewards of precepting. }\end{array}$ & $\begin{array}{l}\text { Limitations: very small } \\
\text { sample of preceptors }(22) \text {, } \\
\text { hospital setting. Strength: } \\
\text { noted as "one of the only } \\
\text { studies to identify preceptor } \\
\text { training needs for dietetic } \\
\text { professionals." }\end{array}$ \\
\hline
\end{tabular}


Table 2.1 (continued)

\begin{tabular}{|c|c|c|c|c|c|}
\hline $\begin{array}{c}\text { Author, } \\
\text { Publication, } \\
\text { Year, Location }\end{array}$ & $\begin{array}{c}\text { Final N, } \\
\text { Participants }\end{array}$ & Design, Instrument & $\begin{array}{l}\text { Main Study } \\
\text { Measures }\end{array}$ & Results Related to RQs & $\begin{array}{l}\text { Comments (i.e., } \\
\text { limitations) }\end{array}$ \\
\hline $\begin{array}{l}\text { IV. Ortman \& } \\
\text { Arsenault, } \\
\text { Canadian } \\
\text { Journal of } \\
\text { Dietary } \\
\text { Practice and } \\
\text { Research } \\
\text { (2010), Canada }\end{array}$ & $\begin{array}{l}15 \text { current } \\
\text { preceptors from } \\
1 \text { university-run DI } \\
\text { program } \\
\text { ( } 4 \text { administrative, } \\
5 \text { clinical, } \\
6 \text { community) }\end{array}$ & $\begin{array}{l}\text { Questions posted, online } \\
\text { discussion group }\end{array}$ & $\begin{array}{l}\text { Perceived roles, } \\
\text { benefits, supports } \\
\text { for preceptors }\end{array}$ & $\begin{array}{l}\text { Lack of consensus on preceptor role, } \\
>50 \% \text { felt role is to provide supportive } \\
\text { safe learning environment. Benefits: } \\
\text { preceptors' academic/professional } \\
\text { enhancement, intern contributions to } \\
\text { organization. Negative aspects: time } \\
\text { constraints, documentation burden. } \\
\text { Supports: program communication and } \\
\text { website materials (not effective-WebCT } \\
\text { and video streams). }\end{array}$ & $\begin{array}{l}\text { Limitations: preceptors from } \\
\text { one dietetic internship } \\
\text { program, very small sample, } \\
\text { limited feedback. }\end{array}$ \\
\hline $\begin{array}{l}\text { V. Kruzich et } \\
\text { al., Journal of } \\
\text { the American } \\
\text { Dietetic } \\
\text { Association } \\
\text { (2003), Iowa }\end{array}$ & $\begin{array}{l}18 \text { preceptors from } \\
1 \text { university DI } \\
\text { program } \\
\text { (preceptors of the } \\
\text { program located in } \\
\text { various facilities) }\end{array}$ & 3 preceptor focus groups & $\begin{array}{l}\text { Evaluation of a } \\
\text { DI, internship } \\
\text { strengths, areas } \\
\text { needing } \\
\text { improvement, } \\
\text { preceptor and } \\
\text { intern } \\
\text { expectations and } \\
\text { needs }\end{array}$ & $\begin{array}{l}\text { Emerging themes: preceptor networking, } \\
\text { effective feedback, communication } \\
\text { between internship program/faculty, } \\
\text { preceptors and interns. }\end{array}$ & $\begin{array}{l}\text { Limitations: results noted } \\
\text { may be related to minimal } \\
\text { use of internet and } \\
\text { geographic isolation } \\
\text { (majority access to internet } \\
\text { but only } 38 \% \text { accessed } \\
\text { resources provided on } \\
\text { internet). }\end{array}$ \\
\hline $\begin{array}{l}\text { VI. Marincic \& } \\
\text { Francfort, } \\
\text { Journal of the } \\
\text { American } \\
\text { Dietetic } \\
\text { Association } \\
\text { (2002) }\end{array}$ & $\begin{array}{l}116 \text { dietetic } \\
\text { preceptors, from } \\
\text { traditional } \\
\text { internships and } \\
\text { supervised practice } \\
\text { by regional } \\
\text { affiliates }\end{array}$ & $\begin{array}{l}\text { 4-part questionnaire: } \\
\text { demographics, } \\
\text { commitment, } \\
\text { benefits/rewards, } \\
\text { support (from Dibert \& } \\
\text { Goldenberg, nursing) }\end{array}$ & $\begin{array}{l}\text { Preceptors' } \\
\text { perceptions of } \\
\text { rewards/benefits } \\
\text { (focus } \\
\text { intangible), } \\
\text { support, } \\
\text { commitment to } \\
\text { role }\end{array}$ & $\begin{array}{l}\text { Strong commitment to role and DI } \\
\text { programs. Benefits/rewards: keeps current } \\
\text { and interested in profession, increases } \\
\text { knowledge base, inspires them to perform } \\
\text { their best. Positive correlation between } \\
\text { perceptions of benefits/rewards and } \\
\text { commitment. Positive correlation between } \\
\text { commitment and perceived support. Low } \\
\text { scores for clarity of responsibilities and } \\
\text { preparation for preceptor role, } 58 \% \text { no } \\
\text { training, } 32 \% \text { informal, } 10 \% \text { formal. }\end{array}$ & $\begin{array}{l}\text { Limitations: focus on } \\
\text { intangible benefits. } \\
\text { Strengths: DIs and } \\
\text { preprofessional practice } \\
\text { programs were randomly } \\
\text { selected ( } 20 \text { total), then } \\
\text { surveys to preceptors in } \\
\text { programs. }\end{array}$ \\
\hline
\end{tabular}


Table 2.1 (continued)

\begin{tabular}{|c|c|c|c|c|c|}
\hline $\begin{array}{c}\text { Author, } \\
\text { Publication, } \\
\text { Year, Location }\end{array}$ & Final N, Participants & Design, Instrument & $\begin{array}{l}\text { Main Study } \\
\text { Measures }\end{array}$ & Results Related to RQs & $\begin{array}{l}\text { Comments (i.e., } \\
\text { limitations) }\end{array}$ \\
\hline $\begin{array}{l}\text { VII. Wilson, } \\
\text { MA, Journal of } \\
\text { the American } \\
\text { Dietetic } \\
\text { Association } \\
(\mathbf{2 0 0 2}), \text { US }\end{array}$ & $\begin{array}{l}265 \text { preceptors }(95.4 \% \\
\text { RDs) }\end{array}$ & $\begin{array}{l}\text { Convenience sample, } \\
\text { descriptive, relational } \\
\text { study, paper survey }\end{array}$ & $\begin{array}{l}\text { Preceptors' } \\
\text { perception of } \\
\text { their role }\end{array}$ & $\begin{array}{l}\text { Perception of role: confident in understanding } \\
\text { of role, includes variety of tasks/elements } \\
\text { (essential and non-essential) in the Preceptor } \\
\text { Typology (teacher, preceptor/teacher, } \\
\text { preceptor, preceptor/mentor, mentor), satisfied } \\
\text { with performance of their perceived } \\
\text { responsibilities. }\end{array}$ & $\begin{array}{l}\text { Limitations: } \\
\text { convenience sample, } \\
\text { lack of preceptor registry } \\
\text { to randomly select } \\
\text { sample, question if } \\
\text { preceptor typology } \\
\text { instrument validated. }\end{array}$ \\
\hline $\begin{array}{l}\text { VIII. Jay \& } \\
\text { Hoffman, } \\
\text { Journal of the } \\
\text { American } \\
\text { Dietetic } \\
\text { Association } \\
\text { (2000), } \\
\text { Michigan } \\
\end{array}$ & $\begin{array}{l}55 \text { preceptors from } \\
1 \text { university DI } \\
\text { program (mostly RDs; } \\
\text { settings: clinical, } \\
\text { community, } \\
\text { foodservice } \\
\text { management) }\end{array}$ & $\begin{array}{l}\text { Questionnaire, includes } \\
\text { subscales on opinions on } \\
\text { non-monetary benefits, } \\
\text { scales on individual/ } \\
\text { professional, } \\
\text { intradepartmental, and } \\
\text { interdepartmental } \\
\text { benefits }\end{array}$ & $\begin{array}{l}\text { Benefits of } \\
\text { serving as a } \\
\text { preceptor for DI, } \\
\text { focus intangible } \\
\text { benefits }\end{array}$ & $\begin{array}{l}\text { Agreed there are individual and departmental } \\
\text { benefits. Significant difference in responses of } \\
\text { foodservice and clinical for } \\
\text { individual/professional benefits, with clinical } \\
\text { preceptors rating benefits higher. All } \\
\text { respondents felt department broke even or } \\
\text { gained. }\end{array}$ & $\begin{array}{l}\text { Limitations: preceptors } \\
\text { from one dietetic } \\
\text { internship program, } \\
\text { small sample. }\end{array}$ \\
\hline $\begin{array}{l}\text { IX. Gilbride \& } \\
\text { Conklin, } \\
\text { Journal of the } \\
\text { American } \\
\text { Dietetic } \\
\text { Association } \\
\text { (1996), US }\end{array}$ & $\begin{array}{l}312 \text { dietitians from } 74 \\
\text { AP4s (97\% RDs) }\end{array}$ & $\begin{array}{l}\text { Questionnaire, } 2 \\
\text { instruments: program } \\
\text { directors, dietitians who } \\
\text { precept }\end{array}$ & $\begin{array}{l}\text { Benefits of } \\
\text { training students } \\
\text { in AP4s } \\
\text { compared to DIs, } \\
\text { Preceptor topics: } \\
\text { Intangible } \\
\text { benefits }\end{array}$ & $\begin{array}{l}\text { Strongest agreement between AP4s and DIs: } \\
\text { satisfaction of seeing students develop, } \\
\text { teaching students makes job more interesting, } \\
\text { sense of achievement. Agreed there are } \\
\text { intangible benefits for AP4 practice sites and } \\
\text { the professionals who work there. } \\
\text { Organizational benefits to department: } \\
\text { increased awareness of current research, } \\
\text { student project contributions. }\end{array}$ & \\
\hline $\begin{array}{l}\text { X. Conklin \& } \\
\text { Simko, Journal } \\
\text { of the American } \\
\text { Dietetic } \\
\text { Association } \\
\text { (1994), US }\end{array}$ & $\begin{array}{l}143 \text { Dietitians, } 155 \\
\text { interns }\end{array}$ & $\begin{array}{l}\text { Mail survey, } 3 \\
\text { instruments: } \\
\text { administrative, teaching } \\
\text { activity recording form, } \\
\text { learning activity } \\
\text { recording form }\end{array}$ & $\begin{array}{l}\text { Economic } \\
\text { benefits } \\
\text { associated with } \\
\text { DIs }\end{array}$ & $\begin{array}{l}\text { Departmental teaching time: mean } 37.3 \pm 18.8 \\
\mathrm{hr} / \mathrm{wk} \text { (range } 4.5 \text { to } 84.1 \mathrm{hr} / \mathrm{wk}) \text {, Student time } \\
\text { in independent professional activities: mean } \\
66.5 \pm 42.6 \mathrm{hr} / \mathrm{wk} \text { (range } 6.5 \text { to } 156.5 \mathrm{hr} / \mathrm{wk} \text { ), } \\
\text { net productivity: } 29.2 \pm 35.7 \mathrm{hr} / \mathrm{wk} \text {. }\end{array}$ & \\
\hline
\end{tabular}


Table 2.2

Literature Review-Precepting in Other Health-Related Fields

\begin{tabular}{|c|c|c|c|c|c|}
\hline $\begin{array}{l}\text { Author (year); } \\
\text { Health Field; } \\
\text { Location }\end{array}$ & $\begin{array}{c}\text { Final N, } \\
\text { Participants }\end{array}$ & Design, Instrument & $\begin{array}{c}\text { Main Study } \\
\text { Measures }\end{array}$ & Results Related to RQ & $\begin{array}{c}\text { Comments (i.e. } \\
\text { limitations) }\end{array}$ \\
\hline $\begin{array}{l}\text { Hall et al. (2015) } \\
\text { Physical } \\
\text { Therapists } \\
\text { (PTs), } \\
\text { Canada }\end{array}$ & $\begin{array}{l}3,148 \mathrm{PTs} \\
\text { participated (out of } \\
\mathrm{N}=18,110 \text { all } \\
\text { practicing Physical } \\
\text { Therapists) includes } \\
\text { supervising and } \\
\text { nonsupervising PTs } \\
\text { Covers all practice } \\
\text { areas, settings, and } \\
\text { geographical } \\
\text { regions. }\end{array}$ & $\begin{array}{l}\text { Web-based survey } \\
\text { sent out via e-mail } \\
\text { Survey covers } 4 \\
\text { constructs: personal } \\
\text { and professional, } \\
\text { context, evaluation, } \\
\text { and student }\end{array}$ & $\begin{array}{l}\text { To Supervise or Not } \\
\text { to Supervise a } \\
\text { Physical Therapist } \\
\text { Student: A National } \\
\text { Survey of Canadian } \\
\text { Physical Therapists } \\
\text { Benefits, barriers of } \\
\text { clinical education }\end{array}$ & $\begin{array}{l}\text { Results suggest a 6-factor structure } \\
\text { related to decision to supervise } \\
\text { students: } \\
\text { 1. Feelings of stress } \\
\text { 2. Student contribution to efficiency } \\
\text { of workplace } \\
\text { 3. Does not like assessment } \\
\text { instrument } \\
\text { 4. Preparation of clinical instructor } \\
\text { to evaluate } \\
\text { 5. Student attitude and preparation } \\
\text { 6. Professional responsibility and } \\
\text { role } \\
\text { Stress-most important influential } \\
\text { contributor to this decision. }\end{array}$ & $\begin{array}{l}\text { Strength: large sample size } \\
\text { covering all practice areas. } \\
\text { Limitation: specific to } \\
\text { Canada and PTs. }\end{array}$ \\
\hline $\begin{array}{l}\text { Hartzler et al. } \\
\text { (2015) } \\
\text { Pharmacy, } \\
\text { US }\end{array}$ & $\begin{array}{l}1,437 \text { pharmacy } \\
\text { preceptors and } \\
\text { residents } \\
\text { participated }\end{array}$ & $\begin{array}{l}\text { Survey: Preceptor } \\
\text { development in } \\
\text { participants' } \\
\text { program } \\
\text { Challenges and } \\
\text { weaknesses in } \\
\text { preceptor } \\
\text { development } \\
\text { Optimal incentives } \\
\text { for involving } \\
\text { preceptors in } \\
\text { development } \\
\text { activities }\end{array}$ & $\begin{array}{l}\text { Preceptor } \\
\text { development in } \\
\text { pharmacy residency } \\
\text { programs: current } \\
\text { status of, challenges, } \\
\text { directions for future } \\
\text { opportunities }\end{array}$ & $\begin{array}{l}\text { Results: } \\
\text { - Top } 5 \text { characteristics of effective } \\
\text { preceptors by residents } \\
\text { - } 88 \% \text { of preceptors felt they were } \\
\text { adequately trained as a preceptor } \\
\text { - } 51.5 \% \text { felt they had adequate time } \\
\text { for precepting residents } \\
\text { - Primary barrier to their development } \\
\text { as preceptors: lack of time } \\
\text { - } 60 \% \text { primary challenge: "effectively } \\
\text { precepting while meeting } \\
\text { employment responsibilities" }\end{array}$ & $\begin{array}{l}\text { Strength: large sample size. } \\
\text { Limitation: specific to } \\
\text { pharmacy preceptors. }\end{array}$ \\
\hline
\end{tabular}


Table 2.2 (continued)

\begin{tabular}{|c|c|c|c|c|c|}
\hline $\begin{array}{l}\text { Author (year); } \\
\text { Health Field; } \\
\text { Location }\end{array}$ & $\begin{array}{c}\text { Final N, } \\
\text { Participants }\end{array}$ & Design, Instrument & $\begin{array}{l}\text { Main Study } \\
\text { Measures }\end{array}$ & Results Related to RQ & $\begin{array}{l}\text { Comments (i.e. } \\
\text { limitations) }\end{array}$ \\
\hline $\begin{array}{l}\text { Blum (2014), } \\
\text { Nursing }\end{array}$ & $\begin{array}{l}34 \text { RN preceptors of } \\
\text { senior-level students } \\
\text { or novice nurses } \\
\text { enrolled } \\
28 \text { collected post- } \\
\text { intervention data }\end{array}$ & $\begin{array}{l}\text { Pre- and posttest (after } \\
\text { podcast and preceptor } \\
\text { experience) included: } \\
\text { - Commitment to } \\
\text { Preceptor Role Scale } \\
\text { - Preceptor's Perception } \\
\text { of Benefits Scale } \\
\text { - Preceptor's Perception } \\
\text { of Support Scale } \\
\text { Visual analog scale }\end{array}$ & $\begin{array}{l}\text { Evaluating } \\
\text { Preceptor } \\
\text { Perception of } \\
\text { Support Using } \\
\text { Educational } \\
\text { Podcasts } \\
\text { Effect of } \\
\text { educational podcasts } \\
\text { on preceptors' } \\
\text { commitment, } \\
\text { perception of } \\
\text { benefits, perception } \\
\text { of support. }\end{array}$ & $\begin{array}{l}\text { Results: } \\
\text { - Significant increase from pre- to } \\
\text { posttest in preceptor's perception } \\
\text { of support (greatest increase for } \\
\text { preceptors with less experience } \\
\text { precepting or less training) } \\
\text { - Strong correlation: preceptor's } \\
\text { perception of support and } \\
\text { commitment to role }\end{array}$ & $\begin{array}{l}\text { Limitations: small } \\
\text { sample size, specific to } \\
\text { nursing. }\end{array}$ \\
\hline $\begin{array}{l}\text { Natan et al. } \\
\text { (2014), } \\
\text { Nursing, } \\
\text { Israel }\end{array}$ & $\begin{array}{l}200 \text { Jewish women } \\
\text { born in Israel, } \\
\text { nurses working as } \\
\text { preceptors in } \\
\text { hospital and } \\
\text { community settings } \\
\text { Most full-time } \\
\text { employees } \\
\text { Working as } \\
\text { preceptors for } 4.7 \\
\text { yrs. Respondents } \\
\text { worked with nursing } \\
\text { students ( } 74 \%) \text { and } \\
\text { new nurses ( } 71 \%) \text {. } \\
\text { On average worked } \\
\text { with } 8.3 \text { preceptees } \\
\text { in previous } 6 \\
\text { months }\end{array}$ & $\begin{array}{l}\text { Convenience sample } \\
\text { Five-part questionnaire, } \\
\text { developed by Dibert and } \\
\text { Goldenberg (1995), } \\
\text { translated into Hebrew: } \\
\text { Preceptor's Perception of } \\
\text { Benefits and Rewards } \\
\text { (PPBR) Scale } \\
\text { Preceptor's Perception of } \\
\text { Support (PPS) Scale } \\
\text { Commitment to the } \\
\text { Preceptor Role (CPR) } \\
\text { Scale }\end{array}$ & $\begin{array}{l}\text { Commitment of } \\
\text { Israeli nursing } \\
\text { preceptors to the } \\
\text { role of preceptor }\end{array}$ & $\begin{array}{l}\text { Moderate commitment to preceptor } \\
\text { role. } \\
\text { Support within employment framework } \\
\text { and benefits and rewards found to be } \\
\text { related to commitment to preceptor role } \\
\text { (intrinsic benefits and rewards more } \\
\text { than extrinsic). } \\
\text { No correlation between: support } \\
\text { outside workplace, number of } \\
\text { preceptees in last } 6 \text { months, average } \\
\text { number of preceptees per session and } \\
\text { commitment. } \\
\text { Support within nurses' employment } \\
\text { framework-most important } \\
\text { contributing factor to commitment. }\end{array}$ & \\
\hline
\end{tabular}


Table 2.2 (continued)

\begin{tabular}{|c|c|c|c|c|c|}
\hline $\begin{array}{c}\text { Author (year); } \\
\text { Health Field; } \\
\text { Location } \\
\end{array}$ & $\begin{array}{c}\text { Final N, } \\
\text { Participants }\end{array}$ & Design, Instrument & $\begin{array}{l}\text { Main Study } \\
\text { Measures }\end{array}$ & Results Related to RQ & $\begin{array}{l}\text { Comments (i.e. } \\
\text { limitations) }\end{array}$ \\
\hline $\begin{array}{l}\text { O'Brien et al. } \\
\text { (2014) } \\
\text { Nursing, } \\
\text { Midwifery } \\
\text { Hunter New } \\
\text { England Local } \\
\text { Health District } \\
\text { (HNELHD), } \\
\text { New South Wales } \\
\text { (NSW) }\end{array}$ & $\begin{array}{l}337 \text { respondents } \\
\text { included Registered } \\
\text { Nurses (RNs), } \\
\text { Registered } \\
\text { Midwives, and } \\
\text { Enrolled Nurses } \\
\text { (ENs) } \\
\text { Conducted in } 9 \\
\text { public acute care } \\
\text { hospitals in the } \\
\text { HNELHD in NSW } \\
\text { Invited: Nurses and } \\
\text { midwives who } \\
\text { precept } \\
\text { undergraduate } \\
\text { students }\end{array}$ & $\begin{array}{l}\text { Descriptive cross- } \\
\text { sectional multisite survey } \\
\text { Clinical Preceptor } \\
\text { Experience Evaluation } \\
\text { Tool (CPEET) used, } 4 \\
\text { subscales: measuring } \\
\text { opinion of preceptor's } \\
\text { role, satisfaction, } \\
\text { experience and education, } \\
\text { and challenges } \\
\text { Surveys-hand-delivered } \\
\text { by research team to } \\
\text { nursing unit manager in } \\
\text { each ward }\end{array}$ & $\begin{array}{l}\text { Evaluating the } \\
\text { preceptor role for } \\
\text { pre-registration } \\
\text { nursing and } \\
\text { midwifery student } \\
\text { clinical education. } \\
\text { Evaluate preceptors' } \\
\text { perceptions in } \\
\text { relations to their } \\
\text { roles, experience, } \\
\text { challenges, and } \\
\text { satisfaction }\end{array}$ & $\begin{array}{l}\text { Majority scored high on all } 4 \text { subscales; they } \\
\text { were generally satisfied with the role of } \\
\text { precepting. } \\
\text { Preceptors were less satisfied when it turned } \\
\text { out to be time-consuming and challenges } \\
\text { arose with difficult or unmotivated students. } \\
36 \% \text { of respondents had undertaken } \\
\text { education preparation for teaching, } \\
\text { supervising, or precepting undergraduate } \\
\text { students. } \\
\text { Differences observed in: } \\
\text { - preceptors who had training in precepting } \\
\text { in three of the subscales (challenges, } \\
\text { experience and education, and satisfaction). } \\
\text { - preceptors with access to university-trained } \\
\text { and paid facilitators on the ward (61\% of the } \\
\text { preceptors) scored higher in all } 4 \text { domains } \\
\text { and "were significantly more satisfied with } \\
\text { their role." }\end{array}$ & \\
\hline $\begin{array}{l}\text { Latessa el al. } \\
(\text { 2013) } \\
\text { Community } \\
\text { Preceptors of } \\
\text { Health } \\
\text { Professions } \\
\text { Students, } \\
\text { North Carolina }\end{array}$ & $\begin{array}{l}1,278 \text { completed } \\
\text { survey } \\
\text { Survey distributed } \\
\text { to } 2,359 \\
\text { community-based } \\
\text { primary care } \\
\text { preceptors } \\
\text { (pharmacists, } \\
\text { physicians, } \\
\text { physician assistants, } \\
\text { advanced practice } \\
\text { nurses) }\end{array}$ & $\begin{array}{l}\text { Survey: } \\
\text { Satisfaction, motivations, } \\
\text { and value on teaching }\end{array}$ & $\begin{array}{l}\text { Satisfaction, } \\
\text { Motivation, and } \\
\text { Future of } \\
\text { Community } \\
\text { Preceptors: What } \\
\text { Are the Current } \\
\text { Trends }\end{array}$ & $\begin{array}{l}\text { Importance of reasons to precept, top } 5 \\
\text { 1. Giving back to profession }(99.4 \%) \\
\text { 2. Demonstrating community practice } \\
\quad(99 \%) \\
\text { 3. Intellectual stimulation }(98.7) \\
\text { 4. Enjoyment of teaching }(98.5 \%) \\
\text { 5. Being a role model }(87.9 \%) \\
\text { Satisfaction with precepting was high, } 91.7 \% \\
\text { of respondents were satisfied } \\
\text { 88.7\% anticipated will continue to precept } \\
93.7 \% \text { satisfied overall with professional life }\end{array}$ & $\begin{array}{l}\text { Limitations: } \\
\text { limited around } \\
\text { preceptor } \\
\text { satisfaction, lacked } \\
\text { additional detail } \\
\text { about the small } \\
\text { group that } \\
\text { responded } \\
\text { negatively, did } \\
\text { not include } \\
\text { nonpreceptors. } \\
\text { Strength: large } \\
\text { sample size. }\end{array}$ \\
\hline
\end{tabular}


Table 2.2 (continued)

\begin{tabular}{|c|c|c|c|c|c|}
\hline $\begin{array}{c}\text { Author (year); } \\
\text { Health Field; } \\
\text { Location }\end{array}$ & $\begin{array}{c}\text { Final N, } \\
\text { Participants }\end{array}$ & Design, Instrument & $\begin{array}{c}\text { Main Study } \\
\text { Measures }\end{array}$ & Results Related to RQ & $\begin{array}{l}\text { Comments (i.e. } \\
\text { limitations) }\end{array}$ \\
\hline $\begin{array}{l}\text { Skrabal et al. } \\
(2010) \\
\text { Pharmacy } \\
\text { Effects of } \\
\text { Region, Practice } \\
\text { Setting, and } \\
\text { Population } \\
\text { Density on } \\
\text { Responses }\end{array}$ & $\begin{array}{l}\text { Convenience } \\
\text { sample: } 1,130, \\
\text { survey sent to } 4,396 \\
\text { APPE volunteer } \\
\text { preceptors } \\
\text { associated with } 9 \\
\text { schools or colleges } \\
\text { of pharmacy } \\
\text { (could not be faculty } \\
\text { or paid by the } \\
\text { university) }\end{array}$ & $\begin{array}{l}\text { National survey of } \\
\text { volunteer pharmacy } \\
\text { preceptors } \\
\text { Focused on experiential } \\
\text { load or number of slots of } \\
\text { students' rotations, time } \\
\text { commitment, and } \\
\text { compensation }\end{array}$ & $\begin{array}{l}\text { National Survey of } \\
\text { Volunteer Pharmacy } \\
\text { Preceptors: Effects } \\
\text { of Region, Practice } \\
\text { Setting, and } \\
\text { Population Density } \\
\text { on Responses }\end{array}$ & $\begin{array}{l}\text { Results: Hospital preceptors accepted students } \\
\text { from more schools, had more requests, turned } \\
\text { away more students, and spent less time with } \\
\text { students compared to other practice settings. } \\
\text { Urban sites took more students and turned } \\
\text { away more students than rural sites. } \\
\text { Rural sites spent less time with students but felt } \\
\text { they were spending adequate time for a quality } \\
\text { experience compared to other preceptors. } \\
\text { Regionally, West disagreed more (than } \\
\text { Midwest and South) that they had adequate } \\
\text { time to spend with students. } \\
\text { West required compensation less often } \\
\text { compared to Northeast and South. }\end{array}$ & $\begin{array}{l}\text { Limitation: } \\
\text { convenience } \\
\text { sample. } \\
\text { Strength: large } \\
\text { sample size. }\end{array}$ \\
\hline $\begin{array}{l}\text { Hyrkas \& } \\
\text { Shoemaker } \\
(2007)\end{array}$ & $\begin{array}{l}82 \text { preceptors } \\
\text { (precepting } \\
\text { undergraduate } \\
\text { students, } \mathrm{n}=55 ; \\
\text { working with newly } \\
\text { hired nurses, } \mathrm{n}=27 \text { ) } \\
80.5 \% \text { of all } \\
\text { respondents } \\
\text { attended } \\
\text { preceptorship } \\
\text { workshops }\end{array}$ & $\begin{array}{l}\text { Convenience Sample } \\
\text { Paper Questionnaires } \\
\text { Designed as a duplication } \\
\text { of work done by Dibert } \\
\text { and Goldenberg (1995) } \\
\text { and Usher et al. (1999) } \\
\text { Four questionnaires used: } \\
\text { 1.Preceptor's Perceptions } \\
\text { of Benefits and Rewards } \\
\text { (PPBR) Scale } \\
\text { 2.Preceptor's Perceptions } \\
\text { of Support (PPS) Scale } \\
\text { 3.Commitment to the } \\
\text { Preceptor Role (CPR) } \\
\text { Scale } \\
\text { 4.Demographic info sheet }\end{array}$ & $\begin{array}{l}\text { Changes in the } \\
\text { preceptor role: } \\
\text { revisiting } \\
\text { preceptors' } \\
\text { perceptions of } \\
\text { benefits, rewards, } \\
\text { supports, and } \\
\text { commitment to the } \\
\text { role }\end{array}$ & $\begin{array}{l}\text { Report findings similar to those from earlier } \\
\text { studies, but there were some differences } \\
\text { between the two groups. } \\
\text { Positive correlation between preceptors } \\
\text { working with nursing students and perceptions } \\
\text { of support. } \\
\text { Perceptions of support increased with age, time } \\
\text { since graduation, and years of experience. } \\
\text { Higher perceptions of benefits and rewards } \\
\text { found compared to earlier studies. } \\
\text { Lower perceptions of support compared to an } \\
\text { earlier Canadian study. } \\
\text { High commitment to the role continued. }\end{array}$ & $\begin{array}{l}\text { Limitations: small } \\
\text { convenience } \\
\text { sample, response } \\
\text { rate low, overall } \\
36.3 \% \text {. } \\
\text { Confirmed } \\
\text { preceptors are } \\
\text { committed, and } \\
\text { even more so when } \\
\text { benefits are } \\
\text { present. } \\
\text { Preceptors require } \\
\text { continuous } \\
\text { support. }\end{array}$ \\
\hline
\end{tabular}


Table 2.2 (continued)

\begin{tabular}{|c|c|c|c|c|c|}
\hline $\begin{array}{c}\text { Author (year); } \\
\text { Health Field; } \\
\text { Location }\end{array}$ & $\begin{array}{c}\text { Final N, } \\
\text { Participants }\end{array}$ & Design, Instrument & $\begin{array}{l}\text { Main Study } \\
\text { Measures }\end{array}$ & Results Related to RQ & $\begin{array}{l}\text { Comments (i.e. } \\
\text { limitations) }\end{array}$ \\
\hline $\begin{array}{l}\text { Usher et al. } \\
\text { (1999) } \\
\text { North } \\
\text { Queensland, } \\
\text { Australia } \\
\text { Nursing }\end{array}$ & $\begin{array}{l}\text { Convenience } \\
\text { sample: } \\
\text { - } 134 \text { nurse } \\
\text { preceptors in } \\
\text { undergraduate } \\
\text { nursing course } \\
\text { - } 105 \text { (78\% return } \\
\text { rate) } \\
\text { - Mostly female } \\
\text { - Large number } \\
\text { novice } \\
\text { preceptors } \\
\text { - } 46 \% \text { attended a } \\
\text { preceptor } \\
\text { workshop }\end{array}$ & $\begin{array}{l}\text { Replication of research } \\
\text { (Canada) by Dibert and } \\
\text { Goldenberg (1995) } \\
\text { Four-part questionnaire } \\
\text { mailed: } \\
\text { 1. Preceptor's Perception } \\
\text { of Benefits and Rewards } \\
\text { (PPBR) Scale } \\
\text { 2. Preceptor's Perception } \\
\text { of Support (PPS) Scale } \\
\text { 3. Commitment to } \\
\text { Preceptor Role (CPR) } \\
\text { Scale } \\
\text { 4. Demographic section }\end{array}$ & $\begin{array}{l}\text { An exploration of } \\
\text { the preceptor role: } \\
\text { preceptors' } \\
\text { perception of } \\
\text { benefits, rewards, } \\
\text { supports, and } \\
\text { commitment to the } \\
\text { preceptor role }\end{array}$ & $\begin{array}{l}\text { Results: } \\
\text { Strong commitment to preceptor role when } \\
\text { perceived both material and nonmaterial } \\
\text { benefits in the role. } \\
\text { Positive association between support from } \\
\text { coworkers and the institution and importance of } \\
\text { partaking in precepting. } \\
\text { Indications for more support from hospital- } \\
\text { based educators. } \\
\text { Less support by coworkers and institution in } \\
\text { North Queensland than in Canada study. }\end{array}$ & $\begin{array}{l}\text { Limitations: small } \\
\text { sample size (but } \\
\text { larger than the } \\
\text { Canada study } \\
\text { replicated), } \\
\text { participants with } \\
\text { little experience. } \\
\text { Results noted to } \\
\text { mostly parallel } \\
\text { Dibert and } \\
\text { Goldenberg }\end{array}$ \\
\hline $\begin{array}{l}\text { Dibert \& } \\
\text { Goldenberg } \\
\text { (1995) } \\
\text { Canadian } \\
\text { Preceptors } \\
\text { Nursing }\end{array}$ & $\begin{array}{l}59 \text { nurse preceptors } \\
\text { in a } 400 \text {-bed } \\
\text { teaching hospital } \\
\text { (urban) }\end{array}$ & $\begin{array}{l}\text { Convenience Sample } \\
\text { Descriptive correlational } \\
\text { study } \\
\text { Four-part questionnaire: } \\
\text { 1. Preceptor's Perception } \\
\text { of Benefits and Rewards } \\
\text { (PPBR) Scale } \\
\text { 2. Preceptor's Perception } \\
\text { of Support (PPS) Scale } \\
\text { 3. Commitment to } \\
\text { Preceptor Role (CPR) } \\
\text { Scale } \\
\text { 4. Demographics } \\
\text { (Kanter's } 1977 \text { model) }\end{array}$ & $\begin{array}{l}\text { Preceptors' } \\
\text { perceptions of } \\
\text { benefits, rewards, } \\
\text { supports, and } \\
\text { commitment to the } \\
\text { preceptor role }\end{array}$ & $\begin{array}{l}\text { Commitment to preceptor role positively } \\
\text { associated with: } \\
\text { - perception of benefits and rewards } \\
\text { - } \quad \text { perception of support } \\
\text { - number of preceptor experiences. }\end{array}$ & $\begin{array}{l}\text { Limitation: small } \\
\text { convenience } \\
\text { sample. } \\
\text { Implications: for } \\
\text { nursing educators } \\
\text { and administrators, } \\
\text { ensuring adequate } \\
\text { benefits, rewards } \\
\text { and support } \\
\text { available. } \\
\text { Recommendations: } \\
\text { developing more } \\
\text { preceptor programs } \\
\text { that are more } \\
\text { effective }\end{array}$ \\
\hline
\end{tabular}




\section{Summary of Rationale and Research Questions}

There is a limited number of volunteer preceptors for qualified dietetic students (ACEND, 2013). The published research on the benefits, barriers, motivators/incentives, support, satisfaction, and factors associated with commitment to the preceptor role in dietetics is dated and limited in scope and demographics. Most of the studies are small in number, lack randomization of participants, and have minimally included nonpreceptors as participants. The purpose of this study was to have a better national understanding of RDNs who precept, are former preceptors, or have never precepted; the reason(s) dietitians precept; the training and support they receive; their perception of benefits, motivators/incentives, and barriers to precepting; as well as their satisfaction with precepting and factors related to commitment to the preceptor role.

RQ1: What incentivizes or motivates RDNs currently in the preceptor role to precept? What would motivate more RDNs to take on the preceptor role?

RQ2: What are the barriers to precepting for RDNs?

RQ3: What are the RDNs' perceived benefits, support, satisfaction, and commitment to the preceptor role?

RQ4: What factors are associated with RDNs being current preceptors? 
Chapter III

METHODS

This chapter describes the study design, methods and data analysis plan. It also describes the development of the survey and pilot study to examine psychometrics.

\section{Study Design}

This was a cross-sectional study of a nationally representative sample of Registered Dietitian Nutritionists (RDNs) to understand more about RDNs who precept as well as those who are not precepting, and the benefits, support, motivators/incentives, satisfaction, and barriers to precepting; and to determine factors associated with commitment to the preceptor role. The study was approved by the Institutional Review Board (IRB) at Teachers College, Columbia University (protocol ID 16-276, 3/30/2016).

\section{Setting and Participants}

The study was conducted online through Teachers College, Columbia University. Inclusion criteria required that participants be RDNs registered in the United States through the Commission on Dietetics Registration (CDR). Participants were eligible if they were current preceptors $(\leq 1$ year prior), past preceptors $(>1$ year prior), or had never precepted for a U.S.-accredited dietetic internship program(s). Exclusion criteria 
included the current investigator, any RDNs who participated in the pilot study, and any RDNs who provided feedback on the survey during the development phase.

\section{Sampling and Enrollment}

Enrollment began Friday, October 12, 2018 at 9:01 a.m. EDT and continued through December 2018. Participants were recruited from a list of RDNs registered with the CDR, the credentialing agency for the Academy of Nutrition and Dietetics (AND). As of April 12, 2016, the list included 90,728 RDNs. Names, cities, states, zip codes, country (all USA), and e-mail addresses were obtained for all RDNs through the CDR appeal process in order to receive more than the cap of 2,500 names. Among the 90,728, the current investigator was excluded ( $\mathrm{n}=1), 39$ RDNs were excluded due to participation in the pilot study ( $\mathrm{n}=39)$, and 27 RDNs were removed from the list since they provided feedback on or assisted in some way in reviewing the survey during the development phase. Among the 90,728 RDNs, a random list of $10 \%(n=9,066)$ of the 90,663 was generated. All 90,663 RDNs were assigned a random number between 0 and 1 using the RAND function in Excel. Once all RDNs had a random number in the column next to the data, the column was sorted in ascending order and the first 9,066 RDNs in the list made up the randomly selected sample. This subset of 9,066 RDNs was sent an e-mail asking about their interest and participation in the survey. The e-mail included an online link to the survey. A reminder e-mail was sent out on Monday, October 29, 2018 at 7:56 a.m. EDT; to further increase the response rate, a second reminder e-mail was added and sent out on Tuesday, November 27, 2018 at 9:09 a.m. EST. Participants who completed the survey were entered into a raffle to receive a $\$ 40$ gift card ( 1 in 272 chance of winning assuming a participation rate of $\sim 15 \%)$. 
The RDNs who completed the survey were asked a question at the end of the survey if they would be willing to complete the survey again 1 to 3 weeks later for test/ retest reliability. Those who answered yes were automatically set up in Qualtrics to be resent the survey (with the exception of the consent question and the question about taking the retest) via e-mail approximately 1 week after completion. The goal for the retest was to receive at least 30 respondents in each group (current, former, and never), preferably with about a 1-week time in between. The former and current groups met this goal; however, the never group of respondents was sent a reminder e-mail to increase the retest response rate from the group and ensure a greater number of the respondents retaking the survey in about a week's timeframe. Survey responses were reviewed for completeness and time between the first and second survey responses taken into consideration.

\section{Data Collection}

Data were collected using the TC Qualtrics secure and privacy-protected online survey software system. Subject information was kept confidential and responses were kept in password-protected files and password-protected computers. In Qualtrics, individual survey respondents were given a random alpha/numeric response ID. The survey was not anonymous since it was necessary to have identifiers to link for test/ retest reliability and to prevent participants from taking the survey more than once or sharing with others.

Participants who were interested and eligible provided consent prior to starting the survey. The survey software was programmed to only allow those who chose "I 
agree" to the consent statement to continue. If they did not agree, the survey ended (see Appendix K for Consent Form).

\section{Pilot Study}

Pilot participants were recruited through a randomly selected national sample of Registered Dietitians (RDs) and Registered Dietitian Nutritionists (RDNs) (RD = RDN) employed with Sodexo. Sodexo provides contracted (or outsourced) quality of life services and is reported to be the single largest private employer of RDNs in the United States. Sodexo RDNs work in various areas of the field, including educational settings from preschool through college, health care facilities, senior living communities, corporations, and more. RDNs working with Sodexo may currently precept, be former preceptors, or may have never precepted a dietetic intern over their career; therefore, this was the population chosen to use for this pilot.

The pilot included the distribution of an online survey related to the RQs to a randomly selected (convenience) sample of RDNs, using TCs Qualtrics Survey Software. Participants were chosen randomly from a Sodexo list of 1,834 RDNs. E-mails were sent in batches of 100 until 30 surveys were reached. The e-mails were numbered 1 to 1,834 and a random number generator was used to randomly choose the e-mail distribution lists. Two batches (200 e-mails) were sent ( 7 e-mails bounced back). Each RDN received a communication invite via e-mail regarding participation in the pilot study, which included an online link to the questionnaire. A reminder e-mail was also sent out 1 to 2 weeks after the initial e-mail as a reminder to complete the survey and to increase the response rate. 
RDNs who completed the survey were also asked to complete the survey again 1 to 3 weeks later for test-retest reliability; this information was also included in the initial e-mail. Once TC IRB approval was obtained for this pilot (approved August 19, 2015, protocol ID 15-387), the Sodexo Senior Director of Nutrition and Patient/Resident Services was informed and the pilot survey was approved for use prior to its distribution. The pilot e-mail, consent, and RD/N Survey used for the pilot are in Appendices A-F.

Pilot data responses (including retest) were reviewed in TC Qualtrics and exported to Excel and SPSS for further reliability analysis. Thirty-nine RDNs participated in the first survey of the pilot and 16 of the 39 RDNs completed the retest survey. Of those 16,10 were current preceptors, 4 were former preceptors, and 2 never precepted. Due to the low number of retest respondents in each group in the pilot as well as time restraints on conducting another pilot and preventing further removal of RDNs from the national list, the main survey has a retest component.

The online questionnaire, reliability, validity. A 45-59 item online questionnaire (varied based on preceptor status and survey responses) was developed and informed by the literature review; communication with RDNs, DI preceptors/ nonpreceptors; Teachers College, Columbia University’s research/dissertation seminar professors and graduate students (panel of experts); a TC, CU RD research scientist; and Directors/Coordinators of dietetic internship programs in the United States. Questions were also adapted from previous instruments. CDR preceptor training discussion forum responses from a question posted related to barriers and motivators to precepting were also reviewed. The investigator's area of expertise/experience also included working as 
an RDN and DI preceptor for over 10 years. The questionnaire included closed- and open-ended items.

Three of the scales used in the questionnaire were adapted from the nursing literature, the Preceptor's Perception of Support (PPS) scale, Commitment to the Preceptor Role (CPR) scale, and the Preceptor's Perception of Benefits and Rewards (PPBR) scale. Reliability of these scales was noted to be reported by Dibert and Goldenberg (1995), Hyrkas and Shoemaker (2007), and Natan, Qeadan, and Egbaria (2014). Internal consistency reliability was calculated using the Cronbach's alpha coefficient for each scale with the responses of the first distribution of the online pilot survey ( $\mathrm{n}=39$; note that not all questions were asked of all); Cronbach's alpha for the slightly modified version of these three scales ranged from 0.874 to 0.907 . Cronbach's alpha for each scale are included in the description of the scale under the measures section that follows.

Intraclass correlation coefficients (ICCs) were computed using SPSS for continuous data to evaluate test-retest reliability and ICCs were assessed using the following scale: "excellent" $=\geq 0.81$, "good" $=0.61-0.80, "$ moderate" $=0.41-0.60$, “poor" $=\leq 0.40$ (Singh et al., 2011). Items with poor ICCs were removed or modified. Reliability and validity were also assessed through the online pilot survey and the testretest data $(n=39, n$ at retest $=16$ : current $=10$, former $=4$, never $=2)$. Percent agreement assessment of test-retest responses due to the low numbers of respondents was also determined. Percent agreement cutoffs followed this scale: "excellent" $=90-100 \%$, $"$ good" $=75-89 \%$, "moderate" $=60-74 \%$, "poor" $=<60 \%$ (Singh et al., 2011). Items with poor percent agreement were removed or modified and those with moderate percent 
agreement were reviewed for possible modification to clarify the question or response options. For those with Likert scale-type responses, percent directional agreement was also reviewed following the same scale.

ICCs ranged from $\sim 0.118-1.0(\mathrm{p}<0.001)$. Percent agreement results of pilot testretest data ranged from $36.1 \%$ to $100 \%$ and percent directional agreement ranged from $29.0 \%$ to $100 \%$.

Questions and responses from current preceptors and those questions that crossed over for all three groups of respondents were able to be evaluated more for validity and reliability; however, due to the small number of former and never respondents and given that certain questions did not cross through all three groups, a retest was conducted of the main study survey for further reliability validation. See Table 3.1, Changes in Survey From Pilot to Main Study for Current Preceptors; Table 3.2, Changes in Survey From Pilot to Main Study for Former Preceptors; and Table 3.3, Changes in Survey From Pilot to Main Study for Never Precepted.

After the pilot, and in conjunction with the main survey, a test-retest was conducted to assess the reliability of the instrument. There were 217 respondents who started the retest, with 213 respondents answering Question 4 (required) regarding preceptor status. Of these, $88(41 \%)$ were current preceptors, 64 (30\%) former preceptors, and $61(28 \%)$ never precepted. Of these, 162 completed at least one scale in the retest. Test-retest reliability was assessed for each scale using Cronbach's alpha, evaluating for a recommended minimum level of .7 (Pallant, 2016, p. 6). The scales adapted from the nursing literature met the minimum; benefits scale was $.726(\mathrm{~N}=162)$, commitment .822 $(\mathrm{N}=151)$, support $.789(\mathrm{~N}=144)$, and satisfaction $.757(\mathrm{~N}=144)$. 
Table 3.1

Changes in Survey From Pilot to Main Study for Current Preceptors

\begin{tabular}{|c|c|c|c|}
\hline Constructs & Initial Survey & $\begin{array}{r}\text { Final Survey } \\
\end{array}$ & Comments \\
\hline $\begin{array}{l}\text { Demographics } \\
\text { Same all } 3 \text { groups of } Q \text { 's }\end{array}$ & $\begin{array}{l}\text { Age, gender, ethnicity/race, } \\
\text { geographic location, highest level of } \\
\text { education }\end{array}$ & $\begin{array}{l}\text { No questions added or removed } \\
\text { Question modifications: } \\
\text {-separated transgender and other to be } 2 \\
\text { different options in addition to female/male. }\end{array}$ & $\begin{array}{l}\text {-modification made secondary to } \\
\text { transgender webinar discussing lack } \\
\text { of data secondary to not having } \\
\text { specific transgender data. }\end{array}$ \\
\hline $\begin{array}{l}\text { Dietetics/job-related } \\
\text { In final all Qs same except } \\
\text { primary practice } Q \text {, not in } \\
\text { current preceptor } Q s\end{array}$ & $\begin{array}{l}\text { Registration, credentials, if working } \\
\text { in field of nutrition/dietetics, years } \\
\text { in current/most recent position, } \\
\text { years in field, primary practice area, } \\
\text { professional memberships (AND, } \\
\text { NDEP DPG), leadership positions, } \\
\text { teaching }\end{array}$ & $\begin{array}{l}\text { Questions removed: } \\
\text {-primary practice area } \\
\text { Questions added: } \\
\text {-asked if are a DI Director or Coordinator and } \\
\text { in responses also included if no but work with } \\
\text { an internship program to specify position /role } \\
\text {-if responded currently hold or previously held } \\
\text { a leadership position, asked to specify setting } \\
\text { Question modifications: } \\
\text {-if working in field of nutrition/dietetics added } \\
\text { response options to include if full-time, part- } \\
\text { time, per diem, or other } \\
\text {-nutrition/dietetics program response option } \\
\text { added to Q-if teaching outside of preceptor } \\
\text { role, indicate capacity } \\
\text {-Q on if have held a professional leadership } \\
\text { position modified to include in the field of } \\
\text { nutrition/dietetics }\end{array}$ & $\begin{array}{l}\text {-removed since have Q on rotation } \\
\text { precepting during so not to duplicate } \\
\text { and for sake of time } \\
\text {-questions added based on responses } \\
\text { in survey and based on expert } \\
\text { opinion; responses may also be } \\
\text { different for those who work with DI } \\
\text { programs } \\
\text {-decided to add secondary to what } \\
\text { read in other research articles, so can } \\
\text { see if difference in responses } \\
\text {-in the field of nutrition/dietetics } \\
\text { added to make question clearer to } \\
\text { reader } \\
\text {-modified to specify }\end{array}$ \\
\hline
\end{tabular}


Table 3.1 (continued)

\begin{tabular}{|c|c|c|c|}
\hline Constructs & Initial Survey & Final Survey & Comments \\
\hline $\begin{array}{l}\text { Preceptor-related } \\
\text { (includes training) }\end{array}$ & $\begin{array}{l}\text { Preceptor status (current, former, } \\
\text { never), years as a DI preceptor, total } \\
\text { number of DIs precepted over } \\
\text { career, typical number of interns } \\
\text { precept yearly, how many DI } \\
\text { programs precepted from in past } \\
\text { year, if have more than } 1 \text { intern at } \\
\text { same time, preceptor training }\end{array}$ & $\begin{array}{l}\text { Questions removed: } \\
\text { - if have more than } 1 \text { intern at same time } \\
\text { - how many DI programs precepted from in } \\
\text { past year } \\
\text { No questions added. } \\
\text { Question modifications: } \\
\text { - preceptor status question: 'or' removed from } \\
\text { current preceptor line to clarify meaning } \\
\text { interpreted same, minor modification to order } \\
\text { of former preceptor response (same words) } \\
\text {-preceptor training Q response options } \\
\text { modified: removed 'Yes, CDR's Free Online } \\
\text { Preceptor Training' since would also be } \\
\text { included in another response 'Yes, formal } \\
\text { training (i.e., class, online course)'; also added } \\
\text { to 'Do not remember' response 'or do not know } \\
\text { if would consider training' }\end{array}$ & $\begin{array}{l}\text { - expert opinion, do not need to } \\
\text { answer RQs, needed to decrease } \\
\text { length of survey } \\
\text { - also ask similar Qs: years } \\
\text { served as preceptor and number } \\
\text { of interns precept per year } \\
\text {-to clarify } \\
\text {-so response options read in } \\
\text { similar way } \\
\text {-to decrease overlap in } \\
\text { interpretation of response } \\
\text { options }\end{array}$ \\
\hline
\end{tabular}


Table 3.1 (continued)

\begin{tabular}{|c|c|c|c|}
\hline Constructs & Initial Survey & Final Survey & Comments \\
\hline Rotation-related & $\begin{array}{l}\text { If precepting required and/or } \\
\text { allowed, who makes final decision } \\
\text { to precept, involvement in the final } \\
\text { decision to precept, average number } \\
\text { of weeks } 1 \text { intern rotates, } \\
\text { hours/week intern under your } \\
\text { supervision, if are primary } \\
\text { preceptor, during which rotation } \\
\text { primarily precept, how many } \\
\text { hours/day intern under supervision, } \\
\text { if other RDNs regularly scheduled } \\
\text { to precept during the same rotation }\end{array}$ & $\begin{array}{l}\text { Questions removed: } \\
\text {-who makes final decision to precept } \\
\text { No Questions added. } \\
\text { Question modifications: } \\
\text { - hours per week intern under your supervision } \\
\text { changed to hours/week on a typical week each intern } \\
\text { is assigned to you } \\
\text {-during which rotation primarily precept question } \\
\text { and instructions reworded and in response options } \\
\text { order of medical nutrition therapy outpatient changed } \\
\text { to outpatient-medical nutrition therapy and order of } \\
\text { medical nutrition therapy inpatient also changed to } \\
\text { inpatient-medical nutrition therapy and examples } \\
\text { added to clarify (i.e., hospital, long-term care, rehab) } \\
\text { and order of. Also combined outpatient and } \\
\text { community responses and removed specialty option. } \\
\text {-question on in current position serving as a } \\
\text { preceptor is, changed to also include or most recent } \\
\text { position } \\
\text {-question on average number of weeks intern rotates } \\
\text { with preceptor during internship changed to typical } \\
\text { number of weeks } 1 \text { intern rotates (or is assigned to) } \\
\text { you during their rotation } \\
\text {-question on when you have a dietetic intern hours } \\
\text { per week each intern assigned to you modified to } \\
\text { include on a typical week and made less wordy }\end{array}$ & $\begin{array}{l}\text {-not needed, kept Q on } \\
\text { participant's involvement in final } \\
\text { decision to precept or not, expert } \\
\text { opinion } \\
\text {-to clarify and no longer need } \\
\text { number for CPE approval (since } \\
\text { approved) } \\
\text {-to clarify per pilot responses and } \\
\text { expert opinion }\end{array}$ \\
\hline
\end{tabular}


Table 3.1 (continued)

\begin{tabular}{|c|c|c|c|}
\hline $\begin{array}{c}\text { Constructs } \\
\end{array}$ & $\begin{array}{r}\text { Initial Survey } \\
\end{array}$ & Final Survey & Comments \\
\hline $\begin{array}{l}\text { Time conducting } \\
\text { activities_-precepting }\end{array}$ & $\begin{array}{l}\text { Minutes/day spend with intern in } \\
\text { certain activities conducting while } \\
\text { precepting }\end{array}$ & All questions removed from this section & $\begin{array}{l}\text {-changes made based on change to } \\
\text { policies, new: approval for } \\
\text { preceptors to receive continuing } \\
\text { education for the act of precepting } \\
\text { (2017) }\end{array}$ \\
\hline Benefits & $\begin{array}{l}\text { Perceived Benefits Scale, Benefits } \\
\text { received }\end{array}$ & $\begin{array}{l}\text { No questions added or removed. } \\
\text { Question modifications: } \\
\text {-question asking if received any of the } \\
\text { following benefits for precepting changed from } \\
\text { including timeframe of in past year to including } \\
\text { no timeframe and just asking if ever received } \\
\text { any of the following for precepting; same } \\
\text { question on if received any of the following } \\
\text { listed for precepting, } 3 \text { options for 'other' } \\
\text { decreased to 2, peer added to public recognition } \\
\text { option, CPEU opportunities changed to } \\
\text { offerings and clarified (not including for } \\
\text { precepting itself) }\end{array}$ & $\begin{array}{l}\text { Note: 4-point Likert scale used in } \\
\text { pilot and changed to 6-point in main } \\
\text {-expert opinion } \\
\text {-per difference in purpose of pilot } \\
\text { and to clarify }\end{array}$ \\
\hline
\end{tabular}


Table 3.1 (continued)

\begin{tabular}{|c|c|c|c|}
\hline Constructs & Initial Survey & Final Survey & Comments \\
\hline $\begin{array}{l}\text { Motivators/incentives, } \\
\text { Reason(s) precept }\end{array}$ & $\begin{array}{l}\text { Motivators would make more } \\
\text { likely to precept, why first } \\
\text { became preceptor, why } \\
\text { continue to precept }\end{array}$ & $\begin{array}{l}\text { Questions removed: } \\
\text {-why first became preceptor } \\
\text {-ranking of incentives question removed } \\
\text { No questions added. } \\
\text { Question modifications: } \\
\text {-why continue to precept multiple choice Q changed to 6-point } \\
\text { Likert scale-type question, asking to respond to 'Reason(s) I } \\
\text { precept...'; multiple-choice response options changed to } 11 \\
\text { statements and } 1 \text { other statement, statement on 'relationship } \\
\text { with Dietetic Internship Director' wording clarified to 'My } \\
\text { relationship with the Dietetic Internship Program/Director' } \\
\text {-in incentives question added that would make more likely to } \\
\text { precept (or precept more often), DPG abbreviation added, } \\
\text { response option for official designation/title for being a } \\
\text { preceptor added, example of what access to library resources } \\
\text { means added, CPEU option opportunities changed to offerings } \\
\text { and specified (not including for precepting itself), expenses } \\
\text { paid changed to expenses paid/reduced cost to attend a national } \\
\text { conference, peer added to public recognition response and gift } \\
\text { card included with pay/compensation response, CDR } \\
\text { membership changed to fee paid } \\
\text {-open ended question on what would motivate you to continue } \\
\text { precepting modified to include 'or incentivize' and to include } \\
\text { precept more often (and to change your mind removed) and to } \\
\text { include in ( )s at end of Q '(include if there is anything } \\
\text { internship directors, students, etc. could do). }\end{array}$ & $\begin{array}{l}\text {-expert opinion, not needed to } \\
\text { answer updated RQs and } \\
\text { asking reasons precept } \\
\text {-expert opinion, so better able } \\
\text { to analyze the data } \\
\text {-modifications based on pilot } \\
\text { responses and expert opinion } \\
\text { during review of pilot survey } \\
\text { and data } \\
\text {-to help obtain more } \\
\text { responses/feedback, optimize } \\
\text { responses } \\
\text {-incentives question to be } \\
\text { 3-point Likert scale per review } \\
\text { and expert opinion }\end{array}$ \\
\hline
\end{tabular}


Table 3.1 (continued)

\begin{tabular}{|c|c|c|c|}
\hline Constructs & Initial Survey & Final Survey & Comments \\
\hline Barriers & $\begin{array}{l}\text { Personal preference for } \\
\text { working with certain DI } \\
\text { programs, if solely their } \\
\text { decision to precept if would } \\
\text { continue to take interns, } \\
\text { barriers to precepting, }\end{array}$ & $\begin{array}{l}\text { No questions added or removed. } \\
\text { Question modifications: } \\
\text {-barriers question reworded, option for not applicable } \\
\text { if there are no barriers, removed, now asking } \\
\text { participant to indicate if they agree or disagree any of } \\
\text { the following are barriers to precepting using 4-point } \\
\text { Likert scale. Removed: computer or technology } \\
\text { related issues because have other similar, my lack of } \\
\text { knowledge/skills or experience (covered in other or } \\
\text { other question), obtaining internship contract } \\
\text { agreement (cover in other response). Added: state } \\
\text { licensure/certification regulations. Modified: lack of } \\
\text { compensation changed to lack of incentives (i.e. } \\
\text { financial compensation), lack interest in precepting } \\
\text { removed and lack of motivation added, regulatory } \\
\text { added to legal issues, quality of intern(s) and } \\
\text { internship program separated as own options...refer } \\
\text { to full final question details in main survey. } \\
\text {-personal preference for working with certain DI } \\
\text { programs responses updated: federal or state agency } \\
\text { added, health care facility, business or corporation } \\
\text { terminology added. Removed last response option } \\
\text { for additional comments. } \\
\text {-if solely their decision to precept if would continue } \\
\text { to take interns' response option of Maybe removed } \\
\text { and responses Yes and No remained, No response } \\
\text { included space for reason, this was also now added } \\
\text { to yes. }\end{array}$ & $\begin{array}{l}\text {-expert opinion and review to change } \\
\text { to a 6-point Likert scale to improve } \\
\text { data for analysis } \\
\text {-terminology changes made per } 2017 \\
\text { ACEND guidelines terminology } \\
\text {-additional comments option was just } \\
\text { for pilot } \\
\text {-expert opinion }\end{array}$ \\
\hline
\end{tabular}


Table 3.1 (continued)

\begin{tabular}{|c|c|c|c|}
\hline Constructs & Initial Survey & Final Survey & Comments \\
\hline Support & $\begin{array}{l}\text { Whether felt supported by } \\
\text { DI programs }\end{array}$ & $\begin{array}{l}\text { Questions removed: } \\
\text {-related to whether feel supported by DI program } \\
\text { and had list and used Likert scale } \\
\text { Questions added: } \\
\text {-9-item support scale added, 6-point Likert scale }\end{array}$ & $\begin{array}{l}\text {-removed since not needed since support } \\
\text { will be covered elsewhere: in support } \\
\text { scale added and in barrier option } \\
\text {-added per literature review, 6-point } \\
\text { scale per review and expert opinion }\end{array}$ \\
\hline Satisfaction & $\begin{array}{l}\text { Satisfaction with their own } \\
\text { internship preceptor } \\
\text { experiences }\end{array}$ & $\begin{array}{l}\text { No questions removed. } \\
\text { Questions added: } \\
\text {-6 statement 6-point Likert scale on satisfaction } \\
\text { with precepting } \\
\text { Question modifications: } \\
\text {-For satisfaction with their own preceptors Likert } \\
\text { scale changed from 5- to 4-point scale }\end{array}$ & $\begin{array}{l}\text {-added based on literature review on } \\
\text { satisfaction (Latessa, community } \\
\text { preceptors) } \\
\text {-expert opinion }\end{array}$ \\
\hline Commitment & Commitment scale & $\begin{array}{l}\text { Question removed: } \\
\text {-statement in scale: "it would take very little } \\
\text { change in my present circumstances to cause me to } \\
\text { stop being a preceptor" removed from } \\
\text { commitment scale } \\
\text { No questions added. } \\
\text { Question modifications: } \\
\text {-final included } 9 \text { statements in scale, statements } \\
\text { updated, 6-point Likert scale }\end{array}$ & $\begin{array}{l}\text { Note: 4-point Likert scale used in pilot } \\
\text { and 6-point in main }\end{array}$ \\
\hline Final general question(s) & $\begin{array}{l}\text { If have additional } \\
\text { comments }\end{array}$ & $\begin{array}{l}\text { Question removed: } \\
\text {-if additional comments wish to discuss had place } \\
\text { to leave contact information } \\
\text { Question added: } \\
\text {-to ask if they would be willing to be re-contacted } \\
\text { within } 1 \text { to } 3 \text { weeks to complete the survey so that } \\
\text { we can further test the reliability of our instrument }\end{array}$ & $\begin{array}{l}\text {-question was only included for purpose } \\
\text { of the pilot (last Q of final survey is } \\
\text { open ended for additional comments) } \\
\text {-expert opinion, if respond yes more } \\
\text { likely to respond vs. sending to the } \\
\text { larger group of respondents }\end{array}$ \\
\hline
\end{tabular}


Table 3.2

Changes in Survey From Pilot to Main Study for Former Preceptors

\begin{tabular}{|c|c|c|c|}
\hline Constructs & Initial Survey & Final Survey & Comments \\
\hline $\begin{array}{l}\text { Demographics } \\
\text { Same as current refer to Table } 3.1\end{array}$ & & & \\
\hline $\begin{array}{l}\text { Dietetics/job-related } \\
\text { In final all Qs same except primary } \\
\text { practice Q not in current preceptor Qs } \\
\text { Refer here and to Table } 3.1\end{array}$ & & $\begin{array}{l}\text { No questions removed. } \\
\text { Question modifications: } \\
\text { - for primary practice area, clinical provided as } \\
\text { example with Health Care response option }\end{array}$ & -added to clarify \\
\hline Preceptor-related & $\begin{array}{l}\text { Preceptor status (current, } \\
\text { former, never), years as a } \\
\text { DI preceptor, when last } \\
\text { precepted, total number of } \\
\text { DIs precepted over career, } \\
\text { how strongly agree or } \\
\text { disagree related to: being } \\
\text { an effective preceptor, } \\
\text { needing training, having } \\
\text { the knowledge/skills to } \\
\text { precept, having access to } \\
\text { an on-call specialist }\end{array}$ & $\begin{array}{l}\text { Questions removed: } \\
\text {-when last precepted } \\
\text {-total number of dietetic interns precepted over } \\
\text { career } \\
\text { Questions added: } \\
\text {-if currently eligible to precept } \\
\text {-have you completed preceptor training } \\
\text {-if able and willing to precept if know how to } \\
\text { sign up } \\
\text {-typical number of interns precepted in } 1 \text { year } \\
\text { Question modifications: } \\
\text { - preceptor status question: 'or' removed from } \\
\text { current preceptor line to clarify meaning } \\
\text { interpreted same, minor modification to order of } \\
\text { former preceptor response (same words) } \\
\text {-how strongly agree or disagree related to being } \\
\text { an effective preceptor, needing training, having } \\
\text { the knowledge/skills, having access to on-call } \\
\text { specialist changed from 5-point Likert scale to } \\
\text { 4-point Likert scale }\end{array}$ & $\begin{array}{l}\text {-expert opinion, do not need to } \\
\text { answer RQs, needed to decrease } \\
\text { length of survey } \\
\text {-also ask similar Qs: years served as } \\
\text { preceptor and number of interns } \\
\text { precept per year } \\
\text {-to make similar to never Qs for } \\
\text { comparison } \\
\text {-to make similar to current and never } \\
\text { Qs for comparison } \\
\text {-to make similar to never Qs for } \\
\text { comparison } \\
\text {-to make similar to current Qs for } \\
\text { comparison } \\
\text {-to clarify } \\
\text {-so response options read in similar } \\
\text { way (Randi) } \\
\text {-Likert scale changed to 4-point } \\
\text { scale, expert opinion (Randi) }\end{array}$ \\
\hline
\end{tabular}


Table 3.2 (continued)

\begin{tabular}{|c|c|c|c|}
\hline Constructs & Initial Survey & Final Survey & Comments \\
\hline Rotation related & $\begin{array}{l}\text { If precepting required and/or } \\
\text { allowed, who makes the final } \\
\text { decision to precept, } \\
\text { involvement in making final } \\
\text { decision, if were primary } \\
\text { preceptor, during which rotation } \\
\text { primarily precept, hours/week } \\
\text { intern under your supervision }\end{array}$ & $\begin{array}{l}\text { Questions removed: } \\
\text {-who makes final decision to precept } \\
\text { Questions added: } \\
\text {-typical number of weeks one intern rotated } \\
\text { (or was assigned to) you during rotation } \\
\text {-are there other RDNs or RDs scheduled to } \\
\text { precept DIs at your current place of } \\
\text { work/employment } \\
\text { Question modifications: } \\
\text {-hours per week intern under your } \\
\text { supervision changed to hours/week on a } \\
\text { typical week intern was assigned to you } \\
\text {-question on during which rotation } \\
\text { primarily precepted instructions reworded } \\
\text { and in response options order of medical } \\
\text { nutrition therapy outpatient changed to } \\
\text { outpatient-medical nutrition therapy and } \\
\text { order of medical nutrition therapy inpatient } \\
\text { also changed to inpatient-medical } \\
\text { nutrition therapy and examples added to } \\
\text { clarify (i.e., hospital, long-term care, rehab) } \\
\text { and order of. Also combined outpatient and } \\
\text { community responses and removed } \\
\text { specialty option }\end{array}$ & $\begin{array}{l}\text {-not needed, kept Q on participant's } \\
\text { involvement in final decision to } \\
\text { precept or not } \\
\text {-to match current Qs for comparison } \\
\text {-to match current Qs for comparison } \\
\text {-to clarify and no longer need } \\
\text { number for CPE approval (since } \\
\text { approved) } \\
\text {-to clarify per pilot responses and } \\
\text { expert opinion } \\
\text { - since informed from TC DI } \\
\text { Director, in TC program almost all } \\
\text { outpatient falls under community, } \\
\text { and specialty options could also fall } \\
\text { under community }\end{array}$ \\
\hline $\begin{array}{l}\text { Time conducting activities - } \\
\text { precepting }\end{array}$ & N/A & & \\
\hline Benefits & N/A & $\begin{array}{l}\text { Questions added: } \\
\text {-Perceived Benefits Scale }\end{array}$ & $\begin{array}{l}\text {-to match current Qs for comparison } \\
\text { (and similar to never Qs) }\end{array}$ \\
\hline
\end{tabular}


Table 3.2 (continued)

\begin{tabular}{|c|c|c|c|}
\hline Constructs & Initial Survey & Final Survey & Comments \\
\hline $\begin{array}{l}\text { Motivators/incentives, } \\
\text { Reason(s) precept }\end{array}$ & $\begin{array}{l}\text { Motivators or incentives would } \\
\text { make more likely to precept }\end{array}$ & $\begin{array}{l}\text { Questions removed: } \\
\text {-Open ended regarding if any issues with or } \\
\text { comments on question asking to rank top } 5 \\
\text { incentives } \\
\text {-which benefits would motivate to precept } \\
\text { Questions added: } \\
\text {-reasons I precepted, } 11 \text { statements and } \\
1 \text { other statement on 4-point Likert scale } \\
\text { Question modifications: } \\
\text {-ranking question on incentives that would } \\
\text { make more likely to precept added (or } \\
\text { precept more often), wording changed to } \\
\text { choose and rank up to } 5 \text { (instead of 5), DPG } \\
\text { abbreviation added, response option for } \\
\text { official designation/title for being a } \\
\text { preceptor added, example of what access to } \\
\text { library resources means added, CPEU } \\
\text { option opportunities changed to offerings } \\
\text { and specified (not including for precepting } \\
\text { itself), expenses paid changed to expenses } \\
\text { paid/reduced cost to attend a national } \\
\text { conference, peer added to public } \\
\text { recognition response and gift card included } \\
\text { with pay/compensation response, CDR } \\
\text { membership changed to fee paid } \\
\text {-open ended question on what would } \\
\text { motivate you to precept modified to include } \\
\text { 'or incentivize' }\end{array}$ & $\begin{array}{l}\text {-only included for pilot to receive } \\
\text { feedback on ranking question } \\
\text {-not needed, asking in modified } \\
\text { ranking question } \\
\text {-expert opinion, to match current } \\
\text { preceptor Qs and improve data } \\
\text { analysis } \\
\text {-modifications based on pilot } \\
\text { responses and expert opinion during } \\
\text { review of pilot survey and data } \\
\text { Likert scale per review and expert } \\
\text { opinion } \\
\text {-incentives question to be } 3 \text {-point } \\
\text { responses/feedback }\end{array}$ \\
\hline
\end{tabular}


Table 3.2 (continued)

\begin{tabular}{|c|c|c|c|}
\hline Constructs & Initial Survey & Final Survey & Comments \\
\hline Barriers & $\begin{array}{l}\text { Personal preference for working } \\
\text { with certain DI programs, if } \\
\text { solely their decision to precept } \\
\text { if would continue to take } \\
\text { interns, barriers to precepting, } \\
\text { reasons I stopped taking interns }\end{array}$ & $\begin{array}{l}\text { Questions removed: } \\
\text { - reasons I stopped taking interns } \\
\text { Questions added: } \\
\text { - personal preference for working with } \\
\text { certain DI programs } \\
\\
\text { Question modifications: } \\
\text {-Barriers question reworded and now asking } \\
\text { participant to indicate if they agree or } \\
\text { disagree any of the following are barriers to } \\
\text { precepting using 4-point Likert scale. Also } \\
\text { see Table } 1 \text { for further details of } \\
\text { modifications made to this Q. } \\
\text {-if solely their decision to precept if would } \\
\text { continue to take interns response options of } \\
\text { Maybe removed and responses Yes and No } \\
\text { remained, No included to include reason } \\
\text { and also added to yes }\end{array}$ & $\begin{array}{l}\text {-not needed to answer RQ and asking } \\
\text { barriers and reasons why precepted } \\
\text {-to match current preceptor Qs for } \\
\text { comparison } \\
\text {-expert opinion to change to Likert } \\
\text { scale, 6-point scale, to improve data } \\
\text { for analysis } \\
\text {-same change made in all three sets } \\
\text { of Qs, expert opinion }\end{array}$ \\
\hline Support & $\begin{array}{l}\text { Whether felt supported by DI } \\
\text { programs }\end{array}$ & $\begin{array}{l}\text { Questions removed: } \\
\text {-related to whether feel supported by DI } \\
\text { program and had list and used Likert scale } \\
\text { Questions added: } \\
\text {-9-item support scale added, 6-point Likert } \\
\text { scale }\end{array}$ & $\begin{array}{l}\text {-removed since not needed, support } \\
\text { will be covered in support scale } \\
\text { added and in barrier option } \\
\text {-added per literature review, using } \\
\text { 4-point Likert scale per expert } \\
\text { opinion }\end{array}$ \\
\hline
\end{tabular}


Table 3.2 (continued)

\begin{tabular}{|c|c|c|c|}
\hline Constructs & Initial Survey & Final Survey & Comments \\
\hline Satisfaction & $\begin{array}{l}\text { Satisfaction with their own } \\
\text { internship preceptor } \\
\text { experiences }\end{array}$ & $\begin{array}{l}\text { No questions removed. } \\
\text { Questions added: } \\
\text {-6-statement 6-point Likert scale on } \\
\text { satisfaction with precepting } \\
\text { Question modifications: } \\
\text {-For satisfaction with your preceptors Likert } \\
\text { scale changed from 5-point to 4-point }\end{array}$ & $\begin{array}{l}\text {-added based on literature review on } \\
\text { satisfaction (Latessa, community } \\
\text { preceptors), 6-point scale per review } \\
\text { and expert opinion }\end{array}$ \\
\hline Commitment & Not included & $\begin{array}{l}\text { Questions added: } \\
\text {-9-item 4-point Likert commitment scale }\end{array}$ & $\begin{array}{l}\text {-addition of scale in this format } \\
\text { added based on expert opinion after } \\
\text { pilot review and so can compare } \\
\text { responses between groups, similar to } \\
\text { final in current and never Qs }\end{array}$ \\
\hline Final general questions & If have additional comments & $\begin{array}{l}\text { Question removed: } \\
\text {-if additional comments wish to discuss had } \\
\text { place to leave contact information } \\
\text { Question added: } \\
\text {-to ask if would be willing to be recontacted } \\
\text { within } 1 \text { to } 3 \text { weeks to complete the survey } \\
\text { so that we can further test the reliability of } \\
\text { our instrument }\end{array}$ & $\begin{array}{l}\text {-question was only included for } \\
\text { purpose of the pilot (last Q of final } \\
\text { survey is open ended for additional } \\
\text { comments) } \\
\text {-expert opinion, if respond yes more } \\
\text { likely to respond vs sending to larger } \\
\text { group }\end{array}$ \\
\hline
\end{tabular}


Table 3.3

Changes in Survey From Pilot to Main Study for Never Preceptors

\begin{tabular}{|c|c|c|c|}
\hline Constructs & Initial Survey & Final Survey & Comments \\
\hline $\begin{array}{l}\text { Demographics } \\
\text { Same as current refer to Table } 3.1\end{array}$ & & & \\
\hline $\begin{array}{l}\text { Dietetics/job-related } \\
\text { In final all Qs same except primary } \\
\text { practice Q not in current preceptor } \\
\text { Qs } \\
\text { Refer here and to Table } 3.1\end{array}$ & & $\begin{array}{l}\text { No Questions removed. } \\
\text { Question modifications: } \\
\text { - for primary practice area, clinical } \\
\text { provided as example with Health } \\
\text { Care response option }\end{array}$ & -added to clarify \\
\hline Preceptor-related & $\begin{array}{l}\text { Preceptor status (current, former, } \\
\text { never), if ever asked to precept, } \\
\text { eligibility to precept, if able and } \\
\text { willing to precept if know how to } \\
\text { sign up, how strongly agree or } \\
\text { disagree related to: being an } \\
\text { effective preceptor, needing training, } \\
\text { having the knowledge/skills to } \\
\text { precept, having access to an on-call } \\
\text { specialist }\end{array}$ & $\begin{array}{l}\text { Questions removed: } \\
\text {-if in agreement if would be allowed } \\
\text { to precept more than } 1 \text { intern } \\
\text { Questions added: } \\
\text {-if completed preceptor training } \\
\text { Question modifications: } \\
\text { - preceptor status question: 'or' } \\
\text { removed from current preceptor line } \\
\text { to clarify meaning interpreted same, } \\
\text { minor modification to order of } \\
\text { former preceptor response (same } \\
\text { words) } \\
\text {-how strongly agree or disagree } \\
\text { related to being an effective } \\
\text { preceptor, needing training, having } \\
\text { the knowledge/skills, having access } \\
\text { to on-call specialist changed from } \\
\text { 5-point Likert scale to 6-point Likert } \\
\text { scale }\end{array}$ & $\begin{array}{l}\text {-expert opinion, do not need to } \\
\text { answer RQs, needed to decrease } \\
\text { length of survey } \\
\text {-addition based on expert opinion of } \\
\text { matching questions throughout } 3 \\
\text { participant groups wherever possible } \\
\text { to improve collection and analysis of } \\
\text { data } \\
\text {-to clarify } \\
\text {-so response options read in similar } \\
\text { way } \\
\text {-Likert scale changed to 6-point } \\
\text { scale, expert opinion }\end{array}$ \\
\hline
\end{tabular}


Table 3.3 (continued)

\begin{tabular}{|c|c|c|c|}
\hline Constructs & Initial Survey & Final Survey & Comments \\
\hline Rotation-related & $\begin{array}{l}\text { If precepting required and/or } \\
\text { allowed, in current position who } \\
\text { makes the final decision to precept, } \\
\text { involvement in making final decision } \\
\text { to precept }\end{array}$ & $\begin{array}{l}\text { Questions removed: } \\
\text {-who makes final decision to precept } \\
\text { Questions added: } \\
\text { - in your practice area typical } \\
\text { number of weeks one intern rotates } \\
\text { with (or is assigned to) preceptor } \\
\text { - in your practice area hours per } \\
\text { week on typical week each intern } \\
\text { assigned to preceptor } \\
\text {-are other RDs scheduled to precept } \\
\text { interns at your current place of } \\
\text { work/employment } \\
\text { Question modifications: }\end{array}$ & $\begin{array}{l}\text {-not needed, kept Q on participant's } \\
\text { involvement in final decision to } \\
\text { precept or not } \\
\text {-additions based on expert opinion of } \\
\text { matching questions as close as } \\
\text { possible throughout three participant } \\
\text { groups wherever can to improve } \\
\text { collection and analysis of data }\end{array}$ \\
\hline $\begin{array}{l}\text { Time conducting activities- } \\
\text { precepting }\end{array}$ & N/A & & \\
\hline Benefits & Not included & $\begin{array}{l}\text { Questions added: } \\
\text {-6-item Perceived Benefits Scale on } \\
\text { 6-point Likert scale, asked how } \\
\text { strongly agree or disagree each of the } \\
\text { following would be true if you } \\
\text { precepted } \\
\text {-perception of how RDs would } \\
\text { respond to reasons why they precept, } \\
11 \text { statements and } 1 \text { other item, on } \\
\text { 6-point Likert scale }\end{array}$ & $\begin{array}{l}\text {-additions based on expert opinion } \\
\text { after reviewing pilot, to be similar to } \\
\text { current and former Qs for } \\
\text { comparison }\end{array}$ \\
\hline
\end{tabular}


Table 3.3 (continued)

\begin{tabular}{|c|c|c|c|}
\hline Constructs & Initial Survey & Final Survey & Comments \\
\hline $\begin{array}{l}\text { Motivators/incentives, } \\
\text { Reason(s) RDs precept }\end{array}$ & $\begin{array}{l}\text { Motivators or incentives would } \\
\text { make more likely to precept or } \\
\text { precept more often }\end{array}$ & $\begin{array}{l}\text { Questions removed: } \\
\text {-ranking incentives question removed } \\
\text {-Open ended regarding if any issues with } \\
\text { or comments on question asking to rank } \\
\text { top } 5 \text { incentives } \\
\text { No questions added. } \\
\text { Question modifications: } \\
\text {-question on incentives that would make } \\
\text { more likely to precept, wording changed to } \\
\text { include DPG abbreviation added, response } \\
\text { option for official designation/title for } \\
\text { being a preceptor added, example of what } \\
\text { access to library resources means added, } \\
\text { CPEU option opportunities changed to } \\
\text { offerings and specified (not including for } \\
\text { precepting itself), expenses paid changed } \\
\text { to expenses paid/reduced cost to attend a } \\
\text { national conference, peer added to public } \\
\text { recognition response and gift card included } \\
\text { with pay/compensation response, CDR } \\
\text { membership changed to fee paid } \\
\text {-open-ended question on what would } \\
\text { motivate you to start precepting modified } \\
\text { to include 'or incentivize' }\end{array}$ & $\begin{array}{l}\text {-modifications based on pilot } \\
\text { responses and expert opinion during } \\
\text { review of pilot survey and data }\end{array}$ \\
\hline
\end{tabular}


Table 3.3 (continued)

\begin{tabular}{|c|c|c|c|}
\hline Constructs & Initial Survey & Final Survey & Comments \\
\hline Barriers & $\begin{array}{l}\text { If solely their decision to precept if } \\
\text { would continue to take interns, } \\
\text { barriers to precepting, reasons do not } \\
\text { precept }\end{array}$ & $\begin{array}{l}\text { Questions removed: } \\
\text { Questions added: } \\
\text { Question modifications: } \\
\text {-barriers question reworded and now } \\
\text { asking participant to indicate if they } \\
\text { agree or disagree any of the following } \\
\text { are barriers to them precepting using 6- } \\
\text { point Likert scale. Also see Table } 1 \text { for } \\
\text { further details of modifications made } \\
\text { to this Q. } \\
\text {-if solely their decision to precept if } \\
\text { would continue to take interns } \\
\text { response option of Maybe removed } \\
\text { and responses Yes and No remained, } \\
\text { No response included space for reason, } \\
\text { now also added to Yes response }\end{array}$ & $\begin{array}{l}\text {-expert opinion to change to Likert } \\
\text { scale, 6-point scale, to improve data } \\
\text { for analysis } \\
\text {-same change made in all } 3 \text { sets of } \\
\text { Qs, expert opinion }\end{array}$ \\
\hline Support & N/A & 9-item support scale, 6-point Likert & \\
\hline Satisfaction & $\begin{array}{l}\text { Satisfaction with their own } \\
\text { internship preceptor experiences }\end{array}$ & $\begin{array}{l}\text { No questions removed. } \\
\text { Questions added: } \\
\text {-6-statement 6-point Likert scale on } \\
\text { statements related to satisfaction with } \\
\text { precepting, based on how feel would } \\
\text { be true for you if precepted } \\
\text { Question modifications: } \\
\text {-for satisfaction with your preceptors } \\
\text { Likert scale changed from 5-point to } \\
\text { 4-point scale }\end{array}$ & $\begin{array}{l}\text {-addition of scale based on literature } \\
\text { review on satisfaction (Latessa, } \\
\text { community preceptors) and so } \\
\text { similar to current and former Qs for } \\
\text { comparison } \\
\text {-expert opinion }\end{array}$ \\
\hline
\end{tabular}


Table 3.3 (continued)

\begin{tabular}{|c|c|c|c|}
\hline Constructs & Initial Survey & Final Survey & Comments \\
\hline Commitment & Not included & $\begin{array}{l}\text { Questions added: } \\
\text {-9-item 6-point Likert commitment } \\
\text { scale added, asked how think } \\
\text { preceptors would respond } \\
\text { Question modifications: } \\
\text {-statements updated }\end{array}$ & $\begin{array}{l}\text {-addition of scale in this format } \\
\text { added based on expert opinion after } \\
\text { pilot review, scale used in current } \\
\text { and added to former preceptor Qs, so } \\
\text { benefit if similar so can compare } \\
\text { commitment between groups }\end{array}$ \\
\hline Final general questions & If have additional comments & $\begin{array}{l}\text { Question removed: } \\
\text {-if additional comments wish to } \\
\text { discuss had place to leave contact } \\
\text { information } \\
\text { Question added: } \\
\text {-to ask if would be willing to be } \\
\text { recontacted within } 1 \text { to } 3 \text { weeks to } \\
\text { complete the survey so that we can } \\
\text { further test the reliability of our } \\
\text { instrument }\end{array}$ & $\begin{array}{l}\text {-question was only included for } \\
\text { purpose of the pilot (last Q of final } \\
\text { survey is open ended for additional } \\
\text { comments) } \\
\text {-expert opinion, if respond yes more } \\
\text { likely to respond vs. sending to } \\
\text { larger group }\end{array}$ \\
\hline
\end{tabular}




\section{Main Study Measures}

Quantitative data, and to a lesser extent qualitative data, were collected on the demographics, dietetics/job-related, preceptor-related, rotation-related, benefits, motivators/incentives, barriers, support for the preceptor role, satisfaction, and commitment to the preceptor role.

\section{Required Questions}

After the first question required for consent was complete, two more required questions followed. Participants were asked if they were an RD or an RDN; if yes, the survey continued, and if no, the survey ended. Participants who answered yes were then asked their preceptor status (current, within the past year; former, greater than 1 year ago; never precepted); their response directed the questions that followed accordingly.

Demographics. (7 questions for all 3 participant groups - current, former, never) Six items were used to describe the demographics of the sample, including geographic location, asking participants to choose the state they were working in, or if not working, the state they were residing in (drop down of states, includes "I do not reside in the US"); description of area where working or reside (urban, suburban, rural, other); highest level of education completed in nutrition/dietetics-related field (bachelor's, master's, doctorate); age (continuous); gender (female, male, transgender, other); race (American Indian or Alaskan Native, Asian or Pacific Islander, Black, White, Mixed, Other [specify]); and ethnicity (Hispanic, Non-Hispanic)—responses for ethnicity/race originated from page related to IRB training. Demographic questions were also similar to Catherine Arnold et al. (2016) and Winham et al. (2014). 
Dietetics/job-related information. (12 questions, current; 13 questions, former and never, plus two additional questions for all depending on responses to leadership and specialization credential questions); 12 to 13 items, plus two additional items if certain responses were indicated were asked of participants related to dietetics/job-related information. Of these questions, two questions were related to registration/credentials (plus an additional one depending on response to credential question), four were workrelated, two were professional membership group questions, and two were leadership/ teaching questions (plus an additional related question depending on response to leadership questions).

After the participant agreed to give consent, the first required question asked if the participant was a Registered Dietitian/Registered Dietitian Nutritionist (yes, no-if chosen skips to end survey); if they held any additional specialization credentials (yes, no), then specify if yes (Advanced Practice Certification in Clinical Nutrition, Board Certified Specialist options, CDE, CNSC, etc., other, N/A). The four work-related questions included if currently working in the field of nutrition/dietetics (yes, full-time; yes, parttime; yes, per diem or other; no, out of field 1 year or less, out of field for more than 1 year); former and never participants were asked their primary practice area (i.e., academia, business, and industry/corporate, communication/publication); years working in field of nutrition/dietetics (continuous); and years working in current/most recent position (continuous).

Participants were asked if they were AND members (yes, former member, never) and if they were members of the Nutrition and Dietetics Educators and Preceptors (NDEP) Dietetic Practice Group (DPG) of AND (yes, former member, never). Per a 
suggestion by Catherine Arnold et al. (2016), two items were added to this area-one related to teaching outside of the preceptor role (yes, no) and one related to holding of a professional leadership position in the field of nutrition/dietetics (yes, no). If yes was answered to currently or previously holding a leadership position, then they were asked to choose all that applied in specifying the setting(s) (i.e., academia, health care). All participants were asked if any of the following applied: dietetic internship (DI) director or coordinator, work for a DI program, work for ACEND, on a DI advisory committee, on a DI admissions committee, N/A.

All participants were also asked when they were a DI, if they were in a distance learning internship program (yes, no, N/A), and what type of internship program they were in (college/university, company-based, e.g., business: Sodexo, Aramark, etc., federal or state agency, hospital/health care facility-based, other: , N/A).

Preceptor-related questions. (4-5 Qs current, 11-12 Qs former, 9-10 Qs never). The first question asked during the survey of all participants related to this area was the participants' preceptor status (current, within past year, former, greater than 1 year, never); based on this response, the online survey was programmed with a skip pattern to bring the participant to the appropriate questions. There were three general sets of questions: current preceptors, former preceptors, never precepted. Questions for current and former preceptors included number of years served as a Dietetic Internship (DI) preceptor in the United States (continuous, rounded to nearest year), and the typical number of interns precept(ed) in 1 year (continuous). Former preceptors were asked when they last precepted (continuous, year). 
All participants were asked if they had completed preceptor training (yes, no) and, if yes, if received formal training-i.e., structured, class, online course (yes, no), and/or informal training-i.e., unstructured, written resources (yes, no).

Former and never participants were asked if they were eligible to precept for a U.S.-accredited Dietetic Internship program (yes, eligible to precept; do not know if eligible to precept, explain; no, not eligible to precept, explain) (same/similar Catherine Arnold et al., 2016), and if they were able and willing to precept if they knew how to sign up to precept (yes, no). Using a 6-point Likert scale, former and never participants were also asked to indicate how strongly they agreed or disagreed with the following statements related to precepting a dietetic intern: "I would be an effective preceptor" (this statement was similar in Winham et al.'s [2014] Arizona dietetics), “I would need training before precepting a dietetic intern," "I am confident I have the knowledge and skills to precept," "I would be more likely to precept if I had access to an on-call specialist - i.e., to answer questions related to my area of practice while precepting." No versions of this question were asked of current preceptors secondary to time restraints of the survey.

Those who never precepted were asked if they had ever been asked to serve as a preceptor for a U.S.-accredited (i.e., accredited by CADE/ACEND) Dietetic Internship program (yes, not sure, no) (similar to Catherine Arnold et al., survey 2013; abstract 2016).

Rotation-related questions. (6-7 Qs current, 7-8 Qs former, 3 Qs never). There were 7-8 rotation-related questions. Although most of the questions (6-7) pertained more 
to current and former preceptors, applicable questions were slightly modified accordingly based on preceptor status.

All participants were asked, if in your most recent position, is/was being a preceptor required, not required but allowed ("but allowed" not in current response options), not allowed or against policy (not in current)," or they could choose N/A if not currently working or not sure. All participants were also asked if "in your current position or most recent position, were you involved in the final decision to precept, or not to precept?" (yes, no, N/A).

Current and former preceptors were asked if they were the primary preceptor for the dietetic intern's rotation-i.e., signing off on evaluations, hours, and so on that were returned to the internship program (yes, always; yes, sometimes; no; I am not sure), and during which rotation they typically precepted (inpatient clinical/MNT-i.e., hospital/ long-term care/rehab, outpatient MNT/community nutrition-i.e., food banks/community centers/WIC, food service management, research, other). Participants were instructed to choose the one rotation they primarily precepted and to answer the rest of the questions in the survey based on their experience precepting during this rotation. Those who responded that they primarily precepted during the intern's Clinical/Medical Nutrition Therapy (inpatient) rotation were asked to specify where they primarily precepted-i.e., hospital (acute care), nursing home (long-term care) or transitional care, rehabilitation, other.

Current and former participants were asked to indicate while precepting what was the typical number of weeks one intern rotated with them during their rotation (continuous, max 2 digits), similar to Winham et al.'s (2014) Arizona dietetics. 
Participants were also asked to include the typical number of hours per week that each intern was assigned to them (continuous, max 2).

Former and never participants were asked if in the last 12 months other RDs or RDNs were scheduled to precept dietetic intern(s) at their current place of work/employment? (yes, do not know, no, not applicable).

Benefits. (3 Qs current and former, included a 6-item scale; 2 Qs never, included a 6-item scale). Benefits/gains of being a preceptor were measured using eight items in the survey. Six of the items were included in a perceived benefits scale (knowledge/skills gained). This scale was adapted and modified from the Preceptor's Perceptions of Benefits and Rewards (PPBR) scale, which originated in the nursing literature with Dibert and Goldenberg (1995). Hyrkas and Shoemaker (2007) used a similar 14-item scale (adapted from Dibert \& Goldenberg, 1995) with nursing undergraduates and new hires. The six statements (using a 6-point Likert scale from strongly disagree to strongly agree) out of the 14 chosen to be used in the current survey pertained more to the research questions at hand related to dietetic internship preceptors. Any modifications of the statements used by Hyrkas and Shoemaker are indicated within [brackets]. Participants were asked to indicate how strongly they agreed or not that as a preceptor they had the opportunity to: learn from [dietetic interns], keep current and remain stimulated in their profession, increase their own professional knowledge base, improve their teaching skills, improve their organizational skills, and improve my leadership skills. Also important to note, three of the six statements (keep current and remain stimulated in my profession, increase my own professional knowledge base, improve my teaching skills) were similar to those used in research by Winham et al. (2014), who 
surveyed current and former dietetic preceptors and nonpreceptors in Arizona using a 5-point Likert scale. Never participants were asked if they felt the statements would be true for them if they precepted.

The reliability reported by Dibert and Goldenberg (1995) for the PPBR scale included a Cronbach alpha coefficient of 0.91, and by Hyrkas and Shoemaker (2007) a Cronbach alpha of 0.90 . The pilot data with 39 participants indicated that this benefits scale had high internal reliability (Cronbach alpha, 0.907).

Participants were also asked one question on why they precept or precepted (interns create positive change for the department/organization, it is my professional responsibility, relationship with Dietetic Internship Program/Director, required by workplace, tangible benefits - i.e., tuition credit, continuing education units, monetary compensation, etc., to contribute to the future of the profession, to give back to the program or field, to learn from the intern/keep up-to-date, to network/stay connected, to screen potential employees or job recruit, to teach, mentor, and/or introduce students/interns to the field, other). Participants who never precepted were asked to choose the response which best described if the statement was related to why they would precept dietetic interns. Latessa et al. (2013) conducted research in North Carolina on community preceptors, which did not include dietetics preceptors, and found the perceived importance of reasons to precept students (in 2011) included: giving back to the profession (99.4\%), demonstrating community practice (99\%), intellectual stimulation (98.7\%), enjoyment of teaching (98.5\%), being a role model (97.3\%), keeping their knowledge up-to-date (91\%), renewed importance to work (87.9\%), student 
appreciation of their teaching (84.4\%), student contribution to practice $(72.3 \%)$, and helping recruit for their specialty $(70.8 \%)$.

Current and former participants were asked one question regarding if they received any of the following, from a list of benefits, for precepting (i.e., AND membership fee paid, CPEU offerings for precepting, CPEU offerings—not including the act of precepting itself, pay or monetary compensation/gift card, tuition credit). This question was adapted from a question used by Winham et al.'s (2014) Arizona dietetics, Latessa et al.'s (2013) North Carolina community preceptors (not including dietetics), and feedback from preceptors and Dietetic Internship directors.

Motivators/incentives to precepting. (4 Qs for all). Two items asked were related to motivators/incentives to precepting. All participants were asked to look at a list of potential incentives and indicate whether they would increase the likelihood to act as a preceptor on a 3-point scale of very likely—asked to reserve only for those very important to them, somewhat likely, not very likely (i.e., AND membership fee paid, CPEU for precepting, CPEU offerings — not including for precepting itself, pay or monetary compensation/gift card, tuition credit). They were also asked an open-ended question on "what would motivate or incentivize them to continue to precept or precept more often that we haven't already covered and to include if there is anything internship directors, students, etc. could do.”

Two questions were added after the pilot related to a recent change: "Did you know that as of June 2017, RDNs can receive continuing education credit for precepting?" (yes, no) and "Knowing that you can receive CE credit for precepting, would that make you more likely to precept?" (Not applicable: I would precept with or 
without CE credits; No, no amount of CE credits would make it more likely for me to precept; Maybe, if I could receive more than 3 credits a year; Yes, receiving CE credits somewhat increases my likelihood to precept; Yes, receiving CE credits greatly increases my likelihood to precept). Note that an item covering if the participant was satisfied with the incentives offered/received for precepting was also included in the satisfaction questions; see satisfaction section of main study measures.

Barriers to precepting. (3 Qs current, 4 Qs former, 3 Qs never). Four items were related to the barriers to precepting, including for all participants that if it was solely their decision, would they continue to take interns (yes, include reason; no, include reason). The item asking if they would continue taking interns was modified from an item in a national convenience dietetics survey by Catherine Arnold et al. (2016) and a similar question was also asked by Latessa et al. (2013, North Carolina, community preceptors, not dietetics, if will continue precepting in the next 5 years).

All participants were asked to indicate if they agreed or disagreed on a 6-point Likert scale if any of the following items were barriers to them precepting: lack of appreciation/recognition, lack of incentives (i.e., financial compensation), lack of personal motivation, lack of preceptor support, lack of training, length of rotation, legal issues (i.e., internship contracts or agreements) and/or liability/regulatory concerns, my health and/or family/personal obligations, not enough for interns to do at my workplace, negative experience with internship program/prior intern, quality of the intern(s), quality of the internship program, restricted by facility or management, short staffed or downsizing, state licensure/certification regulations, stress from having interns, technology or electronic medical record issues, time-consuming/increased workload, unable to 
demonstrate added value of having interns, unfamiliar with the internship program, workspace limitations. To obtain more information regarding barriers, participants were next asked an open-ended question: "If there are any other barriers or reasons they do not precept (or do not precept more often) that we haven't already covered?"

Latessa et al. (2013) mentioned how they did not have data to know why the preceptors who discontinued teaching did so, which would support the inclusion of the question for former preceptors on reasons why they stopped taking interns (i.e., changes in management, stress or personal circumstances, workload or short-staffed). Note that questions under preceptor-related questions, depending on responses, could also indicate barriers (i.e., if aware eligible, training, etc.).

Support for the preceptor role. (1 Q, 9-item scale for all). Support for the preceptor role was measured using a modified version of the Preceptor's Perceived Support Scale from the nursing literature by Dibert and Goldenberg (1995) and Hyrkas and Shoemaker (2007). This support scale included nine statements with reference to the participants' experience as a dietetic internship preceptor and asked them to choose, on a 6-point Likert scale from strongly disagree to strongly agree, which best described their response to each of the statements. The full support scale is included in the survey in Appendix L1. A few examples of the statements included are below:

- I feel I have had adequate support from the Dietetic Internship Program(s).

- The goals as a preceptor are clearly defined.

- Support is available to help preceptors develop in their role.

A final statement in the scale on management/administration are supportive of RDs in the preceptor role was added secondary to the nursing literature as well as the 
research on precepting in dietetics by Winham et al. (2014). The support scale instructions for those who never precepted asked them to consider each statement imagining "what support you think there would be for the preceptor role" and "if helpful may also think about preceptors they know or about the support preceptors received during their internship."

The reliability reported by Dibert and Goldenberg (1995) for the Preceptor's Perceptions of Support (PPS) scale included a Cronbach alpha of 0.86, and by Hyrkas and Shoemaker (2007) a Cronbach alpha of 0.75 (0.85 in the pilot). Our pilot data with 39 participants indicated that this support scale had high internal validity (Cronbach alpha $0.912)$.

Satisfaction. (2 Qs for all-1 is 6-item scale). All participants were asked to reflect on when they were dietetic interns, how satisfied were they with their preceptor experiences, on a 4-point Likert scale from very dissatisfied to very satisfied (option also included for not applicable).

Satisfaction was measured using a satisfaction scale (adapted/modified from the satisfaction subscale of the Clinical Preceptor Experience Evaluation Tool (CPEET), (O’Brien et al., 2014; 9-item satisfaction section on 7-point Likert scale), where current and former preceptors were asked to consider each of six statements with reference to their experience as dietetic internship preceptors, and indicate how strongly they agreed or disagreed on a 6-point Likert scale (strongly disagree to strongly agree) with the following statements:

- I am satisfied with the incentives offered/received for precepting (see below, not part of CPEET). 
- Being a preceptor is satisfying.

- The role of preceptor is professionally rewarding.

- I enjoy the intern/preceptor interaction.

- The preceptor role is an incentive to teach.

- It is stimulating to work with enthusiastic interns.

Those who have never precepted were asked how strongly they agreed or disagreed that the statements would be true for them if they precepted and if helpful may also think about preceptors they know or about the support preceptors received during their internship.

The item covering if participants were satisfied with the incentives offered/ received for precepting was added to the 6-point Likert scale statements secondary to a question included by Latessa et al. (2013, North Carolina, community preceptors - not including dietetics) on satisfaction with overall incentives they received to teach.

Latessa et al. (2013, North Carolina, community preceptors—not including dietetics) asked about overall satisfaction with precepting, which showed high, but it was mentioned to be limited around preceptor satisfaction since it lacked more detail about the small group of preceptors who responded negatively.

Commitment to the preceptor role. (1 Q with similar 9-item scale for all). Commitment was measured using a modified version of the Commitment Scale used in the nursing literature by Dibert and Goldenberg (1995) and Hyrkas and Shoemaker (2007). This commitment scale included nine statements and asked the participant to choose, on a 6-point Likert scale from strongly disagree to strongly agree, which best described their feelings about the statement. Wording in one of the nine statements was 
slightly modified to pertain to the former respondents and four of the nine were slightly modified to pertain to the never-precepted respondents. The full commitment scale, including the modifications made for each set of respondents, is included in the survey in Appendix L. A few examples of the statements used are below:

- $\quad$ Being a preceptor inspires me to perform my best.

- $\quad$ Deciding to be a preceptor was a mistake on my part.

- I am proud to tell others that I am a preceptor.

- I am enthusiastic about the preceptor role when I talk to my colleagues.

The reliability reported by Dibert and Goldenberg (1995) for the Commitment to the Preceptor Role (CPR) scale included a Cronbach alpha of 0.87 , and by Hyrkas and Shoemaker (2007) a Cronbach alpha of 0.86. Our pilot data with 39 participants and nine statements indicated that this commitment scale had high internal validity (Cronbach alpha 0.874 , ICC 0.831 [p = 0.001], Pearson correlation $0.804[p=0.0005])$.

Final additional questions. All participants were asked if they had additional comments related to precepting (benefits, support, incentives, motivators, satisfaction, barriers, commitment, etc.) or any of the questions in this survey (open-ended). All participants were asked if they would be willing to be recontacted within 1 to 3 weeks to complete the survey again to allow for further testing of the quality of the instrument (yes, no).

Table 3.4 includes the study timeline and activities conducted. 
Table 3.4

Study Timeline

\begin{tabular}{ll}
\hline \multicolumn{1}{c}{ Time } & \multicolumn{1}{c}{ Study Activity } \\
\hline Spring 2013-Spring 2015 & $\begin{array}{l}\text { Search for a dissertation topic. Literature review and pilot survey } \\
\text { developed. Pilot TC IRB approval received. (Fall 2013 maternity leave) }\end{array}$ \\
\hline Summer/Fall 2015 & $\begin{array}{l}\text { Pilot RDN survey conducted, followed by pilot retest, pilot survey data } \\
\text { analysis and review. }\end{array}$ \\
\hline Spring 2016 & $\begin{array}{l}\text { Appeal to request more than 2500 RDN names from CDR approved, main } \\
\text { national survey TC IRB approval received, CDR approved request for full } \\
\text { national list of RDNs for student research and list of RDNs received- } \\
\text { must send results to CDR once complete }\end{array}$ \\
\hline Spring/Summer/Fall 2016 & Expanding upon and reorganizing Chapters I-III, updating survey. \\
\hline Spring 2017 & $\begin{array}{l}\text { Preparing Chapters I-III for Proposal Hearing. Finalizing main RDN } \\
\text { survey to be distributed after final approval, modifications to IRB for } \\
\text { approval. }\end{array}$ \\
\hline Summer 2017 & $\begin{array}{l}\text { Proposal Hearing July 5, 2017. Made recommended modifications and } \\
\text { updates sent to IRB for approval. Main research advisor changed from } \\
\text { Randi Wolf to Pamela Koch per recommendation. }\end{array}$ \\
\hline Fall 2017 & Medical leave of absence/maternity leave. \\
\hline Spring/Summer 2018 & $\begin{array}{l}\text { Further review and updating of survey and retest to ensure obtaining data } \\
\text { needed for analysis and obtaining it in a way that would best facilitate } \\
\text { analyzing the data accordingly (new advisor Pamela Koch and new } \\
\text { statistical support). }\end{array}$ \\
\hline Fall 2018 & $\begin{array}{l}\text { Survey finalized, IRB approval of modifications obtained. Survey } \\
\text { distributed and data collected for approximate 2-month period (Oct-Dec). }\end{array}$ \\
\hline Winter/Spring 2019 & $\begin{array}{l}\text { Cleaning, coding, and analyzing data. Completion of Chapters IV and V. } \\
\text { Seminar data hearing April 4. Dissertation Oral Defense April 18. }\end{array}$ \\
\hline &
\end{tabular}

Data Analysis Plan

The main study descriptive data were analyzed in TC Qualtrics software and SPSS, and questionnaire and demographic data were exported to SPSS for coding and further analysis. The data from the short-answer text-box options included with questions throughout the survey, e.g., "other," "explain," "include reason," etc. (Qs 7C, 7F, 8C, 8F, 11.6F, 11.6N, 17C, 17F, 19.5F, 27.1, 28N, 28.6F, 28.6N, 34, 41, 46, 47b) were reviewed and coding updated accordingly if applicable for that question. 
Scale scores were created for each of the individual measures in the survey, including potential benefits, support, satisfaction, and commitment, by summing the Likert item scores in each scale and dividing by the total number of questions in each construct (Winham et al., 2014). Scale internal consistency/reliability were assessed using Cronbach's alpha. Table 3.5 shows the research questions, measures (survey questions), and the data analysis plan associated with each.

Table 3.5

Research Questions, Measures, and Data Analysis Plan

\begin{tabular}{|c|c|c|}
\hline Research Question & $\begin{array}{c}\text { Measure } \\
\text { (Survey Question) }\end{array}$ & Analysis \\
\hline \multirow{3}{*}{$\begin{array}{l}\text { 1. What incentivizes or } \\
\text { motivates RDNs } \\
\text { currently in the preceptor } \\
\text { role to precept? What } \\
\text { would motivate more } \\
\text { RDNs to take on the } \\
\text { preceptor role? }\end{array}$} & $16 \mathrm{a}, 18,23$ & $\begin{array}{l}\text { Welch F test to compare three group means, } \\
\text { Games Howell Post Hoc }\end{array}$ \\
\hline & $23.5 \mathrm{FN}$ & $\begin{array}{l}\text { Independent-samples t-test to compare two group } \\
\text { means }\end{array}$ \\
\hline & $26,28,48 \mathrm{a}, 48 \mathrm{~b}$ & $\begin{array}{l}\text { Pearson’s Chi-Square, effect size Cramer’s V } \\
\text { Adjusted Residual Post Hoc }\end{array}$ \\
\hline \multirow{3}{*}{$\begin{array}{l}\text { 2. What are the barriers } \\
\text { to precepting for } \\
\text { RDNs? }\end{array}$} & $19.5 \mathrm{~F}$ & $\begin{array}{l}\text { Descriptive Statistics, including means, standard } \\
\text { deviations, frequencies and proportions }\end{array}$ \\
\hline & 20 & $\begin{array}{l}\text { Totals and means-added new variables } \\
\text { Welch F test to compare three group means, } \\
\text { Games Howell Post Hoc }\end{array}$ \\
\hline & $23.5 \mathrm{FN}$ & Independent-samples t-test \\
\hline \multirow{2}{*}{$\begin{array}{l}\text { 3. What are the RDs } \\
\text { perceived benefits, } \\
\text { support, satisfaction and } \\
\text { commitment to the } \\
\text { preceptor role? }\end{array}$} & $12,13,14,23$ & $\begin{array}{l}\text { Scale totals and means-added new variables } \\
\text { Welch F test to compare three group means, } \\
\text { Games Howell Post Hoc }\end{array}$ \\
\hline & $12,13,14,20,23$ & Pearson Correlation among scales and barriers \\
\hline $\begin{array}{l}\text { 4. What factors are } \\
\text { associated with RDNs } \\
\text { being current preceptors? }\end{array}$ & $\begin{array}{l}13,30,31,35,34 \\
36 a, 39\end{array}$ & $\begin{array}{l}\text { Pearson Correlation among variables in final } \\
\text { regression model } \\
\text { Binary Logistic Regression }\end{array}$ \\
\hline
\end{tabular}

Survey questions were asked of all survey respondents unless indicated differently $(\mathrm{C}=$ current preceptors, $\mathrm{F}=$ former preceptors, $\mathrm{N}=$ never precepted).

Note: Those asked of all participants used the same language when pertained, question stems/item wording were slightly modified according to preceptor status (survey questions for all respondents are in the Main Survey, please refer to Appendix L). 
Descriptive statistics (means, SDs, frequencies, percentages) were calculated for demographic variables, including age, gender, ethnicity, race, geographic location, and highest level of education completed in related field, and examined for the sample as a whole and by preceptor status: current, former, never.

To compare group means across the three preceptor statuses for the variables related to potential incentives, satisfaction with precepting, barriers, and survey scale scores, Welch's ANOVA test was conducted since the data violated the assumption of homogeneity. When significant differences were found between the groups, a post-hoc analysis using Games Howell was conducted to identify where the significant differences were between the groups.

T-tests were calculated to compare mean scores for questions that only compared responses between the never precepted and former preceptor groups, such as regarding if they would be more likely to precept if they had access to an On-Call Specialist, if they felt they would be an effective preceptor, if they felt confident in their knowledge and skills to precept, if they would need more training before precepting, etc., which were only asked of former and never preceptors.

To assess the association between categorical variables, a chi-square test for independence was calculated to understand whether receipt of continuing education credit for precepting would make the RDNs more likely to precept. A chi-square analysis was also used for the question that asked RDNs would they precept if it was solely their decision and for the question that asked the RDNs if they were involved in the final decision to precept. Adjusted residuals were used for post-hoc analysis. 
Pearson correlation coefficients were calculated to quantify the strength and direction of the association among the benefits, commitment, satisfaction, support, and barrier scales scores.

Finally, a binary logistic regression was performed to evaluate the probability of choosing to be a preceptor, given an RDN's responses to questions about demographics, preferences regarding incentives, perceptions regarding barriers, and so on.

Table 3.6 shows the rationale for factors included in the final regression model. 
Table 3.6

Rationale for Factors Included in Regression Model

\begin{tabular}{|c|c|c|}
\hline Factors & $\begin{array}{l}\text { Measure } \\
\text { (Survey } \\
\text { Question) }\end{array}$ & Rationale \\
\hline Year RDN & 31 & $\begin{array}{l}\text { RDNs with more experience may have had more } \\
\text { time to make connections in the field with internship } \\
\text { programs. } \\
\text { RDNs with fewer years of experience may feel more } \\
\text { comfortable or confident precepting since they may } \\
\text { be more familiar with current programs, recently } \\
\text { being an intern. }\end{array}$ \\
\hline Highest Degree & 35 & $\begin{array}{l}\text { RDNs with a higher degree may be more involved } \\
\text { in educating others in the field. }\end{array}$ \\
\hline Specialization Credential & $36 \mathrm{a}$ & $\begin{array}{l}\text { RDNs who hold a specialization credential may feel } \\
\text { more confident in their area of expertise and } \\
\text { therefore be more likely to precept. }\end{array}$ \\
\hline Work Status & 30 & $\begin{array}{l}\text { RDNs who work full-time may have more hours } \\
\text { and/or opportunities to precept interns than RDNs } \\
\text { working part-time or per diem/other. }\end{array}$ \\
\hline $\begin{array}{l}\text { Commitment to the } \\
\text { Preceptor Role (scale) }\end{array}$ & 13 & $\begin{array}{l}\text { The higher the commitment, the more likely the } \\
\text { RDNs would be precepting. }\end{array}$ \\
\hline $\begin{array}{l}\text { Area Where Work (if not } \\
\text { working, reside) }\end{array}$ & 34 & $\begin{array}{l}\text { There may be more preceptors or rotation } \\
\text { opportunities in more densely populated area, such } \\
\text { as urban areas, and therefore may see less in rural } \\
\text { areas where there are fewer hospitals, fewer } \\
\text { preceptors, etc., where interns may be able to obtain } \\
\text { supervised practice experiences. }\end{array}$ \\
\hline $\begin{array}{l}\text { On DI advisory } \\
\text { committee }\end{array}$ & 39 & $\begin{array}{l}\text { RDNs on an advisory committee may be more } \\
\text { involved with interns and the process or may have a } \\
\text { higher interest area in working with interns; } \\
\text { therefore, may be more likely to be precepting. May } \\
\text { be a preceptor for a program and is how became } \\
\text { involved with the committee. }\end{array}$ \\
\hline Works for DI program & 39 & $\begin{array}{l}\text { RDNs working for a DI program may be more } \\
\text { involved with interns and the process, may have a } \\
\text { higher interest area in working with interns, or } \\
\text { possibly feel more obligated given their position and } \\
\text { therefore more likely to precept. }\end{array}$ \\
\hline
\end{tabular}




\section{Chapter IV}

\section{RESULTS}

\section{Brief Introduction}

This cross-sectional study presents findings related to potential incentives, benefits, support, satisfaction, commitment to the preceptor role, barriers, and factors associated with predicting RDNs who currently precept, as reported in this chapter. Data for this survey were obtained from an online survey of a national random sample of Registered Dietitian Nutritionists (RDNs).

\section{Study Flow}

The survey link, using Qualtrics software, was sent out to 9,066 RDN e-mail accounts. All 90,663 RDNs were assigned a random number; the random number column was sorted in ascending order and the first 9,066 RDNs were selected from the list, to make up the randomly selected sample of $10 \%$ of RDNs. A total of 335 e-mails bounced back and were not delivered (e.g., the server may have rejected it, e-mail address may no longer exist, mailbox may be full or server offline at moment sent). The principal investigator also received 12 e-mails from recipients with an explanation for why the e-mail respondent was not eligible to complete the survey (e.g., retired or e-mail was no longer the RDN's e-mail). 
About 1,370 surveys were opened from the survey link provided and of those, 1,261 agreed to the consent, confirmed they were an RDN, and completed the required question regarding preceptor status (Q4). A total of 1,170 RDNs completed at least one scale in the survey, for a $13.4 \%$ response rate. This was the final sample $(\mathrm{N}=1170)$ used for the data analysis, which consisted of 434 (37.1\%) current preceptors, 393 (33.6\%) former preceptors, and 343 never precepted (29.3\%). (See Figure 4.1 for study flow chart.)

\section{Characteristics of Registered Dietitian Nutritionists}

Table 4.1 includes the characteristics of the Registered Dietitian Nutritionist (RDN) survey respondents. Overall, respondents reported being an RDN for about 17 years (mean). The experience data did have a positive skew; to note, the median was 14 years. The former preceptors group reported being in the field about 21 years, significantly longer than current preceptors (15 years, difference > $.5 \mathrm{SD}$ ) and RDNs who have never precepted (16 years). There were 947 RDNs (80.9\%) currently working in the field. For current preceptors, $80.6 \%$ reported working full-time, which was significantly higher than expected from the chi square analysis, whereas working full-time dropped to $52.7 \%$ for former preceptors and $48.1 \%$ for the never precepted group - significantly less than expected. Twelve percent of current preceptors worked part-time and 1.4\% per diem/other-both significantly lower than would be expected. RDNs reported being in their current/recent positions for a mean of about 8 years and those who have experience precepting have precepted an average of 6.7 years. The years working in current, or most

recent, position data had a positive skew; to note, the median was 5 years. About $38 \%$ of 


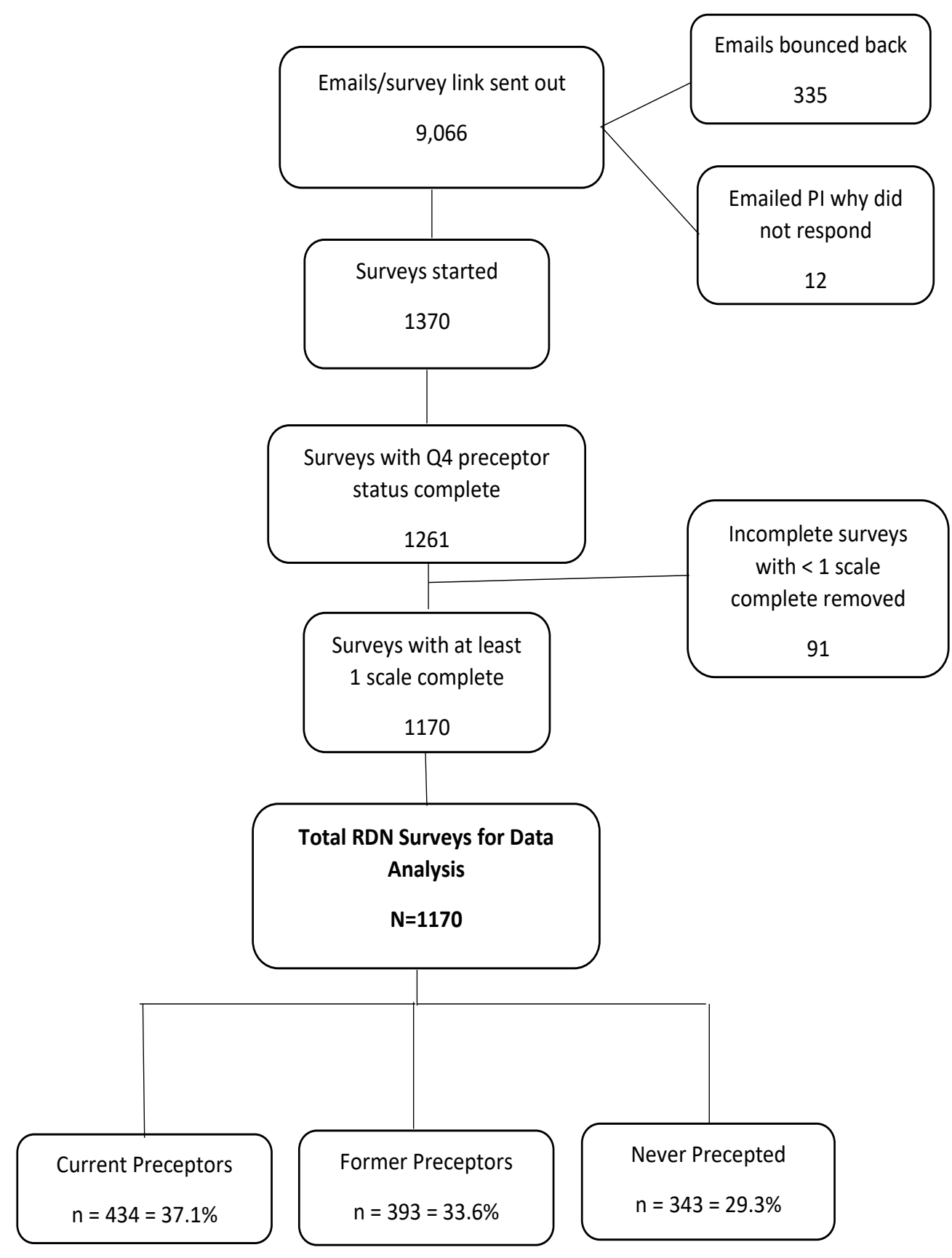

Figure 4.1. Study flow chart 
participants' highest degree was a bachelor's degree in a nutrition/dietetics-related field, $50 \%$ held a master's degree, and $2.5 \%$ had obtained their doctorate. Twenty-five percent held a specialization credential in the field, with the highest group reporting a specialization credential to be current preceptors at $34.1 \%$, significantly higher than expected. Among the credentials chosen by current preceptors, the largest group of respondents were Certified Nutrition Support Clinicians (7.8\%), significantly higher than expected. About 53\% of respondents were Academy of Nutrition and Dietetics (AND) members and $7 \%$ were members of the Nutrition and Dietetics Educators and Preceptors group of the AND. About 24\% held professional leadership positions in nutrition/ dietetics, with current preceptors reporting they held leadership positions significantly higher than expected (29.3\%), while the never group was significantly lower than expected (16.6\%). Approximately $17 \%$ of the RDNs were teaching outside of the preceptor role. Participants were mostly female (86.9\%) and identified as White nonHispanic, with a mean age of 44 years. The former preceptors were significantly older (48) than the current (41) and never (43) precepted groups. The age data did have a positive skew; to note, the median was 40 years.

There were $9(0.8 \%)$ Dietetic Internship (DI) Directors or Coordinators who responded, 2.4\% RDNs who indicated they worked for a DI program, $0.2 \%$ working for ACEND, $2.9 \%$ on a DI advisory committee, and $1.6 \%$ on a DI admissions committee. The current preceptors responded significantly higher than expected for working for a DI program $(5.1 \%)$ and being on a DI advisory committee $(5.8 \%)$. 
Table 4.1

Characteristics of Survey Participants

\begin{tabular}{|c|c|c|c|c|c|c|}
\hline & $\begin{array}{c}\text { Total } \\
\text { RDNs } \\
\mathrm{N}=\mathbf{1 1 7 0}\end{array}$ & $\begin{array}{c}\text { Current } \\
\text { Preceptors } \\
\text { n }=434 \\
(37.1 \%) \\
\end{array}$ & $\begin{array}{c}\text { Former } \\
\text { Preceptors } \\
\mathbf{n}=\mathbf{3 9 3} \\
(\mathbf{3 3 . 6 \% )} \\
\end{array}$ & $\begin{array}{c}\text { Never } \\
\text { Precepted } \\
\mathbf{n}=\mathbf{3 4 3} \\
(29.3 \%) \\
\end{array}$ & & $\mathbf{p}$ \\
\hline Years RDN/position & & & & & Welch F & \\
\hline $\begin{array}{l}\text { Yrs RDN } \\
\text { mean (SD) }\end{array}$ & $\begin{array}{c}17.32 \\
(12.23)\end{array}$ & $\begin{array}{c}14.9^{\mathrm{a}} \\
(11.38) \\
\end{array}$ & $\begin{array}{l}21.24^{\mathrm{b}} \\
(12.5)\end{array}$ & $\begin{array}{l}15.89^{\mathrm{a}} \\
(11.9)\end{array}$ & 28.881 & $.000 *$ \\
\hline $\begin{array}{l}\text { Yrs in current/recent } \\
\text { position mean (SD) }\end{array}$ & $\begin{array}{c}7.96 \\
(8.04)\end{array}$ & $\begin{array}{c}8.16 \\
(7.93)\end{array}$ & $\begin{array}{c}8.45 \\
(8.54)\end{array}$ & $\begin{array}{c}7.04 \\
(7.47)\end{array}$ & -- & .064 \\
\hline Years precepting & & & & & $\mathrm{t}$ & \\
\hline $\begin{array}{l}\text { Yrs precepting Dietetic } \\
\text { Interns } \\
\text { mean (SD) }\end{array}$ & $\begin{array}{c}6.73 \\
(6.33)\end{array}$ & $\begin{array}{l}7.85^{\mathrm{a}} \\
(6.63)\end{array}$ & $\begin{array}{c}5.5^{\mathrm{b}} \\
(5.74)\end{array}$ & NA & 5.210 & $.000^{*}$ \\
\hline $\begin{array}{l}\text { Currently working in } \\
\text { Nutrition/Dietetics }\end{array}$ & & & & & $\begin{array}{l}\chi^{2} \\
\text { Cramer's } \\
\text { V }\end{array}$ & \\
\hline $\begin{array}{l}\text { Full Time } \\
\%(\mathrm{n})\end{array}$ & $\begin{array}{c}61.7 \\
(722) \\
\end{array}$ & $\begin{array}{l}80.6^{* \mathrm{H}} \\
(350)\end{array}$ & $\begin{array}{l}52.7^{* \mathrm{~L}} \\
(207)\end{array}$ & $\begin{array}{l}48.1^{* \mathrm{~L}} \\
(165)\end{array}$ & & \\
\hline $\begin{array}{l}\text { Part Time } \\
\%(\mathrm{n})\end{array}$ & $\begin{array}{c}14.4 \\
(169)\end{array}$ & $\begin{array}{l}12.4^{* \mathrm{~L}} \\
(54)\end{array}$ & $\begin{array}{l}17.0 \\
(67)\end{array}$ & $\begin{array}{l}14.0 \\
(48)\end{array}$ & & \\
\hline $\begin{array}{l}\text { Per Diem/Other } \\
\%(\mathrm{n})\end{array}$ & $\begin{array}{l}4.8 \\
(56)\end{array}$ & $\begin{array}{c}1.4^{* \mathrm{~L}} \\
(6)\end{array}$ & $\begin{array}{l}6.9^{* \mathrm{H}} \\
(27)\end{array}$ & $\begin{array}{r}6.7^{* \mathrm{H}} \\
(23)\end{array}$ & & \\
\hline $\begin{array}{l}\text { Out of field } \leq 1 \mathrm{yr} \\
\%(\mathrm{n})\end{array}$ & $\begin{array}{c}2.4 \\
(28) \\
\end{array}$ & $\begin{array}{l}0^{*} \mathrm{~L} \\
(0)\end{array}$ & $\begin{array}{l}4.8^{* \mathrm{H}} \\
(19)\end{array}$ & $\begin{array}{l}2.6 \\
(9)\end{array}$ & & \\
\hline $\begin{array}{l}\text { Out of field > } 1 \mathrm{yr} \\
\%(\mathrm{n})\end{array}$ & $\begin{array}{c}7.1 \\
(83)\end{array}$ & $\begin{array}{c}0.7^{* \mathrm{~L}} \\
(3)\end{array}$ & $\begin{array}{l}9.9^{* \mathrm{H}} \\
(39)\end{array}$ & $\begin{array}{c}12.0^{* \mathrm{H}} \\
(41)\end{array}$ & $\begin{array}{c}116.814 \\
.235\end{array}$ & $.000^{*}$ \\
\hline $\begin{array}{l}\text { Highest Degree in } \\
\text { Nutrition/Dietetics- } \\
\text { related field }\end{array}$ & & & & & $\begin{array}{c}\chi^{2} \\
\text { Cramer's } \\
\text { V }\end{array}$ & \\
\hline $\begin{array}{l}\text { Bachelors } \\
\%(\mathrm{n})\end{array}$ & $\begin{array}{c}38.1 \\
(446)\end{array}$ & $\begin{array}{c}43.1 \\
(187)\end{array}$ & $\begin{array}{c}38.4 \\
(151) \\
\end{array}$ & $\begin{array}{c}31.5 \\
(108) \\
\end{array}$ & & \\
\hline $\begin{array}{l}\text { Masters } \\
\%(\mathrm{n})\end{array}$ & $\begin{array}{r}49.9 \\
(584) \\
\end{array}$ & $\begin{array}{l}50.9 \\
(221) \\
\end{array}$ & $\begin{array}{c}50.1 \\
(197) \\
\end{array}$ & $\begin{array}{c}48.4 \\
(166) \\
\end{array}$ & & \\
\hline $\begin{array}{l}\text { Doctorate } \\
\%(\mathrm{n})\end{array}$ & $\begin{array}{l}2.5 \\
(29) \\
\end{array}$ & $\begin{array}{l}1.2 \\
(5) \\
\end{array}$ & $\begin{array}{c}3.1 \\
(12) \\
\end{array}$ & $\begin{array}{c}3.5 \\
(12) \\
\end{array}$ & -- & .058 \\
\hline $\begin{array}{l}\text { Specialization Credential } \\
\text { in Nutrition/Dietetics- } \\
\text { related field }\end{array}$ & & & & & $\begin{array}{c}\chi^{2} \\
\text { Cramer's } \\
\text { V }\end{array}$ & \\
\hline $\begin{array}{l}\text { Yes } \\
\%(\mathrm{n})\end{array}$ & $\begin{array}{c}25.4 \\
(297)\end{array}$ & $\begin{array}{c}34.1^{* \mathrm{H}} \\
(148)\end{array}$ & $\begin{array}{c}21.9^{* \mathrm{~L}} \\
(86)\end{array}$ & $\begin{array}{c}18.4^{* \mathrm{~L}} \\
(63)\end{array}$ & & \\
\hline $\begin{array}{l}\text { No } \\
\%(\mathrm{n})\end{array}$ & $\begin{array}{c}64.8 \\
(758)\end{array}$ & $\begin{array}{l}60.6^{* \mathrm{~L}} \\
(263)\end{array}$ & $\begin{array}{l}69.5^{* \mathrm{H}} \\
(273)\end{array}$ & $\begin{array}{l}64.7^{* \mathrm{H}} \\
(222)\end{array}$ & $\begin{array}{c}20.824 \\
.140\end{array}$ & $.000 *$ \\
\hline $\begin{array}{l}\text { Advanced/board } \\
\text { practice cert in... }\end{array}$ & & & & & $\begin{array}{c}\chi^{2} \\
\text { Cramer's } \\
\mathrm{V}\end{array}$ & \\
\hline $\begin{array}{l}\text { Clinical Nutrition } \\
\%(\mathrm{n})\end{array}$ & $\begin{array}{l}0.3 \\
(4)\end{array}$ & $\begin{array}{l}0.5 \\
(2)\end{array}$ & $\begin{array}{l}0.3 \\
(1)\end{array}$ & $\begin{array}{l}0.3 \\
(1)\end{array}$ & -- & .976 \\
\hline
\end{tabular}




\begin{tabular}{|c|c|c|c|c|c|c|}
\hline & $\begin{array}{c}\text { Total } \\
\text { RDNs } \\
\mathbf{N}=\mathbf{1 1 7 0}\end{array}$ & $\begin{array}{c}\text { Current } \\
\text { Preceptors } \\
\mathbf{n}=\mathbf{4 3 4} \\
(37.1 \%)\end{array}$ & $\begin{array}{c}\text { Former } \\
\text { Preceptors } \\
\text { n= 393 } \\
(\mathbf{3 3 . 6 \% )}\end{array}$ & $\begin{array}{c}\text { Never } \\
\text { Precepted } \\
\text { n= 343 } \\
(\mathbf{2 9 . 3 \% )}\end{array}$ & & $\mathbf{p}$ \\
\hline $\begin{array}{l}\text { Pediatric Nutrition } \\
\%(\mathrm{n})\end{array}$ & $\begin{array}{c}1.4 \\
(16)\end{array}$ & $\begin{array}{c}2.5 \\
(11)\end{array}$ & $\begin{array}{l}1.3 \\
(5)\end{array}$ & $\begin{array}{c}0 \\
(0)\end{array}$ & -- & .089 \\
\hline $\begin{array}{l}\text { Gerontological } \\
\text { Nutrition \% (n) }\end{array}$ & $\begin{array}{c}1.5 \\
(17)\end{array}$ & $\begin{array}{l}1.6 \\
(7)\end{array}$ & $\begin{array}{l}1.5 \\
(6)\end{array}$ & $\begin{array}{l}1.2 \\
(4)\end{array}$ & -- & .753 \\
\hline $\begin{array}{l}\text { Obesity and Weight } \\
\text { Management } \% \text { (n) }\end{array}$ & $\begin{array}{c}0.9 \\
(10) \\
\end{array}$ & $\begin{array}{l}1.2 \\
(5)\end{array}$ & $\begin{array}{l}0.5 \\
(2)\end{array}$ & $\begin{array}{l}0.9 \\
(3)\end{array}$ & -- & .718 \\
\hline $\begin{array}{l}\text { Oncology Nutrition } \\
\%(\mathrm{n})\end{array}$ & $\begin{array}{c}1.2 \\
(14) \\
\end{array}$ & $\begin{array}{l}2.1 \\
(9) \\
\end{array}$ & $\begin{array}{l}1.3 \\
(5) \\
\end{array}$ & $\begin{array}{c}0 \\
0 \\
(0)\end{array}$ & -- & .138 \\
\hline $\begin{array}{l}\text { Renal Nutrition } \\
\%(\mathrm{n})\end{array}$ & $\begin{array}{c}1.2 \\
(14) \\
\end{array}$ & $\begin{array}{l}1.8 \\
(8)\end{array}$ & $\begin{array}{l}1.3 \\
(5)\end{array}$ & $\begin{array}{l}0.3 \\
(1)\end{array}$ & -- & .415 \\
\hline $\begin{array}{l}\text { Sports Dietetics } \\
\%(\mathrm{n})\end{array}$ & $\begin{array}{c}1.4 \\
(16) \\
\end{array}$ & $\begin{array}{l}1.8 \\
(8)\end{array}$ & $\begin{array}{l}1.0 \\
(4)\end{array}$ & $\begin{array}{l}1.2 \\
(4)\end{array}$ & -- & .902 \\
\hline $\begin{array}{l}\text { Certified Diabetes } \\
\text { Educator \% (n) }\end{array}$ & $\begin{array}{l}8.2 \\
(96)\end{array}$ & $\begin{array}{c}8.3 \\
(36)^{* \mathrm{~L}}\end{array}$ & $\begin{array}{c}8.1 \\
(32)\end{array}$ & $\begin{array}{c}8.2 \\
(28)^{* \mathrm{H}}\end{array}$ & $\begin{array}{l}9.499 \\
.179\end{array}$ & $.009 *$ \\
\hline $\begin{array}{l}\text { Certified Nutrition } \\
\text { Support Clinician } \\
\%(\mathrm{n})\end{array}$ & $\begin{array}{l}7.8 \\
(91)\end{array}$ & $\begin{array}{c}14.1^{* \mathrm{H}} \\
(61)\end{array}$ & $\begin{array}{l}5.1 \\
(20)\end{array}$ & $\begin{array}{c}2.9^{* \mathrm{~L}} \\
(10)\end{array}$ & $\begin{array}{c}16.461 \\
.235\end{array}$ & $.000 *$ \\
\hline $\begin{array}{l}\text { Other(s) } \\
\%(\mathrm{n})\end{array}$ & $\begin{array}{c}3.6 \\
(42)\end{array}$ & $\begin{array}{c}3.9 \\
(17)\end{array}$ & $\begin{array}{l}2.3 \\
(9)\end{array}$ & $\begin{array}{l}4.7^{* \mathrm{H}} \\
(16)\end{array}$ & $\begin{array}{l}8.390 \\
.168\end{array}$ & $.015^{*}$ \\
\hline Member of & & & & & $\begin{array}{c}\chi^{2} \\
\text { Cramer's } \\
\mathrm{V}\end{array}$ & \\
\hline $\begin{array}{l}\text { Academy of Nutrition } \\
\text { and Dietetics \% (n) }\end{array}$ & $\begin{array}{l}52.8 \\
(618)\end{array}$ & $\begin{array}{c}58.5 \\
(254)\end{array}$ & $\begin{array}{c}51.4 \\
(202)\end{array}$ & $\begin{array}{l}47.2 \\
(162)\end{array}$ & -- & .139 \\
\hline $\begin{array}{l}\text { Nutrition and Dietetics } \\
\text { Educators and } \\
\text { Preceptors \% (n) }\end{array}$ & $\begin{array}{c}7.1 \\
(83)\end{array}$ & $\begin{array}{c}9.0 \\
(39)\end{array}$ & $\begin{array}{l}6.6 \\
(26)\end{array}$ & $\begin{array}{c}5.2 \\
(18)\end{array}$ & -- & .154 \\
\hline $\begin{array}{l}\text { Hold Professional } \\
\text { Leadership Position in } \\
\text { Nutrition/Dietetics }\end{array}$ & & & & & $\begin{array}{c}\chi^{2} \\
\text { Cramer's } \\
\mathrm{V}\end{array}$ & \\
\hline $\begin{array}{l}\text { Yes } \\
\%(n)\end{array}$ & $\begin{array}{l}23.8 \\
(278)\end{array}$ & $\begin{array}{l}29.3^{* \mathrm{H}} \\
(127)\end{array}$ & $\begin{array}{l}23.9 \\
(94)\end{array}$ & $\begin{array}{l}16.6^{* \mathrm{~L}} \\
(57)\end{array}$ & $\begin{array}{c}10.184 \\
.098\end{array}$ & $.006^{*}$ \\
\hline $\begin{array}{l}\text { Teaching Outside } \\
\text { Preceptor Role }\end{array}$ & & & & & $\begin{array}{c}\chi^{2} \\
\text { Cramer's } \\
\mathrm{V}\end{array}$ & \\
\hline $\begin{array}{l}\text { Yes } \\
\%(\mathrm{n})\end{array}$ & $\begin{array}{c}16.7 \\
(195)\end{array}$ & $\begin{array}{l}14.7 \\
(64)\end{array}$ & $\begin{array}{l}18.8 \\
(74)\end{array}$ & $\begin{array}{l}16.6 \\
(57)\end{array}$ & --- & .145 \\
\hline $\begin{array}{l}\text { Dietetic Internship } \\
\text { related work... }\end{array}$ & & & & & $\begin{array}{c}\chi^{2} \\
\text { Cramer's } \\
\mathrm{V}\end{array}$ & \\
\hline $\begin{array}{l}\text { Dietetic Internship } \\
\text { (DI) Director or } \\
\text { Coordinator \% (n) }\end{array}$ & $\begin{array}{l}0.8 \\
(9)\end{array}$ & $\begin{array}{l}0.9 \\
(4)\end{array}$ & $\begin{array}{l}1.3 \\
(5)\end{array}$ & $\begin{array}{c}0 \\
(0)\end{array}$ & -- & .144 \\
\hline $\begin{array}{l}\text { Work for DI program } \\
\%(n)\end{array}$ & $\begin{array}{l}2.4 \\
(28)\end{array}$ & $\begin{array}{c}5.1 \\
(22)^{* \mathrm{H}}\end{array}$ & $\begin{array}{l}0.8 \\
(3)^{* L}\end{array}$ & $\begin{array}{c}0.9 \\
(3)^{* \mathrm{~L}}\end{array}$ & $\begin{array}{c}18.427 \\
.135\end{array}$ & $.000 *$ \\
\hline $\begin{array}{l}\text { Work for ACEND } \\
\%(\mathrm{n})\end{array}$ & $\begin{array}{l}0.2 \\
(2)\end{array}$ & $\begin{array}{l}0.2 \\
(1)\end{array}$ & $\begin{array}{l}0.3 \\
(1)\end{array}$ & $\begin{array}{c}0 \\
(0)\end{array}$ & -- & .130 \\
\hline
\end{tabular}




\begin{tabular}{|c|c|c|c|c|c|c|}
\hline & $\begin{array}{c}\text { Total } \\
\text { RDNs } \\
\mathbf{N}=1170\end{array}$ & $\begin{array}{c}\text { Current } \\
\text { Preceptors } \\
\text { n=434 } \\
(37.1 \%) \\
\end{array}$ & $\begin{array}{c}\text { Former } \\
\text { Preceptors } \\
\mathbf{n}=\mathbf{3 9 3} \\
(\mathbf{3 3 . 6 \% )} \\
\end{array}$ & $\begin{array}{c}\text { Never } \\
\text { Precepted } \\
\mathbf{n}=\mathbf{3 4 3} \\
(\mathbf{2 9 . 3 \% )}\end{array}$ & & $\mathbf{p}$ \\
\hline $\begin{array}{l}\text { On DI advisory } \\
\text { committee \% (n) }\end{array}$ & $\begin{array}{l}2.9 \\
(34)\end{array}$ & $\begin{array}{c}5.8 \\
(25)^{* \mathrm{H}} \\
\end{array}$ & $\begin{array}{l}1.0 \\
(4) \\
\end{array}$ & $\begin{array}{c}1.5 \\
(5)^{* \mathrm{~L}} \\
\end{array}$ & $\begin{array}{c}17.242 \\
.130 \\
\end{array}$ & $.000 *$ \\
\hline $\begin{array}{l}\text { On DI admissions } \\
\text { committee } \% \text { (n) }\end{array}$ & $\begin{array}{c}1.6 \\
(19)\end{array}$ & $\begin{array}{c}2.3 \\
(10) \\
\end{array}$ & $\begin{array}{l}1.3 \\
(5)\end{array}$ & $\begin{array}{l}1.2 \\
(4)\end{array}$ & -- & .497 \\
\hline $\begin{array}{l}\text { None of the above } \\
\text { apply \% (n) }\end{array}$ & $\begin{array}{c}80.5 \\
(942)\end{array}$ & $\begin{array}{c}80.6 \\
(350)^{* \mathrm{~L}}\end{array}$ & $\begin{array}{c}82.2 \\
(323)^{* \mathrm{H}}\end{array}$ & $\begin{array}{c}78.4 \\
(269)^{* \mathrm{H}}\end{array}$ & $\begin{array}{c}29.511 \\
.170 \\
\end{array}$ & $.000 *$ \\
\hline Age & & & & & Welch F & \\
\hline $\begin{array}{l}\text { Age in years } \\
\text { mean (SD) }\end{array}$ & $\begin{array}{c}43.69 \\
(13.12) \\
\end{array}$ & $\begin{array}{l}41.34^{\mathrm{a}} \\
(12.31) \\
\end{array}$ & $\begin{array}{l}47.57^{\mathrm{b}} \\
(13.12) \\
\end{array}$ & $\begin{array}{l}42.55^{\mathrm{a}} \\
(13.31) \\
\end{array}$ & 22.205 & $.000 *$ \\
\hline Gender & & & & & $\begin{array}{c}\chi^{2} \\
\text { Cramer's } \\
\text { V }\end{array}$ & \\
\hline $\begin{array}{l}\text { Female } \\
\%(\mathrm{n})\end{array}$ & $\begin{array}{c}86.9 \\
(1017) \\
\end{array}$ & $\begin{array}{c}91.5 \\
(397) \\
\end{array}$ & $\begin{array}{c}87.8 \\
(345) \\
\end{array}$ & $\begin{array}{c}80.2 \\
(275) \\
\end{array}$ & & \\
\hline $\begin{array}{l}\text { Male } \\
\%(\mathrm{n})\end{array}$ & $\begin{array}{c}2.8 \\
(33) \\
\end{array}$ & $\begin{array}{c}2.8 \\
(12) \\
\end{array}$ & $\begin{array}{c}3.3 \\
(13) \\
\end{array}$ & $\begin{array}{l}2.3 \\
(8) \\
\end{array}$ & & \\
\hline $\begin{array}{l}\text { Other } \\
\%(\mathrm{n})\end{array}$ & $\begin{array}{l}0.3 \\
(3) \\
\end{array}$ & $\begin{array}{c}0 \\
(0) \\
\end{array}$ & $\begin{array}{l}0.5 \\
(2) \\
\end{array}$ & $\begin{array}{l}0.3 \\
(1) \\
\end{array}$ & -- & .632 \\
\hline Ethnicity & & & & & $\begin{array}{c}\chi^{2} \\
\text { Cramer's } \\
\text { V }\end{array}$ & \\
\hline $\begin{array}{l}\text { Hispanic } \\
\%(\mathrm{n}) \\
\end{array}$ & $\begin{array}{l}4.5 \\
(53) \\
\end{array}$ & $\begin{array}{l}5.5 \\
(24) \\
\end{array}$ & $\begin{array}{c}4.6 \\
(18) \\
\end{array}$ & $\begin{array}{r}3.2 \\
(11) \\
\end{array}$ & & \\
\hline $\begin{array}{l}\text { Non-Hispanic } \\
\%(\mathrm{n})\end{array}$ & $\begin{array}{c}84.4 \\
(987)\end{array}$ & $\begin{array}{c}87.1 \\
(378)\end{array}$ & $\begin{array}{c}85.8 \\
(337) \\
\end{array}$ & $\begin{array}{c}79.3 \\
(272) \\
\end{array}$ & -- & .474 \\
\hline Race & & & & & $\begin{array}{c}\chi^{2} \\
\text { Cramer's } \\
\mathrm{V}\end{array}$ & \\
\hline $\begin{array}{l}\text { American Indian or } \\
\text { Alaskan Native } \% \text { (n) }\end{array}$ & $\begin{array}{l}0.3 \\
(4) \\
\end{array}$ & $\begin{array}{l}0.7 \\
(3) \\
\end{array}$ & $\begin{array}{l}0.3 \\
(1) \\
\end{array}$ & $\begin{array}{c}0 \\
(0) \\
\end{array}$ & & \\
\hline $\begin{array}{l}\text { Asian or Pacific } \\
\text { Islander \% (n) }\end{array}$ & $\begin{array}{c}3.2 \\
(38) \\
\end{array}$ & $\begin{array}{c}3.9 \\
(17) \\
\end{array}$ & $\begin{array}{c}3.3 \\
(13) \\
\end{array}$ & $\begin{array}{l}2.3 \\
(8) \\
\end{array}$ & & \\
\hline $\begin{array}{l}\text { Black } \\
\%(\mathrm{n})\end{array}$ & $\begin{array}{l}2.1 \\
(24)\end{array}$ & $\begin{array}{l}1.8 \\
(8)\end{array}$ & $\begin{array}{c}2.5 \\
(10) \\
\end{array}$ & $\begin{array}{l}1.7 \\
(6)\end{array}$ & & \\
\hline $\begin{array}{l}\text { White } \\
\%(\mathrm{n})\end{array}$ & $\begin{array}{c}81.4 \\
(952)\end{array}$ & $\begin{array}{c}86.2 \\
(374) \\
\end{array}$ & $\begin{array}{c}81.4 \\
(320) \\
\end{array}$ & $\begin{array}{c}75.2 \\
(258)\end{array}$ & & \\
\hline $\begin{array}{l}\text { Mixed } \\
\%(\mathrm{n})\end{array}$ & $\begin{array}{c}2.0 \\
(23) \\
\end{array}$ & $\begin{array}{l}1.2 \\
(5) \\
\end{array}$ & $\begin{array}{l}2.3 \\
(9) \\
\end{array}$ & $\begin{array}{l}2.6 \\
(9) \\
\end{array}$ & & \\
\hline $\begin{array}{l}\text { Other } \\
\%(\mathrm{n})\end{array}$ & $\begin{array}{l}0.5 \\
(6) \\
\end{array}$ & $\begin{array}{l}0.5 \\
(2) \\
\end{array}$ & $\begin{array}{l}0.8 \\
(3) \\
\end{array}$ & $\begin{array}{l}0.3 \\
(1)\end{array}$ & -- & .632 \\
\hline
\end{tabular}

$\%$ yes + no does not add up to 100 since percentage accounts for missing data.

$\mathrm{NA}=$ not asked. Pearson Chi-Square used for categorical data when greater than 2 x 2 table, Cramer's V noted when results are significant (effect size $.07=$ small, $.21=$ medium, $.35=$ large). For $2 \times 2$ tables Continuity Correction used and effect size note with phi coefficient value $(.10=$ small, $.30=$ medium, $.50=$ large $)$. Post-hoc Adjusted Residuals used $(\geq 2.0=\mathrm{H}=$ higher than expected, $\leq-2.0=\mathrm{L}=$ lower than expected). Means with differing superscripts $(\mathrm{a}, \mathrm{b}, \mathrm{c})$ within the same row are significantly different at the $\mathrm{p}<.05$ level based on post-hoc test.

Welch F test used to compare means for continuous variables when responses from 3 groups, post-hoc Games-Howell. T-test used to compare means for continuous variables when responses from 2 groups. * $\mathrm{p}<.05$ (Pallant, 2016).

$\mathrm{P}$ values are for overall difference across the tables. 
Table 4.2 includes information on the RDN participants' responses to questions regarding their own dietetic internship and preceptor experiences. Most (54\%) responded that they attended a college/university-based internship program, followed by a hospital/health care facility-based DI (22\%). There was $8.5 \%$ who reported they were in a distance learning DI program. The satisfaction they reported when they were interns with their own preceptors was 2.35 , falling between satisfied and very satisfied on the scale.

Table 4.2

RDNs' Own Dietetic Internship and Preceptor Experiences

$\begin{array}{ccccc}\text { Total } & \begin{array}{c}\text { Current } \\ \text { Preceptors }\end{array} & \begin{array}{c}\text { Former } \\ \text { Preceptors }\end{array} & \begin{array}{c}\text { Never } \\ \text { Precepted }\end{array} & \\ \text { RDNs } & \mathbf{n}=\mathbf{3 9 5} & \mathbf{n}=\mathbf{3 3 2} & \mathbf{n}=\mathbf{2 5 6} & \mathbf{p} \\ \mathrm{N}=\mathbf{9 9 4} & (\mathbf{4 0 . 2 \% )} & \mathbf{( 3 3 . 8 \% )} & \mathbf{( 2 6 . 0 \% )} & \end{array}$

\begin{tabular}{lccccc}
\hline RD was in a ... & & & & \multicolumn{1}{c}{$\chi^{2}$} \\
Cramer's V
\end{tabular}

Ns vary based on missing data.

${ }^{\#} 0=$ very dissatisfied to $3=$ very satisfied.

$\wedge$ In the post-hoc analysis no groups were significantly different than any other groups

Pearson Chi-Square used, Cramer's V noted (effect size $.07=$ small, $.21=$ medium, $.35=$ large). Post-hoc Adjusted Residuals used $(\geq 2.0=\mathrm{H}=$ higher than expected, $\leq-2.0=\mathrm{L}=$ lower than expected) (Pallant, 2016). $\mathrm{P}$ values are for overall difference across the tables.

Note: Company-based respondents may have a slightly lower number here since Sodexo was used for pilot and participants removed for main survey. 
Participants responded from all 50 states, Washington, DC, and Puerto Rico. The states with the greatest number of respondents included New York (6.8\%), California (6.6\%), Texas (6.1\%), Illinois (5.5\%), Pennsylvania (4.5\%), Florida (3.9\%), North Carolina (3.7\%), Minnesota (3.4\%), Ohio (3.4\%), Massachusetts (2.7\%), Virginia (2.6\%), Michigan (2.5\%), Washington (2.4\%), Tennessee (2.2\%), Colorado (2.1\%), New Jersey (2.1\%), Wisconsin (2.0\%), and Arizona (1.8\%). Participants worked, or if not working resided, in mostly urban areas (44.2\%), followed by suburban areas (33.1\%), as indicated in Table 4.3. Current preceptors worked/resided in urban areas significantly higher than expected (54.4\%), while never preceptors responded significantly lower than expected to be in urban areas (32.7\%) and significantly higher than expected in suburban $(35.6 \%)$ and rural areas $(12.2 \%)$.

Being a preceptor was not required but allowed for $53 \%$ of respondents and required for $21 \%$ of respondents, with current preceptors responding significantly higher than expected that it was required (42.9\%), with former (15.5\%) and never $(0 \%)$ responding significantly lower than expected. The last time former preceptors reported precepting was a mean of about 7 years ago and 59\% reported being eligible to precept, while only $25.7 \%$ reported they knew how to sign up again if they were willing and able to precept. Forty percent of RDNs who have never precepted reported they were eligible to precept. Yet only $17.5 \%$ of those who never precepted had ever been asked to precept and only $12 \%$ reported knowing how to sign up—significantly lower than expected. Twenty-one percent of never respondents reported that other RDNs at their most recent workplace have precepted dietetic interns in the last 12 months and 29\% of former 
preceptors reported other RDNs precepting in the past 12 months at their most recent place of employment.

Participants reported precepting a mean of about 7 years and current preceptors closer to 8 years, significantly higher than former preceptors (5.5 years). Typically, participants were precepting about 3.7 interns a year. Around $42-43 \%$ of current and former preceptors reported they were always the intern's primary preceptor and about $26-32 \%$ reported they were sometimes the primary preceptor. Typical weeks that interns were assigned to the RDN were 5, with a mean of about 28 hours per week, estimating a typical total of 140 hours per rotation. Close to $53 \%$ of current and former preceptors typically precepted interns in an inpatient clinical/Medical Nutrition Therapy setting, with the majority in a hospital setting (37-42\%). The next largest response for the typical rotation with the RDN was outpatient Medical Nutrition Therapy and community nutrition (30-32\% of current and former preceptors). Former preceptors typically supervised interns in nursing homes or transitional care units (14.2\%) and during research rotations (2.5) significantly higher than expected, while current preceptors usually precepted students in similar rotations, lower than expected $-9 \%$ and $1.6 \%$, respectively. The primary practice area for those who never precepted was health care (35\%).

All respondents were asked if they have received preceptor training and $22 \%$ responded yes while $69 \%$ responded no. 
Table 4.3

Characteristics of Preceptors, Rotations, and so on

\begin{tabular}{|c|c|c|c|c|c|c|}
\hline & $\begin{array}{c}\text { Total } \\
\text { RDNs } \\
\mathrm{N}=1170\end{array}$ & $\begin{array}{c}\text { Current } \\
\text { Preceptors } \\
\mathbf{n}=\mathbf{4 3 4} \\
(\mathbf{3 7 . 1 \%}) \\
\end{array}$ & $\begin{array}{c}\text { Former } \\
\text { Preceptors } \\
\mathbf{n}=\mathbf{3 9 3} \\
(\mathbf{3 3 . 6 \%}) \\
\end{array}$ & $\begin{array}{c}\text { Never } \\
\text { Precepted } \\
\mathbf{n}=\mathbf{3 4 3} \\
(\mathbf{2 9 . 3 \% )} \\
\end{array}$ & & $\mathbf{p}$ \\
\hline Preceptor characteristics & & & & & $\mathrm{t}$ & \\
\hline $\begin{array}{l}\text { Year precepting Dietetic } \\
\text { interns, mean (SD) }\end{array}$ & $\begin{array}{c}6.73 \\
(6.33) \\
\end{array}$ & $\begin{array}{r}7.85^{\mathrm{a}} \\
(6.63) \\
\end{array}$ & $\begin{array}{c}5.5^{\mathrm{b}} \\
(5.74) \\
\end{array}$ & NA & 5.210 & $.000 *$ \\
\hline $\begin{array}{l}\text { Typical number interns } \\
\text { precep(ed) / year, mean } \\
\text { (SD) }\end{array}$ & $\begin{array}{l}3.71 \\
(3.74)\end{array}$ & $\begin{array}{l}3.86 \\
(3.34)\end{array}$ & $\begin{array}{c}3.55 \\
(4.13)\end{array}$ & NA & -- & .257 \\
\hline $\begin{array}{l}\text { Area where work (if not } \\
\text { working where live) } \\
\text { Note: there were respondents } \\
\text { present from all } 50 \text { states, D.C. } \\
\text { and Puerto Rico }\end{array}$ & & & & & $\begin{array}{c}\chi^{2} \\
\text { Cramer's } \\
\mathrm{v}\end{array}$ & \\
\hline $\begin{array}{l}\text { Urban } \\
\%(\mathrm{n})\end{array}$ & $\begin{array}{c}44.2 \\
(517) \\
\end{array}$ & $\begin{array}{l}54.4^{* \mathrm{H}} \\
(236)\end{array}$ & $\begin{array}{c}43 \\
(169) \\
\end{array}$ & $\begin{array}{l}32.7^{* \mathrm{~L}} \\
(112)\end{array}$ & & \\
\hline $\begin{array}{l}\text { Suburban } \\
\%(\mathrm{n})\end{array}$ & $\begin{array}{c}33.1 \\
(387)\end{array}$ & $\begin{array}{l}30.9^{* \mathrm{~L}} \\
(134)\end{array}$ & $\begin{array}{c}33.3 \\
(131)\end{array}$ & $\begin{array}{l}35.6^{*} \mathrm{H} \\
(122)\end{array}$ & & \\
\hline $\begin{array}{l}\text { Rural } \\
\%(\mathrm{n}) \\
\end{array}$ & $\begin{array}{r}10.4 \\
(122) \\
\end{array}$ & $\begin{array}{l}7.6^{* \mathrm{~L}} \\
(33) \\
\end{array}$ & $\begin{array}{l}12.0 \\
(47)\end{array}$ & $\begin{array}{c}12.2^{*} \mathrm{H} \\
(42)\end{array}$ & & \\
\hline $\begin{array}{l}\text { Other } \\
\%(\mathrm{n})\end{array}$ & $\begin{array}{c}2.4 \\
(28)\end{array}$ & $\begin{array}{l}2.3 \\
(10)\end{array}$ & $\begin{array}{l}2.8 \\
(11)\end{array}$ & $\begin{array}{l}2.0 \\
(7)\end{array}$ & $\begin{array}{c}24.439 \\
.108\end{array}$ & $.000 *$ \\
\hline Being a Preceptor is/was... & & & & & $\begin{array}{c}\chi^{2} \\
\text { Cramer's } \\
\text { V }\end{array}$ & \\
\hline Not required but allowed & $\begin{array}{l}53.0 \\
(620) \\
\end{array}$ & $\begin{array}{l}52.5^{* \mathrm{~L}} \\
(228)\end{array}$ & $\begin{array}{c}64.1 * \mathrm{H} \\
(252)\end{array}$ & $\begin{array}{c}40.8^{* \mathrm{H}} \\
(140)\end{array}$ & & \\
\hline Required & $\begin{array}{c}21.1 \\
(247) \\
\end{array}$ & $\begin{array}{c}42.9^{* \mathrm{H}} \\
(186)\end{array}$ & $\begin{array}{c}15.5^{* \mathrm{~L}} \\
(61)\end{array}$ & $\begin{array}{l}0^{* \mathrm{~L}} \\
(0)\end{array}$ & $\begin{array}{c}123.132 \\
.377 \\
\end{array}$ & $.000 *$ \\
\hline $\begin{array}{l}\text { Not allowed or against } \\
\text { policy }\end{array}$ & -- & NA & $\begin{array}{c}8.1 \\
(32)\end{array}$ & $\begin{array}{c}7.3 \\
(25) \\
\end{array}$ & -- & -- \\
\hline $\begin{array}{l}\text { Not Applicable (e.g. not } \\
\text { currently working) }\end{array}$ & -- & NA & $\begin{array}{l}4.6 \\
(18) \\
\end{array}$ & $\begin{array}{l}18.7 \\
(64)\end{array}$ & -- & -- \\
\hline Preceptor status & & & & & $\begin{array}{c}\chi^{2} \\
\text { Continuity } \\
\text { Correction } \\
\text { Phi } \\
\end{array}$ & \\
\hline When last precepted & -- & NA & $\begin{array}{c}6.79 \\
(7.45) \\
\end{array}$ & NA & -- & -- \\
\hline $\begin{array}{l}\text { Eligible to precept } \\
\% \text { yes (n) }\end{array}$ & -- & NA & $\begin{array}{c}59 \\
(232) \\
\end{array}$ & $\begin{array}{c}40.2 \\
(138)\end{array}$ & -- & .215 \\
\hline $\begin{array}{l}\text { Ever asked to precept } \\
\% \text { yes (n) }\end{array}$ & -- & NA & NA & $\begin{array}{l}17.5 \\
(60) \\
\end{array}$ & -- & -- \\
\hline $\begin{array}{l}\text { Know how to sign up to } \\
\text { precept } \% \text { yes (n) }\end{array}$ & -- & NA & $\begin{array}{c}25.7^{* \mathrm{H}} \\
(101)\end{array}$ & $\begin{array}{c}12.0^{* \mathrm{~L}} \\
(41)\end{array}$ & $\begin{array}{c}16.379 \\
.165 \\
\end{array}$ & $.000^{*}$ \\
\hline
\end{tabular}




\begin{tabular}{|c|c|c|c|c|c|c|}
\hline & \multirow[b]{2}{*}{$\begin{array}{c}\text { Total } \\
\text { RDNs } \\
\text { N }=\mathbf{1 1 7 0}\end{array}$} & \multirow[b]{2}{*}{$\begin{array}{c}\text { Current } \\
\text { Preceptors } \\
\text { n=434 } \\
(37.1 \%) \\
\end{array}$} & \multirow[b]{2}{*}{$\begin{array}{c}\text { Former } \\
\text { Preceptors } \\
\text { n= 393 } \\
(\mathbf{3 3 . 6 \% )}\end{array}$} & \multirow[b]{2}{*}{$\begin{array}{c}\text { Never } \\
\text { Precepted } \\
\mathbf{n}=\mathbf{3 4 3} \\
(29.3 \%)\end{array}$} & \\
\hline & & & & & & $\mathbf{p}$ \\
\hline $\begin{array}{l}\text { Other RDNs at place of } \\
\text { work precept (last } 12 \text { mo) } \\
\% \text { yes }(n)\end{array}$ & -- & NA & $\begin{array}{c}29.0^{* \mathrm{H}} \\
(114)\end{array}$ & $\begin{array}{c}21.3^{* \mathrm{~L}} \\
(73)\end{array}$ & $\begin{array}{l}5.624 \\
.106\end{array}$ & $.018 *$ \\
\hline $\begin{array}{l}\text { Primary Preceptor for DIs' } \\
\operatorname{rotation}(\mathrm{s})\end{array}$ & & & & & $\begin{array}{c}\chi^{2} \\
\text { Cramer's } \\
\mathrm{V}\end{array}$ & \\
\hline $\begin{array}{l}\text { Yes, always } \\
\%(\mathrm{n})\end{array}$ & -- & $\begin{array}{c}43.3 \\
(188) \\
\end{array}$ & $\begin{array}{c}42.7 \\
(168) \\
\end{array}$ & NA & & \\
\hline $\begin{array}{l}\text { Yes, sometimes } \\
\%(\mathrm{n})\end{array}$ & -- & $\begin{array}{c}26.0 \\
(113)\end{array}$ & $\begin{array}{l}31.6 \\
(124)\end{array}$ & NA & & \\
\hline $\begin{array}{l}\text { No or not sure } \\
\%(\mathrm{n})\end{array}$ & -- & $\begin{array}{c}30.6 \\
(133) \\
\end{array}$ & $\begin{array}{c}25.4 \\
(100)\end{array}$ & NA & -- & .123 \\
\hline Typical Rotation with RDN & & & & & $\mathrm{t}$ & \\
\hline $\begin{array}{l}\text { Weeks per intern - mean } \\
(\mathrm{SD})\end{array}$ & -- & $\begin{array}{l}4.44^{\mathrm{a}} \\
(4.67)\end{array}$ & $\begin{array}{l}5.80^{\mathrm{b}} \\
(5.95)\end{array}$ & NA & 3.631 & $.000 *$ \\
\hline $\begin{array}{l}\text { Hours per week - mean } \\
(\mathrm{SD})\end{array}$ & -- & $\begin{array}{l}28.48^{\mathrm{a}} \\
(12.63) \\
\end{array}$ & $\begin{array}{c}26.5^{\mathrm{b}} \\
(12.80) \\
\end{array}$ & NA & 2.221 & $.027 *$ \\
\hline $\begin{array}{l}\text { Estimate typical total } \\
\text { hours during rotation } \\
\text { (based on above) }\end{array}$ & -- & 126.45 & 153.7 & NA & -- & -- \\
\hline $\begin{array}{l}\text { Rotation where typically } \\
\text { precept/precepted } \\
\% \text { yes }(n)\end{array}$ & & & & & $\begin{array}{l}\chi^{2} \\
\text { Continuity } \\
\text { Correction } \\
\text { Phi }\end{array}$ & \\
\hline $\begin{array}{l}\text { Inpatient Clinical/MNT } \\
\% \text { yes }(\mathrm{n})\end{array}$ & -- & $\begin{array}{l}52.8 \\
(229) \\
\end{array}$ & $\begin{array}{l}52.9 \\
(208) \\
\end{array}$ & NA & & \\
\hline $\begin{array}{l}\text { Outpatient MNT, } \\
\text { Community Nutrition \% } \\
\text { yes (n) }\end{array}$ & -- & $\begin{array}{c}31.6 \\
(137)\end{array}$ & $\begin{array}{l}30.3 \\
(119)\end{array}$ & NA & & \\
\hline $\begin{array}{l}\text { Food Service } \\
\text { Management } \\
\% \text { yes }(\mathrm{n}) \\
\end{array}$ & -- & $\begin{array}{c}6.2 \\
(27)\end{array}$ & $\begin{array}{l}6.4 \\
(25)\end{array}$ & NA & & \\
\hline $\begin{array}{l}\text { Research } \\
\% \text { yes }(n)\end{array}$ & -- & $\begin{array}{l}1.6 \\
(7)\end{array}$ & $\begin{array}{c}2.5 \\
(10)\end{array}$ & NA & -- & .910 \\
\hline \multicolumn{7}{|l|}{ Inpatient clinical areas: } \\
\hline $\begin{array}{l}\text { Hospital } \\
\% \text { yes }(\mathrm{n})\end{array}$ & -- & $\begin{array}{l}41.7 \\
(181)\end{array}$ & $\begin{array}{c}37.4 \\
(147) \\
\end{array}$ & NA & -- & .068 \\
\hline $\begin{array}{l}\text { Nursing Home, } \\
\text { Transitional } \\
\text { Care \% yes (n) }\end{array}$ & -- & $\begin{array}{l}9.0^{*} \mathrm{~L} \\
(39)\end{array}$ & $\begin{array}{c}14.2^{* \mathrm{H}} \\
(56)\end{array}$ & NA & $\begin{array}{l}5.834 \\
.121\end{array}$ & $.016^{*}$ \\
\hline $\begin{array}{l}\text { Rehabilitation } \\
\% \text { yes (n) }\end{array}$ & -- & $\begin{array}{c}2.3 \\
(10) \\
\end{array}$ & $\begin{array}{l}2.3 \\
(9) \\
\end{array}$ & NA & -- & 1.00 \\
\hline $\begin{array}{l}\text { Other } \\
\% \text { yes (n) }\end{array}$ & -- & $\begin{array}{l}1.6 \\
(7)\end{array}$ & $\begin{array}{c}3.1 \\
(12)\end{array}$ & NA & -- & .244 \\
\hline
\end{tabular}




\begin{tabular}{|c|c|c|c|c|c|c|}
\hline & $\begin{array}{c}\text { Total } \\
\text { RDNs } \\
\mathrm{N}=1170\end{array}$ & $\begin{array}{c}\text { Current } \\
\text { Preceptors } \\
\mathbf{n}=\mathbf{4 3 4} \\
(\mathbf{3 7 . 1 \% )} \\
\end{array}$ & $\begin{array}{c}\text { Former } \\
\text { Preceptors } \\
\mathbf{n}=\mathbf{3 9 3} \\
(\mathbf{3 3 . 6 \% )} \\
\end{array}$ & $\begin{array}{c}\text { Never } \\
\text { Precepted } \\
\mathbf{n}=\mathbf{3 4 3} \\
(29.3 \%)\end{array}$ & & $\mathbf{p}$ \\
\hline \multicolumn{7}{|l|}{$\begin{array}{l}\text { Primary Practice Area } \\
\text { (former and never } \\
\text { preceptors) }\end{array}$} \\
\hline $\begin{array}{l}\text { Health Care (i.e. clinical) } \\
\% \text { yes }(\mathrm{n})\end{array}$ & -- & NA & $\begin{array}{l}44.0 \\
(173) \\
\end{array}$ & $\begin{array}{l}35.0 \\
(120) \\
\end{array}$ & & \\
\hline $\begin{array}{l}\text { Community/Public Health } \\
\% \text { yes (n) }\end{array}$ & -- & NA & $\begin{array}{l}11.7 \\
(46)\end{array}$ & $\begin{array}{l}7.3 \\
(25) \\
\end{array}$ & & \\
\hline $\begin{array}{l}\text { Consultation, Private } \\
\text { Practice } \% \text { yes (n) }\end{array}$ & -- & NA & $\begin{array}{l}7.9 \\
(31)\end{array}$ & $\begin{array}{l}8.5 \\
(29)\end{array}$ & & \\
\hline $\begin{array}{l}\text { Academia (or } \\
\text { college/university faculty) } \\
\% \text { yes (n) }\end{array}$ & -- & NA & $\begin{array}{l}4.3 \\
(17)\end{array}$ & $\begin{array}{l}7.0 \\
(24)\end{array}$ & & \\
\hline $\begin{array}{l}\text { Business \& } \\
\text { Industry/Corporate } \\
\% \text { yes }(\mathrm{n})\end{array}$ & -- & NA & $\begin{array}{c}2.8 \\
(11)\end{array}$ & $\begin{array}{c}5.5 \\
(19)\end{array}$ & & \\
\hline $\begin{array}{l}\text { Government, Federal or } \\
\text { State Agency \% yes (n) }\end{array}$ & -- & NA & $\begin{array}{c}3.8 \\
(15) \\
\end{array}$ & $\begin{array}{c}4.4 \\
(15) \\
\end{array}$ & & \\
\hline $\begin{array}{l}\text { Wellness } \\
\% \text { yes }(n)\end{array}$ & -- & NA & $\begin{array}{c}3.8 \\
(15)\end{array}$ & $\begin{array}{c}4.1 \\
(14) \\
\end{array}$ & & \\
\hline $\begin{array}{l}\text { Food Service } \\
\% \text { yes }(\mathrm{n})\end{array}$ & -- & NA & $\begin{array}{c}2.8 \\
(11) \\
\end{array}$ & $\begin{array}{l}1.7 \\
(6)\end{array}$ & & \\
\hline $\begin{array}{l}\text { School Nutrition } \\
\% \text { yes (n) }\end{array}$ & -- & NA & $\begin{array}{c}2.8 \\
(11)\end{array}$ & $\begin{array}{l}0.9 \\
(3)\end{array}$ & & \\
\hline $\begin{array}{l}\text { Culinary } \\
\% \text { yes }(\mathrm{n})\end{array}$ & -- & NA & $\begin{array}{l}0.3 \\
(1)\end{array}$ & $\begin{array}{l}0.3 \\
(1)\end{array}$ & & \\
\hline $\begin{array}{l}\text { Communication/ } \\
\text { Publication }(\%) \\
\end{array}$ & -- & NA & $\begin{array}{c}0 \\
(0)\end{array}$ & $\begin{array}{l}0.3 \\
(1)\end{array}$ & & \\
\hline Other & - & NA & $\begin{array}{l}7.1 \\
(28)\end{array}$ & $\begin{array}{c}8.2 \\
(28)\end{array}$ & -- & .081 \\
\hline Perceptor Training & & & & & $\begin{array}{c}\chi^{2} \\
\text { Cramers } \\
\mathrm{V}\end{array}$ & \\
\hline $\begin{array}{l}\text { Received Training } \\
\text { Yes \% (n) }\end{array}$ & $\begin{array}{l}22.3 \\
(261) \\
\end{array}$ & $\begin{array}{l}38.9^{* \mathrm{H}} \\
(169)\end{array}$ & $\begin{array}{l}21.1 \\
(83)\end{array}$ & $\begin{array}{l}2.6^{* \mathrm{~L}} \\
(9)\end{array}$ & $\begin{array}{c}128.065 \\
.347 \\
\end{array}$ & $.000 *$ \\
\hline $\begin{array}{l}\text { Formal } \\
\text { Yes \% (n) }\end{array}$ & $\begin{array}{c}15.2 \\
(178)\end{array}$ & $\begin{array}{l}27.9 \\
(121)\end{array}$ & $\begin{array}{l}13.5 \\
(53)\end{array}$ & $\begin{array}{l}1.2 \\
(4)\end{array}$ & -- & -- \\
\hline $\begin{array}{l}\text { Informal } \\
\text { Yes \% (n) }\end{array}$ & $\begin{array}{c}15.8 \\
(185)\end{array}$ & $\begin{array}{c}27.4 \\
(119)\end{array}$ & $\begin{array}{c}15 \\
(59)\end{array}$ & $\begin{array}{c}2 \\
(7)\end{array}$ & -- & -- \\
\hline
\end{tabular}

$\%$ yes + no does not add up to 100 since percentage accounts for missing data.

Pearson Chi-Square used for categorical data when greater than $2 \times 2$ table, Cramer's V noted (effect size $.07=$ small, $.21=$ medium, $.35=$ large $)$. For $2 \times 2$ tables Continuity Correction used and effect size note with phi coefficient value $(.10=$ small, $.30=$ medium, $.50=$ large $)$. Post-hoc Adjusted Residuals used $(\geq 2.0=\mathrm{H}=$ higher than expected, $\leq-2.0=\mathrm{L}=$ lower than expected). Means with differing superscripts $(\mathrm{a}, \mathrm{b}, \mathrm{c})$ within the same row are significantly different at the $\mathrm{p}<.05$ level based on post-hoc test.

Welch $F$ test used to compare means for continuous variables when responses from 3 groups, post hoc Games-Howell.

T-test used to compare means for continuous variables when responses from 2 groups. $* \mathrm{p}<.05$ (Pallant, 2016). P values are for overall difference across the tables. 
Table 4.4 presents what RDNs reported they received for precepting, with the highest number of respondents reporting they did not receive any of the above for precepting $35.6 \%$ (416), followed by $9.3 \%$ receiving CPEUs for precepting, $7.7 \%$ receiving peer/public recognition, $7.3 \%$ CPEU offerings, $3.6 \%$ receiving a reduction in their regular workload, $2.6 \%$ receiving access to library resources, $2.2 \%$ pay or monetary compensation/gift card, and $2.1 \%$ hot topic/best practice updates.

Table 4.4

Received by RDNs for Precepting

\begin{tabular}{lc}
\cline { 2 - 2 } & $\begin{array}{c}\text { \% Yes (n) } \\
\mathbf{N}=\mathbf{7 9 9}\end{array}$ \\
\hline CPEUs for precepting & $9.3(109)$ \\
\hline Peer/public recognition & $7.7(90)$ \\
\hline CPEU offerings (not including for precepting itself) & $7.3(85)$ \\
\hline Reduction in my regular workload & $3.6(42)$ \\
\hline Access to library resources & $2.6(30)$ \\
\hline Pay or monetary compensation/gift card & $2.2(26)$ \\
\hline Hot topic/best practice updates & $2.1(25)$ \\
\hline Official designation/title for being a preceptor & $2.0(23)$ \\
\hline Tuition credit, waivers, discounts, or reimbursement & $1.7(20)$ \\
\hline Faculty appointment and/or faculty benefits/development & $1.6(19)$ \\
opportunities & $.9(11)$ \\
\hline Expenses paid toward a national conference & $.6(7)$ \\
\hline AND membership fee paid & $.3(3)$ \\
\hline CDR annual fee paid & $.2(2)$ \\
\hline DPG membership fee paid & $1.7(20)$ \\
\hline Other & $35.6(416)$ \\
\hline None of the above received for precepting (N=800)
\end{tabular}




\section{Research Q1}

\section{What incentivizes or motivates RDNs currently in the preceptor role to precept? What would motivate more RDNs to take on the preceptor role?}

Table 4.5 shows why current RDNs precept, why former RDNs precepted, and reasons RDNs who have never precepted would precept. The top five reasons overall, as well as for current and former preceptor groups (highlighted in the table in grey), included to contribute to the profession, to give back to the field, to introduce students and interns to the field, it is my professional responsibility, and to get experience teaching and mentoring. The top three were also shared by the never precepted group as well as the fifth reason, to get experience teaching and mentoring; the never group's fourth reason was to learn from the intern/keep up-to-date.

There was a statistically significant difference between the groups regarding their responses to seven of the reasons indicated. Of those that were significant, four of them were also the top four reasons specified for precepting, with current and former preceptors scoring higher than those who never precepted. These questions were: "to contribute to the future of the profession," "to give back to the field," "to introduce students and interns to the field," and "it is my professional responsibility." Current preceptors also scored higher than those who had never precepted for the reason "to network/stay connected." The two reasons with the overall lowest scores had statistically different scores for all three groups, with current scoring the highest, former in the middle, and never the lowest. These questions were: "it is required for my workplace" and "there are tangible benefits...." 
Three of the significant differences were greater than .5 SDs, making it a more meaningful difference. They were "it is my professional responsibility," the difference between current and never; and "there are tangible benefits...," the difference between former and current; as well as the difference between current and never, which was close to $1 \mathrm{SD}$ difference.

Table 4.5

Why RDNs Precept/Precepted/Would Precept Dietetic Interns

\begin{tabular}{|c|c|c|c|c|c|c|}
\hline & $\begin{array}{c}\text { Total } \\
\text { RDNs } \\
\text { N = 1072 } \\
\text { Mean (SD) }\end{array}$ & $\begin{array}{c}\text { Current } \\
\text { Preceptors } \\
n=\mathbf{4 2 0} \\
\text { mean (SD) }\end{array}$ & $\begin{array}{c}\text { Former } \\
\text { Preceptors } \\
n=369 \\
\text { mean }(\mathrm{SD})\end{array}$ & $\begin{array}{c}\text { Never } \\
\text { Precepted } \\
\mathbf{n}=\mathbf{2 8 0} \\
\text { mean (SD) }\end{array}$ & $\mathbf{F}$ & $\mathbf{p}$ \\
\hline \multicolumn{7}{|l|}{$\begin{array}{l}\text { Reasons I precept/ } \\
\text { precepted/would precept... }\end{array}$} \\
\hline $\begin{array}{l}\text { To contribute to the future of } \\
\text { the profession }\end{array}$ & $\begin{array}{l}4.02 \\
(.91) \\
\end{array}$ & $\begin{array}{l}4.12^{\mathrm{a}} \\
(.92) \\
\end{array}$ & $\begin{array}{l}4.09^{\mathrm{a}} \\
(.82)\end{array}$ & $\begin{array}{l}3.78^{\mathrm{b}} \\
(.97)\end{array}$ & 12.821 & $.000 *$ \\
\hline To give back to the field & $\begin{array}{l}3.95 \\
(.95)\end{array}$ & $\begin{array}{l}4.04^{\mathrm{a}} \\
(.95)\end{array}$ & $\begin{array}{l}4.02^{\mathrm{a}} \\
(.88)\end{array}$ & $\frac{3.73^{\mathrm{b}}}{(1.03)}$ & 9.569 & $.000 *$ \\
\hline $\begin{array}{l}\text { To introduce students and } \\
\text { interns to the field }\end{array}$ & $\begin{array}{l}3.94 \\
(.93)\end{array}$ & $\begin{array}{l}4.00^{\mathrm{a}} \\
(.97)\end{array}$ & $\begin{array}{l}4.04^{\mathrm{a}} \\
(.85)\end{array}$ & $\begin{array}{l}3.73^{\mathrm{b}} \\
(.95)\end{array}$ & 10.206 & $.000 *$ \\
\hline $\begin{array}{l}\text { It is my professional } \\
\text { responsibility }\end{array}$ & $\begin{array}{c}3.86 \\
(1.01) \\
\end{array}$ & $\begin{array}{l}4.06^{\mathrm{a}} \\
(.93) \\
\end{array}$ & $\begin{array}{l}3.97^{\mathrm{a}} \\
(.91) \\
\end{array}$ & $\begin{array}{l}3.41^{\mathrm{b}} \\
(1.09)\end{array}$ & 36.7 & $.000 *$ \\
\hline $\begin{array}{l}\text { To get experience teaching and } \\
\text { mentoring }\end{array}$ & $\begin{array}{c}3.68 \\
(1.09) \\
\end{array}$ & $\begin{array}{c}3.67 \\
(1.16) \\
\end{array}$ & $\begin{array}{c}3.67 \\
(1.11)\end{array}$ & $\begin{array}{l}3.70 \\
(.96)\end{array}$ & .064 & .938 \\
\hline $\begin{array}{l}\text { To learn from the intern/keep } \\
\text { up-to-date }\end{array}$ & $\begin{array}{c}3.39 \\
(1.18)\end{array}$ & $\begin{array}{c}3.33 \\
(1.24)\end{array}$ & $\begin{array}{c}3.37 \\
(1.18)\end{array}$ & $\begin{array}{c}3.49 \\
(1.07)\end{array}$ & 1.648 & .193 \\
\hline $\begin{array}{l}\text { Interns create positive change } \\
\text { for the department/organization }\end{array}$ & $\begin{array}{c}3.37 \\
(1.05)\end{array}$ & $\begin{array}{c}3.40 \\
(1.05)\end{array}$ & $\begin{array}{c}3.32 \\
(1.09)\end{array}$ & $\begin{array}{l}3.40 \\
(.98)\end{array}$ & .663 & .516 \\
\hline To network/stay connected & $\begin{array}{c}3.28 \\
(1.17) \\
\end{array}$ & $\begin{array}{l}3.22^{\mathrm{a}} \\
(1.25) \\
\end{array}$ & $\begin{array}{l}3.23^{\mathrm{ab}} \\
(1.14)\end{array}$ & $\begin{array}{l}3.43^{\mathrm{b}} \\
(1.07) \\
\end{array}$ & 3.49 & $.031 *$ \\
\hline $\begin{array}{l}\text { To screen potential employees } \\
\text { or job recruit }\end{array}$ & $\begin{array}{c}3.05 \\
(1.36)\end{array}$ & $\begin{array}{c}3.04 \\
(1.42)\end{array}$ & $\begin{array}{c}3.07 \\
(1.34)\end{array}$ & $\begin{array}{c}3.02 \\
(1.31)\end{array}$ & .156 & .856 \\
\hline $\begin{array}{l}\text { My personal relationship with } \\
\text { the DI Program/Director }\end{array}$ & $\begin{array}{c}2.53 \\
(1.51) \\
\end{array}$ & $\begin{array}{c}2.49 \\
(1.57) \\
\end{array}$ & $\begin{array}{c}2.60 \\
(1.61) \\
\end{array}$ & $\begin{array}{c}2.49 \\
(1.29) \\
\end{array}$ & .663 & .515 \\
\hline It is required by my workplace & $\begin{array}{c}1.98 \\
(1.78)\end{array}$ & $\begin{array}{l}2.46^{\mathrm{a}} \\
(1.91) \\
\end{array}$ & $\begin{array}{c}1.89^{\mathrm{b}} \\
(1.78)\end{array}$ & $\begin{array}{l}1.39^{\mathrm{c}} \\
(1.36)\end{array}$ & 37.68 & $.000 *$ \\
\hline $\begin{array}{l}\text { There are tangible benefits such } \\
\text { as, tuition credit, CE units, } \\
\text { monetary compensation, etc. }\end{array}$ & $\begin{array}{c}1.32 \\
(1.40)\end{array}$ & $\begin{array}{l}1.17^{\mathrm{a}} \\
(1.32)\end{array}$ & $\begin{array}{l}0.88^{\mathrm{b}} \\
(1.15)\end{array}$ & $\begin{array}{l}2.14^{\mathrm{c}} \\
(1.46)\end{array}$ & 71.908 & $.000 *$ \\
\hline
\end{tabular}

Ns vary based on missing data.

Scale $0=$ strongly disagree to $5=$ strongly agree;

Top 5 means in each highlighted.

Homogeneity of variances was violated, Levene test significant. Used Welch F test and Games Howell post-hoc analysis to correct for multiple tests. $* \mathrm{p}<0.05$. P values are for overall difference across the tables.

Means with differing superscripts $(a, b, c)$ within the same row are significantly different at the $p<.05$ level based on post hoc test. 
Potential incentives for precepting in Table 4.6 show the top five means overall (highlighted) to include CPEUs for precepting, followed by expenses paid toward a national conference, CDR annual fee paid, AND membership fee paid, and pay or monetary compensation/gift card. The incentive on the top of the list for current preceptors was expenses paid toward a national conference, and on the top of the list for former preceptors and never precepted was CPEUs for precepting. The lowest five means overall at the bottom of the list were faculty appointment and/or benefits/development opportunities, access to library resources, hot topic/best practice updates, official designation/title for being a preceptor, and peer/public recognition.

Of the 14 incentives listed, only two were found to have statistically significant differences in their responses between the groups: CPEUs for precepting, also the top incentive overall, and DPG membership fee paid, which was further down on the list. The mean score for RDNs who have currently precepted $(M=1.44)$ was significantly lower than the score for former preceptors $(\mathrm{M}=1.54)$ for CPEUs for precepting as a potential incentive, and current preceptors' mean score for DPG membership paid as a potential incentive $(M=1.15)$ was significantly higher than those who have never precepted $(M=$ .98). No statistically significant differences were found in the mean scores between former preceptors and those who have never precepted in relation to potential incentives. 
Table 4.6

Potential Incentives for Precepting, If Would Increase the Likelihood to Act as a Preceptor

\begin{tabular}{|c|c|c|c|c|c|c|}
\hline & $\begin{array}{c}\text { Total } \\
\text { RDNs } \\
\text { N = 1029 } \\
\text { Mean } \\
\text { (SD) }\end{array}$ & $\begin{array}{c}\text { Current } \\
\text { Preceptors } \\
\mathbf{n}=395 \\
\text { mean (SD) }\end{array}$ & $\begin{array}{c}\text { Former } \\
\text { Preceptors } \\
\mathbf{n}=347 \\
\text { mean (SD) }\end{array}$ & $\begin{array}{c}\text { Never } \\
\text { Precepted } \\
\mathbf{n}=\mathbf{2 8 3} \\
\text { mean (SD) }\end{array}$ & $\mathbf{F}$ & $\mathbf{p}$ \\
\hline $\begin{array}{l}\text { Continuing Professional } \\
\text { Education Units } \\
\text { (CPEUs) for precepting }\end{array}$ & $\begin{array}{l}1.52 \\
(.65)\end{array}$ & $\begin{array}{l}1.44^{\mathrm{a}} \\
(.68)\end{array}$ & $\begin{array}{l}1.59^{\mathrm{b}} \\
(.61)\end{array}$ & $\begin{array}{l}1.54^{\mathrm{ab}} \\
(.66)\end{array}$ & 5.611 & $.004^{*}$ \\
\hline $\begin{array}{l}\text { Expenses paid toward a } \\
\text { national conference }\end{array}$ & $\begin{array}{l}1.48 \\
(.72)\end{array}$ & $\begin{array}{l}1.50 \\
(.72)\end{array}$ & $\begin{array}{l}1.45 \\
(.74)\end{array}$ & $\begin{array}{l}1.47 \\
(.67)\end{array}$ & .357 & .700 \\
\hline $\begin{array}{l}\text { Commission of Dietetics } \\
\text { Registration annual fee } \\
\text { paid }\end{array}$ & $\begin{array}{l}1.41 \\
(.72)\end{array}$ & $\begin{array}{l}1.45 \\
(.72)\end{array}$ & $\begin{array}{l}1.37 \\
(.74)\end{array}$ & $\begin{array}{l}1.40 \\
(.71)\end{array}$ & 1.168 & .312 \\
\hline $\begin{array}{l}\text { Academy of Nutrition } \\
\text { and Dietetics } \\
\text { membership fee paid }\end{array}$ & $\begin{array}{l}1.34 \\
(.75)\end{array}$ & $\begin{array}{l}1.36 \\
(.76)\end{array}$ & $\begin{array}{l}1.31 \\
(.75)\end{array}$ & $\begin{array}{l}1.34 \\
(.75)\end{array}$ & .529 & .589 \\
\hline $\begin{array}{l}\text { Pay or monetary } \\
\text { compensation/gift card }\end{array}$ & $\begin{array}{l}1.32 \\
(.76) \\
\end{array}$ & $\begin{array}{l}1.35 \\
(.78) \\
\end{array}$ & $\begin{array}{l}1.29 \\
(.76) \\
\end{array}$ & $\begin{array}{l}1.33 \\
(.71) \\
\end{array}$ & .651 & .522 \\
\hline $\begin{array}{l}\text { CPEU offerings (not } \\
\text { including for precepting } \\
\text { itself) }\end{array}$ & $\begin{array}{l}1.25 \\
(.72)\end{array}$ & $\begin{array}{l}1.24 \\
(.71)\end{array}$ & $\begin{array}{l}1.27 \\
(71)\end{array}$ & $\begin{array}{l}1.24 \\
(.76)\end{array}$ & .201 & .818 \\
\hline $\begin{array}{l}\text { Tuition credit, waivers, } \\
\text { discounts, or } \\
\text { reimbursement }\end{array}$ & $\begin{array}{l}1.18 \\
(.80)\end{array}$ & $\begin{array}{l}1.19 \\
(.82)\end{array}$ & $\begin{array}{l}1.17 \\
(.80)\end{array}$ & $\begin{array}{l}1.17 \\
(.77)\end{array}$ & .055 & .946 \\
\hline $\begin{array}{l}\text { Dietetic Practice Group } \\
\text { membership fee paid }\end{array}$ & $\begin{array}{l}1.06 \\
(.80)\end{array}$ & $\begin{array}{l}1.15^{\mathrm{a}} \\
(.79)\end{array}$ & $\begin{array}{l}1.03^{\mathrm{ab}} \\
(.82)\end{array}$ & $\begin{array}{l}0.98^{\mathrm{b}} \\
(.77)\end{array}$ & 4.797 & $.009^{*}$ \\
\hline $\begin{array}{l}\text { Reduction in my regular } \\
\text { workload }\end{array}$ & $\begin{array}{l}1.03 \\
(.77)\end{array}$ & $\begin{array}{l}1.07 \\
(.76)\end{array}$ & $\begin{array}{l}1.00 \\
(.80)\end{array}$ & $\begin{array}{l}1.00 \\
(.75)\end{array}$ & 1.195 & .303 \\
\hline $\begin{array}{l}\text { Faculty appointment } \\
\text { and/or faculty } \\
\text { benefits/development } \\
\text { opportunities }\end{array}$ & $\begin{array}{l}0.99 \\
(.81)\end{array}$ & $\begin{array}{l}1.03 \\
(.82)\end{array}$ & $\begin{array}{l}0.96 \\
(.81)\end{array}$ & $\begin{array}{l}0.98 \\
(.78)\end{array}$ & .697 & .498 \\
\hline $\begin{array}{l}\text { Access to library } \\
\text { resources }\end{array}$ & $\begin{array}{l}0.90 \\
(.77)\end{array}$ & $\begin{array}{l}0.90 \\
(.78)\end{array}$ & $\begin{array}{l}0.87 \\
(.77)\end{array}$ & $\begin{array}{l}0.95 \\
(.76)\end{array}$ & .849 & .428 \\
\hline $\begin{array}{l}\text { Hot topic/best practice } \\
\text { updates }\end{array}$ & $\begin{array}{l}0.78 \\
(.72) \\
\end{array}$ & $\begin{array}{l}0.77 \\
(.74) \\
\end{array}$ & $\begin{array}{l}0.78 \\
(.74) \\
\end{array}$ & $\begin{array}{l}0.79 \\
(.68) \\
\end{array}$ & .081 & .922 \\
\hline $\begin{array}{l}\text { Official designation/title } \\
\text { for being a preceptor }\end{array}$ & $\begin{array}{l}0.74 \\
(.75)\end{array}$ & $\begin{array}{l}0.74 \\
(.76) \\
\end{array}$ & $\begin{array}{l}0.75 \\
(.76)\end{array}$ & $\begin{array}{l}0.73 \\
(.72) \\
\end{array}$ & .038 & .963 \\
\hline Peer/public recognition & $\begin{array}{l}0.72 \\
(.71)\end{array}$ & $\begin{array}{l}0.73 \\
(.72)\end{array}$ & $\begin{array}{l}0.77 \\
(.74)\end{array}$ & $\begin{array}{l}0.66 \\
(.66)\end{array}$ & 2.056 & .129 \\
\hline
\end{tabular}

Ns vary based on missing data.

Scale: $0=$ not very likely, $1=$ somewhat likely, 2 = very likely.

Top 5 means in each highlighted.

Homogeneity of variances was violated, Levene test significant. Used Welch F test and Games Howell post-hoc analysis to correct for multiple tests. ${ }^{*} \mathrm{p}<0.05$. P values are for overall difference across the tables.

Means with differing superscripts $(a, b, c)$ within the same row are significantly different at the $\mathrm{p}<.05$ level based on post-hoc test. 
Satisfaction with the incentives offered/received for precepting in Table 4.7

indicated that overall RDNs somewhat disagreed (1.98) that they were "satisfied with the incentives offered/received for precepting." Never had a mean of 2.19, scoring significantly higher than current (1.92) and former (1.90).

Table 4.7

Satisfaction With Precepting

\begin{tabular}{|c|c|c|c|c|c|c|}
\hline & $\begin{array}{c}\text { Total } \\
\text { RDNs } \\
\text { N = 1034 } \\
\text { Mean } \\
\text { (SD) }\end{array}$ & $\begin{array}{c}\text { Current } \\
\text { Preceptors } \\
n=410 \\
\text { mean (SD) }\end{array}$ & $\begin{array}{c}\text { Former } \\
\text { Preceptors } \\
\mathbf{n}=\mathbf{3 5 9} \\
\text { mean (SD) }\end{array}$ & $\begin{array}{c}\text { Never } \\
\text { Precepted } \\
\mathbf{n}=\mathbf{2 6 5} \\
\text { mean (SD) }\end{array}$ & $\mathbf{F}$ & $\mathbf{p}$ \\
\hline $\begin{array}{l}\text { I am satisfied with the } \\
\text { incentives } \\
\text { offered/received for } \\
\text { precepting }\end{array}$ & $\begin{array}{c}1.98 \\
(.042)\end{array}$ & $\begin{array}{c}1.92^{\mathrm{a}} \\
(1.37)\end{array}$ & $\begin{array}{c}1.90^{\mathrm{a}} \\
(1.42)\end{array}$ & $\begin{array}{l}2.19^{b} \\
(1.23)\end{array}$ & 4.685 & $.010^{*}$ \\
\hline
\end{tabular}

Scale: 0 = Strongly Disagree, 1 = Disagree, 2 = Somewhat Disagree, $3=$ Somewhat Agree, 4 = Agree, $5=$ Strongly Agree.

Robust Tests of Equality of Means (Welch), Post Hoc Games-Howell. * p $<0.05$.

Means with differing superscripts $(a, b, c)$ within the same row are significantly different at the $\mathrm{p}<.05$ level based on post-hoc test.

In Table 4.8, overall, the largest number of respondents $(25.6 \%)$ chose that they would precept with or without receiving continuing education $(\mathrm{CE})$ credits for precepting, when asked if CE credit for precepting would make them more likely to precept; this was followed by $23.8 \%$ of respondents overall choosing yes, receiving CE credits somewhat increases their likelihood to precept, and $22.6 \%$ chose maybe, if they could receive more than three credits a year. The least chosen response overall (7.4\%) was yes, receiving $\mathrm{CE}$ credits for precepting greatly increases my likelihood to precept.

A chi-square test for independence indicated a significant association between preceptor status and whether receiving continuing education credit for precepting would make the RDN more likely to precept. Current preceptors (36.6\%) responded significantly higher than expected that they would precept with or without CE credits, 
while never RDNs (12.0\%) responded significantly lower than expected. Never

preceptors' primary response to this question was maybe, if I could receive more than

three credits a year (27.4\%), which was significantly higher than expected. The response, including no number of $\mathrm{CE}$ credits would make it more likely for me to precept, was chosen significantly higher than expected for the never RDNs (13.4\%) and significantly lower than expected for the current preceptors $(6.0 \%)$.

When the RDNs were asked if they knew they could receive continuing education credit for precepting prior to this survey question, just over a quarter (26.2\%) said yes. Current preceptors $(45.4 \%)$ responded yes, significantly higher than expected, while former $(17 \%)$ and never $(12.5 \%)$ responded yes significantly lower than expected.

Table 4.8

Continuing Education Credit for Precepting

\begin{tabular}{|c|c|c|c|c|c|c|}
\hline & $\begin{array}{c}\text { Total } \\
\text { RDNs }\end{array}$ & $\begin{array}{c}\text { Current } \\
\text { Preceptors }\end{array}$ & $\begin{array}{c}\text { Former } \\
\text { Preceptors }\end{array}$ & $\begin{array}{c}\text { Never } \\
\text { Precepted }\end{array}$ & $\begin{array}{c}\text { Chi- } \\
\text { Square }\end{array}$ & $\mathbf{p}$ \\
\hline Response to Q below ${ }^{\#}$ & $\mathrm{~N}=1047$ & $(n=412)$ & $(\mathrm{n}=355)$ & $(\mathrm{n}=280)$ & & \\
\hline $\begin{array}{l}\text { Not applicable: I would } \\
\text { precept with or without CE } \\
\text { credits }\end{array}$ & $\begin{array}{l}25.6 \\
(299)\end{array}$ & $\begin{array}{c}36.6^{* \mathrm{H}} \\
(159)\end{array}$ & $\begin{array}{l}25.2 \\
(99)\end{array}$ & $\begin{array}{c}12.0 * \mathrm{~L} \\
(41)\end{array}$ & & \\
\hline $\begin{array}{l}\text { Yes, receiving CE credits } \\
\text { somewhat increases my } \\
\text { likelihood to precept }\end{array}$ & $\begin{array}{l}23.8 \\
(278)\end{array}$ & $\begin{array}{l}25.8 \\
(112)\end{array}$ & $\begin{array}{l}22.4 \\
(88)\end{array}$ & $\begin{array}{l}22.7 \\
(78)\end{array}$ & & \\
\hline $\begin{array}{l}\text { Maybe, if I could receive } \\
\text { more than } 3 \text { credits a year }\end{array}$ & $\begin{array}{l}22.6 \\
(264) \\
\end{array}$ & $\begin{array}{c}18.4 * \mathrm{~L} \\
(80)\end{array}$ & $\begin{array}{l}22.9 \\
(90) \\
\end{array}$ & $27.4 * \mathrm{H}(94)$ & & \\
\hline $\begin{array}{l}\text { No, no amount of CE } \\
\text { credits would make it more } \\
\text { likely for me to precept }\end{array}$ & $\begin{array}{c}10.2 \\
(119)\end{array}$ & $\begin{array}{c}6.0 * \mathrm{~L} \\
(26)\end{array}$ & $\begin{array}{l}12.0 \\
(47)\end{array}$ & $13.4 * \mathrm{H}(46)$ & & \\
\hline $\begin{array}{l}\text { Yes, receiving CE credits } \\
\text { greatly increases my } \\
\text { likelihood to precept }\end{array}$ & $\begin{array}{c}7.4 \\
(87)\end{array}$ & $\begin{array}{c}8.1 \\
(35)\end{array}$ & $\begin{array}{c}7.9 \\
(31)\end{array}$ & $\begin{array}{l}6.1 \\
(21)\end{array}$ & 64.461 & .000 \\
\hline $\begin{array}{l}\text { If RDN knew could receive } \\
\text { CE credits for precepting }\end{array}$ & $\mathrm{N}=1056$ & $(n=413)$ & $(n=360)$ & $(n=283)$ & & \\
\hline$\%$ Yes (n) & $\begin{array}{c}26.2 \\
(307)\end{array}$ & $\begin{array}{c}45.4 * \mathrm{H} \\
(197) \\
\end{array}$ & $\begin{array}{c}17.0 * \mathrm{~L} \\
(67) \\
\end{array}$ & $\begin{array}{c}12.5 * \mathrm{~L} \\
(43) \\
\end{array}$ & 115.036 & .000 \\
\hline
\end{tabular}

\footnotetext{
\# Knowing that you can receive continuing education (CE) credit for precepting (leadership activity type, 3 credits max/year), would that make you more likely to precept?

Cell contents: Count. Pearson Chi-Square. Cramer's V Q1 $=.175$ (closest to medium effect size a although slightly under (Pallant, 2016, p. 222), Cramer's V Q2 $=.330$. Post-hoc Adjusted Residuals used $(\geq 2.0=\mathrm{H}=$ higher than expected, $\leq-2.0=\mathrm{L}=$ lower than expected).

$* \mathrm{p}<.05$. P values are for overall difference across the tables.
} 
In Table 4.9, when RDNs were asked if they would precept if it was solely their decision, 66.9\% said yes. Over half the respondents in all three groups answered yes. A chi-square test for independence indicated a significant association between preceptor status and if they would precept if it was solely their decision, with current preceptors (82\%) responding yes significantly higher than expected and former $(61.3 \%)$ and never respondents (54.2\%) responding yes significantly lower than expected.

Table 4.9

If It Was Solely the RDNs' Decision, Would They Precept?

\begin{tabular}{lcccccc}
\cline { 2 - 6 } & $\begin{array}{c}\text { Total } \\
\text { RDNs } \\
\mathbf{N}=\mathbf{1 0 2 1}\end{array}$ & $\begin{array}{c}\text { Current } \\
\text { Preceptors } \\
(\mathbf{n = 4 0 5})\end{array}$ & $\begin{array}{c}\text { Former } \\
\text { Preceptors } \\
(\mathbf{n = 3 4 3})\end{array}$ & $\begin{array}{c}\text { Never } \\
\text { Precepted } \\
(\mathbf{n = 2 7 3})\end{array}$ & $\begin{array}{c}\text { Chi- } \\
\text { Square } \\
\text { Cramer's } \\
\text { V }\end{array}$ & p \\
\hline $\begin{array}{l}\text { If solely your } \\
\text { decision, would you } \\
\text { precept? }\end{array}$ & & & & & & \\
\hline \multicolumn{1}{c}{ \%es (n) } & 66.9 & $82.0 * \mathrm{H}$ & $61.3 * \mathrm{~L}$ & $54.2 * \mathrm{~L}$ & 47.588 & $.000 *$ \\
& $(783)$ & $(356)$ & $(241)$ & $(186)$ & .216 & \\
\hline
\end{tabular}

Cell contents: Count. Pearson Chi-Square. Cramer's V =.216 (medium effect size). Post-hoc Adjusted Residuals used $(\geq 2.0=\mathrm{H}=$ higher than expected, $\leq-2.0=\mathrm{L}=$ lower than expected) (Pallant, 2016).

$* \mathrm{p}<.05$

In Table 4.10, when RDNs were asked if they were involved in the final decision to precept or not to precept, $37.2 \%$ said yes. A chi-square test for independence indicated there was a significant association between preceptor status and whether the RDN was involved in the final decision to precept or not to precept. The current preceptors (53\%) responded significantly higher than expected that they were involved in the final decision to precept, while the never group (9.9\%) responded significantly lower than expected. 
Table 4.10

RDN Involved in Final Decision to Precept or Not to Precept

\begin{tabular}{lcccccc}
\cline { 2 - 6 } & $\begin{array}{c}\text { Total } \\
\text { RDNs } \\
\mathbf{N = 8 4 3}\end{array}$ & $\begin{array}{c}\text { Current } \\
\text { Preceptors } \\
(\mathbf{n = 3 9 5})\end{array}$ & $\begin{array}{c}\text { Former } \\
\text { Preceptors } \\
(\mathbf{n = 3 0 2})\end{array}$ & $\begin{array}{c}\text { Never } \\
\text { Precepted } \\
(\mathbf{n = 1 4 6})\end{array}$ & $\begin{array}{c}\text { Chi- } \\
\text { Square } \\
\text { Cramer's } \\
\mathbf{V}\end{array}$ & p \\
\hline $\begin{array}{l}\text { Involved in final } \\
\text { decision to precept, } \\
\text { or not to precept }\end{array}$ & & & & & & \\
\hline \multicolumn{1}{c}{ \% Yes (n) } & 37.2 & $53.0 * \mathrm{H}$ & 43.5 & $9.9 * \mathrm{~L}$ & 56.859 & $.000^{*}$ \\
& $(435)$ & $(230)$ & $(171)$ & $(34)$ & .260 & \\
\hline
\end{tabular}

Missing data high for this Q (327) was asked of all 3 groups. Cell contents: Count. Pearson Chi-Square. Cramer's V= .260 (medium effect size). Post-hoc Adjusted Residuals used $(\geq 2.0=\mathrm{H}=$ higher than expected, $\leq-2.0=\mathrm{L}=$ lower than expected) (Pallant, 2016).

$* \mathrm{p}<.05$. $\mathrm{P}$ values are for overall difference across the tables.

An independent-samples t-test was conducted (see Table 4.11) to compare former and never precepted responses to the statement, "I would be more likely to precept if I had access to an On-Call Specialist." On the 0-5 scale, there was a significant difference found in the means, with those who have never precepted $(1.94, \sim$ somewhat agree) responding lower than former preceptors $(2.73, \sim$ somewhat disagree).

Table 4.11

Responses From Former and Never Preceptors Regarding Access to an On-Call Specialist

\begin{tabular}{|c|c|c|c|c|c|}
\hline $\begin{array}{c}\text { Total } \\
\text { RDNs } \\
\text { N }=642 \\
\text { Mean } \\
\text { (SD) }\end{array}$ & $\begin{array}{c}\text { Current } \\
\text { Preceptors } \\
\text { n = NA } \\
\text { mean (SD) }\end{array}$ & $\begin{array}{c}\text { Former } \\
\text { Preceptors } \\
\text { n = } \mathbf{3 6 3} \\
\text { mean (SD) }\end{array}$ & $\begin{array}{c}\text { Never } \\
\text { Precepted } \\
\text { n= } 279 \\
\text { mean (SD) }\end{array}$ & $\mathbf{t}$ & $\mathbf{p}$ \\
\hline -- & NA & $\begin{array}{c}2.73^{\mathrm{a}} \\
(1.37)\end{array}$ & $\begin{array}{c}1.94^{\mathrm{b}} \\
(1.30)\end{array}$ & -7.442 & $.000 *$ \\
\hline
\end{tabular}

I would be more likely to precept if I had access to an On-Call Specialist...

Independent-samples t-test, equal variances not assumed.

Score $0=$ strongly agree, $1=$ agree, $2=$ somewhat agree, $3=$ somewhat disagree, $4=$ disagree, $5=$ strongly disagree. Ns vary based on missing data.

$\mathrm{NA}=$ not asked. $* \mathrm{p}<.05$ (2-tailed).

Means with differing superscripts $(a, b, c)$ within the same row are significantly different at the $p<.05$ level based on post-hoc test. 


\section{Research Question 2}

\section{What are the barriers to precepting for RDNs?}

Barriers to precepting for RDNs are shown in Table 4.12. The top barrier means included increased stress from having interns (3.10), time-consuming/increased workload (3.04), and a lack of incentives (2.77). The top three barriers were also the barriers with means of greater than 2.5 (midpoint on scale) for current and former respondents, while the mean scores of 11 of the barriers for RDNs who never precepted were greater than 2.5, as highlighted under the Never column in the table.

Of the 23 barriers listed, 20 were found to have statistically significant differences in their responses between the groups. This included the top three barriers. Barriers were scored on a 0-5 scale, with higher scores indicating more of a barrier.

For the top barrier, "increased stress from having interns," a post-hoc comparison indicated that the mean for former preceptors (2.77) was significantly lower than the mean scores for current (3.30) and never (3.22). This was also the case for the second highest barrier, "time-consuming/increased workload"-former (2.75) was significantly lower than current (3.16) and never (3.23) — as well as for the barrier "quality of the intern"-former (1.77) was significantly lower than current (2.05) and never (2.11).

For 12 of the barriers, including the barrier that scored third highest, the mean scores for RDNs who never precepted were significantly higher than the mean scores for former and never preceptors. The difference between current and never, as well as former and never, for the barrier lack of preceptor training was meaningfully different (> .5 SD). Five of the barriers later in the list also had significantly different means, with the 
differences found between all three groups. The differences across the five barriers all indicated higher scores in the never group, followed by the former and lowest scores for current preceptors. These five barriers were: legal issues; liability/regulatory concerns; length of intern onboarding process; restricted by the facility or management; and not enough for interns to do at my workplace, with many of the differences equaling greater than .5 SDs. The largest significant difference was found between current and never, as well as former and never, for the barrier related to being unfamiliar with an internship program, with a difference of $>1 \mathrm{SD}$.

The three barriers where the groups responded similarly, with no statistically significant differences found in responses, were: short-staffed or downsizing, lack of appreciation/recognition, and negative experience with internship program/prior intern.

Cronbach's alpha was conducted (not shown in table) for the barriers scale in the main survey to assess for internal consistency/reliability. The Cronbach's alpha for the scale was .916, greater than the recommended minimum level of .7 (Pallant, 2016, p. 6).

Table 4.12

\section{Barriers}

\begin{tabular}{|c|c|c|c|c|c|c|}
\hline & $\begin{array}{c}\text { Total } \\
\text { RDNs } \\
\text { N = 1043 } \\
\text { Mean (SD) }\end{array}$ & $\begin{array}{c}\text { Current } \\
\text { Preceptors } \\
n=408 \\
\text { mean (SD) }\end{array}$ & $\begin{array}{c}\text { Former } \\
\text { Preceptors } \\
\text { n= } 359 \\
\text { mean (SD) }\end{array}$ & $\begin{array}{c}\text { Never } \\
\text { Precepted } \\
\text { n= 273 } \\
\text { mean (SD) }\end{array}$ & $\mathbf{F}$ & $\mathbf{p}$ \\
\hline Barriers overall & $\begin{array}{l}2.08 \\
(.81)\end{array}$ & $\begin{array}{l}1.92^{\mathrm{a}} \\
(.76)\end{array}$ & $\begin{array}{l}1.95^{\mathrm{a}} \\
(.79)\end{array}$ & $\begin{array}{c}2.49^{\mathrm{b}}( \\
.78)\end{array}$ & 47.873 & $.000 *$ \\
\hline $\begin{array}{l}\text { Increased stress from } \\
\text { having interns }\end{array}$ & $\begin{array}{c}3.10 \\
(1.28) \\
\end{array}$ & $\begin{array}{l}3.30^{\mathrm{a}} \\
(1.17) \\
\end{array}$ & $\begin{array}{l}2.77^{\mathrm{b}} \\
(1.40) \\
\end{array}$ & $\begin{array}{r}3.22^{\mathrm{a}} \\
(1.20) \\
\end{array}$ & 16.975 & $.000 *$ \\
\hline $\begin{array}{l}\text { Time-consuming/ } \\
\text { increased workload }\end{array}$ & $\begin{array}{c}3.04 \\
(1.48) \\
\end{array}$ & $\begin{array}{l}3.16^{\mathrm{a}} \\
(1.42) \\
\end{array}$ & $\begin{array}{l}2.75^{\mathrm{b}} \\
(1.58) \\
\end{array}$ & $\begin{array}{l}3.23^{\mathrm{a}} \\
(1.37) \\
\end{array}$ & 9.960 & $.000 *$ \\
\hline $\begin{array}{l}\text { Lack of incentives (i.e., } \\
\text { financial compensation) }\end{array}$ & $\begin{array}{c}2.77 \\
(1.54) \\
\end{array}$ & $\begin{array}{l}2.73^{\mathrm{a}} \\
(1.57) \\
\end{array}$ & $\begin{array}{l}2.61^{\mathrm{a}} \\
(1.60) \\
\end{array}$ & $\begin{array}{l}3.06^{\mathrm{b}} \\
(1.35) \\
\end{array}$ & 8.149 & $.000^{*}$ \\
\hline Lack of preceptor training & $\begin{array}{c}2.38 \\
(1.38)\end{array}$ & $\begin{array}{l}2.14^{\mathrm{a}} \\
(1.31)\end{array}$ & $\begin{array}{l}2.20^{\mathrm{a}} \\
(1.43)\end{array}$ & $\begin{array}{l}2.97^{\mathrm{b}} \\
(1.24)\end{array}$ & 41.637 & $.000 *$ \\
\hline
\end{tabular}




\begin{tabular}{|c|c|c|c|c|c|c|}
\hline & $\begin{array}{c}\text { Total } \\
\text { RDNs } \\
\mathrm{N}=\mathbf{1 0 4 3} \\
\text { Mean (SD) }\end{array}$ & $\begin{array}{c}\text { Current } \\
\text { Preceptors } \\
n=408 \\
\text { mean (SD) }\end{array}$ & $\begin{array}{c}\text { Former } \\
\text { Preceptors } \\
\mathbf{n}=359 \\
\text { mean (SD) }\end{array}$ & $\begin{array}{c}\text { Never } \\
\text { Precepted } \\
n=273 \\
\text { mean (SD) }\end{array}$ & $\mathbf{F}$ & $\mathbf{p}$ \\
\hline Lack of preceptor support & $\begin{array}{c}2.31 \\
(1.35) \\
\end{array}$ & $\begin{array}{l}2.11^{\mathrm{a}} \\
(1.32) \\
\end{array}$ & $\begin{array}{r}2.22^{\mathrm{a}} \\
(1.42) \\
\end{array}$ & $\begin{array}{r}2.74^{\mathrm{b}} \\
(1.19) \\
\end{array}$ & 23.223 & $.000 *$ \\
\hline Short-staffed or downsizing & $\begin{array}{c}2.31 \\
(1.54)\end{array}$ & $\begin{array}{c}2.31 \\
(1.55)\end{array}$ & $\begin{array}{c}2.23 \\
(1.60)\end{array}$ & $\begin{array}{c}2.40 \\
(1.43)\end{array}$ & .951 & .387 \\
\hline $\begin{array}{l}\text { Lack of appreciation/ } \\
\text { recognition }\end{array}$ & $\begin{array}{c}2.24 \\
(1.39)\end{array}$ & $\begin{array}{c}2.25 \\
(1.40)\end{array}$ & $\begin{array}{c}2.12 \\
(1.44)\end{array}$ & $\begin{array}{c}2.37 \\
(1.29)\end{array}$ & 2.763 & .064 \\
\hline Workspace limitations & $\begin{array}{c}2.24 \\
(1.52) \\
\end{array}$ & $\begin{array}{l}2.04^{\mathrm{a}} \\
(1.49)\end{array}$ & $\begin{array}{l}2.06^{\mathrm{a}} \\
(1.58) \\
\end{array}$ & $\begin{array}{l}2.77^{\mathrm{b}} \\
(1.37) \\
\end{array}$ & 26.722 & $.000^{*}$ \\
\hline Length of rotation & $\begin{array}{c}2.22 \\
(1.29)\end{array}$ & $\begin{array}{l}2.15^{\mathrm{a}} \\
(1.36)\end{array}$ & $\begin{array}{l}2.01^{\mathrm{a}} \\
(1.25)\end{array}$ & $\begin{array}{l}2.61^{\mathrm{b}} \\
(1.16)\end{array}$ & 21.667 & $.000 *$ \\
\hline $\begin{array}{l}\text { Legal issues (i.e., internship } \\
\text { contracts or agreements) }\end{array}$ & $\begin{array}{c}2.13 \\
(1.42) \\
\end{array}$ & $\begin{array}{l}1.71^{\mathrm{a}} \\
(1.34) \\
\end{array}$ & $\begin{array}{l}2.17^{\mathrm{b}} \\
(1.47) \\
\end{array}$ & $\begin{array}{l}2.71^{\mathrm{c}} \\
(1.26) \\
\end{array}$ & 48.799 & $.000^{*}$ \\
\hline $\begin{array}{l}\text { Liability/regulatory } \\
\text { concerns }\end{array}$ & $\begin{array}{c}2.10 \\
(1.33)\end{array}$ & $\begin{array}{l}1.72^{\mathrm{a}} \\
(1.23)\end{array}$ & $\begin{array}{l}2.03^{\mathrm{b}} \\
(1.35)\end{array}$ & $\begin{array}{l}2.73^{\mathrm{c}} \\
(1.22) \\
\end{array}$ & 57.680 & $.000^{*}$ \\
\hline $\begin{array}{l}\text { Length of intern onboarding } \\
\text { process }\end{array}$ & $\begin{array}{c}2.00 \\
(1.29) \\
\end{array}$ & $\begin{array}{l}1.70^{\mathrm{a}} \\
(1.23) \\
\end{array}$ & $\begin{array}{l}1.92^{\mathrm{b}} \\
(1.30)\end{array}$ & $\begin{array}{l}2.53^{\mathrm{c}} \\
(1.19) \\
\end{array}$ & 40.649 & $.000 *$ \\
\hline Quality of the intern & $\begin{array}{c}1.97 \\
(1.34) \\
\end{array}$ & $\begin{array}{l}2.05^{\mathrm{a}} \\
(1.38) \\
\end{array}$ & $\begin{array}{l}1.77^{\mathrm{b}} \\
(1.32)\end{array}$ & $\begin{array}{l}2.11^{\mathrm{a}} \\
(1.29) \\
\end{array}$ & 6.353 & $.002 *$ \\
\hline $\begin{array}{l}\text { Unable to demonstrate } \\
\text { added value of having } \\
\text { interns }\end{array}$ & $\begin{array}{c}1.92 \\
(1.37)\end{array}$ & $\begin{array}{r}1.73^{\mathrm{a}} \\
(1.37)\end{array}$ & $\begin{array}{r}1.82^{\mathrm{a}} \\
(1.34)\end{array}$ & $\begin{array}{l}2.33^{\mathrm{b}} \\
(1.34)\end{array}$ & 17.467 & $.000 *$ \\
\hline $\begin{array}{l}\text { Restricted by the facility or } \\
\text { management }\end{array}$ & $\begin{array}{c}1.87 \\
(1.49) \\
\end{array}$ & $\begin{array}{c}1.45^{\mathrm{a}} \\
(1.28) \\
\end{array}$ & $\begin{array}{l}1.91^{\mathrm{b}} \\
(1.54) \\
\end{array}$ & $\begin{array}{l}2.44^{\mathrm{c}} \\
(1.52) \\
\end{array}$ & 40.220 & $.000 *$ \\
\hline $\begin{array}{l}\text { Quality of the internship } \\
\text { program }\end{array}$ & $\begin{array}{c}1.83 \\
(1.31) \\
\end{array}$ & $\begin{array}{r}1.80^{\mathrm{a}} \\
(1.32) \\
\end{array}$ & $\begin{array}{l}1.67^{\mathrm{a}} \\
(1.30)\end{array}$ & $\begin{array}{l}2.09^{\mathrm{b}} \\
(1.26) \\
\end{array}$ & 8.780 & $.000^{*}$ \\
\hline $\begin{array}{l}\text { My health and/or family } \\
\text { personal obligations }\end{array}$ & $\begin{array}{c}1.82 \\
(1.41)\end{array}$ & $\begin{array}{l}1.63^{\mathrm{a}} \\
(1.30)\end{array}$ & $\begin{array}{l}1.52^{\mathrm{a}} \\
(1.33)\end{array}$ & $\begin{array}{l}2.47^{\mathrm{b}} \\
(1.47)\end{array}$ & 40.400 & $.000^{*}$ \\
\hline $\begin{array}{l}\text { Not enough for interns to do } \\
\text { at my workplace }\end{array}$ & $\begin{array}{c}1.77 \\
(1.44) \\
\end{array}$ & $\begin{array}{r}1.38^{\mathrm{a}} \\
(1.27) \\
\end{array}$ & $\begin{array}{l}1.67^{\mathrm{b}} \\
(1.46) \\
\end{array}$ & $\begin{array}{l}2.47^{\mathrm{c}} \\
(1.42) \\
\end{array}$ & 53.230 & $.000^{*}$ \\
\hline Lack of personal motivation & $\begin{array}{c}1.74 \\
(1.27)\end{array}$ & $\begin{array}{l}1.63^{\mathrm{a}} \\
(1.23)\end{array}$ & $\begin{array}{l}1.62^{\mathrm{a}} \\
(1.28)\end{array}$ & $\begin{array}{l}2.07^{\mathrm{b}} \\
(1.27)\end{array}$ & 13.033 & $.000^{*}$ \\
\hline $\begin{array}{l}\text { Technology or electronic } \\
\text { medical record issues }\end{array}$ & $\begin{array}{c}1.62 \\
(1.28)\end{array}$ & $\begin{array}{l}1.51^{\mathrm{a}} \\
(1.27)\end{array}$ & $\begin{array}{l}1.50^{\mathrm{a}} \\
(1.27)\end{array}$ & $\begin{array}{l}1.95^{\mathrm{b}} \\
(1.27)\end{array}$ & 12.118 & $.000^{*}$ \\
\hline $\begin{array}{l}\text { Unfamiliar with an } \\
\text { internship program }\end{array}$ & $\begin{array}{c}1.59 \\
(1.35) \\
\end{array}$ & $\begin{array}{l}1.13^{\mathrm{a}} \\
(1.06) \\
\end{array}$ & $\begin{array}{l}1.27^{\mathrm{a}} \\
(1.11) \\
\end{array}$ & $\begin{array}{l}2.69^{\mathrm{b}} \\
(1.41) \\
\end{array}$ & 131.44 & $.000 *$ \\
\hline $\begin{array}{l}\text { Negative experience with } \\
\text { internship program/prior } \\
\text { intern }\end{array}$ & $\begin{array}{c}1.44 \\
(1.25)\end{array}$ & $\begin{array}{c}1.53 \\
(1.29)\end{array}$ & $\begin{array}{c}1.33 \\
(1.23)\end{array}$ & $\begin{array}{c}1.47 \\
(1.20)\end{array}$ & 2.591 & .076 \\
\hline $\begin{array}{l}\text { State licensure/certification } \\
\text { regulations }\end{array}$ & $\begin{array}{c}1.34 \\
(1.09)\end{array}$ & $\begin{array}{l}1.12^{\mathrm{a}} \\
(.97) \\
\end{array}$ & $\begin{array}{r}1.18^{\mathrm{a}} \\
(1.00)\end{array}$ & $\begin{array}{l}1.19^{\mathrm{b}} \\
(1.86)\end{array}$ & 39.363 & $.000 *$ \\
\hline
\end{tabular}

Ns vary slightly secondary to missing data.

Scale: 0 = Strongly Disagree), $1=$ Disagree, $2=$ Somewhat Disagree, $3=$ Somewhat Agree, $4=$ Agree, $5=$ Strongly Agree). Lower score $=$ fewer barriers, .

Homogeneity of variances was violated, Levene test significant. Used Welch F test and Games Howell post-hoc analysis to correct for multiple tests. $* \mathrm{p}<0.05$. P values are for overall difference across the tables.

Means $>2.5$ highlighted in each column

Means with differing superscripts $(a, b, c)$ within the same row are significantly different at the $p<.05$ level based on post-hoc test. 
Table 4.13 indicates the top reasons former preceptors stopped precepting were secondary to changing jobs/positions, resigned, retired (19.9\%), workload or short-staffed (5.7\%), no contract or contract issues with the internship (3.2\%), workspace limitations $(2.8 \%)$, and a change in management $(1.8 \%)$.

Table 4.13

Reasons Former Preceptors Stopped Precepting

\begin{tabular}{lc}
\cline { 2 - 2 } & $\begin{array}{c}\text { Former } \\
\text { Preceptors } \\
\mathbf{\%}(\mathbf{n})\end{array}$ \\
\hline Changed jobs/positions, resigned, retired & $19.9(233)$ \\
\hline Workload or short staffed & $5.7(67)$ \\
\hline No contract or contract issues with the internship & $3.2(37)$ \\
\hline Workspace limitations & $2.8(33)$ \\
\hline Change in management & $1.8(21)$ \\
\hline Not working or on leave of absence & $1.7(20)$ \\
\hline Unable to demonstrate added value of precepting interns & $1.4(16)$ \\
\hline Stress or personal circumstances & $1.2(14)$ \\
\hline Too much paperwork & $0.9(10)$ \\
\hline Instructed by Director/Manager/Supervisor/Coordinator & $0.7(8)$ \\
\hline Company lost account or merger & $0.5(6)$ \\
\hline Technology of electronic medical record related & $0.3(4)$ \\
\hline Instructed by Human Resources & $0.3(3)$ \\
\hline Instructed by Owner, CEO, or Senior Staff/Administration & $0.3(3)$ \\
\hline Other & $5.1(60)$ \\
\hline
\end{tabular}

An independent-samples t-test was also conducted (see Table 4.14) to compare former and never precepted responses to the following statements: "I would be an effective preceptor," "I am confident I have the knowledge and skills to precept," and "I would need training before precepting a dietetic intern." There was a significant difference found between the two group means for all three items, with former preceptors responding higher than those who have never precepted. There was a meaningful difference of $.5 \mathrm{SD}$ between the two groups regarding their confidence in having the 
knowledge and skills to precept; and the biggest meaningful difference in the table, of

$>1 \mathrm{SD}$, was found between former and never precepted groups for the statement "I

would need training before precepting..."

Table 4.14

Being an Effective Preceptor, Confidence in Knowledge and Skills, Need for Training

\begin{tabular}{|c|c|c|c|c|c|c|}
\hline & $\begin{array}{c}\text { Total } \\
\text { N }=638 \\
\text { Mean (SD) }\end{array}$ & $\begin{array}{c}\text { Current } \\
\text { Preceptors } \\
\text { n = NA } \\
\text { mean (SD) }\end{array}$ & $\begin{array}{c}\text { Former } \\
\text { Preceptors } \\
\text { n = } \mathbf{3 6 1} \\
\text { mean (SD) }\end{array}$ & $\begin{array}{c}\text { Never } \\
\text { Precepted } \\
\text { n = 277 } \\
\text { mean (SD) }\end{array}$ & $\mathbf{t}$ & $\mathbf{p}$ \\
\hline $\begin{array}{l}\text { I would be an } \\
\text { effective preceptor. } \\
\text { mean (SD) }\end{array}$ & $\begin{array}{l}3.91 \\
(.90)\end{array}$ & NA & $\begin{array}{l}4.06^{\mathrm{a}} \\
(.85)\end{array}$ & $\begin{array}{l}3.72^{\mathrm{b}} \\
(.92)\end{array}$ & -4.776 & $.000^{*}$ \\
\hline $\begin{array}{l}\text { I am confident I have } \\
\text { the knowledge and } \\
\text { skills to precept. } \\
\text { mean (SD) }\end{array}$ & $\begin{array}{l}3.84 \\
(.92)\end{array}$ & NA & $\begin{array}{l}4.04^{\mathrm{a}} \\
(.84)\end{array}$ & $\begin{array}{l}3.58^{\mathrm{b}} \\
(.95)\end{array}$ & -6.429 & $.000 *$ \\
\hline $\begin{array}{l}\text { I would need training } \\
\text { before precepting a } \\
\text { dietetic intern. mean }{ }^{\infty} \\
\text { (SD) }\end{array}$ & $\begin{array}{l}2.21 \\
(1.44)\end{array}$ & NA & $\begin{array}{l}2.80^{\mathrm{a}} \\
(1.32)\end{array}$ & $\begin{array}{c}1.46^{\mathrm{b}} \\
(1.24)\end{array}$ & -13.272 & $.000 *$ \\
\hline
\end{tabular}

Ns vary based on missing data.

Independent-samples t-test, equal variances not assumed.

Scale: $0=$ strongly disagree to $5=$ strongly agree,

${ }^{\infty}$ Scale: $0=$ strongly agree to $5=$ strongly disagree.

Means with differing superscripts $(\mathrm{a}, \mathrm{b}, \mathrm{c})$ within the same row are significantly different at the $\mathrm{p}<.05$ level based on post hoc test.

$\mathrm{NA}=$ not asked

\section{Research Question 3}

What are the RDs perceived benefits, support, satisfaction, and commitment to the preceptor role?

Cronbach's alpha was conducted (not shown in table) for each scale in the main survey to assess for internal consistency/reliability. The Cronbach's alpha for the scales were all greater than the recommended minimum level of .7 (Pallant, 2016, p. 6). The benefits scale was $.903(\mathrm{~N}=1150)$, commitment $.889(\mathrm{~N}=1115)$, support $.901(\mathrm{~N}=$ 1073), and satisfaction $.865(\mathrm{~N}=1026)$. 
Total mean scores for the perceived benefits was the highest 3.84 ( agree), with similar means found in each of the groups. Total commitment mean score was 3.79 , total satisfaction mean score was 3.42, and support scored the lowest of the four scales with a mean of 3.05 (somewhat agree). Current and former preceptors also scored significantly higher than never precepted respondents on the these three scales: commitment $(C=3.91$, $\mathrm{F}=3.92, \mathrm{~N}=3.48)$, satisfaction $(\mathrm{C}=3.48, \mathrm{~F}=3.49, \mathrm{~N}=3.24)$, and support $(\mathrm{C}=3.18$, $\mathrm{F}=3.06, \mathrm{~N}=2.85)$. The biggest meaningful difference between the group means for the scales was between current and never on the commitment to the preceptor role scale, with a difference of $>.5 \mathrm{SD}$.

Table 4.15

Preceptor's Perceptions of Benefits and Rewards, Commitment to the Preceptor Role, Satisfaction and Preceptor's Perception of Support Scale Scores - by Preceptor Status

\begin{tabular}{|c|c|c|c|c|c|c|}
\hline Scale & $\begin{array}{c}\text { Total } \\
\text { RDNs } \\
\mathrm{N}=993 \\
\text { Mean (SD) }\end{array}$ & $\begin{array}{c}\text { Current } \\
\text { Preceptors } \\
\text { n = 394 } \\
\text { mean (SD) }\end{array}$ & $\begin{array}{c}\text { Former } \\
\text { Preceptors } \\
\text { n = } 341 \\
\text { mean (SD) }\end{array}$ & $\begin{array}{c}\text { Never } \\
\text { Precepted } \\
\text { n = 258 } \\
\text { mean (SD) }\end{array}$ & $\mathbf{F}$ & $\mathbf{p}$ \\
\hline $\begin{array}{l}\text { Preceptor's Perceptions } \\
\text { of Benefits and } \\
\text { Rewards (PPBR) }\end{array}$ & $\begin{array}{l}3.84 \\
(.85)\end{array}$ & $\begin{array}{l}3.87 \\
(.84)\end{array}$ & $\begin{array}{l}3.76 \\
(.91)\end{array}$ & $\begin{array}{l}3.88 \\
(.77)\end{array}$ & 2.176 & .114 \\
\hline $\begin{array}{l}\text { Commitment to } \\
\text { Preceptor Role (CPR) }\end{array}$ & $\begin{array}{l}3.79 \\
(.77)\end{array}$ & $\begin{array}{l}3.91^{\mathrm{a}} \\
(.74)\end{array}$ & $\begin{array}{l}3.92^{\mathrm{a}} \\
(.73)\end{array}$ & $\begin{array}{l}3.48^{\mathrm{b}} \\
(.78)\end{array}$ & 36.339 & $.000 *$ \\
\hline Satisfaction & $\begin{array}{l}3.42 \\
(.81) \\
\end{array}$ & $\begin{array}{l}3.48^{\mathrm{a}} \\
(.79)\end{array}$ & $\begin{array}{l}3.49^{\mathrm{a}} \\
(.83)\end{array}$ & $\begin{array}{l}3.24^{\mathrm{b}} \\
(.78)\end{array}$ & 9.553 & $.000 *$ \\
\hline $\begin{array}{l}\text { Preceptor's Perception } \\
\text { of Support (PPS) }\end{array}$ & $\begin{array}{l}3.05 \\
(.89)\end{array}$ & $\begin{array}{l}3.18^{\mathrm{a}} \\
(.95)\end{array}$ & $\begin{array}{l}3.06^{\mathrm{a}} \\
(.86)\end{array}$ & $\begin{array}{l}2.85^{\mathrm{b}} \\
(.80)\end{array}$ & 12.470 & $.000 *$ \\
\hline
\end{tabular}

Ns vary based on missing data.

Scale $0=$ Strongly Disagree, $1=$ Disagree, $2=$ Somewhat Disagree, $3=$ Somewhat Agree, $4=$ Agree, $5=$ Strongly Agree.

Homogeneity of variances was violated, Levene test significant. Used Welch's ANOVA test and Games Howell posthoc analysis to correct for multiple tests. Means with differing superscripts (a, b, c) within the same row are significantly different at the $\mathrm{p}<.05$ level based on post hoc test.

$* \mathrm{p}<0.05$. P values are for overall difference across the tables. PPBR, CPR, PPS adapted from nursing literature (Dibert \& Goldenberg, 1995); Satisfaction scale adapted/modified from the satisfaction subscale of the Clinical Preceptor Experience Evaluation Tool (CPEET) (O’Brien et al., 2014); Barrier scale was created based on literature review, RDN feedback, pilot, etc. 
The analysis of the means of the nine items included in the commitment to the preceptor role scale are in Table 4.15a. The top means overall included (1) "I care about the fate of the preceptors conducting supervised practice in dietetics" (mean $=4.06$ agree), (2) "deciding to be a preceptor was/would be a mistake on my part" (mean = 4.05 disagree; differences > .5 SD between current and never, and former and never), (3) "being a preceptor inspires me/would inspire me to perform my best" (mean $=4.01$ agree), and (4) my philosophy of practice and the expectations of the preceptor role are aligned" (mean $=3.95 \sim$ agree). Statistically significant differences among the three groups were found for all nine of the statements in the scale, with the biggest difference and lowest scores seen in the never group of RDN respondents.

The second to lowest scored statement was related to being enthusiastic about the preceptor role when talking to colleagues $($ mean $=3.42)$ and there were significant differences between current and never as well as former and never, > .5 SD (means: $\mathrm{C}=$ 3.61, $\mathrm{F}=3.65, \mathrm{~N}=2.89$ ). The lowest scored statement on the scale overall was "I feel a sense of loyalty to the preceptor role" (mean $=3.42$ ), with all three groups responding significantly different from the other and never responding the lowest, somewhat agreeing with the statement (means: $\mathrm{C}=3.72, \mathrm{~F}=3.51, \mathrm{~N}=2.92$ ). The difference between the current and never respondents for this loyalty statement was meaningful, with a difference of $>1 \mathrm{SD}$. 
Table 4.15a

Commitment to Preceptor Role

\begin{tabular}{|c|c|c|c|c|c|c|}
\hline & $\begin{array}{c}\text { Total } \\
\text { RDNs } \\
\text { N }=1131 \\
\text { mean } \\
\end{array}$ & $\begin{array}{c}\text { Current } \\
\text { Preceptors } \\
\text { n }=427 \\
\text { mean } \\
\end{array}$ & $\begin{array}{c}\text { Former } \\
\text { Preceptors } \\
\text { n = } \mathbf{3 8 6} \\
\text { mean } \\
\end{array}$ & $\begin{array}{c}\text { Never } \\
\text { Precepted } \\
\text { n = 315 } \\
\text { mean } \\
\end{array}$ & $\mathbf{F}$ & $\mathbf{p}$ \\
\hline \multicolumn{7}{|l|}{ Commitment questions } \\
\hline $\begin{array}{l}\text { I care about the fate of } \\
\text { preceptors conducting } \\
\text { supervised practice in dietetics }\end{array}$ & $\begin{array}{l}4.06 \\
(.88)\end{array}$ & $\begin{array}{l}4.14^{\mathrm{a}} \\
(.85)\end{array}$ & $\begin{array}{l}4.13^{\mathrm{a}} \\
(.88)\end{array}$ & $\begin{array}{l}3.88^{\mathrm{b}} \\
(.90)\end{array}$ & 9.419 & $.000 *$ \\
\hline $\begin{array}{l}\text { Deciding to be a preceptor } \\
\text { was/would be a mistake on my } \\
\text { part }^{+}, \infty\end{array}$ & $\begin{array}{c}4.05 \\
(1.12)\end{array}$ & $\begin{array}{l}4.29^{\mathrm{a}} \\
(1.00)\end{array}$ & $\begin{array}{l}4.27^{\mathrm{a}} \\
(.99)\end{array}$ & $\begin{array}{l}3.48^{\mathrm{b}} \\
(1.22)\end{array}$ & 55.696 & $.000 *$ \\
\hline $\begin{array}{l}\text { Being a preceptor inspires } \\
\text { me/would inspire me to } \\
\text { perform my best }^{+}\end{array}$ & $\begin{array}{l}4.01 \\
(.96)\end{array}$ & $\begin{array}{l}4.05^{\mathrm{a}} \\
(1.00)\end{array}$ & $\begin{array}{l}4.12^{\mathrm{a}} \\
(.89)\end{array}$ & $\begin{array}{l}3.85^{\mathrm{b}} \\
(.98)\end{array}$ & 7.466 & $.001 *$ \\
\hline $\begin{array}{l}\text { My philosophy of practice and } \\
\text { the expectations of the } \\
\text { preceptor role are aligned }\end{array}$ & $\begin{array}{l}3.95 \\
(.88)\end{array}$ & $\begin{array}{l}4.02^{\mathrm{a}} \\
(.86)\end{array}$ & $\begin{array}{l}4.03^{\mathrm{a}} \\
(.85)\end{array}$ & $\begin{array}{l}3.78^{\mathrm{b}} \\
(.92)\end{array}$ & 8.091 & $.000 *$ \\
\hline $\begin{array}{l}\text { I am/would be proud to tell } \\
\text { others that I am/was a } \\
\text { preceptor }^{+}\end{array}$ & $\begin{array}{c}3.83 \\
(1.07)\end{array}$ & $\begin{array}{l}3.85^{\mathrm{ab}} \\
(1.08)\end{array}$ & $\begin{array}{l}3.93^{\mathrm{b}} \\
(1.06)\end{array}$ & $\begin{array}{r}3.68^{\mathrm{a}} \\
(1.06)\end{array}$ & 5.226 & $.006^{*}$ \\
\hline $\begin{array}{l}\text { There is not much to be } \\
\text { gained by acting as a } \\
\text { preceptor }{ }^{\infty}\end{array}$ & $\begin{array}{c}3.73 \\
(1.17)\end{array}$ & $\begin{array}{c}3.79^{\mathrm{a}} \\
(1.18)\end{array}$ & $\begin{array}{l}3.85^{\mathrm{a}} \\
(1.18)\end{array}$ & $\begin{array}{c}3.49^{\mathrm{b}} \\
(1.10)\end{array}$ & 10.348 & $.000 *$ \\
\hline $\begin{array}{l}\text { I am/would be willing to put } \\
\text { in a great deal of effort } \\
\text { beyond what is normally } \\
\text { expected in order to help the } \\
\text { intern be successful }^{+}\end{array}$ & $\begin{array}{c}3.63 \\
(1.05)\end{array}$ & $\begin{array}{l}3.73^{\mathrm{a}} \\
(.98)\end{array}$ & $\begin{array}{l}3.77^{\mathrm{a}} \\
(.98)\end{array}$ & $\begin{array}{r}3.33^{\mathrm{b}} \\
(1.15)\end{array}$ & 17.096 & $.000 *$ \\
\hline $\begin{array}{l}\text { I am enthusiastic about the } \\
\text { preceptor role when I talk to } \\
\text { my colleagues }\end{array}$ & $\begin{array}{c}3.42 \\
(1.17)\end{array}$ & $\begin{array}{r}3.61^{\mathrm{a}} \\
(1.08)\end{array}$ & $\begin{array}{l}3.65^{\mathrm{a}} \\
(1.12)\end{array}$ & $\begin{array}{l}2.89^{b} \\
(1.18)\end{array}$ & 45.879 & $.000 *$ \\
\hline $\begin{array}{l}\text { I feel a sense of loyalty to the } \\
\text { preceptor role }\end{array}$ & $\begin{array}{c}3.42 \\
(1.22)\end{array}$ & $\begin{array}{c}3.72^{\mathrm{a}} \\
(1.08)\end{array}$ & $\begin{array}{c}3.51^{\mathrm{b}} \\
(1.18)\end{array}$ & $\begin{array}{c}2.92^{\mathrm{c}} \\
(1.27)\end{array}$ & 41.348 & $.000 *$ \\
\hline
\end{tabular}

Ns vary based on missing data. +Statement wording differs slightly according to status, refer to Main Survey in Appendix L.

Scale $0=$ strongly disagree to $5=$ strongly agree;

${ }^{\infty}$ Scale $0=$ strongly agree to $5=$ strongly disagree

Means with differing superscripts $(\mathrm{a}, \mathrm{b}, \mathrm{c})$ within the same row are significantly different at the $\mathrm{p}<.05$ level based on post hoc test.

Homogeneity of variances was violated, Levene test significant. Used Welch F test and Games Howell post-hoc analysis to correct for multiple tests. ${ }^{*} \mathrm{p}<0.05$. $\mathrm{P}$ values are for overall difference across the tables.

The analysis of the means of the six items included in the satisfaction scale related

to the preceptor role is in Table 4.15b. The top means overall included: (1) "it is

stimulating to work with enthusiastic interns" (mean $=4.0 \sim$ agree), (2) "I enjoy the

intern/preceptor interaction" (mean $=3.76 \sim$ agree), and (3) "the role of preceptor is 
professionally rewarding" (mean $=3.62 \sim$ somewhat agree to agree). Statistically significant differences among the three groups were found for all six of the statements in the scale, with the biggest difference and lowest scores seen throughout most of the items in the never group of RDN respondents.

On the bottom of the list of satisfaction mean scores by item was "I am satisfied with the incentives offered/received for precepting," with RDNs somewhat disagreeing with the statement $($ mean $=1.98)$, which was also in Table 4.7, discussed under Research Question 1 related to incentives. The second lowest score in the items in the satisfaction table was under the never group with a mean of 3.30, somewhat agreeing that "being a preceptor is satisfying."

Table $4.15 b$

Satisfaction Related to Precepting

\begin{tabular}{|c|c|c|c|c|c|c|}
\hline & $\begin{array}{c}\text { Total } \\
\text { RDNs } \\
\text { N = 1034 } \\
\text { Mean } \\
\text { (SD) }\end{array}$ & $\begin{array}{c}\text { Current } \\
\text { Preceptors } \\
\mathbf{n}=\mathbf{4 1 0} \\
\text { mean } \\
\text { (SD) } \\
\end{array}$ & $\begin{array}{c}\text { Former } \\
\text { Preceptors } \\
\mathbf{n}=359 \\
\text { mean } \\
(\text { SD) } \\
\end{array}$ & $\begin{array}{c}\text { Never } \\
\text { Precepted } \\
\mathbf{n}=\mathbf{2 6 5} \\
\text { mean } \\
(\text { SD) } \\
\end{array}$ & $\mathbf{F}$ & $\mathbf{p}$ \\
\hline \multicolumn{7}{|l|}{ Satisfaction questions } \\
\hline $\begin{array}{l}\text { It is stimulating to work with } \\
\text { enthusiastic interns }\end{array}$ & $\begin{array}{c}4.0 \\
(.876)\end{array}$ & $\begin{array}{l}4.12^{\mathrm{a}} \\
(.84)\end{array}$ & $\begin{array}{l}4.07^{\mathrm{a}} \\
(.85)\end{array}$ & $\begin{array}{l}3.71^{\mathrm{b}} \\
(.90)\end{array}$ & 19.219 & $.000 *$ \\
\hline $\begin{array}{l}\text { I enjoy the intern/preceptor } \\
\text { interaction }\end{array}$ & $\begin{array}{l}3.76 \\
(.91)\end{array}$ & $\begin{array}{l}3.87^{\mathrm{a}} \\
(.88)\end{array}$ & $\begin{array}{l}3.88^{\mathrm{a}} \\
(.88)\end{array}$ & $\begin{array}{l}3.43^{\mathrm{b}} \\
(.93)\end{array}$ & 23.057 & $.000 *$ \\
\hline $\begin{array}{l}\text { The role of preceptor is } \\
\text { professionally rewarding }\end{array}$ & $\begin{array}{c}3.62 \\
(1.00)\end{array}$ & $\begin{array}{l}3.68^{\mathrm{a}} \\
(.99)\end{array}$ & $\begin{array}{l}3.71^{\mathrm{a}} \\
(1.06) \\
\end{array}$ & $\begin{array}{l}3.42^{\mathrm{b}} \\
(.91)\end{array}$ & 8.533 & $.000 *$ \\
\hline Being a preceptor is satisfying & $\begin{array}{l}3.61 \\
(.97)\end{array}$ & $\begin{array}{l}3.68^{\mathrm{a}} \\
(.94)\end{array}$ & $\begin{array}{l}3.74^{\mathrm{a}} \\
(1.02) \\
\end{array}$ & $\begin{array}{l}3.30^{\mathrm{b}} \\
(.90)\end{array}$ & 19.500 & $.000 *$ \\
\hline $\begin{array}{l}\text { The preceptor role is an } \\
\text { incentive to teach }\end{array}$ & $\begin{array}{c}3.57 \\
(1.05) \\
\end{array}$ & $\begin{array}{l}3.60^{\mathrm{ab}} \\
(1.07) \\
\end{array}$ & $\begin{array}{l}3.64^{\mathrm{a}} \\
(1.10) \\
\end{array}$ & $\begin{array}{l}3.42^{\mathrm{b}} \\
(.94) \\
\end{array}$ & 4.088 & $.017 *$ \\
\hline $\begin{array}{l}\text { I am satisfied with the } \\
\text { incentives offered/received for } \\
\text { precepting }\end{array}$ & $\begin{array}{c}1.98 \\
(1.36)\end{array}$ & $\begin{array}{r}1.92^{\mathrm{a}} \\
(1.37)\end{array}$ & $\begin{array}{r}1.90^{\mathrm{a}} \\
(1.42)\end{array}$ & $\begin{array}{l}2.19^{\mathrm{b}} \\
(1.23)\end{array}$ & 4.685 & $.010^{*}$ \\
\hline
\end{tabular}


The analysis of the means of the nine items included in the support scale related to the preceptor role is in Table 4.15c. The top means overall included: (1) "co-workers are typically supportive of RDs when they function as a preceptor" (mean $=3.46$ ), and (2) "management/administration are supportive of RDs in the preceptor role" (mean = 3.33). Statistically significant differences among the three groups were found for the top six of the nine statements in the scale, with the biggest differences and lowest in the never group of RDN respondents.

The three most meaningful differences in the items of the support scale, with differences of $>.5 \mathrm{SD}$, were found between the current and never respondents, related to co-workers typically being supportive, management/administration being supportive, and co-workers being supportive when preceptors have to spend extra time with a challenging intern.

The lowest scoring statement on the list of support means was "there are adequate opportunities for preceptors to share information with other preceptors" (mean $=2.53$ $\sim$ somewhat disagree to somewhat agree). The second lowest score in the table was "the workload of an RD is still manageable when functioning as a preceptor" (mean $=2.63$ ), followed by "support is available to help preceptors develop in their role" (mean $=2.89$ $\sim$ somewhat agree) and "preceptors have adequate preparation for their role" (mean $=2.89$ $\sim$ somewhat agree). 
Table 4.15c

Perception of Support

\begin{tabular}{|c|c|c|c|c|c|c|}
\hline & \\
\hline & $\begin{array}{c}\text { Total } \\
\text { RDNs } \\
\text { N = 1095 } \\
\text { Mean } \\
\text { (SD) }\end{array}$ & $\begin{array}{c}\text { Current } \\
\text { Preceptors } \\
\text { n= } 423 \\
\text { mean } \\
\text { (SD) }\end{array}$ & $\begin{array}{c}\text { Former } \\
\text { Preceptors } \\
\text { n }=378 \\
\text { mean } \\
\text { (SD) }\end{array}$ & $\begin{array}{c}\text { Never } \\
\text { Precepted } \\
\text { n = 293 } \\
\text { mean } \\
\text { (SD) }\end{array}$ & $\mathbf{F}$ & $\mathbf{p}$ \\
\hline \multicolumn{7}{|l|}{ Support questions } \\
\hline $\begin{array}{l}\text { Co-workers are typically } \\
\text { supportive of RDs when they } \\
\text { function as a preceptor }\end{array}$ & $\begin{array}{c}3.46 \\
(1.03)\end{array}$ & $\begin{array}{l}3.71^{\mathrm{a}} \\
(1.03)\end{array}$ & $\begin{array}{l}3.42^{\mathrm{b}} \\
(.98)\end{array}$ & $\begin{array}{l}3.14^{\mathrm{c}} \\
(1.01)\end{array}$ & 27.957 & $.000^{*}$ \\
\hline $\begin{array}{l}\text { Management/ } \\
\text { administration are supportive } \\
\text { of RDs in the preceptor role }\end{array}$ & $\begin{array}{c}3.33 \\
(1.19)\end{array}$ & $\begin{array}{l}3.58^{\mathrm{a}} \\
(1.20)\end{array}$ & $\begin{array}{l}3.36^{\mathrm{b}} \\
(1.17)\end{array}$ & $\begin{array}{l}2.92^{\mathrm{c}} \\
(1.09)\end{array}$ & 29.320 & $.000 *$ \\
\hline $\begin{array}{l}\text { The goals as a preceptor are } \\
\text { clearly defined }\end{array}$ & $\begin{array}{c}3.28 \\
(1.14)\end{array}$ & $\begin{array}{l}3.37^{\mathrm{a}} \\
(1.22)\end{array}$ & $\begin{array}{l}3.36^{\mathrm{a}} \\
(1.13)\end{array}$ & $\begin{array}{l}3.03^{\mathrm{b}} \\
(1.02)\end{array}$ & 10.935 & $.000 *$ \\
\hline $\begin{array}{l}\text { I feel I have had adequate } \\
\text { support from the DI } \\
\text { Program(s) }\end{array}$ & $\begin{array}{c}3.26 \\
(1.20)\end{array}$ & $\begin{array}{l}3.37^{\mathrm{a}} \\
(1.26)\end{array}$ & $\begin{array}{l}3.26^{\mathrm{ab}} \\
(1.22)\end{array}$ & $\begin{array}{l}3.12^{\mathrm{b}} \\
(1.07)\end{array}$ & 4.321 & $.014 *$ \\
\hline $\begin{array}{l}\text { Co-workers are supportive } \\
\text { when preceptors have to spend } \\
\text { extra time with a challenging } \\
\text { intern }\end{array}$ & $\begin{array}{c}3.15 \\
(1.14)\end{array}$ & $\begin{array}{l}3.40^{\mathrm{a}} \\
(1.18)\end{array}$ & $\begin{array}{l}3.13^{\mathrm{b}} \\
(1.09)\end{array}$ & $\begin{array}{l}2.80^{\mathrm{c}} \\
(1.05)\end{array}$ & 26.197 & $.000 *$ \\
\hline $\begin{array}{l}\text { Preceptors have adequate } \\
\text { preparation for their role }\end{array}$ & $\begin{array}{c}2.89 \\
(1.18)\end{array}$ & $\begin{array}{l}3.01^{\mathrm{a}} \\
(1.23)\end{array}$ & $\begin{array}{r}2.92^{\mathrm{a}} \\
(1.23)\end{array}$ & $\begin{array}{l}2.66^{\mathrm{b}} \\
(1.01)\end{array}$ & 9.380 & $.000 *$ \\
\hline $\begin{array}{l}\text { Support is available to help } \\
\text { preceptors develop in their } \\
\text { role }\end{array}$ & $\begin{array}{c}2.89 \\
(1.22)\end{array}$ & $\begin{array}{c}2.97 \\
(1.34)\end{array}$ & $\begin{array}{c}2.88 \\
(1.24)\end{array}$ & $\begin{array}{c}2.79 \\
(1.01)\end{array}$ & 2.029 & .132 \\
\hline $\begin{array}{l}\text { The workload of an RD is still } \\
\text { manageable when functioning } \\
\text { as a preceptor }\end{array}$ & $\begin{array}{c}2.63 \\
(1.31)\end{array}$ & $\begin{array}{c}2.69 \\
(1.34)\end{array}$ & $\begin{array}{c}2.65 \\
(1.37)\end{array}$ & $\begin{array}{c}2.53 \\
(1.21)\end{array}$ & 1.410 & .245 \\
\hline $\begin{array}{l}\text { There are adequate } \\
\text { opportunities for preceptors to } \\
\text { share information with other } \\
\text { preceptors }\end{array}$ & $\begin{array}{c}2.53 \\
(1.26)\end{array}$ & $\begin{array}{c}2.52 \\
(1.36)\end{array}$ & $\begin{array}{c}2.50 \\
(1.29)\end{array}$ & $\begin{array}{c}2.59 \\
(1.08)\end{array}$ & .579 & .561 \\
\hline \multicolumn{7}{|c|}{$\begin{array}{l}\text { Ns vary based on missing data. } \\
\text { Scale } 0=\text { strongly disagree to } 5=\text { strongly agree; } \\
\text { Homogeneity of variances was violated, Levene test significant. Used Welch } \mathrm{F} \text { test and Games Howell post-hoc } \\
\text { analysis to correct for multiple tests. } * \mathrm{p}<0.05 . \mathrm{P} \text { values are for overall difference across the tables. } \\
\text { Means with differing superscripts }(\mathrm{a}, \mathrm{b}, \mathrm{c}) \text { within the same row are significantly different at the } \mathrm{p}<.05 \text { level based on } \\
\text { post-hoc test. }\end{array}$} \\
\hline
\end{tabular}

When comparing the differences in the scale means for RDN responses to the question, if it was solely their decision, would they continue taking interns?, those who reported yes responded significantly higher than RDNs who responded no on the 
benefits, commitment, satisfaction, and support scales. In addition, those who responded no responded significantly higher on the barriers scale than those who responded yes.

Table $4.15 \mathrm{~d}$

Preceptor's Perceptions of Benefits and Rewards, Commitment to the Preceptor Role, Satisfaction, and Preceptor's Perception of Support Scale Scores

If it was solely the RDNs decision would they continue taking interns?

\begin{tabular}{lccccc}
\cline { 2 - 5 } \multicolumn{1}{c}{ Scale } & $\begin{array}{c}\text { Total } \\
\text { RDNs } \\
\mathbf{N}=\mathbf{9 5 5} \\
\text { Mean (SD) }\end{array}$ & $\begin{array}{c}\text { Yes } \\
\mathbf{n = 7 3 2} \\
\text { mean (SD) }\end{array}$ & $\begin{array}{c}\text { No } \\
\mathbf{n = 2 2 3} \\
\text { mean (SD) }\end{array}$ & t & p \\
\hline $\begin{array}{l}\text { Preceptor's Perceptions } \\
\text { of Benefits and } \\
\text { Rewards (PPBR) }\end{array}$ & $3.84(.85)$ & $4.01(.75)$ & $3.40(.89)$ & 9.413 & $.000^{*}$ \\
\hline $\begin{array}{l}\text { Commitment to } \\
\text { Preceptor Role (CPR) }\end{array}$ & $3.79(.77)$ & $4.03(.63)$ & $3.16(.84)$ & 14.610 & $.000^{*}$ \\
\hline Satisfaction & $3.42(.81)$ & $3.61(.69)$ & $2.84(.86)$ & 12.210 & $.000^{*}$ \\
\hline $\begin{array}{l}\text { Preceptor's Perception } \\
\text { of Support (PPS) }\end{array}$ & $3.05(.89)$ & $3.23(.83)$ & $2.51(.88)$ & 10.942 & $.000^{*}$ \\
\hline Barrier Scale & $2.08(.81)$ & $1.93(.78)$ & $2.53(.75)$ & -10.327 & $.000^{*}$ \\
\hline
\end{tabular}

Ns vary based on missing data.

Scale $0=$ Strongly Disagree, $1=$ Disagree, $2=$ Somewhat Disagree, $3=$ Somewhat Agree, $4=$ Agree, $5=$ Strongly Agree.

T-test $* \mathrm{p}<0.05$. P values are for overall difference across the tables.

Table 4.16 demonstrates how all scales, including barrier total scores, were significantly correlated with all other scales $(\mathrm{p}<.01)$. Almost all the correlations were above .3 , except for the correlation between benefits and barriers, which was -.266 . The correlations among the benefits, commitment, satisfaction, and support scales were all positive. The highest significant correlation found was between commitment and satisfaction (.707), followed by commitment and benefits and rewards (.616) and commitment and support (.572). As would be expected, all other scales were negatively correlated with barriers. 
Table 4.16

Correlations among Benefits, Commitment, Satisfaction, Support, and Barrier Scale Totals

\begin{tabular}{|c|c|c|c|c|c|}
\hline Scale Totals & 1 & 2 & 3 & 4 & 5 \\
\hline $\begin{array}{l}\text { 1. Preceptor's Perceptions of Benefits and } \\
\text { Rewards (PPBR) }\end{array}$ & 1 & $.616^{* *}$ & $.518 * *$ & $.415^{* *}$ & $-.266^{* *}$ \\
\hline 2. Commitment to Preceptor Role (CPR) & & 1 & $.707 * *$ & $.572 * *$ & $-.469 * *$ \\
\hline 3. Satisfaction & & & 1 & $.545^{* *}$ & $-.524 * *$ \\
\hline 4. Preceptor's Perception of Support (PPS) & & & & 1 & $-.566^{* *}$ \\
\hline 5. Barriers & & & & & 1 \\
\hline
\end{tabular}

Ns range from 993-1150. **p < 0.01 (2-tailed). PPBR, CPR, PPS adapted from nursing literature (Dibert \& Goldenberg, 1995); Satisfaction scale adapted/modified from the satisfaction subscale of the Clinical Preceptor Experience Evaluation Tool (CPEET) (O’Brien et al., 2014); Barriers was created based on literature review, RDN feedback, pilot, etc.

\section{Research Question 4}

\section{What factors are associated with RDNs being current preceptors?}

Table 4.17 shows the correlations between the independent variables used in the analysis of the final logistic regression model to predict preceptor status. Although there were some statistically significant correlations in the table, the correlations were low <.3. Any correlations that were $>.3$, such as the scale scores also shown in Table 4.16, were not included in the final regression model secondary to the effects of multicollinearity.

Table 4.17

\section{Correlations Among Variables in Final Regression Model}

\begin{tabular}{|c|c|c|c|c|c|c|c|c|}
\hline Variables & 1 & 2 & 3 & 4 & 5 & 6 & 7 & 8 \\
\hline 1. Years RD & 1 & .054 & .037 & -.001 & $.228 * *$ & $.115^{* *}$ & .003 & -.022 \\
\hline 2. Highest Degree & & 1 & -.003 & .014 & .013 & -.056 & .043 & .055 \\
\hline 3. Specialization Credential & & & 1 & -.022 & $-.101 * *$ & $-.065^{*}$ & .031 & .029 \\
\hline 4. Commitment Scale Mean & & & & 1 & -.034 & -.019 & .053 & .042 \\
\hline 5. WorkStatus (BL) & & & & & 1 & $.071 *$ & $-.073 *$ & $-.074 *$ \\
\hline 6. Area Where you Work & & & & & & 1 & -.042 & -.054 \\
\hline $\begin{array}{l}\text { 7. On DI advisory } \\
\text { committee }\end{array}$ & & & & & & & 1 & $.169 * *$ \\
\hline 8. Work for a DI program & & & & & & & & 1 \\
\hline
\end{tabular}


A logistic regression was performed to assess the influence of several factors on the likelihood that RDN respondents would report being current preceptors. The final model contains eight independent variables (years RDN, highest degree completed, hold specialization credential, work status, commitment score, area where work or reside if not working, work for a DI program, on a DI advisory committee). The model containing all predictors was statistically significant, $\chi^{2}(12, \mathrm{~N}=984)=194.295, \mathrm{p}<.001$, indicating that the model was able to distinguish between respondents who were current preceptors and those who were not currently precepting (former + never). On the whole, the model explained between $17.9 \%$ (Cox and Snell R squared) to $24.2 \%$ (Nagelkerke R squared) of the variance in preceptor status, and correctly classified $68.7 \%$ of cases. As shown in Table 4.18, all eight independent variables made a statistically significant contribution to the model. The strongest predictors of preceptor status were working for a DI program $(\mathrm{OR}=4.071)$, being on a DI advisory committee $(\mathrm{OR}=3.333)$, holding a specialization credential $(\mathrm{OR}=1.64)$, and commitment to the preceptor role $(\mathrm{OR}=1.402)$. This indicated that when controlling for all other factors in the model, RDN respondents working for a DI program had odds of being a preceptor that were 4.071 above those who did not work for a DI program. Those on a DI advisory committee had odds that were 3.333 above those not on an advisory committee. RDNs holding a specialization credential had odds that were 1.64 above those who did not have a specialization credential. For every 1-point increase on the 6-point commitment scale, the odds of the RDN being a current preceptor increased by 1.4 . 
Each additional year a respondent was an RDN decreased their odds of being a current preceptor by .02. The odds of an RDNs holding a master's degree being a current preceptor was .716, compared to those holding a bachelor's degree and the odds of RDNs with a doctorate precepting were .303 , compared to holding a bachelor's degree. RDNs working part-time had lower odds (.619) of precepting compared to full-time and those working per diem/other had even lower odds of precepting (.078), compared to those working full-time. Those working/residing in rural areas had lower odds of being a preceptor (.451), compared to those working/residing in urban areas. 
Table 4.18

Binary Logistic Regression Analysis for Factors Predicting Preceptor Status

\begin{tabular}{|c|c|c|c|c|c|c|c|}
\hline & SE & Wald & df & $\mathbf{p}$ & $\begin{array}{c}\operatorname{Exp}(B) \\
\text { OR }\end{array}$ & $\begin{array}{r}\text { Lower- } \\
\text { bound }\end{array}$ & $\begin{array}{l}\text { Upper- } \\
\text { bound }\end{array}$ \\
\hline Years RDN & .006 & 7.108 & 1 & $.008 *$ & .983 & .971 & .996 \\
\hline Highest Degree $0=$ Bachelors (REF) & & 8.695 & 2 & $.013^{*}$ & & & \\
\hline $1=$ Masters & .146 & 5.204 & 1 & $.023 *$ & .716 & .537 & .954 \\
\hline $2=$ Doctorate & .544 & 4.826 & 1 & $.028 *$ & .303 & .104 & .879 \\
\hline $\begin{array}{l}\text { Specialization Credential } \\
0=\text { No }(\mathrm{REF}) \\
1=\text { Yes }\end{array}$ & .158 & 9.771 & 1 & $.002 *$ & 1.64 & 1.203 & 2.236 \\
\hline $\begin{array}{l}\text { BL Work Status } \\
0=\text { Full-time }(\text { REF }) \\
1=\text { Part-time } \\
2=\text { Per Diem, Other }\end{array}$ & $\begin{array}{l}.196 \\
.358\end{array}$ & $\begin{array}{c}53.615 \\
5.950 \\
50.800\end{array}$ & $\begin{array}{l}2 \\
1 \\
1\end{array}$ & $\begin{array}{l}.000 * \\
.015 \\
.000 *\end{array}$ & $\begin{array}{l}.619 \\
.078\end{array}$ & $\begin{array}{l}.422 \\
.039\end{array}$ & $\begin{array}{l}.910 \\
.157\end{array}$ \\
\hline $\begin{array}{l}\text { Area where work (reside)? } \\
0=\text { Urban }(\mathrm{REF}) \\
1=\text { Suburban } \\
2=\text { Rural } \\
3=\text { Other }\end{array}$ & $\begin{array}{l}.158 \\
.242 \\
.459\end{array}$ & $\begin{array}{c}11.691 \\
2.862 \\
10.823 \\
.001\end{array}$ & $\begin{array}{l}3 \\
1 \\
1 \\
1\end{array}$ & $\begin{array}{c}.009 * \\
.091 \\
.001 * \\
.979\end{array}$ & $\begin{array}{l}.765 \\
.451 \\
.988\end{array}$ & $\begin{array}{l}.562 \\
.280 \\
.402\end{array}$ & $\begin{array}{c}1.043 \\
.725 \\
2.430\end{array}$ \\
\hline Commitment $0-5$ scale & .096 & 12.388 & 1 & $.000^{*}$ & 1.402 & 1.162 & 1.693 \\
\hline $\begin{array}{l}\text { On a DI advisory committee } \\
0=\text { No }(\mathrm{REF}) \\
1=\text { Yes }\end{array}$ & .441 & 7.465 & 1 & $.006^{*}$ & 3.333 & 1.405 & 7.904 \\
\hline $\begin{array}{l}\text { Work for a DI program } \\
0=\text { No (REF) } \\
1=\text { Yes }\end{array}$ & .502 & 7.823 & 1 & $.005^{*}$ & 4.071 & 1.522 & 10.886 \\
\hline Model: & & & & & & & \\
\hline$\chi^{2}$ & 194.295 & & 12 & $.000^{*}$ & & & \\
\hline Cox \& Snell $\mathrm{R}^{2}$ & .179 & & & & & & \\
\hline Nagelkerke $\mathrm{R}^{2}$ & .242 & & & & & & \\
\hline $\begin{array}{l}\text { Predicted percentage correct } \\
\text { overall }\end{array}$ & 68.7 & & & & & & \\
\hline $\mathrm{N}=984$ & & & & & & & \\
\hline
\end{tabular}

Dependent variable $=$ preceptor status: $0=$ Former, Never, $1=$ Current. $0=$ reference.

Hosmer and Lemeshow Test (.797). Predicted percentage correct, overall 68.7\% (Former and Never 79.7\%, Current 52.3\%).

$* \mathrm{p}<.05$. 


\section{Chapter V \\ DISCUSSION}

This chapter provides an overview of the purpose of the study, key findings, discussion of results, study limitations, study strengths, future directions/implications for future research, implications for practice, and concluding summary.

\section{Purpose of the Study}

There has been an internship shortage compared to qualified dietetic internship applicants, as well as a limited number of volunteer preceptors for qualified dietetic students (ACEND, 2013). This survey was developed to add more to the limited body of knowledge related to the national Dietetic Internship preceptor shortage. As the Accreditation Council for Education in Nutrition and Dietetics (ACEND) is moving toward a new model, called the Future Education Model that combines a graduate degree with practice experiences, there will be the same or even a greater need for preceptors/ mentors to meet competencies that require dietetic students to demonstrate they can perform tasks in the field (https://www.eatrightpro.org/acend/accreditation-standardsfees-and-policies/future-education-model).

The purpose of this cross-sectional study was to collect data on a national sample to have a better understanding of RDNs who currently precept, are former preceptors, or 
have never precepted, the reason(s) they precept, the training and support they receive, their perception of benefits, motivators/incentives, and barriers to precepting, as well as their satisfaction with precepting, commitment to the preceptor role, and factors associated with RDNs who currently precept.

\section{Key Findings}

\section{Top Reasons RDNs Chose to Precept}

The top five reasons RDNs chose to precept or would precept were to: (1) contribute to the profession, (2) give back to the field, (3) introduce students and interns to the field, (4) get experience teaching and mentoring, and (5) considered precepting to be their professional responsibility. These reasons all had means above 3.5 on a $0-5$ scale, except "considering precepting a professional responsibility" for the never precepted group (mean 3.41), whereas the lowest means were for (1) it is required by my workplace (1.98), and (2) there are tangible benefits (1.32). This is encouraging as it seems to demonstrate a high dedication to the field and implies that with the right programs and resources, it is possible for more RDNs to precept.

\section{If It Was Solely the RDNs' Decision, Would They Precept?}

When RDNs were asked if they were involved in the final decision to precept or not to precept, while close to half of the respondents said yes, half also did not have a choice. The current and former preceptors responded yes to being involved in the final decision to precept more than those in the never precepted group. When RDNs were asked if they would precept if it was solely their decision, two-thirds of the respondents said yes $(66.9 \%)$. While the current preceptors responded yes at the highest rate $(82.0 \%)$, 
the former preceptors (61.3\%) and never precepted (54.2\%) still had a majority who responded yes. This is a positive finding. Yet, since only $37 \%$ of the sample were current preceptors, these data can help to explain why RDNs who would want to precept do not.

\section{How Incentives Influence Precepting}

RDNs somewhat disagreed that they were satisfied with the incentives offered/received for precepting, and potential incentive scores were similar across the three groups (current, former, and never preceptors). Only two incentives had statistical differences, with CPEUs for precepting being rated as a higher potential incentive for former than current preceptors and Dietetic Practice Group membership being paid being rated higher by current than never preceptors.

The potential incentive for precepting with the highest overall mean score was CPEUs for precepting, followed by expenses paid toward a national conference. However, the highest number of respondents (35.6\%) reported that they did not receive any of the incentives listed for precepting. A total of $9.3 \%$ of the participants reported they have received CPEUs for precepting, which for being on top of the list for incentives received was low, but higher than expected given that the approval for RDNs to receive CE credit for precepting is relatively new.

When specifically asked if CE credit for the act of precepting would make the RDN more likely to precept, overall the largest number of respondents (25.6\%) chose that they would precept with or without receiving CE credits for precepting. However, a large number of respondents (23.8\%) also chose yes, "receiving CE credits somewhat increases my likelihood to precept" and "maybe, if I could receive more than three credits 
a year" $(22.6 \%)$. For the RDNs who have never precepted, the primary response was also "maybe, if I could receive more than three credits a year."

Overall, these results appeared to indicate that increasing awareness of CE credits could potentially help to increase RDNs who take on the preceptor role.

\section{Perceived Benefits, Supports, Satisfaction, and Commitment}

The perceived benefits, supports, satisfaction, and commitment scales were scored 0-5, with higher scores being more positive. The total mean score for the perceived benefits was the highest 3.84 ( agree), with similar means found in each of the groups. Total commitment mean score was 3.79, total satisfaction mean score 3.42 , and support scored the lowest of the four scales with a mean of 3.05 (somewhat agree). Benefits scores were similar among the three groups of respondents. However, current and former preceptors scored significantly higher $(\mathrm{p}<.001)$ than never respondents on the other three scales, commitment $(\mathrm{C}=3.91, \mathrm{~F}=3.92, \mathrm{~N}=3.48)$, satisfaction $(\mathrm{C}=3.48, \mathrm{~F}=3.49$, $\mathrm{N}=3.24)$, and support $(\mathrm{C}=3.18, \mathrm{~F}=3.06, \mathrm{~N}=2.85)$.

All scales were positively correlated with all other scales $(\mathrm{p}<.01)$, with the highest significant correlations found between commitment and satisfaction (.707), commitment and benefits and rewards (.616), and commitment and support (.572). As would be expected, all scales were also negatively correlated with barriers.

\section{Top Reasons RDNs Stopped Precepting}

The top reason former preceptors reported they stopped precepting was because they changed jobs/positions, resigned, or retired (19.9\%). Other reasons on the list, although chosen much less frequently, included secondary to workload or short-staffed 
(5.7\%), no contract or contract issues with the internship (3.2\%), workspace limitations $(2.8 \%)$, or a change in management $(1.8 \%)$.

\section{Top Barriers to Precepting}

The top three barriers (0-5 scale) to precepting for RDNs, from a list of 23 barriers, were increased stress from having interns (mean $=3.10)$, precepting being timeconsuming/increasing workload $($ mean $=3.04)$, and a lack of incentives $($ mean $=2.77)$. For current and former preceptors, these top three barriers were the only barriers with means of greater than 2.5, midpoint on the scale. However, there were mean scores greater than the 2.5 midpoint found for 11 of the 23 barriers for RDN respondents who have never precepted.

Twenty out of the 23 barriers had significant differences across the groups, with most barriers being scored significantly lower by the current and former preceptors than the never precepted group. This indicated the RDNs who never precepted perceived more barriers to the preceptor role that those who were current or former preceptors. Thus, these data suggested that reducing barriers may be important for getting RDNs who have never precepted to take on precepting role.

\section{Training and Having an On-Call Specialist}

A large number of respondents overall $(69 \%, 802)$ reported they have not received preceptor training. However, former preceptors somewhat disagreed (2.80) they would need training before precepting a dietetic intern, while RDNs who never precepted responded significantly different, agreeing to somewhat agreeing (1.46) they would need training before precepting. RDNs who have never precepted also somewhat agreed 
overall that they would be more likely to precept if they had access to an On-Call Specialist.

\section{Factors Associated With Current Preceptors}

Several factors were found to have an influence on the likelihood that RDN respondents would report being current preceptors, including fewer years as an RDN, holding a bachelor's degree as their highest degree, holding a specialization credential, working full-time compared to part-time/per diem/other, working/residing in urban areas compared to rural settings, working for a DI program, being on a DI advisory committee, and having higher commitment scale scores.

\section{Discussion of Results}

\section{Characteristics of Registered Dietitian Nutritionists}

A total of 1,170 RDNs completed at least one scale in the survey and therefore were included in the final sample, consisting of 434 (37.1\%) current preceptors, 393 (33.6\%) former preceptors, and $343 \mathrm{RDNs}$ who have never precepted (29.3\%) dietetic interns. This breakdown is rather similar to another national survey of RDNs, per a poster session abstract (Arnold et al., 2016), where they recruited 1550 RDNs and found 70.8\% of participants to be current or former preceptors and $25.8 \%$ reported never being asked to precept. In this study, respondents reported being an RDN an average of 17 years. Former preceptors had been in the field about 21 years, significantly longer than current preceptors (15) and RDNs who have never precepted (16). About $81 \%$ of RDNs (947) were currently working in the field, with $80.6 \%$ of current preceptors working full-time, which is significantly higher than expected, while $52.7 \%$ of former preceptors and $48.1 \%$ 
of the never respondents both reported working full-time significantly less than expected. Twelve percent of current preceptors worked part-time and $1.4 \%$ per diem/other, both significantly lower than would be expected. RDNs reported being in their current/recent position for about 8 years. Participants responded from all 50 states, Washington, DC, and Puerto Rico, and participants worked/resided in mostly urban areas (44.2\%), followed by suburban areas $(33.1 \%)$. Current preceptors worked/resided in urban areas significantly higher than expected (54.4\%), while never preceptors responded significantly lower than expected to be in urban areas $(32.7 \%)$ and significantly higher than expected in suburban (35.6\%) and rural areas (12.2\%). Participants had a mean age of 44 and former preceptors were significantly older (48 years) than the current (41 years) and never (43 years) precepted groups.

Participants were mostly female $(86.9 \%)$ and identified as White $(81.4 \%)$ nonHispanic $(84.4 \%)$, with a mean age of 44 . These results were expected, as the field is typically known to be mostly female and "White." Respondents from the national survey of RDNs mentioned previously (Arnold et al., 2016) were 96.1\% female, $88.2 \%$ "White," and had a mean age of 41.55 years. At the completion of this dissertation, 102,430 RDs and RDNs were registered through the Commission on Dietetics Registration, the credentialing agency for the Academy of Nutrition and Dietetics, and of the RDNs who reported their gender, $87 \%$ were female and $3.8 \%$ male, with the majority of the RDNs (74\%) identifying as "White"; however, $10.5 \%$ chose not to report their ethnicity (CDR, accessed 4/25/2019). There are current efforts to diversify the field, such as Diversify Dietetics (diversifydietetics.org). 
In this study, around 50\% of participants held a master's degree in a nutrition/ dietetics-related field, $38 \%$ a bachelor's, and $2.5 \%$ a doctorate. Twenty-five percent held a specialization credential in the field, with the highest group holding a specialization credential to be current preceptors at 34.1\% - significantly higher than expected. Among the credentials held by current preceptors, the largest group of respondents were Certified Nutrition Support Clinicians (7.8\%)—also significantly higher than expected.

Approximately $17 \%$ of the RDNs were teaching outside of the preceptor role.

Fifty-three percent of respondents were Academy of Nutrition and Dietetics (AND) members and 7\% were members of the Nutrition and Dietetics Educators and Preceptors dietetics practice group of AND. About 24\% held professional leadership positions in nutrition/dietetics, with current preceptors holding a leadership position significantly higher than expected $(29.3 \%)$ and RDNs who have never precepted significantly lower than expected (16.6\%). The current preceptors responded significantly higher than expected for working for a DI program $(5.1 \%)$ as well as being on a DI advisory committee $(5.8 \%)$.

RDNs (54\%) responded that they, as interns, mostly attended a college/universitybased internship program, followed by attending a hospital/health care facility-based DI (22\%); $8.5 \%$ reported they were part of a distance learning DI program. On a scale of $0-3$, the satisfaction they reported when they were interns with their own preceptors was 2.35, between satisfied to very satisfied on the scale, with all three groups of participants responding in a similar way.

Being a preceptor was not required but was allowed for $53 \%$ of respondents and was required for $21 \%$ of respondents, with current preceptors responding significantly 
higher than expected that it was required (42.9\%) and former $(15.5 \%)$ and never $(0 \%)$ responding significantly lower than expected. Only $8.1 \%$ of former and $7.3 \%$ of never respondents reported precepting was not allowed or against policy. Twenty-one percent of never respondents reported there were other RDNs at their most recent workplace who have precepted in the last 12 months, and $29 \%$ of former preceptors also reported other RDNs precepting in the workplace in the past 12 months.

The last time former preceptors reported precepting overall was an average of 7 years ago, and although $59 \%$ reported being eligible to precept, only $25.7 \%$ reported they knew how to sign up. While $40 \%$ of RDNs who have never precepted reported they were eligible to precept, only $17.5 \%$ of the never respondents reported ever being asked to precept and only $12 \%$ reported knowing how to sign up — significantly lower than expected.

Participants reported precepting a mean of about 7 years and current preceptors closer to 8 years, significantly higher than former preceptors (5.5 years). Typically, participants were precepting about three to four interns a year. Around $42-43 \%$ of current and former preceptors reported they were always the intern's primary preceptor and about $26-32 \%$ reported they were sometimes the primary preceptor. Typical weeks interns are assigned to the RDN are 5, with a mean of about 28 hours per week, estimating a typical total of 140 hours per rotation. Close to $53 \%$ of current and former preceptors typically precepted interns in an inpatient clinical/Medical Nutrition Therapy setting, with the majority in a hospital setting (37-42\%). The next largest response for the typical preceptor rotation was outpatient Medical Nutrition Therapy and community nutrition, with $30-32 \%$ of current and former preceptors responding from this group. About $14 \%$ of 
former preceptors typically supervised interns in nursing homes or transitional care units and only about $2.5 \%$ during research rotations; however, the responses were significantly higher than expected, while current preceptors usually precepted students in similar rotations, lower than expected-9\% and $1.6 \%$, respectively. The primary practice area for those who have never precepted was health care (35\%). As a reference, according to the Academy/CDR database (January 25, 2016), in the year the RDN list for this study was obtained, the highest self-reported areas of practice also included general clinical nutrition $(19,530,20.6 \%)$ and community nutrition $(7,545,8.0 \%)$.

All respondents were asked if they had received preceptor training and $22 \%$ responded yes while $69 \%$ responded no, with $38.9 \%$ of the current preceptors reporting they received training and $57.1 \%$ reporting they did not receive training. Dietetics preceptors have been found to have low scores regarding preparation for the preceptor role, with $58 \%$ indicating in an earlier study that they did not receive training (Marincic \& Francfort, 2002)

\section{Research Question 1}

What incentivizes or motivates RDNs currently in the preceptor role to precept? What would motivate more RDNs to take on the preceptor role?

Incentives received and satisfaction with incentives. On a scale of $0-5$, on the satisfaction with incentives offered, received, with higher scores indicating more satisfaction, RDNs somewhat disagreed (mean $=1.98$ ), with the never precepted group $($ mean $=2.19)$ responding significantly higher than the current $($ mean $=1.92)$ and former preceptors $($ mean $=1.90)$. This finding is important since overall, they were saying they were somewhat unsatisfied. The reason why the never precepted group may have 
responded higher, although still close to somewhat disagree, could be because RDNs who have never precepted may be somewhat more intrigued by and interested in receiving incentives, whereas current and former preceptors may be more familiar with the actual incentives being received in the field, which were reported as few in this study as well as indicated in previous research (Marincic \& Francfort, 2002).

A total of $9.3 \%$ of the participants reported they received CPEUs for precepting, which was low for being the top incentive in this study; however, it was higher than was expected, given the approval for RDNs to receive CPEU credit for precepting was new. Second on the list was only $7.7 \%$ of respondents reporting they received peer/public recognition, $7.3 \%$ CPEU general offerings, $3.6 \%$ a reduction in their regular workload, $2.6 \%$ access to library resources, $2.2 \%$ pay or monetary compensation/gift card, and $2.1 \%$ hot topic/best practice updates. The highest number of respondents $(35.6 \%)$ reported that they did not receive any of the 14 incentives listed for precepting, which included being given the option to enter others with free text. These findings were similar to the 2002 finding by Marincic and Francfort, where a low percentage of preceptors (8\%) reported receiving tangible rewards, and to the study by Winham et al. (2014) of a convenience sample of dietetic and nutrition professionals in Arizona, in which 93\% of current preceptors reported they did not receive extra monetary compensation.

The incentives that were at the very bottom of the list in the current study, each received by less than $1 \%$ of RDNs, included expenses paid toward a national conference, AND membership fee paid, CDR annual fee paid, and DPG membership fee paid. Important to note regarding these bottom categories is that some employers were covering fees in this area as an employee benefit or reimbursing fees through an approval 
process. Thus, these may not be incentives for precepting for some RDNs since employees pay them whether or not RDNs precept, but since they were listed higher on the potential incentives list for RDNs in this study, it seems there may still be a number of RDNs who did not have these fees reimbursed; for those RDNs, this could be more of an incentive.

Potential incentives for precepting. The potential incentives that were scored highest (most desirable) for RDNs were: (1) CPEUs for the act of precepting, (2) expenses paid toward a national conference, (3) CDR annual fee paid, (4) AND membership fee paid, and (5) pay or monetary compensation/gift card. CPEUs for precepting were also at the top of the list for former preceptors and RDNs who have never precepted; however, the incentive at the top of the list for the current preceptor group was expenses paid toward a national conference. Nonetheless, CPEUs for precepting were still the current group's second top incentive. On a scale of $0=$ not very likely to $2=$ very likely, the mean score for CPEUs for precepting for current preceptors $($ mean $=1.44)$ was significantly lower than for former preceptors $($ mean $=1.54)$. Although not in the top incentives, there was a significant difference in the current preceptors' mean score for DPG membership paid as a potential incentive $($ mean $=1.15)$ and those who have never precepted (mean $=.98)$. Only two statistically significant differences were found between the group means out of the 14 incentives, and no statistically significant differences were found in the scores between the former preceptors and those who have never precepted in relation to potential incentives.

In a study by AbuSabha et al. (2018) of clinical dietitians ( $N=100)$ CE units were rated as the greatest potential motivator. Also in a study by Winham et al. (2014) of a 
convenience sample of dietetic and nutrition professionals in Arizona $(\mathrm{N}=552)$, of current, former and never preceptors all eligible to precept, the preferred incentive (nonmonetary) for being a preceptor was CE credits for the field, followed by expenses paid to a national conference, which was similar to the present findings; however, in these findings, the question was asked separately about CEs for the act of precepting, which, as indicated above, were at the top on the list in this study, while CE offerings (not including for the act of precepting) were lower on the list of potential incentives. Also, the top preferred incentives in the Arizona study was "pay for my time," which was also in the top five potential incentives in this study. Some of the nutrition and dietetics professionals in the Arizona study reported they would precept without incentives, but more responses showed that specific rewards, such as the ones listed here, would encourage them to take an intern. They also discussed how support for the preceptor role could be more important in motivating professionals to precept than monetary benefits.

In another study of dietetics preceptors by Taylor et al. (2010), some respondents did feel they should be compensated, while in the study by Winham et al. (2014), only $33 \%$ of the preceptors reported receiving a satisfactory amount of monetary compensation.

The potential incentives scoring the lowest overall in the current study were faculty appointment and/or faculty benefits/development opportunities, access to library resources, hot topic/best practice updates, official designation/title for being a preceptor, and peer/public recognition.

Access to an On-Call Specialist also came up in the list of preferred incentives in the Arizona study (Winham et al., 2014), although there were significant differences in 
responses between preceptors and nonpreceptors. In the current study when former and never preceptors were asked on a scale of $0-5$ if they would be more likely to precept if they had access to an On-Call Specialist, those who have never precepted somewhat agreed $($ mean $=1.94)$, while former preceptors responded significantly different, closer to somewhat disagreeing $($ mean $=2.73)$ with the statement.

More on continuing education credits for precepting as an incentive. The offering of continuing education credit for the act of precepting in dietetics in the United States began in June 2017. Most of the RDNs (64\%) in this study did not know they could receive $\mathrm{CE}$ credit for precepting; however, current preceptors (45.4\%) were more familiar with this option than the former $(17 \%)$ and never $(12.5 \%)$ respondents. This was not surprising given that it is a new offering; however, it is also an area that can be highlighted more to RDNs since it also came up as the top potential incentive in this study.

Regarding receiving CE credit for the act of precepting and if it would make RDNs more likely to precept, the largest number of total respondents (25.6\%) chose that they would precept with or without receiving $\mathrm{CE}$ credits for precepting, when asked if $\mathrm{CE}$ credit for precepting would make them more likely to precept. Coming in second was $23.8 \%$ of respondents overall choosing yes, receiving CE credits somewhat increases their likelihood to precept, and $22.6 \%$ chose maybe, if they could receive more than three credits a year. The least chosen response overall (7.4\%) was yes, receiving CE credits for precepting greatly increases my likelihood to precept.

There was a significant association between preceptor status and whether receiving CE credit for precepting would make the RDNs more likely to precept, with 
current preceptors $(36.6 \%)$ responding higher than expected that they would precept with or without CE credits and never (12.0\%) responding lower than expected. Never preceptors' primary response to this question, which was significantly higher than expected, was maybe, if I could receive more than three credits a year (27.4\%). The response that no number of $\mathrm{CE}$ credits would make it more likely for them to precept was chosen significantly higher than expected for the never RDNs (13.4\%) and significantly lower than expected for the current preceptors $(6.0 \%)$.

RDN involvement in decision to precept. When RDNs were asked if they were involved in the final decision to precept or not to precept, $37.2 \%$ responded yes and $34.9 \%$ no. The current preceptors $(53 \%)$ responded significantly higher than expected that they were involved in the final decision to precept, while the never group $(9.9 \%)$ responded significantly lower than expected, although this makes sense given that current preceptors are actively in the role and never are not.

When RDNs were asked if they would precept if it was solely their decision, twothirds $(66.9 \%)$ of respondents said yes, which is a very positive finding. Additionally, over half of respondents in all three groups said yes. There was a significant association between preceptor status and if they would precept if it was solely their decision, with current preceptors $(82 \%)$ responding yes significantly higher than expected and former preceptors $(61.3 \%)$ and never precepted (54.2\%) groups responding significantly lower than expected.

Reasons RDNs precept or would precept. The top five reasons RDNs chose they precepted or would precept were to: (1) to contribute to the profession, (2) give back to the field, (3) introduce students and interns to the field, (4) get experience teaching and 
mentoring, and (5) considering it to be their professional responsibility. The current and former participant groups also chose the same top five reasons from those listed. The never group shared four of the top five reasons with the current and former preceptors. The difference was number four, it is my professional responsibility. Although it was close, this was the sixth reason in the never group. The fourth reason for precepting for the never group was to learn from the intern/keep up-to-date. Current and former preceptors did score significantly higher than those who have never precepted on the top four reasons and current preceptors also scored significantly higher than those who had never precepted for the reason "to network/stay connected."

The two reasons with the overall lowest scores were "it is required for my workplace" and "there are tangible benefits...," with significant differences between all three groups on these bottom two reasons. Current preceptors scored significantly the highest, with former in the middle and the RDNs who never precepted scoring the lowest.

\section{Research Question 2}

\section{What are the barriers to precepting for RDNs?}

Reasons former preceptors stopped precepting. The top reason former preceptors $(\mathrm{N}=373)$ reported they stopped precepting was since they changed jobs/positions, resigned, or retired (19.9\%). Other reasons higher on the list, although chosen much less frequently, included secondary to workload or short-staffed (5.7\%), no contract or contract issues with the internship (3.2\%), workspace limitations (2.8\%), a change in management $(1.8 \%)$, not working or on a leave of absence $(1.7 \%)$, unable to demonstrate added value of precepting interns (1.4\%), or stress or personal circumstances $(1.2 \%)$. 
Barriers to precepting. On a scale from $0=$ strongly disagree to $5=$ strongly agree, the top barrier means to precepting for RDNs found in this study included increased stress from having interns (3.10), time-consuming/increased workload (3.04), and a lack of incentives (2.77). The top three barriers were also the extent of the barriers with means of greater than 2.5 , midpoint on the scale, for current and former respondents, while the mean scores of 11 of the barriers for RDNs who never precepted were greater than the 2.5 midpoint. RDNs who have never precepted seem to rate barriers higher than RDNs who are current or former preceptors.

Responses to 20 of the 23 barriers listed in the survey, including the top three barriers, were found to have statistically significant differences in their responses between the groups. The mean score for former preceptors (2.77) for increased stress from having interns, the top barrier, was significantly lower than the mean scores for current (3.30) and never (3.22). This implied that former preceptors viewed increased stress from having interns as less of a barrier than current and never, although the mean score for former was still above the midpoint on the scale. This was also the case for the second barrier, time-consuming/increased workload, where former preceptors (2.75) responded significantly lower than current (3.16) and never (3.23), as well as for the barrier quality of the intern, with former (1.77) responding lower than current (2.05) and never (2.11).

For 12 of the barriers, including a lack of incentives, barrier three on top of the list, the mean scores for RDNs who never precepted were consistently significantly higher than the mean scores for former and never preceptors, indicating they agreed higher with the items listed being barriers. Five of the barriers later in the list (legal 
issues, liability/regulatory concerns, length of intern onboarding process, restricted by the facility or management, and not enough for interns to do at my workplace) also had significantly different means, with the differences found among all three groups. The differences across the five barriers all indicated higher scores in the never group, followed by the former and lowest scores for current preceptors. The three barriers where the groups responded similarly, with no statistically significant differences found in responses, were short-staffed or downsizing, lack of appreciation/recognition, and negative experience with internship program/prior intern.

In the study by Winham et al. (2014) of dietetic and nutrition professionals in Arizona, the possible barriers to precepting interns included workload, intern liability, lack of compensation, lack of support, and lack of knowledge on becoming a preceptor, with only $17 \%$ aware of how to become a preceptor. One of the big concerns in this study was having time to do work as well as time to train the interns. In the 2016 national study by Arnold et al. $(\mathrm{N}=1550)$, inadequate time was also seen as the main barrier across current, former, and never RDNs and in a study by AbuSabha et al. (2018) of clinical dietitians ( $\mathrm{N}=100$, preceptors and non-preceptors), they also reported lack of time as the biggest barrier.

Confidence to precept, preceptor training. Winham et al. (2014), in their study specific to dietetic and nutrition professionals in Arizona $(\mathrm{N}=552)$, found that nonpreceptors did not report an equivalent level of confidence as former and current preceptors in their "ability to precept effectively." In the current study, on a scale of $0=$ strongly disagree to $5=$ strongly agree, former preceptors agreed $($ mean $=4.06)$ with the statement "I would be an effective preceptor," and also responded significantly higher 
than RDNs who have never precepted (mean $=3.72$ ), although never preceptors did respond close to agree as well. Former preceptors also agreed (mean $=4.04)$ with the item "I am confident I have the knowledge and skills to precept," responding again significantly higher than respondents who never precepted (mean $=3.58)$.

Former preceptors somewhat disagreed $($ mean $=2.80)$ they would need training before precepting a dietetic intern, while RDNs who never precepted responded significantly different, agreeing to somewhat agreeing $($ mean $=1.46)$ they would need training before precepting. When all respondents were asked if they had received preceptor training, $22 \%$ responded yes, with about $15 \%$ receiving formal training and about $16 \%$ receiving informal training. There was a larger than expected number of respondents $(69 \%)$ reporting they have not received preceptor training. Dietetics preceptors have been found to have low scores regarding preparation for the preceptor role, with $58 \%$ indicating no training, $32 \%$ informal training, and $10 \%$ formal training in a 2002 study of 116 dietetic preceptors (Marincic \& Francfort). In another study of dietetics preceptors $(\mathrm{N}=265,95.4 \% \mathrm{RDs}), 30.2 \%$ of respondents participated in formal training and $87.9 \%$ indicated training materials for precepting would be advantageous (Wilson, 2002).

\section{Research Question 3}

What are the RDs perceived benefits, support, satisfaction, and commitment

\section{to the preceptor role?}

Total mean scores for the perceived benefits were the highest, mean $=3.84$

( agree), with similar means found in each of the groups. Total commitment mean score was 3.79, total satisfaction mean score was 3.42, and support scored the lowest of the 
four scales with a mean of 3.05 (somewhat agree). Current and former preceptors also scored significantly higher than never precepted respondents on these three scales: commitment $(\mathrm{C}=3.91, \mathrm{~F}=3.92, \mathrm{~N}=3.48)$, satisfaction $(\mathrm{C}=3.48, \mathrm{~F}=3.49, \mathrm{~N}=3.24)$, and support $(\mathrm{C}=3.18, \mathrm{~F}=3.06, \mathrm{~N}=2.85)$.

All scales, including barrier total scores, were significantly correlated with all other scales. The correlations among the benefits, commitment, satisfaction, and support scales were all positive. The highest significant correlations were found between commitment and satisfaction (.707), followed by commitment and benefits and rewards (.616), and commitment and support (.572). As would be expected, the total barriers scale was negatively correlated with all other scales. This indicates that higher barriers were associated with lower benefits, support, satisfaction, and commitment.

A strong commitment towards DI programs as well as to the preceptor role was seen in a previous dietetics study by Marincic and Francfort (2002). A positive correlation was also found in this 2002 study between commitment and perceived support, with lower scores seen in support than in benefits and rewards and commitment, similar to the present findings as well. Commitment to the preceptor role in nursing has also been positively associated with a preceptor's perception of support (Blum, 2014; Dibert \& Goldenberg, 1995; Hyrkas \& Shoemaker, 2007; Natan et al., 2014) and perception of benefits and rewards (Dibert \& Goldenberg, 1995; Hyrkas \& Shoemaker, 2007; Natan et al., 2014).

On a scale of 0-5, the top means overall of the nine items included in the commitment to the preceptor role scale were: (1) "I care about the fate of the preceptors conducting supervised practice in dietetics" (mean $=4.06=$ agree), (2) "deciding to be a 
preceptor was/would be a mistake on my part" (mean $=4.05=$ disagree), (3) "being a preceptor inspires me/would inspire me to perform my best" ( $m e a n=4.01=$ agree $)$, and (4) "my philosophy of practice and the expectations of the preceptor role are aligned" $($ mean $=3.95=$ agree $)$. Statistically significant differences among the three groups were found for all nine of the statements in the scale, with the biggest difference and lowest scores seen in the never group of RDN respondents.

The lowest scored statement on the commitment scale overall was "I feel a sense of loyalty to the preceptor role" ( mean $=3.42$ ), with all three groups responding significantly different from the other and never responding the lowest, somewhat agreeing with the statement (means: $\mathrm{C}=3.72, \mathrm{~F}=3.51, \mathrm{~N}=2.92$ ).

On a scale of $0-5$, the top means overall of the six items included in the satisfaction scale related to the preceptor role were: (1) "it is stimulating to work with enthusiastic interns" (mean = 4.0 = agree), (2) "I enjoy the intern/preceptor interaction" (mean $=3.76 \sim$ agree), and (3) "the role of preceptor is professionally rewarding" (mean = $3.62=$ somewhat agree to agree). Statistically significant differences among the three groups were found for all six of the statements in the scale, with the biggest difference and lowest scores seen throughout most of the items in the never group of RDN respondents.

On the bottom of the list of satisfaction mean scores by item was "I am satisfied with the incentives offered/received for precepting," with RDNs somewhat disagreeing with the statement $($ mean $=1.98)$, also discussed under Research Question 1 related to incentives. The second lowest score in the items in the satisfaction table was under the 
never group with a mean of $3.30, \sim$ somewhat agreeing that "being a preceptor is satisfying."

The analysis of the means of the nine items included in the support scale on a scale of 0-5 was as follows: (1) "co-workers are typically supportive of RDs when they function as a preceptor" (mean $=3.46)$, and $(2)$ "management/administration are supportive of RDs in the preceptor role" (mean $=3.33$ ). Statistically significant differences among the three groups were found for the top six of the nine statements in this scale, with the biggest differences and lowest means seen in the never group of RDN respondents.

The lowest scoring statement on the list of support means was "there are adequate opportunities for preceptors to share information with other preceptors" $($ mean $=2.53=$ somewhat disagree to somewhat agree). The second lowest score in the table was "the workload of an RD is still manageable when functioning as a preceptor" (mean $=2.63)$, followed by "support is available to help preceptors develop in their role" $($ mean $=2.89=$ somewhat agree) and "preceptors have adequate preparation for their role" (mean $=2.89$ $=$ somewhat agree).

\section{Research Question 4}

\section{What factors are associated with RDNs being current preceptors?}

When a logistic regression was performed to assess the influence of several factors on the likelihood that RDN respondents would report being current preceptors, the best model included the following eight independent variables: years RDN, highest degree completed, specialization credential held, work status, commitment score, area where work or reside if not working, work for a DI program, and on a DI advisory 
committee. The full model containing all predictors was statistically significant, indicating that the model was able to distinguish between respondents who were current preceptors and those who were not currently precepting. On the whole, the model explained between $17.9 \%$ and $24.2 \%$ of the variance in preceptor status and correctly classified $68.7 \%$ of cases. All eight independent variables made a statistically significant contribution to the model. The strongest predictors of preceptor status were working for a DI program, being on a DI advisory commitment, holding a specialization credential, and commitment to the preceptor role. When controlling for all other factors in the model, RDN respondents working for a DI program were 4.071 times more likely to be a current preceptor, those on a DI advisory committee were 3.333 times more likely, RDNs also holding a specialization credential were 1.64 times more likely, and those with higher commitment scale scores were 1.402 times more likely to be a preceptor than those who had lower commitment scores.

The results of this study showed that a significant but small negative association was found with years the respondent has been an RDN, with each additional year decreasing the likelihood of being a preceptor by about $2 \%$. For education, there was a $28 \%$ decrease in being a preceptor for people who have a master's degree (compared to bachelor's) and a 70\% decrease in being a preceptor with having a doctoral degree. RDNs working full-time were more likely to precept compared to those working parttime and per diem/other; RDNs working/residing in urban areas were more likely to precept than those in rural areas. 


\section{Study Limitations}

Study inclusion was defined to Registered Dietitian Nutritionists in the United States. Thus, study results cannot be generalizable to dietitians outside of the United States. Also, since preceptors do not need to be RDNs, study results cannot be generalizable to all dietetic internship preceptors.

The list of RDNs was obtained in April 2016 and the survey was sent out in 2018. Therefore, people who became RDNs since 2016 were not on the list and also some RDNs may have provided new e-mails to CDR; thus, fewer e-mails may have bounced back with a newer list.

A raffle and second reminder e-mail were added to increase the survey response rate. There was a drop-off rate of RDN respondents during the survey, typical for an online survey of this length.

While a $13.4 \%$ response rate is typical for this kind of survey sent to a randomly selected group from a population, we cannot know how the RDNs who did not participate differ from those who did participate. Also, there are no data on the percentage of RDNs who are current, former, and never preceptors and thus no way to know if the distributions of the three groups represent the distribution of the profession, although the survey was sent to a randomly selected sample of RDNs.

\section{Study Strengths}

A large randomly selected sample of RDNs came from the main CDR list of all RDNs in the United States. This study focused on RDNs who were current preceptors, former preceptors, as well as RDNs who have never precepted. This study seems to be 
unique in the dietetics literature for finding RDN characteristics that are associated with being a current preceptor.

\section{Future Directions}

For this study, there was no data to refer to on what percentage of all current RDNs are preceptors, former preceptors, or never precepted. National baseline data are needed and could be obtained if ACEND included a question when RDNs pay the annual CDR registration fees. This baseline data for all RDNs would be valuable as a reference and for future research.

This study also warrants further investigation into stress from having interns. RDNs reported this stress as their top barrier. Future research needs to investigate where this stress may be coming from. Is it internal for the RDNs vs. external from the processes and structures at worksites? Is it both? What is at the core of this stress and how can it be most effectively addressed in this population?

Future research could also focus on what may be seen in the field in relation to commitment, satisfaction, perceived support, barriers, and number of RDNs precepting, when training, support and incentives are increased, barriers decreased and the future education model and the associated experiential learning component is implemented.

\section{Implications for Practice}

Since the RDNs somewhat disagreed that they were satisfied with incentives received/offered for precepting, offering more incentives especially in the initial recruitment process may entice RDNs to take on the preceptor role. These incentives could be chosen from the items valued higher on the list of potential incentives, such as 
expenses paid toward a national conference, AND membership fee paid, and CDR annual fee payments. Many of the items on the top of this list may not be that costly or if they cannot be offered to all preceptors in a program, maybe they can be offered initially as an onboarding incentive and then an increased number can continue to be raffled off or awarded each year. These incentives may be worked out to be paid by the internships themselves, through AND or ACEND programs or discounts and/or possibly through employers.

Most of the RDNs (64\%) in this study did not know that they could receive continuing education credit for precepting; however, current preceptors (45.4\%) were more familiar with this option than the former (17\%) and never (12.5\%) respondents. This is not surprising, given that it is a new offering. However, it is also an area that can be highlighted more to RDNs since it came up at the top of the list of potential incentives. Although most current preceptors reported they would precept with or without CE credit, offering three credits per year for precepting may not be enough incentive for some RDNs and CPEU offerings for precepting should continue to be monitored. This discussion could be conducted with ACEND to better promote the availability of CE credits for precepting and also to consider increasing the number of credits that could be earned by precepting.

Strategies that can promote RDNs to take on the preceptor role, such as conducting recruitment efforts with RDNs who hold specialization credentials, are supported by the regression model, in terms of predicting current preceptor status. This could also help provide more in-depth training for interns. 
Evaluating why RDNs who have never precepted are not as involved in the final decision to precept could help understand more about how they can be involved in this decision. This would be likely to assist more RDNs in becoming preceptors, especially since 54\% of the never group responded they would precept if it was solely their decision. Also, ensuring all RDNs know how they can become a preceptor seems crucial since many never as well as former respondents reported they did not know how to sign up to become a preceptor.

Increasing communication between program coordinators and RDNs could assist in strategizing ways to increase commitment and correlated scales, e.g., satisfaction and perceived support, especially for those who have never precepted, given the significantly lower scores seen in this group in this study.

Direct actions that can be taken to address barriers include minimizing stress, strategizing ways to decrease time/workloads of preceptors, increase incentives, increase training, increase support, assist with workspace limitations, and assess legal/liability/ regulatory concerns and issues with the length of the intern onboarding process. Also, increasing the familiarity of RDNs to/with the internship programs starting early, as well as with those who are already in the field and have never precepted, could include visiting or reaching out to more RDNs in creative ways. In addition, since so many more barriers were viewed as higher for those who have never precepted, it is necessary to look further into how these barriers could assist in bringing more RDNs onboard to precept.

Increasing preceptor support and training and ensuring pertinent topics are included related to stress reduction and other pertinent barriers in the list would be helpful, as well as designing and offering different training programs for RDNs who have 
never precepted and others for current and former preceptors. An aspect of this training could include starting early during the internship, which began per an update in the 2017 accreditation standards which includes, for example, interns role-playing precepting; this was also highlighted recently as part of an article series by the Nutrition and Dietetics Educators and Preceptors (NDEP) group, emphasizing the importance of "planting the seed" (p. 1817) to being a preceptor during the students' supervised practice experience (Roofe \& Landry, 2018). Earlier research has also suggested training preceptors in adult learning, teaching, and coaching skills, time management, and approaches for providing feedback to help establish a more successful and time-efficient preceptorship for all parties involved (Taylor et al., 2010).

\section{Conclusion}

As our health care needs increase, so will the need for RDNs. The RDN profession is moving toward a model that will combine supervised practice with a graduate degree, currently called the Future Education Model. This study provided valuable insights into increasing RDNs who become preceptors, especially during this transition in preparing RDNs. RDNs can be recruited as preceptors as they start their career. Training for precepting can be widely provided. More incentives can be provided. Places that employ RDNs can adjust workloads to create the time and space and reduce stress for RDNs to precept. RDNs can be recruited onto advisory committees to connect them to the preceptor role. The data from this study can have value for RDNs as a whole to create meaningful precepting experiences. These data also have value for ACEND, employers, universities, and dietetic internships to build commitment, supports, and 
incentives, as well as to decrease barriers so that more RDNs choose to take on the role of precepting the future of the dietetics profession. 


\section{REFERENCES}

AbuSabha R, Muller C, MacLasco J, George M, Houghton E, Helm A. J Acad Nutr Diet. 2018 Mar;118(3):471-480.

Academy of Nutrition and Dietetics (AND). Academy groups. http://www.eatrightpro. org/resources/membership/academy-groups. Accessed 10/8/2016.

Academy of Nutrition and Dietetics (AND). Definitions of terms list. Updated 4/2014.

Academy of Nutrition and Dietetics (AND). Every registered dietitian is a nutritionist, but not every nutritionist is a registered dietitian. http://www.eatright.org/ HealthProfessionals/content.aspx?id=6859\&terms=RDN. Accessed 4/25/2013.

Academy of Nutrition and Dietetics (AND). Evidence Analysis Library (EAL). MNT: Disorders of lipid metabolism. 2015. https://www.andeal.org/topic.cfm?menu $=5284 \&$ cat $=4070$. Accessed 1/4/2017.

Academy of Nutrition and Dietetics (AND). Evidence Analysis Library (EAL). MNT: RDN in medical team. 2015. http://www.andeal.org/topic.cfm?format_ tables $=0 \& m e n u=5284 \&$ cat $=5233$. Accessed 1/4/2017.

Academy of Nutrition and Dietetics (AND). Evidence Analysis Library (EAL). MNT: Telenutrition interventions by registered dietitians. 2012. http://www.andeal. org/topic.cfm?format_tables $=0 \& m e n u=4706 \&$ cat=4907. Accessed 1/4/2017.

Academy of Nutrition and Dietetics (AND). Evidence Analysis Library (EAL). MNT: Weight management. 2015. Accessed 1/4/2017.

Academy of Nutrition and Dietetics (AND). Future Education Model graduate programs. eatright.org, eatrightPRO. Accessed March 31, 2019.

Academy of Nutrition and Dietetics (AND). NDEP. Call for preceptors. NDEP-Line Spring 2013.

Academy of Nutrition and Dietetics (AND). NDEP. Celebrate National Preceptor Month. NDEP-Line Spring 2013.

Academy of Nutrition and Dietetics (AND). Online nutrition care manual, Conditions: Diabetes, Hypercholesterolemia, Hypertension, Hypertriglyceridemia, Oncology General Guidance, Osteoporosis. Accessed 1/4/2017.

Academy of Nutrition and Dietetics (AND). RD = Nutrition Expert. http://www.eatright. org/HealthProfessionals/content.aspx?id=6856. Accessed 4/25/2013. 
Accreditation Council for Education in Nutrition and Dietetics (ACEND). ACEND accreditation decisions. ACEND Connection-Online Update February 2013.

Accreditation Council for Education in Nutrition and Dietetics (ACEND). ACEND's dietitian job outlook. http://www.eatrightacend.org/ACEND/content.aspx?id $=6442485538$. Accessed 4/23/2016.

Accreditation Council for Education in Nutrition and Dietetics (ACEND). April has been declared National Preceptor Month. ACEND Connection - On-Line Update February 2013.

Accreditation Council for Education in Nutrition and Dietetics (ACEND). Availability of dietetic internship positions. Supply and Demand for Internship Sites. http://www.eatrightpro.org/resource/acend/students-and-advancing-education/ dietetic-internship-match-students/availability-of-dietetic-internship-positions. Accessed 7/3/2017.

Accreditation Council for Education in Nutrition and Dietetics (ACEND). Connection April 2012.

Accreditation Council for Education in Nutrition and Dietetics (ACEND). Connection September 2012.

Accreditation Council for Education in Nutrition and Dietetics (ACEND). Frequently asked questions. Future Education Model Accreditation Standards for Programs in Nutrition and Dietetics. March 2018.

Accreditation Council for Education in Nutrition and Dietetics (ACEND). How do other professions avoid a shortage of internship preceptors? http://www.eatright.org/ ACEND/content.aspx id=6442475687\&terms=internship\%20shortages. Accessed 4/18/2013.

Accreditation Council for Education in Nutrition and Dietetics (ACEND). Preceptors or mentors: How can I help to eliminate the internship shortage? http://www.eat right.org/ACEND/content.aspx $? \mathrm{id}=6442464994$ \&terms=preceptor. Accessed 2/5/2013.

American Academy of Family Physicians (AAFP). Community precepting: Benefits of practices. Fam Pract Manag. 2012 Mar-Apr;19(2):8.

American Heart Association (AHA). 2013 Statistical fact sheet: 2020 Impact Goal.

Arnold C, Amescua M, Bulifant R, Burton M, Grotto D, Kazimi S, Parsons K, Smithson T. Barriers and motivators to /mentoring dietetic internship students. J Acad Nutr Diet. 2016 Sept;116(9):A73. (Poster Session: Abstract) 
Bergman EA. Academy President update. Keep making history: Academy of Nutrition and Dietetics. Spring 2013 ppt.

Blum CA. Evaluating preceptor perception of support using educational podcasts. Intl J Nurs Ed Scholarship. 2014;11(1):1-8.

Bureau of Labor Statistics, U.S. Department of Labor. Occupational outlook handbook, dietitians and nutritionists. https://www.bls.gov/ooh/ healthcare/dietitians-andnutritionists.htm. Accessed 4/25/2019.

Centers for Disease Control and Prevention (CDC). Chronic disease prevention and health promotion: Chronic disease prevention system, multiple chronic conditions. www.cdc.gov. Accessed 4/24/2016.

Commission on Dietetic Registration (CDR). CDR-HOD Report. Spring 2013.

Commission on Dietetic Registration (CDR). Home: Registry Statistics as of April 22, 2019. https://www.cdrnet.org/registry-statistics?id=3414\&actionxm=All. Accessed 4/25/2019.

Commission on Dietetic Registration (CDR). Professional development portfolio guide, 2016.

Conklin MT, Simko MD. Direct economic benefits associated with dietetic internships. J Am Diet Assoc. 1994;94:174-178.

Dibert C, Goldenberg D. Preceptors' perceptions of benefits, rewards, supports and commitment to the preceptor role. J Adv Nurs. 1995;21:1144-1151.

Dillman D, Smyth JD, Christian LM. Internet, phone, mail, and mixed-mode surveys. Guidelines for designing web and mobile questionnaires, 2014; 301-349.

Donley Sr. R et al. Graduate clinical nurse preceptors: Implications for improved intraprofessional collaboration. Online J Issues Nurs. 2014 Sept;19(3):1-1.

Escott-Stump S. Nutrition and diagnosis related are. Philadelphia, PA: Wolters Kluwer/Lippincott, 2015.

Gilbride JA, Conklin MT. Benefits of training dietetic students in preprofessional practice programs: A comparison with dietetic internships. J Am Diet Assoc. 1996;96:758-763.

Hall $\mathrm{M}$ et al. To supervise or not to supervise a physical therapist student: A national survey of Canadian physical therapists. J Phys Therapy. 2015; 29(3). 
Hartzler ML, Ballentine JE, Kauflin MJ. Results of a survey to assess residency preceptor development methods and precepting challenges. Am J Health-Syst Pharm. 2015 Aug 1;72.

Hyrkas K, Shoemaker M. Changes in the preceptor role: Re-visiting preceptors' perceptions of benefits, rewards, support and commitment to the role. J Adv Nurs. 2007;60(5):513-524.

Jay AF, Hoffman CJ. Benefits associated with serving as a preceptor for dietetic interns. J Am Diet Assoc. 2000;100(10):1195-1197.

Kruzich LA, Anderson J, Litchfield RE, Wohlsdorf-Arendt S, Oakland MJ. A preceptor focus group approach to evaluation of a dietetic internship. J Am Diet Assoc. $2003 \mathrm{Jul} ; 103(7): 884-886$.

Latessa R, Colvin G, Beaty N, Steiner BD, Pathman DE. Satisfaction, motivation, and future of community preceptors: What are the current trends? (Research Report) Acad Med. 2013;88(8):1164-1170.

Mahan KL, Raymond JL, Escott-Stump S. Krause's food and the nutrition care process, 13th Edition, 2012. St. Louis, MO: Elsevier/Saunders, 2012. Print.

Marincic PZ, Francfort EE. Supervised practice preceptors' perceptions of rewards, benefits, support, and commitment to the preceptor role. J Am Diet Assoc. $2002 ; 102(4)$.

Nasser et al. Dietitians' perceptions of precepting: Knowledge, skills, attitudes, barriers, and training. Can J Diet Pract Res. 2014 Spr;75(1).

Nasser et al. Dietitian preceptor knowledge, skills, attitudes, and training: Key informants perceptions. Can J Diet Pract Res. 2011;72:130.

Natan MV, Qeadan H, Egbaria W. The commitment of Israeli nursing preceptors to the role of preceptor. Nurse Ed Today. 2014;34:1425-1429.

O’Brien A, Giles M, Dempsey S, Lynne S, McGregor M, Kable A, Parmenter G, Parker V. Evaluating the preceptor role for pre-registration nursing and midwifery student clinical education. Nurse Ed Today. 2014;34:19-24.

Ortman B, Arsenault JF. Perceived roles, benefits, and supports for dietetic internship preceptors. Can J Diet Pract Res. 2010 Spr;71(1).

Pallant J. SPSS survival guide. New York: Allen \& Unwin, 2016.

Roofe N, Landry A. Cultivating the desire to mentor in dietetic interns. J Acad Nutr Diet. 2018 Oct;118(10):1817-1825. doi:10.1016/j.jand.2018.01.007 
Singh, A. S., Vik, F. N., Chinapaw, M. J. M., Uijtdewilligen, L., Verloigne, M., Fernández-Alvira, J. M., Stomfai, S., Manios, Y., Martens, M., \& Brug, J. Testretest reliability and construct validity of the ENERGY-child questionnaire on energy balance-related behaviours and their potential determinants: The ENERGY-project. Intl J. Behav Nutr Phys Activity. 2011;8:136. https://doi.org.1186/1479-5868-8-136

Skrabal MZ et al. National survey of volunteer pharmacy preceptors: Effects of region, practice setting, and population density on responses. J Pharm Pract 2010;23(3): 265-272.

Slawson DL, Fitzgerald N, Morgan KT. Position of the Academy of Nutrition and Dietetics: The role of nutrition in health promotion and chronic disease prevention. J Acad Nutr Diet. 2013 Jul;113(7):972-979.

Sodexo. A world of opportunities. http://www.sodexodietitianjobs.com/world-ofopportunities. Accessed 4/24/2015.

Sodexo. Clinical dietitian and nutrition management careers. Accessed 4/24/2015.

Sodexo. Registered dietitian and clinical nutrition management jobs at Sodexo. http://www.sodexodietitianjobs.com/ Accessed 4/24/2015.

Taylor EL, Hasseberg CM, Anderson MA, Knehans AW. Dietetic preceptor educational needs from the preceptor, student, and faculty perspectives. J Allied Health. 2010 Winter;39(4).

U.S. Department of Health and Human Services, Office of Disease Prevention and Health Promotion. Healthy People 2020 Framework. www.healthypeople.gov. Accessed $6 / 25 / 2017$

Usher K, Nolan C, Reser P, Owens J, Tollefson J. An exploration of the preceptor role: preceptors' perception of benefits, rewards, supports and commitment to the preceptor role. J Adv Nurs. 1999;29(2):506-514.

Wilson MA. Dietetic preceptors perceive their role to include a variety of elements. J Am Diet Assoc. 2002;102:968-974.

Winham DM, Wooden AW, Hutchins AM, Morse LM, Shepard CM, Mayol-Kreiser S, Hampl J. Attitudes and perceptions of the dietetic internship preceptor role by Arizona nutrition professionals. Topics in Clin Nutr. 2014;29(3):210-226. 
Appendix A

RD/N Pilot Survey E-mail

\section{Subject: Invitation to all RD/Ns to participate!}

Dear fellow RD/Ns:

All RD/Ns are invited to participate in this online survey that I am conducting for my dissertation related to precepting and the dietetic internship preceptor shortage. This survey will take approximately $\mathbf{1 0}$ minutes to complete. I am looking for responses from RD/Ns that currently precept, are former preceptors or have never precepted. Therefore, all RD/Ns, regardless if you have ever precepted or not, are eligible to participate in this survey and your input is important to us.

My name is Summer Butler and I am a Registered Dietitian Nutritionist at Sodexo and an EdD candidate in Nutrition and Public Health working towards completing the requirements for a doctoral degree at Teachers College, Columbia University, New York, NY. I am asking for your help in gathering data related to the preceptor shortage.

I received your e-mail address from Sodexo to send out this pilot survey secondary to your RD/N position with Sodexo or a related Sodexo account. Participation in this survey is voluntary and you are free to withdraw at any time. Your participation and survey responses will be kept confidential.

If you have any questions or comments regarding your participation in this pilot survey or related to the topic of my dissertation or the survey, please contact me at 201-370-3991 or slb2131@tc.columbia.edu or my advisor Dr Randi Wolf at 212-678-3912.

If you agree you may receive a follow up e-mail to help ensure we have a reliable survey, your participation will be greatly appreciated and further contribute to this national survey and a current hot topic in the field.

Follow this link to the survey:

[link will populate here]

Thank you in advance for your time and participation,

Summer Butler, MA, RD, EdD Candidate in Nutrition and Public Health

Teachers College, Columbia University, New York, NY

201-370-3991 or slb2131@ tc.columbia.edu 
Appendix B

Pilot Survey Consent

Teachers College, Columbia University

525 West $^{120^{\text {th }}}$ Street, New York, NY 10027

\section{RD/N Survey Consent}

This consent will be the first question in the online survey and participant must agree to participate in order for the survey questions to appear.

Your participation in this online survey will take approximately 10 minutes to complete. This survey is being conducted by Summer Butler, MA, RDN, and EdD candidate in Nutrition and Public Health at Teachers College, Columbia University, New York, NY. Her dissertation and research is related to the dietetic internship preceptor shortage and is aimed at understanding more about RD/Ns that have never precepted, currently precept, or are former preceptors. All RD/Ns receiving this survey, regardless of preceptor experience, are invited to participate in this survey.

There is minimal risk, equivalent to completing an online survey, associated with completing this questionnaire. Participation in this survey is voluntary and you are free to withdraw at any time without penalty.

Participation in the survey and your responses will be kept confidential, and electronic information will be password protected. There are no direct benefits to you for participating but responses may help to better inform recommendations and strategies related to recruiting and sustaining preceptors.

If you agree you may receive a follow up e-mail to help ensure we have a reliable survey, your participation will be greatly appreciated.

If you have any questions or comments regarding your participation in this survey or related to the topic of the dissertation or the survey questions, please contact the principal investigator (Summer Butler 201-370-3991, slb2131 @tc.columbia.edu) or the research advisor (Dr. Randi Wolf 212-678-3912). If you have any comments, questions or concerns regarding the conduct of the research or your rights as a participant, please contact Teachers College, Columbia University Institutional Review Board/IRB at 212$678-4105$.

If you are 18 years of age or older, understand the information provided, and consent to participate in this study, please choose 'I agree' below to begin the survey.

\section{O I agree O I do not agree}

Thank you in advance for your time and participation! 


\section{Appendix C \\ RD/N Pilot Survey Reminder E-mail}

\section{Subject: Invitation to all RD/Ns to participate!}

This is a reminder e-mail, if you have already completed this online survey please disregard.

Dear fellow RD/Ns:

All RD/Ns are invited to participate in this online survey that I am conducting for my dissertation related to precepting and the dietetic internship preceptor shortage. This survey will take approximately $\mathbf{1 0}$ minutes to complete. I am looking for responses from RD/Ns that currently precept, are former preceptors or have never precepted. Therefore, all RD/Ns, regardless if you have ever precepted or not, are eligible to participate in this survey and your input is important to us.

My name is Summer Butler and I am a Registered Dietitian Nutritionist at Sodexo and an EdD candidate in Nutrition and Public Health working towards completing the requirements for a doctoral degree at Teachers College, Columbia University, New York, NY. I am asking for your help in gathering data related to the preceptor shortage.

I received your e-mail address from Sodexo to send out this pilot survey secondary to your RD/N position with Sodexo or a related Sodexo account. Participation in this survey is voluntary and you are free to withdraw at any time. Your participation and survey responses will be kept confidential.

If you have any questions or comments regarding your participation in this pilot survey or related to the topic of my dissertation or the survey, please contact me at 201-370-3991 or slb2131@tc.columbia.edu or my advisor Dr Randi Wolf at 212-678-3912.

If you agree you may receive a follow up e-mail to help ensure we have a reliable survey, your participation will be greatly appreciated and further contribute to this national survey and a current hot topic in the field.

Follow this link to the survey:

[link will populate here]

Thank you in advance for your time and participation,

Summer Butler, MA, RD, EdD Candidate in Nutrition and Public Health

Teachers College, Columbia University, New York, NY

201-370-3991 or slb2131@ tc.columbia.edu 


\section{Appendix D}

\section{RD/N Retest Pilot Survey E-mail}

Subject: You completed a survey recently, need your help testing reliability

Dear fellow RD/Ns:

You recently completed an online $\mathrm{RD} / \mathrm{N}$ survey. In order to test the reliability of the survey I am requesting your assistance. Participation includes retaking the online survey, which will take approximately $\mathbf{1 0}$ minutes to complete. Your participation is greatly appreciated and will assist us in gathering data related to the preceptor shortage. All RD/Ns, whether you have ever precepted or not, are eligible to participate and your input is important to us.

As a reminder: My name is Summer Butler and I am a Registered Dietitian Nutritionist at Sodexo and an EdD candidate in Nutrition and Public Health working towards completing the requirements for a doctoral degree at Teachers College, Columbia University, New York, NY.

I received your e-mail address from Sodexo to send out this pilot survey secondary to your RD/N position with Sodexo or a related Sodexo account. Participation in this survey is voluntary and you are free to withdraw at any time. Your participation and survey responses will be kept confidential.

If you have any questions or comments regarding your participation in this pilot survey or related to the topic of my dissertation or the survey, please contact me at 201-370-3991 or slb2131@tc.columbia.edu or my advisor Dr Randi Wolf at 212-678-3912.

Follow this link to the survey:

[link will populate here]

Thank you in advance for your time and participation,

Summer Butler, MA, RD, EdD Candidate in Nutrition and Public Health

Teachers College, Columbia University, New York, NY

201-370-3991 or slb2131@tc.columbia.edu 
Appendix E

RD/N Retest Pilot Survey Reminder E-mail

Subject: You completed a survey recently, need your help testing reliability

This is a reminder e-mail, only if you have already completed the survey a second time please disregard.

Dear fellow RD/Ns:

You recently completed an online RD/N survey. In order to test the reliability of the survey I am requesting your assistance. Participation includes retaking the online survey, which will take approximately 10 minutes to complete. Your participation is greatly appreciated and will assist us in gathering data related to the preceptor shortage. All RD/Ns, whether you have ever precepted or not, are eligible to participate and your input is important to us.

As a reminder: My name is Summer Butler and I am a Registered Dietitian Nutritionist at Sodexo and an EdD candidate in Nutrition and Public Health working towards completing the requirements for a doctoral degree at Teachers College, Columbia University, New York, NY.

I received your e-mail address from Sodexo to send out this pilot survey secondary to your RD/N position with Sodexo or a related Sodexo account. Participation in this survey is voluntary and you are free to withdraw at any time. Your participation and survey responses will be kept confidential.

If you have any questions or comments regarding your participation in this pilot survey or related to the topic of my dissertation or the survey, please contact me at 201-370-3991 or slb2131@tc.columbia.edu or my advisor Dr Randi Wolf at 212-678-3912.

Follow this link to the survey:

[link will populate here]

Thank you in advance for your time and participation,

Summer Butler, MA, RD, EdD Candidate in Nutrition and Public Health

Teachers College, Columbia University, New York, NY

201-370-3991 or slb2131@tc.columbia.edu 


\section{Appendix F}

\section{RD/N Pilot Survey}

\section{RD/N Survey}

Please note the online survey was more user friendly and visually appealing (this is the exported word version), and question (Q) numbers will not appear online due to skip patterns. Depending on preceptor status will depend on the questions participants will see, each set of questions for those participants are titled in this document.

\section{Teachers College, Columbia University}

Testing RD/N Survey, your responses and feedback are appreciated.

\section{Questions for ALL participants:}

Important to Note: if you have a mobile/cell phone survey option also showing up on your screen and you are not using a cell phone to take the survey, please click on the small mobile icon picture above the cell phone survey view to hide it (statement will only be included if this issue remains).

Q1

Consent will be here - see attached.

If you are 18 years of age or older, understand the information provided, and freely consent to participate in this study, please choose 'I agree' below to begin the survey.

I agree

I do not agree (ends survey)

Q2 Are you a Registered Dietitian (RD)/Registered Dietitian Nutritionist (RDN)?

Yes

No (ends survey)

Q3 Are you currently working in the field of nutrition/dietetics?

Yes

No, out of the field for under 1 year

No, out of the field for 1 year or more

Q4 What is your preceptor status?

Current preceptor (or have precepted within the past year) for a US accredited Dietetic Internship program

Former preceptor of a US accredited Dietetic Internship program (greater than $1 \mathrm{yr}$ ago) Never precepted for a US accredited Dietetic Internship program 


\section{Appendix F1 - RD/N Pilot Survey - Current Preceptor Specific Questions}

Q5 In your current position, serving as a preceptor is: Choose the best answer.

Required

Allowed but not required

Not allowed or against policy

Do not know

Other:

Q6 I usually precept during the dietetic intern's rotation: Choose the ONE rotation you primarily precept during and please respond to the rest of the questions in this survey accordingly.

Medical Nutrition Therapy (inpatient)

Medical Nutrition Therapy (outpatient)

Community Nutrition

Food Service Management

Research

Specialty (i.e. eating disorders, transplant, etc):

Other:

Q7 You responded that you primarily precept during the intern's Medical Nutrition Therapy (inpatient) rotation, please specify where you primarily precept: Only if you precept equally in more than 1 area, choose those that apply, otherwise only choose the 1 where you primarily precept.

Hospital (acute care)

Nursing Home (long term care) or Transitional Care

Rehabilitation

Other:

Q8 When you have a dietetic intern, how many hours a week is each intern under your supervision? If the hours vary, provide average number of hours per intern per week during rotation.

Q9 Are there other RDs/RDNs regularly scheduled to precept the intern during the same rotation at your facility?

Yes

No

Q10 Are you the primary preceptor for the dietetic intern's rotation? (i.e. signing off on evaluations, hours, etc. that are returned to the internship program)

Yes, always

Yes, Sometimes

No 


\section{I am not sure}

Q11 How many hours per week, during a typical week with an intern, would you say you do each of the following. Enter the number of hours per week in all boxes that apply. Please round to the nearest half hour (i.e. 0.5).

The total line is just to help you gauge your answers and is not expected to equal total hours per week you are with the intern.

Assessing student learning, providing feedback, evaluating student learning

Teaching the dietetic intern

Reviewing or researching topics related to the rotation or intern's questions (i.e. updated evidence-based guidelines, standards of care, nutrition care process terminology)

Assisting intern with internship work (i.e. projects, case studies)

Communication issues (i.e. managing conflict, negotiating solutions)

Q245 How many hours per rotation on average do you spend in each area below. Enter the number of hours per rotation in all boxes that apply. Please round to the nearest hour (i.e. 1). The total line is just to help you gauge your answers.

Planning and organizing supervised practice experience (includes prior to start of intern and during rotation)

Orienting and training of intern

Q246 Please consider each statement with reference to your experience as a preceptor. Using the scale below, please choose the response which best describes your response to the statement. As a preceptor I have the opportunity to...

\begin{tabular}{|l|l|l|l|l|}
\hline & $\begin{array}{c}\text { Strongly } \\
\text { Disagree }\end{array}$ & Disagree & Agree & $\begin{array}{c}\text { Strongly } \\
\text { Agree }\end{array}$ \\
\hline Learn from dietetic interns & & & & \\
\hline $\begin{array}{l}\text { Keep current and remain stimulated in my } \\
\text { profession }\end{array}$ & & & & \\
\hline Increase my own professional knowledge base & & & & \\
\hline Improve my teaching skills & & & & \\
\hline Improve my organizational skills & & & & \\
\hline Improve my leadership skills & & & & \\
\hline
\end{tabular}


Q247 Please consider each statement with reference to your experience as a dietetic internship preceptor. Using the scale below, please choose the response which best describes your response to the statement.

\begin{tabular}{|l|l|l|l|l|l|}
\hline $\begin{array}{l}\text { My goals as a preceptor are clearly } \\
\text { defined }\end{array}$ & $\begin{array}{c}\text { Strongly } \\
\text { Disagree }\end{array}$ & Disagree & Agree & $\begin{array}{c}\text { Strongly } \\
\text { Agree }\end{array}$ & $\begin{array}{c}\text { Not } \\
\text { Applicable }\end{array}$ \\
\hline $\begin{array}{l}\text { I feel I have had adequate preparation } \\
\text { for my role as preceptor }\end{array}$ & & & & & \\
\hline $\begin{array}{l}\text { Support is available to help me develop } \\
\text { in my role as a preceptor }\end{array}$ & & & & & \\
\hline $\begin{array}{l}\text { My workload is appropriate when I } \\
\text { function as a preceptor }\end{array}$ & & & & & \\
\hline $\begin{array}{l}\text { My co-workers are supportive when I } \\
\text { function as a preceptor }\end{array}$ & & & & & \\
\hline $\begin{array}{l}\text { Management/administration are } \\
\text { supportive when I function as a } \\
\text { preceptor }\end{array}$ & & & & & \\
\hline
\end{tabular}

Q248 Please consider each statement with reference to your experience as a preceptor. Using the scale below, please choose the response which best describes your response to the statement.

\begin{tabular}{|l|l|l|l|l|}
\hline $\begin{array}{l}\text { Being a preceptor really inspires me to perform my } \\
\text { very best }\end{array}$ & $\begin{array}{c}\text { Strongly } \\
\text { Disagree }\end{array}$ & Disagree & Agree & $\begin{array}{c}\text { Strongly } \\
\text { Agree }\end{array}$ \\
\hline $\begin{array}{l}\text { I find that my values and the values of the internship } \\
\text { program are very similar }\end{array}$ & & & & \\
\hline $\begin{array}{l}\text { I really care about the fate of the internship } \\
\text { program(s) }\end{array}$ & & & & \\
\hline $\begin{array}{l}\text { Deciding to be a preceptor was a definite mistake on } \\
\text { my part }\end{array}$ & & & & \\
\hline $\begin{array}{l}\text { It would take very little change in my present } \\
\text { circumstances to cause me to stop being a preceptor }\end{array}$ & & & & \\
\hline I feel very little loyalty to the internship program(s) & & & & \\
\hline $\begin{array}{l}\text { There is not too much to be gained by continuing to } \\
\text { be a preceptor }\end{array}$ & & & & \\
\hline I am proud to tell others that I am a preceptor & & & & \\
\hline $\begin{array}{l}\text { I am willing to put in a great deal of effort beyond } \\
\text { what is normally expected in order to help the intern } \\
\text { be successful }\end{array}$ & & & & \\
\hline
\end{tabular}


I am enthusiastic about the internship program(s)

when I talk to my colleagues

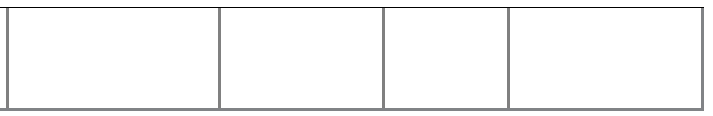

Q12 In the past year have you RECEIVED any of the following for precepting? Check ALL that apply.

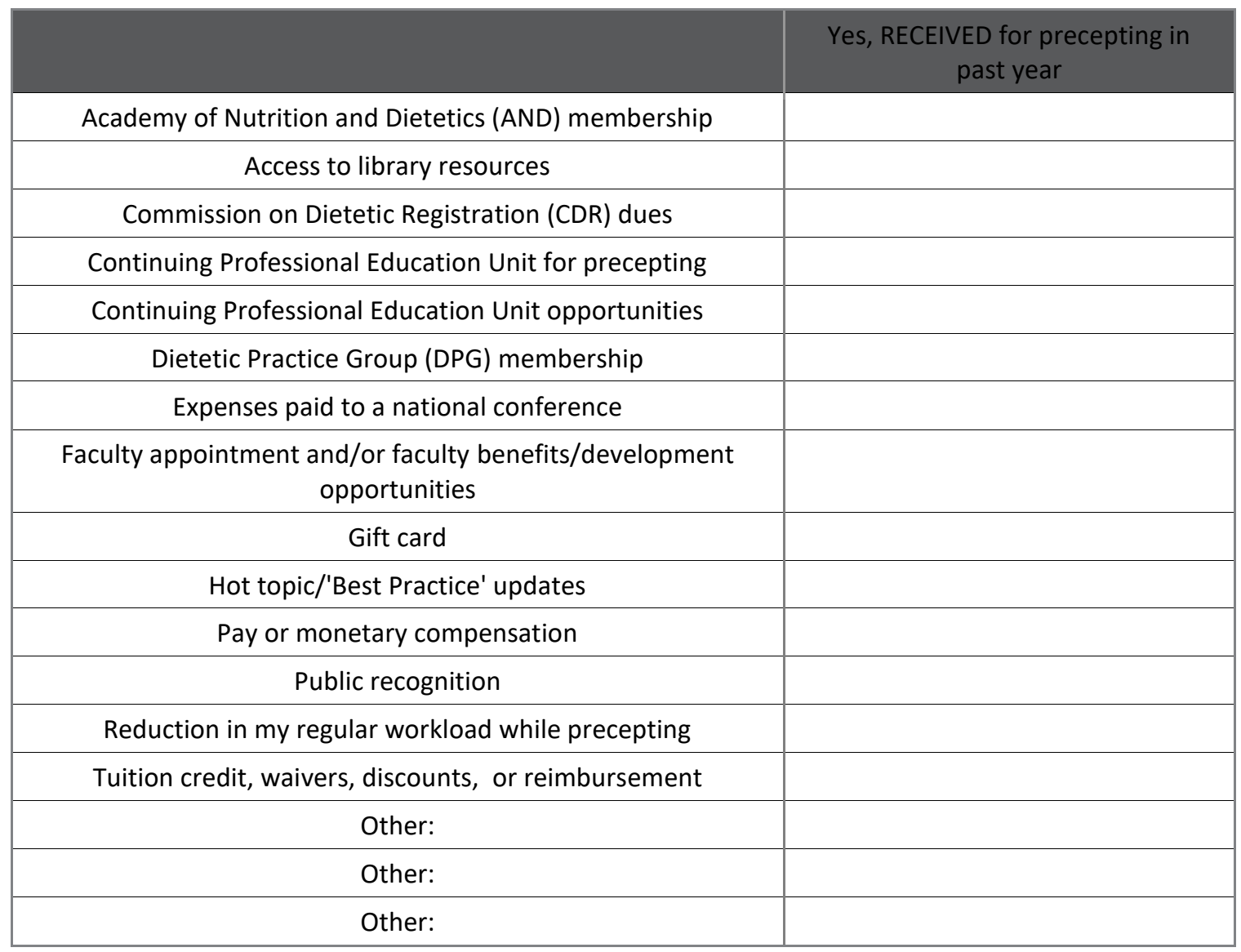

Q266 Which of the following, if offered to you, would encourage you to precept? Choose and rank your top 5. Click and hold (or touch) and move the motivating item on the left into the box on the right. Abbreviations: AND=Academy of Nutrition and Dietetics CDR=Commission on Dietetics Registration CPEU=Continuing Professional Education Units

After reviewing the full list RANK YOUR TOP FIVE choices ( $1=1$ st choice, $2=2$ nd choice and so on).
Answers can be moved around while organizing your thoughts, there are also options for other.
AND membership fee paid
Access to library resources
CDR annual membership paid
CPEUs received for precepting
CPEU opportunities




\begin{tabular}{|l|}
\hline Dietetic Practice Group membership fee paid \\
\hline Expenses paid to attend a national conference \\
\hline Faculty appointment and/or faculty benefits/development opportunities \\
\hline Gift card \\
\hline Hot topic/'Best Practice' updates \\
\hline Pay or monetary compensation \\
\hline Public recognition \\
\hline Reduction in my regular workload \\
\hline Tuition credit, waivers, discounts, or reimbursement \\
\hline
\end{tabular}

Q13 What would motivate you to continue precepting, that we haven't already covered? (include if there is anything internship directors or students could do to change your mind)

Q237 For some people, the factors listed below are barriers to precepting. Are these BARRIERS to you? Check ALL that apply.

experience with internship program or a previous intern

computer or technology related issues

lack interest in precepting

lack of appreciation/recognition

lack of compensation

lack of support when precepting

lack of preceptor training

length of rotation

legal issues (i.e. internship contracts or agreements) and/or liability concerns

my health and/or family/personal obligations

my lack of knowledge/skills or experience

not enough for interns to do at my workplace

obtaining internship contract/agreement

quality of the intern(s) and/or program(s)

restricted by facility or management

short staffed or down-sizing

stress

technology or electronic medical record related

time consuming

unable to demonstrate added value of having interns

unfamiliar with the internship program

workload

workspace limitations

Other:

Q15 Are there any other barriers to you precepting that we haven't already covered? 
Q16 In your current position, the final decision to precept, or not to precept, is made by: Check ALL that apply.

Owner, CEO, Senior Staff or Administration

Director, General Manager, or Coordinator

Nutrition Manager, Supervisor, or Chief RD/RDN

Food Service Manager or Supervisor

Human Resources

Other:

Do not know

Not applicable

Q17 In your current position, what is your involvement in the final decision to precept, or not to precept? (choose the best response)

I make the final decision

I am involved in making the final decision

I am not involved in making the final decision

Not applicable

Q18 In your most recent position, if you were in agreement, would you be allowed to precept more than one intern at the same time?

Definitely not

Probably not

Probably yes

Definitely yes

I do not know

Q19 Why did you FIRST become a preceptor? (choose ALL that apply)

Relationship with Dietetic Internship Director

Required by workplace

It is my professional responsibility

Interns create positive change for the department/organization

To contribute to the future of the profession

To give back to the program or field

To learn from the intern/keep up-to-date

To network/stay connected

To screen potential employees or job recruit

To teach, mentor and/or introduce students/interns to the field

For the tangible benefits (i.e. tuition credit, continuing education units, monetary compensation, etc)

Other:

Do not remember 
Q260 When you were a dietetic intern, how satisfied were you with your preceptor experiences?

\begin{tabular}{|c|c|c|c|c|c|c|}
\hline & $\begin{array}{c}\text { Very } \\
\text { Dissatisfied }\end{array}$ & Dissatisfied & Neutral & Satisfied & $\begin{array}{c}\text { Very } \\
\text { Satisfied }\end{array}$ & $\begin{array}{c}\text { Not } \\
\text { Applicable }\end{array}$ \\
\hline $\begin{array}{c}\text { Satisfaction with } \\
\text { your preceptors }\end{array}$ & & & & & & \\
\hline
\end{tabular}

Q20 Why do you CONTINUE to precept? (choose ALL that apply)

Relationship with Dietetic Internship Director

Required by workplace

It is my professional responsibility

Interns create positive change for the department/organization

Tangible benefits (i.e. tuition credit, continuing education units, monetary compensation, etc)

To contribute to the future of the profession

To give back to the program or field

To learn from the intern/keep up-to-date

To network/stay connected

To screen potential employees or job recruit

To teach, mentor and/or introduce students/interns to the field

Other:

I am not sure

Q21 Have you completed preceptor training? Choose ALL that may apply.

Yes, CDR's Free Online Preceptor Training

Yes, formal training (i.e. class, online course)

Yes, informal training (i.e. packet/handbook)

No (never received/completed training)

Do not remember

Q22 How often do you feel supported by the Dietetic Internship (DI) program(s) for which you precept? Choose the best answer in each row. (i.e. communication with Director and/or other preceptors, availability of Director/Faculty, preceptor resources/references, trainings, etc.)

\begin{tabular}{|l|l|l|l|l|l|l|} 
& Never & Rarely & Sometimes & $\begin{array}{c}\text { Most of the } \\
\text { Time }\end{array}$ & Always & N/A \\
\hline College/University DI Program & & & & & & \\
\hline $\begin{array}{l}\text { Company Based DI Program (i.e. } \\
\text { Sodexo, Aramark, etc) }\end{array}$ & & & & & & \\
\hline Hospital Based DI Program & & & & & & \\
\hline Other: & & & & & & \\
\hline
\end{tabular}


Q23 If you have a personal preference for working with interns from a particular type of Dietetic Internship program(s), please indicate below. Choose ALL that apply.

No preference

College/University based

Company based (i.e. Sodexo, Aramark, etc.)

Hospital based

Other:

Any additional Comment(s):

Q24 If it was solely your decision, would you continue taking interns?

Yes

Maybe (include reason):

No (include reason):

Q25 Years you have served as a dietetic internship preceptor in the US: Please round to nearest year (i.e. 1).

Q26 Usual number of interns precept in 1 year?

Q27 How many dietetic internship programs have you precepted interns from in the last year?(for example, Teachers College and Sodexo $=2$ )

Q28 Do you have more than 1 intern at the same time?

Always

Usually

Sometimes

Rarely

Never

Q29 Average number of weeks 1 intern rotates with you over the course of their internship:

Q30 What is your primary practice area?

Academia (or college/university faculty)

Business \& Industry

Communication/Publication

Community/Public Health

Consultation and Private Practice

Culinary

Food Service

Government or State Agency

Health Care

School Nutrition

Wellness

Other: 
Q31 Thank you for continuing, your responses are important and your time is appreciated!

Q32 Years working in field of nutrition/dietetics:

Q33 Years working in current, or most recent, position:

Q34 In what state do you currently work? If not working, in which state do you reside? (select one)

Please select a state from this list

I do not reside in the United States

Q229 How would you describe the area where you work? (select one) If not working, please refer to the area in which you live.

Urban (i.e. densely populated, city)

Suburban

Rural

Other:

Q35 Highest degree completed in nutrition/dietetics related field:

Bachelors

Masters

Doctorate

Q36 Additional specialization credentials hold (check all that apply):

Board Certified Specialist in Pediatric Nutrition (CSP)

Board Certified Specialist in Gerontological Nutrition (CSG)

Board Certified Specialist in Oncology Nutrition

Board Certified Specialist in Renal Nutrition (CSR)

Board Certified Specialist in Sports Nutrition (CSSD)

Certified Diabetes Educator (CDE)

Certified Nutrition Support Clinician (CNSC)

Other(s):

Not Applicable

Q242 Are you teaching outside of the preceptor role?

Yes

No 
Q253 You responded yes to teaching outside of the preceptor role, please indicate in what capacity you are teaching? Choose all that apply.

Dietetic Internship Program

University/College

Hospital/Medical Center

Other

Q38 Have you held a professional leadership position? (leadership position could be held in any setting, such as schools, food service institutions, clinical settings, corporations, etc. and includes administration/management/supervisor positions, elected position, etc.)

Yes, currently hold a leadership position

Yes, previously held a leadership position

No, never

Q39 Are you an Academy of Nutrition and Dietetics (AND) member?

Yes

Former Member

Never

Q40 Are you a member of the Nutrition and Dietetic Educators and Preceptors (NDEP) Dietetic Practice Group (DPG) of AND?

Yes

Former Member

Never

Q41 What is your age in years?

Q42 What gender do you identify yourself as?

Female

Male

Transgender or Other

Q43 What ethnicity/race do you identify yourself as?

American Indian or Alaskan Native

Asian or Pacific Islander

Black (not of Hispanic origin)

Hispanic

White (not of Hispanic origin)

Other ethnicity/race (specify): 
Q258 If you have additional comments related to precepting or any of the questions in this survey please include here:

Are you willing to be contacted in the next 3 weeks to test reliability of this survey?

Yes

No

Q44 If you have additional comments you wish to discuss further, include your preferred contact information below or please e-mail slb2131@tc.columbia.edu or call 201-370-3991.

Phone:

E-mail:

Other:

Q45 Browser Meta Info

Browser

Version

Operating System

Screen Resolution

Flash Version

Java Support

User Agent

\section{END OF QUESTIONS FOR CURRENT PRECEPTORS}


Appendix F2 - RD/N Pilot Survey - Never Precepted Specific Questions

Q46 Are you eligible to precept for a US accredited Dietetic Internship program?

Yes, eligible to precept

Do not know if eligible to precept

No, not eligible to precept

Q47 Have you ever been asked to serve as a preceptor for a US accredited (i.e., accredited by CADE/ACEND) Dietetic Internship program?

Yes

Not sure

No

Q48 If you were able and willing to precept, do you know how to sign up to start precepting?

Yes

No

Q236 For some people, the factors listed below are barriers to precepting. Are these BARRIERS to you? Check ALL that apply.

experience with internship program or a previous intern

computer or technology related issues

lack interest in precepting

lack of appreciation/recognition

lack of compensation

lack of support when precepting

lack of preceptor training

length of rotation

legal issues (i.e. internship contracts or agreements) and/or liability concerns

my health and/or family/personal obligations

my lack of knowledge/skills or experience

not enough for interns to do at my workplace

obtaining internship contract/agreement

quality of the intern(s) and/or program(s)

restricted by facility or management

short staffed or down-sizing

stress

technology or electronic medical record related

time consuming

unable to demonstrate added value of having interns

unfamiliar with the internship program

workload

workspace limitations

Other: 
Q51 Are there any other barriers, or reasons you do not precept, that we haven't already covered?

Q52 Which of the following, if offered to you, would encourage you to precept? Choose and rank your top 5. Click and hold (or touch) and move the motivating item on the left into the

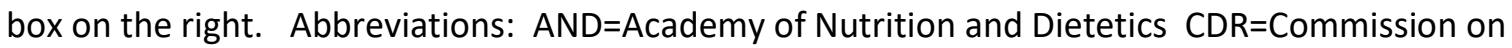
Dietetics Registration CPEU=Continuing Professional Education Units

\begin{tabular}{l} 
After reviewing the full list RANK YOUR TOP FIVE choices ( $1=1$ st choice, $2=2$ nd choice and so on). \\
Answers can be moved around while organizing your thoughts, there are also options for other. \\
\hline AND membership fee paid \\
\hline Access to library resources \\
\hline CDR annual membership paid \\
\hline CPEUs received for precepting \\
\hline CPEU opportunities \\
\hline Dietetic Practice Group membership fee paid \\
\hline Expenses paid to attend a national conference \\
\hline Faculty appointment and/or faculty benefits/development opportunities \\
\hline Gift card \\
\hline Hot topic/'Best Practice' updates \\
\hline Pay or monetary compensation \\
\hline Public recognition \\
\hline Reduction in my regular workload \\
\hline Tuition credit, waivers, discounts, or reimbursement \\
\hline Other:
\end{tabular}

Q53 Please add your thoughts or any issues you may have had responding to the previous question which asked you to rank your top 5 incentives?

Q54 What benefits would motivate you to start precepting that we haven't already covered?

Q55 In your current position, the final decision to precept, or not to precept, is made by: Check ALL that apply.

Owner, CEO, Senior Staff or Administration

Director, General Manager, or Coordinator

Nutrition Manager, Supervisor, or Chief RD/RDN

Food Service Manager or Supervisor

Human Resources

Other:

Do not know

Not applicable 
Q239 In your current position, what is your involvement in the final decision to precept, or not to precept? (choose the best response)

I make the final decision

I am involved in making the final decision

I am not involved in making the final decision

Not applicable

Q57 Please indicate how strongly you agree or disagree with the following statements related to precepting a dietetic intern.

\begin{tabular}{|l|l|l|l|l|l|}
\hline & $\begin{array}{c}\text { Strongly } \\
\text { Disagree }\end{array}$ & Disagree & $\begin{array}{c}\text { Neither } \\
\text { Agree nor } \\
\text { Disagree }\end{array}$ & Agree & $\begin{array}{c}\text { Strongly } \\
\text { Agree }\end{array}$ \\
\hline $\begin{array}{l}\text { I would be an effective preceptor. } \\
\text { a dietetic intern. }\end{array}$ & & & & & \\
\hline $\begin{array}{l}\text { I am confident I have the knowledge } \\
\text { and skills to precept. }\end{array}$ & & & & & \\
\hline $\begin{array}{l}\text { I would be more likely to precept if I had } \\
\text { access to an On-Call specialist. i.e. to } \\
\text { answer questions related to my area of } \\
\text { practice while precepting }\end{array}$ & & & & & \\
\hline
\end{tabular}

Q263 When you were a dietetic intern, how satisfied were you with your preceptor experiences?

\begin{tabular}{|l|l|l|l|l|l|l|}
\hline & $\begin{array}{c}\text { Very } \\
\text { Dissatisfied }\end{array}$ & Dissatisfied & Neutral & Satisfied & $\begin{array}{c}\text { Very } \\
\text { Satisfied }\end{array}$ & $\begin{array}{c}\text { Not } \\
\text { Applicable }\end{array}$ \\
\hline $\begin{array}{l}\text { Satisfaction with } \\
\text { your preceptors }\end{array}$ & & & & & & \\
\hline
\end{tabular}

Q58 If it was solely your decision, would you take interns?

Yes

Maybe (include reason):

No (include reason):

Q59 What is (or was) your primary practice area?

Academia (or college/university faculty)

Business \& Industry

Communication/Publication

Community/Public Health

Consultation and Private Practice

Culinary 
Food Service

Government or State Agency

Health Care

School Nutrition

Wellness

Other:

Q60 Thank you for continuing, your responses are important and your time is appreciated!

Q61 Years working in field of nutrition/dietetics:

Q62 Years working in current, or most recent, position:

Q235 In what state do you currently work? If not working, in which state do you reside? (select one)

Please select a state from this list

I do not reside in the United States

Q227 How would you describe the area where you work? (select one)If not working, please refer to the area in which you live.

Urban (i.e. densely populated, city)

Suburban

Rural

Other:

Q64 Highest degree completed in nutrition/dietetics related field:

Bachelors

Masters

Doctorate

Q65 Additional specialization credentials hold (check all that apply):

Board Certified Specialist in Pediatric Nutrition (CSP)

Board Certified Specialist in Gerontological Nutrition (CSG)

Board Certified Specialist in Oncology Nutrition

Board Certified Specialist in Renal Nutrition (CSR)

Board Certified Specialist in Sports Nutrition (CSSD)

Certified Diabetes Educator (CDE)

Certified Nutrition Support Clinician (CNSC)

Other(s)

Not Applicable

Q251 Are you teaching outside of the preceptor role? 
Yes

No

Q250 You responded yes to teaching outside of the preceptor role, please indicate in what capacity you are teaching? Choose all that apply.

Dietetic Internship Program

University/College

Hospital/Medical Center

Other

Q67 Have you held a professional leadership position? (leadership position could be held in any setting, such as schools, food service institutions, clinical settings, corporations, etc. and includes administration/management/supervisor positions, elected position, etc.)

Yes, currently hold a leadership position

Yes, previously held a leadership position

No, never

Q68 Are you an Academy of Nutrition and Dietetics (AND) member?

Yes

Former Member

Never

Q69 Are you a member of the Nutrition and Dietetic Educators and Preceptors (NDEP) Dietetic Practice Group (DPG) of AND?

Yes

Former Member

Never

Q70 What is your age in years?

Q71 What gender do you identify yourself as?

Female

Male

Transgender or Other

Q72 What ethnicity/race do you identify yourself as?

American Indian or Alaskan Native

Asian or Pacific Islander

Black (not of Hispanic origin)

Hispanic

White (not of Hispanic origin)

Other ethnicity/race (specify): 
Q257 If you have additional comments related to precepting or any of the questions in this survey please include here:

Are you willing to be contacted in the next 3 weeks to test reliability of this survey?

Yes

No

Q73 If you have additional comments you wish to discuss further, include your preferred contact information below or please e-mail slb2131@tc.columbia.edu or call 201-370-3991.

Phone:

E-mail:

Other:

Q74 Browser Meta Info

Browser

Version

Operating System

Screen Resolution

Flash Version

Java Support

User Agent

\section{END OF QUESTIONS FOR NEVER PRECEPTED}




\section{Appendix F3 - RD/N Pilot Survey - Former Preceptor Specific Questions}

Q75 In your most recent position, serving as a preceptor was: Choose the best answer.

Required

Allowed but not required

Not allowed or against policy

Do not know

Other

Q76 I usually precepted during the dietetic intern's rotation: Choose the rotation you primarily precepted during and please respond to the rest of the questions in this survey accordingly.

Medical Nutrition Therapy (inpatient)

Medical Nutrition Therapy (outpatient)

Community Nutrition

Food Service Management

Research

Specialty (i.e. eating disorders, transplant, etc)

Other:

Q77 You responded that you primarily precepted during the intern's Medical Nutrition Therapy (inpatient) rotation, please specify where you primarily precepted: Only if you precepted equally in more than 1 area, choose those that apply, otherwise only choose the 1 where you primarily precepted.

Hospital (acute care)

Nursing Home (long term care) or Transitional Care

Rehabilitation

Other:

Q78 When you have had an intern, how many hours a week was the intern under your supervision?

Q79 Were you the primary preceptor for the dietetic intern's rotation? (i.e. signing off on evaluations, hours, etc. that are returned to the internship program)

Yes, always

Yes, sometimes

No

I am not sure 
Q80 Which of the following benefits, if offered to you, would motivate you to precept? (Check ALL that apply)

\begin{tabular}{|l|l|}
\hline & $\begin{array}{c}\text { If offered for precepting, would motivate } \\
\text { me to precept }\end{array}$ \\
\hline Academy of Nutrition and Dietetics (AND) membership & \\
\hline Access to library resources & \\
\hline Commission on Dietetic Registration (CDR) dues & \\
\hline Continuing Professional Education Units for precepting & \\
\hline Continuing Professional Education Unit Opportunities & \\
\hline Dietetic Practice Group (DPG) membership & \\
\hline Expenses paid to a national conference & \\
\hline $\begin{array}{l}\text { Faculty appointment and/or faculty } \\
\text { benefits/development opportunities }\end{array}$ & \\
\hline Gift card & \\
\hline Hot topic/'Best Practice' updates & \\
\hline Pay or monetary compensation & \\
\hline Public recognition & \\
\hline Reduction in my regular workload while precepting & \\
\hline Tuition credit, waivers, discounts, or reimbursement & \\
\hline Other: & \\
\hline Other: & \\
\hline Other: & \\
\hline
\end{tabular}

Q265 Which of the following, if offered to you, would encourage you to precept? Choose and rank your top 5. Click and hold (or touch) and move the motivating item on the left into the box on the right. Abbreviations:

AND=Academy of Nutrition and Dietetics $C D R=$ Commission on Dietetics Registration CPEU=Continuing Professional Education Units

\begin{tabular}{l} 
After reviewing the full list RANK YOUR TOP FIVE choices ( $1=1$ st choice, $2=2$ nd choice and so on). \\
Answers can be moved around while organizing your thoughts, there are also options for other. \\
AND membership fee paid \\
\hline Access to library resources \\
\hline CDR annual membership paid \\
CPEUs received for precepting \\
\hline CPEU opportunities \\
Dietetic Practice Group membership fee paid \\
Expenses paid to attend a national conference
\end{tabular}




\begin{tabular}{|l|}
\hline Faculty appointment and/or faculty benefits/development opportunities \\
\hline Gift card \\
\hline Hot topic/'Best Practice' updates \\
\hline Pay or monetary compensation \\
\hline Public recognition \\
\hline Reduction in my regular workload \\
\hline Tuition credit, waivers, discounts, or reimbursement \\
\hline
\end{tabular}

Q82 Please include any issues with or comments on previous question asking you to rank top 5 incentives.

Q83 Reasons I stopped taking interns:Check ALL that apply.

Change in management

Changed jobs/positions

Company lost account or contract

Instructed by Director/Manager/Supervisor/Coordinator

Instructed by Human Resources

Instructed by Owner, CEO, or Senior Staff/Administration

Merger

No contract or contract issues with the internship

Not working or on leave of absence

Other internship responsibilities, already scheduled to precept interns from another program

Personal circumstances

Program affiliation change

Short staffed

Stress

Technology or electronic medical record (EMR) related

Too much paperwork

Unable to demonstrate added value of precepting interns

Workload

Workspace

Other(s)

Q84 What would motivate you to precept that we haven't already covered? (include if there is anything internship directors or students/interns could do to help change your mind)

Q85 How often did you feel supported by the Dietetic Internship (DI) program(s) for which you precepted? Choose the best answer in each row. (i.e. communication with Director and/or other preceptors, availability of Director/Faculty, preceptor resources/references, trainings, etc.) 


\begin{tabular}{|l|l|l|l|l|l|l|} 
& Never & Rarely & Sometimes & $\begin{array}{c}\text { Most of the } \\
\text { Time }\end{array}$ & Always & N/A \\
\hline College/University DI Program & & & & & & \\
\hline $\begin{array}{l}\text { Company Based DI Program (i.e. } \\
\text { Sodexo, Aramark, etc) }\end{array}$ & & & & & & \\
\hline Hospital Based DI Program & & & & & & \\
\hline Other: & & & & & & \\
\hline
\end{tabular}

Q86 For some people, these factors are barriers to precepting. Are these BARRIERS to you? Check ALL that apply.

experience with internship program or a previous intern computer or technology related issues

Llack interest in precepting lack of appreciation/recognition lack of compensation lack of support when precepting lack of preceptor training length of rotation legal issues (i.e. internship contracts or agreements) and/or liability concerns my health and/or family/personal obligations my lack of knowledge/skills or experience not enough for interns to do at my workplace obtaining internship contract/agreement quality of the intern(s) and/or program(s) restricted by facility or management short staffed or down-sizing stress technology or electronic medical record related time consuming unable to demonstrate added value of having interns unfamiliar with the internship program workload workspace limitations Other:

Q87 Are there any other barriers to you precepting that we haven't already covered?

Q88 In your current position, the final decision to precept, or not to precept, is made by: Check ALL that apply.

Owner, CEO, Senior Staff or Administration Director, General Manager, or Coordinator Nutrition Manager, Supervisor, or Chief RD/RDN Food Service Manager or Supervisor 


\section{Human Resources}

Other:

Do not know

Not applicable

Q238 In your current position, what is your involvement in the final decision to precept, or not to precept? (choose the best response)

I make the final decision

I am involved in making the final decision

I am not involved in making the final decision

Not applicable

Q90 Please indicate how strongly you agree or disagree with the following statements related to precepting a dietetic intern.

\begin{tabular}{|l|l|l|l|l|l|}
\hline & $\begin{array}{c}\text { Strongly } \\
\text { Disagree }\end{array}$ & Disagree & $\begin{array}{c}\text { Neither } \\
\text { Agree nor } \\
\text { Disagree }\end{array}$ & $\begin{array}{c}\text { Agree } \\
\text { I would be an effective preceptor. }\end{array}$ & $\begin{array}{c}\text { Strongly } \\
\text { Agree }\end{array}$ \\
\hline $\begin{array}{l}\text { I would need training before precepting } \\
\text { a dietetic intern. }\end{array}$ & & & & & \\
\hline $\begin{array}{l}\text { I am confident I have the knowledge } \\
\text { and skills to precept. }\end{array}$ & & & & & \\
\hline $\begin{array}{l}\text { I would be more likely to precept if I had } \\
\text { access to an On-Call specialist. i.e. to } \\
\text { answer questions related to my area of } \\
\text { practice while precepting }\end{array}$ & & & & & \\
\hline
\end{tabular}

Q264 When you were a dietetic intern, how satisfied were you with your preceptor experiences?

\begin{tabular}{|l|l|l|l|l|l|l|}
\hline & $\begin{array}{c}\text { Very } \\
\text { Dissatisfied }\end{array}$ & Dissatisfied & Neutral & Satisfied & $\begin{array}{c}\text { Very } \\
\text { Satisfied }\end{array}$ & $\begin{array}{c}\text { Not } \\
\text { Applicable }\end{array}$ \\
\hline $\begin{array}{l}\text { Satisfaction with } \\
\text { your preceptors }\end{array}$ & & & & & & \\
\hline
\end{tabular}

Q91 If it was solely your decision, would you resume taking interns?

Yes

Maybe (include reason)

No (include reason) 
Q92 What is (or was) your primary practice area?

Academia (or college/university faculty)

Business \& Industry

Communication/Publication

Community/Public Health

Consultation and Private Practice

Culinary

Food Service

Government or State Agency

Health Care

School Nutrition

Wellness

Other:

Q93 Years have served as a dietetic internship preceptor in the US: Please round to the nearest year (i.e. 1)

Q259 When did you last precept? Please include a number that indicates the number of years ago you last precepted (i.e. if you last precepted about 2 years ago, indicate 2 )

Q94 Total number of dietetic interns precepted over your career: If you are not sure please provide the closest number without going over.

Q95 Thank you for continuing, your responses are important and your time is appreciated!

Q96 Years working in field of nutrition/dietetics:

Q97 Years working in current, or most recent, position:

Q234 In what state do you currently work? If not working, in which state do you reside? (select one)

Please select a state from this list

I do not reside in the United States

Q228 How would you describe the area where you work? (select one)If not working, please refer to the area in which you live.

Urban (i.e. densely populated, city)

Suburban

Rural

Other: 
Q99 Highest degree completed in nutrition/dietetics related field:

Bachelors

Masters

Doctorate

Q100 Additional specialization credentials hold (check all that apply):

Board Certified Specialist in Pediatric Nutrition (CSP)

Board Certified Specialist in Gerontological Nutrition (CSG)

Board Certified Specialist in Oncology Nutrition

Board Certified Specialist in Renal Nutrition (CSR)

Board Certified Specialist in Sports Nutrition (CSSD)

Certified Diabetes Educator (CDE)

Certified Nutrition Support Clinician (CNSC)

Other(s):

Not Applicable

Q252 Are you teaching outside of the preceptor role?

Yes

No

Q254 You responded yes to teaching outside of the preceptor role, please indicate in what capacity you are teaching? Choose all that apply.

Dietetic Internship Program

University/College

Hospital/Medical Center

Other

Q102 Have you held a professional leadership position? (leadership position could be held in any setting, such as schools, food service institutions, clinical settings, corporations, etc. and includes administration/management/supervisor positions, elected position, etc.)

Yes, currently hold a leadership position

Yes, previously held a leadership position

No, never

Q103 Are you an Academy of Nutrition and Dietetics (AND) member?

Yes

Former Member

Never 
Q104 Are you a member of the Nutrition and Dietetic Educators and Preceptors (NDEP) Dietetic Practice Group (DPG) of AND?

Yes

Former Member

Never

Q105 What is your age in years?

Q106 What gender do you identify yourself as?

Female

Male

Transgender or Other

Q107 What ethnicity/race do you identify yourself as?

American Indian or Alaskan Native

Asian or Pacific Islander

Black (not of Hispanic origin)

Hispanic

White (not of Hispanic origin)

Other ethnicity/race (specify):

Q256 If you have additional comments you wish to include related to precepting or any of the survey questions please include here:

Are you willing to be contacted in the next 3 weeks to test reliability of this survey?

Yes

No

Q108 If you have additional comments you wish to discuss further, include your preferred contact information below or please e-mail slb2131@tc.columbia.edu or call 201-370-3991.

Phone:

E-mail:

Other:

Q109 Browser Meta Info

Browser

Version

Operating System

Screen Resolution

Flash Version

Java Support

User Agent 


\section{Appendix G}

RD Main Survey E-mail

\section{RD Main Survey E-mail}

From: Summer Butler, MA, RDN

Subject: RD Survey-Please help include your feedback!

\section{Dear fellow RD:}

Our profession is on the rise! It is projected that by 2020 the field may only be able to meet $75 \%$ of the need for dietetics professionals. To increase the number of RDs to meet this demand there needs to be an increase in the number of slots available for interns to complete supervised practice requirements and better ways to recruit and maintain preceptors. You have been selected to help us understand why RDs may or may not choose to precept. Your input is important to us!

Follow this link to the survey, it will take $\sim \mathbf{1 0 - 1 5}$ minutes to complete and you can be entered into a drawing to receive one of five $\mathbf{\$ 4 0}$ gift cards:

[link will populate here]

If you leave the survey at any point, your responses will be saved and you may return to where you left off via the survey link above.

I received your e-mail address from the Commission on Dietetics Registration to send out this survey secondary to your registration status as an RD or RDN. I am an RDN and an EdD candidate in Nutrition and Public Health working towards completing the requirements for a doctoral degree at Teachers College, Columbia University, New York, NY. Participation in this survey is voluntary and you are free to withdraw at any time. Your participation and survey responses will be kept confidential.

If you have any questions regarding your participation in this survey please contact me at 201-370-3991 or my faculty research advisor Dr Pamela Koch at 212-678-3001 (Teachers College IRB \#16-276).

In addition, at the end of the survey, you will be asked if you are willing to complete it again 1-3 weeks later to ensure the quality of the survey. This is completely optional.

\section{Thank you in advance for your time and participation,}

Summer Butler, MA, RDN, EdD Candidate in Nutrition and Public Health

Department of Health \& Behavior Studies, Program in Nutrition

Teachers College, Columbia University, New York, NY

201-370-3991 or slb2131@ tc.columbia.edu 
Appendix $\mathrm{H}$

RD Main Survey Reminder E-mail

\section{RD Main Survey Reminder E-mail}

From: Summer Butler, MA, RDN

Subject: RD Survey-Please help include your feedback!

This is a reminder e-mail, if you have already completed this online survey please disregard.

Dear fellow RD:

Our profession is on the rise! It is projected that by 2020 the field may only be able to meet $75 \%$ of the need for dietetics professionals. To increase the number of RDNs to meet this demand there needs to be an increase in the number of slots available for interns to complete supervised practice requirements and better ways to recruit and maintain preceptors. You have been selected to help us understand why RDNs may or may not choose to precept. Your input is important to us!

Follow this link to the survey, it will take $\sim 10-15$ minutes to complete and you can be entered into a drawing to receive one out of five $\mathbf{\$ 4 0}$ gift cards:

[link will populate here]

If you leave the survey at any point, your responses will be saved and you may return to where you left off via the survey link above.

I received your e-mail address from the Commission on Dietetics Registration to send out this survey secondary to your registration status as an RD or RDN. I am an RDN and an EdD candidate in Nutrition and Public Health working towards completing the requirements for a doctoral degree at Teachers College, Columbia University, New York, NY. Participation in this survey is voluntary and you are free to withdraw at any time. Your participation and survey responses will be kept confidential.

If you have any questions regarding your participation in this survey please contact me at 201-370-3991 or my faculty research advisor Dr Pamela Koch at 212-678-3001 (Teachers College IRB \#16-276).

In addition, at the end of the survey, you will be asked if you are willing to complete it again 1-3 weeks later to ensure the quality of the survey. This is completely optional.

Thank you in advance for your time and participation,

Summer Butler, MA, RDN, EdD Candidate in Nutrition and Public Health

Department of Health \& Behavior Studies, Program in Nutrition

Teachers College, Columbia University, New York, NY

201-370-3991 or slb2131@ tc.columbia.edu 
Appendix I

RD Main Survey Retest E-mail

From: Summer Butler, MA, RDN

Subject: You completed an RD survey, need your help to ensure quality data

\section{Dear fellow RD:}

You recently completed an online RD survey related to why RDs may or may not precept and you indicated you would be willing to complete the survey again in 1 to 3 weeks to help us ensure the quality of the survey.

Please follow this link to retake the survey. It will take $\sim \mathbf{1 0 - 1 5}$ minutes to complete:

[link will populate here]

If you leave the survey at any point, your responses will be saved and you may return to where you left off via the survey link above.

As a reminder, I received your e-mail address from the Commission on Dietetics Registration to send out this survey secondary to your registration status as an RD or RDN. I am an RDN and an EdD candidate in Nutrition and Public Health working towards completing the requirements for a doctoral degree at Teachers College, Columbia University, New York, NY. Participation in this re-test survey is voluntary and you are free to withdraw at any time. Your participation and survey responses will be kept confidential.

If you have any questions regarding your participation in this survey please contact me at 201-370-3991 or slb2131@ tc.columbia.edu or my faculty research advisor Dr Pamela Koch at 212-678-3001 (Teachers College IRB \#16-276).

Thank you in advance for your time and participation,

Summer Butler, MA, RDN, EdD Candidate in Nutrition and Public Health

Department of Health \& Behavior Studies, Program in Nutrition

Teachers College, Columbia University, New York, NY

201-370-3991 or slb2131@tc.columbia.edu 
Appendix $\mathbf{J}$

RD Main Survey Retest Reminder E-mail

From: Summer Butler, MA, RDN

Subject: You completed an RD survey, need your help to ensure quality data

This is a reminder e-mail, only if you have already completed the survey a second time please disregard.

\section{Dear fellow RD:}

You recently completed an online RD survey related to why RDs may or may not precept and you indicated you would be willing to complete the survey again in 1 to 3 weeks to help us ensure the quality of the survey.

Please follow this link to retake the survey. It will take $\sim 10-15$ minutes to complete:

[link will populate here]

If you leave the survey at any point, your responses will be saved and you may return to where you left off via the survey link above.

As a reminder, I received your e-mail address from the Commission on Dietetics Registration to send out this survey secondary to your registration status as an RD or RDN. I am an RDN and an EdD candidate in Nutrition and Public Health working towards completing the requirements for a doctoral degree at Teachers College, Columbia University, New York, NY. Participation in this re-test survey is voluntary and you are free to withdraw at any time. Your participation and survey responses will be kept confidential.

If you have any questions regarding your participation in this survey please contact me at 201-370-3991 or slb2131 @ tc.columbia.edu or my faculty research advisor Dr Pamela Koch at 212-678-3001 (Teachers College IRB \#16-276).

Thank you in advance for your time and participation,

Summer Butler, MA, RDN, EdD Candidate in Nutrition and Public Health Department of Health \& Behavior Studies, Program in Nutrition Teachers College, Columbia University, New York, NY 201-370-3991 or slb2131@ tc.columbia.edu 


\author{
Appendix K \\ RD Main Survey Consent \\ Teachers College, Columbia University \\ 525 W 120th Street, New York, NY 10027
}

Consent is $Q 1$ of online survey

Our profession is on the rise! You have been selected to help us better understand why RDNs may or may not choose to precept. Your participation in this online survey will take approximately 10-15 minutes to complete.

Your input is important to us and as part of your participation you will be entered into a drawing to win one of five $\mathbf{\$ 4 0}$ gift cards.

There is minimal risk, equivalent to completing an online survey, associated with completing this questionnaire. Participation in this survey is voluntary and you are free to withdraw at any time without penalty.

Participation in the survey and your responses will be kept confidential, and electronic information will be password protected. There is no direct benefits to you for participating but-responses may help to better inform recommendations and strategies related to recruiting and sustaining preceptors.

This survey is being conducted by Summer Butler, MA, RDN, and EdD candidate in Nutrition and Public Health at Teachers College, Columbia University. Her dissertation and research is related to the preceptor shortage and is aimed at understanding more about RDs and precepting.

If you have any questions regarding your participation in this survey, please contact the principal investigator (Summer Butler 201-370-3991, slb2131@tc.columbia.edu) or the research advisor (Dr. Pamela Koch 212-678-3001). If you have any comments, questions or concerns regarding the conduct of the research or your rights as a participant, please contact Teachers College, Columbia University Institutional Review Board/IRB at 212678-4105 (IRB ID: 16-276).

If you are 18 years of age or older, understand the information provided, and consent to participate in this study, please choose 'I agree' below to begin the survey.

O I agree

O I do not agree

If I do not agree Is Selected, Then Skips To End of Survey 
Appendix L

RD Main Survey

Online via Qualtrics.

Participants will not see question \#'s and online format is more user friendly/visibly more appealing than how views here in word.

Note: The letters $C, F$ and/or $N$ that appear by the question numbers or statements in this document refer to which participants will see the question or statement indicated, $C=$ current preceptors, $\boldsymbol{F}=$ former preceptors, $\boldsymbol{N}=$ never precepted. If there is a question number or statement with no letter indicated, all participants will see the question.

1. Consent - only continues if participant agrees.

2. Your responses and feedback are appreciated. Thank you in advance for your time and participation!

3. Are you a Registered Dietitian (RD) or Registered Dietitian Nutritionist (RDN)?

O Yes

O No - Skips to End of Survey If $=$ No

\section{What is your preceptor status?}

O Never precepted for a US accredited Dietetic Internship program

O Former preceptor (precepted greater than 12 months ago) for a US accredited Dietetic Internship program

O Current preceptor (precepted within the past 12 months) for a US accredited Dietetic Internship program

4C. For the position at which you most recently were a preceptor was being a preceptor:

O required

not required

O not sure 
4FN. For your current or most recent position, is/was being a preceptor:

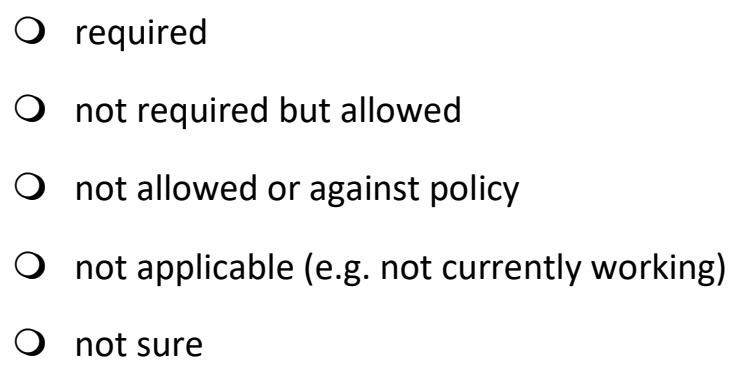

5CF. Years you have served as a dietetic internship preceptor in the US:

Please round to the nearest year (i.e. enter 1 if one year or less).

Note: answer box is set to allow up to two numerical digits (no words).

\section{C. Typical number of interns precept in 1 year? \\ $6 \mathrm{~F}$. When you were a preceptor, typical number of interns precepted in 1 year?}

Note: answer box is set to allow up to two numerical digits (no words).

6.5F. When did you last precept? Please include a number that indicates the number of years ago you last precepted (please round to the nearest year, e.g. 2).

Note: answer box is set to allow up to two numerical digits (no words).

7C. We are interested in understanding the rotation for which you primarily precept based on your most current experience. Please complete the sentence below by selecting the ONE rotation which best describes the area for which you precept.

I typically precept during the dietetic intern's rotation.

7F. We are interested in understanding the rotation for which you primarily precepted based on your most recent experience. Please complete the sentence below by selecting the ONE rotation which best describes the area for which you precepted. 
I typically precepted during the dietetic intern's rotation.
Inpatient Clinical/Medical Nutrition Therapy (i.e. hospital, long term care, rehab)
Outpatient Medical Nutrition Therapy, Community Nutrition (i.e. food banks, community centers, WIC)
Food Service Management
Research
Other:

Displays the following Question: If I typically precept during the dietetic intern's rotation. Choose the ONE rotation you... = Inpatient Clinical/Medical Nutrition Therapy (i.e. hospital, long term care, rehab)

8C. You responded that you primarily precept during the intern's Clinical/Medical Nutrition Therapy (inpatient) rotation, please specify the location where you primarily precept: Choose only one location unless you precept in more than one location equally.

8F. You responded that you primarily precepted during the intern's Clinical/Medical Nutrition Therapy (inpatient) rotation, please specify the location where you primarily precepted: Choose only one location unless you precepted in more than one location equally.

Hospital (acute care)

Nursing Home (long term care) or Transitional Care

Rehabilitation

Other:

9C. Are you the primary preceptor for the dietetic interns' rotation(s)?

(i.e. signing off on evaluations, hours, etc. that are returned to the internship program)

9F. Were you the primary preceptor for the dietetic interns' rotation(s)?

(i.e. signed off on evaluations, hours, etc. that were returned to the internship program)

O No

Not sure

Yes, sometimes

Yes, always 
10C. While precepting, what is the typical number of weeks one intern rotates with (or is assigned to) you during their rotation:

10F. While precepting, what was the typical number of weeks one intern rotated with (or was assigned to) you during their rotation:

Note: answer box is set to allow up to two numerical digits (no words).

11C. When you have a dietetic intern, how many hours per week on a typical week is each intern assigned to you?

$11 \mathrm{~F}$. When you had a dietetic intern, how many hours per week on a typical week was each intern assigned to you?

Note: answer box is set to allow up to two numerical digits (no words).

11.5FN. In the past 12 months, at your current place of work/employment, have other RDNs or RDs precepted dietetic interns?
No
O Yes
Do not know
Not applicable

11.6FN. Are you currently eligible to precept for a US accredited Dietetic Internship program?

No, not eligible to precept, explain:

Do not know if eligible to precept, explain:

Yes, eligible to precept

11.7N. Have you ever been asked to serve as a preceptor for a US accredited (i.e. accredited by CADE/ACEND) Dietetic Internship program?
○ No
○ Not sure
○ Yes 
Note for Scales Below: Response options for all of the statements will be on a 6 point likert scale from strongly disagree to strongly agree, unless indicated otherwise.

NOTE: For the following likert-type questions, if you are using a mobile device or touch screen, holding your device long ways/horizontal may give you a quicker view to complete response options.

\section{Potential Benefits of Precepting}

Choose the response which best describes your feelings about the statement.

As a preceptor I have the opportunity to... (C)

As a preceptor I had the opportunity to... (F)

As a preceptor I would have the opportunity to... (N)

\begin{tabular}{|c|c|c|c|c|c|c|}
\hline & $\begin{array}{l}\text { ngly } \\
\text { gree }\end{array}$ & Disagree & $\begin{array}{l}\text { Somewhat } \\
\text { Disagree }\end{array}$ & $\begin{array}{l}\text { Somewhat } \\
\text { Agree }\end{array}$ & Agree & $\begin{array}{l}\text { Strongly } \\
\text { Agree }\end{array}$ \\
\hline Learn from dietetic interns & 0 & $\mathrm{O}$ & 0 & 0 & 0 & 0 \\
\hline $\begin{array}{l}\text { Keep current and remain } \\
\text { stimulated in my } \\
\text { profession }\end{array}$ & $\mathrm{O}$ & O & $\mathrm{O}$ & 0 & $\mathrm{O}$ & O \\
\hline $\begin{array}{l}\text { Increase my own } \\
\text { professional knowledge } \\
\text { base }\end{array}$ & O & O & O & O & 0 & 0 \\
\hline Improve my teaching skills & O & 0 & O & O & 0 & O \\
\hline $\begin{array}{l}\text { Improve my organizational } \\
\text { skills }\end{array}$ & O & O & O & O & O & $\mathrm{O}$ \\
\hline $\begin{array}{l}\text { Improve my leadership } \\
\text { skills }\end{array}$ & 0 & O & O & 0 & 0 & 0 \\
\hline
\end{tabular}




\section{The Preceptor Role}

Choose the response which best describes your feelings about the statement.

(see 6 pnt scale for each item strongly disagree to strongly agree)

Being a preceptor inspires me to perform my best (C, F)

Being a preceptor would inspire me to perform my best $(\mathrm{N})$

My philosophy of practice and the expectations of the preceptor role are aligned

I care about the fate of preceptors conducting supervised practice in dietetics

Deciding to be a preceptor was a mistake on my part (C, F)

Deciding to be a preceptor would be a mistake on my part (N)

I feel a sense of loyalty to the preceptor role

There is not much to be gained by acting as a preceptor

I am proud to tell others that I am a preceptor (C)

I am proud to tell others that I was a preceptor (F)

I would be proud to tell others that I was a preceptor (N)

I am willing to put in a great deal of effort beyond what is normally

expected in order to help the intern be successful $(C, F)$

I would be willing to put in a great deal of effort beyond what is normally expected in order to help the intern be successful $(\mathrm{N})$

I am enthusiastic about the preceptor role when I talk to my colleagues 


\section{Support for the Preceptor Role}

Please consider each statement with reference to your experience as a dietetic internship preceptor. (C, F)

Please consider each statement imagining what support you think there would be for the preceptor role. If helpful you may also think about preceptors you know or about the support your preceptors received during your internship. (N)

Choose the response which best describes your feelings about the statement. (all)

6 point likert scale response options for each statement from strongly disagree to strongly agree

I feel I have had adequate support from the Dietetic Internship Program(s) (C, F)

If I were a preceptor, I feel I would have adequate support from the Dietetic Internship Program(s) (N)

The goals as a preceptor are clearly defined

Preceptors have adequate preparation for their role

Support is available to help preceptors develop in their role

There are adequate opportunities for preceptors to share information with other preceptors

The workload of an RD is still manageable when functioning as a preceptor

Co-workers are typically supportive of RDs when they function as a preceptor

Co-workers are supportive when preceptors have to spend extra time with a challenging intern

Management/administration are supportive of RDs in the preceptor role

15. Please continue, your attention to detail in your response is appreciated.

$16 \mathrm{aC}$. Choose the response which best describes if the statement is related to why you precept dietetic interns.

Reasons I precept... (C)

16aF. Choose the response which best describes if the statement is related to why you precepted dietetic interns.

Reasons I precepted... (F) 
$16 \mathrm{aN}$. Choose the response which best describes if the statement is related to why you would precept dietetic interns.

Reasons I would precept... (N)

6 point likert scale response options for each statement from strongly disagree to strongly agree

Interns create positive change for the department/organization

It is my professional responsibility

My personal relationship with the Dietetic Internship Program/Director

It is required by my workplace

There are tangible benefits such as, tuition credit, continuing education units, monetary compensation, etc.

To contribute to the future of the profession

To give back to the field

To learn from the intern/keep up-to-date

To network/stay connected

To screen potential employees or job recruit

To get experience teaching and mentoring

To introduce students and interns to the field

$16 \mathrm{bC}$. Please describe any other reason(s) why you precept that may have not already been mentioned above.

$16 \mathrm{bF}$. Please describe any other reason(s) why you have precepted that may have not already been mentioned above.

$16 \mathrm{bN}$. Please describe any other reason(s) why you would precept that may have not already been mentioned above. 
17CF. Have you ever RECEIVED any of the following for precepting dietetic intern(s)? Check ALL that apply. Note: There is a 'None of the Above' option at the bottom if applicable.

RECEIVED for precepting

Academy of Nutrition and Dietetics (AND) membership paid

Access to library resources (i.e. electronic journals)

Commission on Dietetic Registration (CDR) dues paid

Continuing Professional Education Unit offerings (not including for precepting itself)

Continuing Professional Education Units for precepting

Dietetic Practice Group (DPG) membership paid

Expenses paid toward a national conference

Faculty appointment and/or faculty benefits/development opportunities

Hot topic/Best Practice updates

Official designation/title for being a preceptor

Pay or monetary compensation/gift card

Peer/public recognition

Reduction in my regular workload while precepting

Tuition credit, waivers, discounts, or reimbursement

Other:

Other:

None of the Above 
18. Please look at the list of potential incentives below and indicate whether they would increase the likelihood that you would act as a preceptor.

Please reserve "very likely" for only those incentives that are very important to you.

Abbreviations: $A N D=$ Academy of Nutrition and Dietetics, $C D R=$ Commission on Dietetics

Registration, CPEU=Continuing Professional Education Units, DPG=Dietetic Practice Group

$\begin{array}{lll}\text { Not } & \text { Somewhat } & \text { Very } \\ \text { Very } & \text { Likely } & \text { Likely } \\ \text { Likely } & & \end{array}$

AND membership fee paid

Access to library resources (i.e. electronic journals)

CDR annual fee paid

CPEUs for precepting

CPEU offerings (not including for precepting itself)

DPG membership fee paid

Expenses paid toward a national conference

Faculty appointment and/or faculty benefits/development opportunities

Hot topic/Best Practice updates

Official designation/title for being a preceptor

Pay or monetary compensation/gift card

Peer/public recognition

Reduction in my regular workload

Tuition credit, waivers, discounts, or reimbursement

$\begin{array}{ll}0 & 0 \\ 0 & 0 \\ 0 & 0 \\ 0 & 0 \\ 0 & 0 \\ 0 & 0\end{array}$
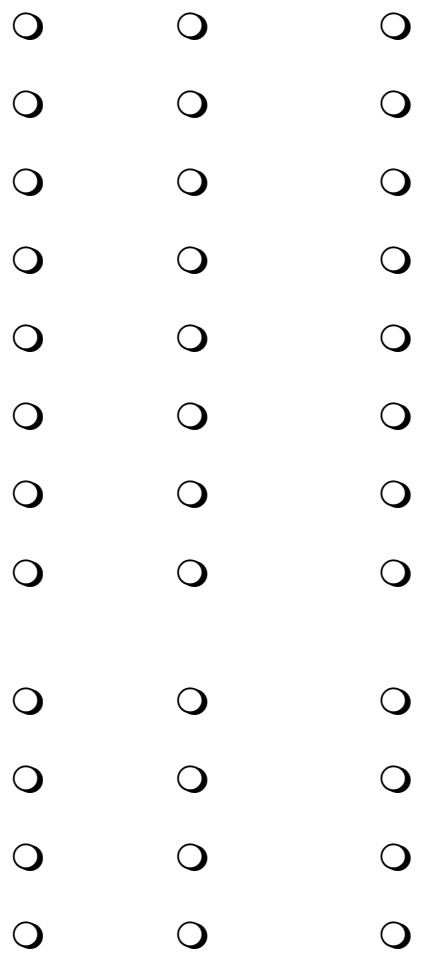

$0 \quad 0 \quad 0$

19C. Is there anything else that would motivate or incentivize you to continue to precept, or precept dietetic interns more often, that we haven't already covered?

$19 F N$. Is there anything else that would motivate or incentivize you to precept dietetic interns that we haven't already covered? 


\subsection{F. Reason(s) I stopped precepting dietetic interns:}

\section{Check ALL that apply.}

Change in management

Changed jobs/positions, resigned, retired

Company lost account or merger

Instructed by Director/Manager/Supervisor/Coordinator

Instructed by Human Resources

Instructed by Owner, CEO, or Senior Staff/Administration

No contract or contract issues with internship

Not working or on leave of absence

Stress or personal circumstances

Technology or electronic medical record (EMR) related

Too much paperwork

Unable to demonstrate added value of precepting interns

Workload or short staffed

Workspace limitations

Other(s) 
20. Please read the statements below and indicate how strongly you agree or disagree that they act as BARRIERS to you precepting (or precepting more often).

20FN. Please read the statements below and indicate how strongly you agree or disagree that they act as BARRIERS to you precepting.

6 pnt scale options for each item from strongly disagree to strongly agree

lack of appreciation/recognition

lack of incentives (i.e. financial compensation)

lack of personal motivation

lack of preceptor support

lack of preceptor training

length of rotation

length of intern onboarding process (e.g. employee health)

legal issues (i.e. internship contracts or agreements)

liability/regulatory concerns (e.g. intern errors with clients)

my health and/or family/personal obligations

not enough for interns to do at my workplace

negative experience with internship program/prior intern

quality of the intern(s)

quality of the internship program

restricted by facility or management

short staffed or down-sizing

state licensure/certification regulations

increased stress from having interns (moved up to first item in qualtrics)

technology or electronic medical record issues

time consuming/increased workload

unable to demonstrate added value of having interns

unfamiliar with an internship program

workspace limitations 
21C. Are there any other barriers to you precepting (or precepting more often) that we haven't already covered?

21FN. Are there any other barriers to you precepting that we haven't already covered?

22CFN. When you were a dietetic intern, how satisfied were you overall with your preceptor experiences?

$\begin{array}{lccccc} & \begin{array}{l}\text { Very } \\ \text { Dissatisfied }\end{array} & \text { Dissatisfied } & \text { Satisfied } & \begin{array}{l}\text { Very } \\ \text { Satisfied }\end{array} & \begin{array}{l}\text { Not } \\ \text { Applicable }\end{array} \\ \begin{array}{l}\text { Satisfaction } \\ \text { with your } \\ \text { preceptors }\end{array} & 0 & 0 & 0 & 0 & 0\end{array}$

\section{Satisfaction with Precepting}

Please consider each statement with reference to your experience as a dietetic internship preceptor. (C, F)

Please consider each statement with how you would imagine your experience to be as a dietetic internship preceptor. If helpful you may also think about preceptors you know or about the support your preceptors received during your internship. (N)

Please indicate how strongly you agree or disagree with the following statements. (all)

6 pnt likert scale options for each item from strongly disagree to strongly agree

I am satisfied with the incentives offered/received for precepting

Being a preceptor is satisfying

The role of preceptor is professionally rewarding

I enjoy the intern/preceptor interaction

The preceptor role is an incentive to teach

It is stimulating to work with enthusiastic interns 
23.5FN. Please indicate how strongly you agree or disagree with the following statements related to precepting a dietetic intern.

6 pnt likert scale options for each item from strongly disagree to strongly agree

I would be an effective preceptor

I would need training before precepting a dietetic intern

I am confident I have the knowledge and skills to precept

I would be more likely to precept if I had access to an On-Call Specialist. i.e. to answer questions related to my area of practice while precepting

\author{
24aCFN. Have you received preceptor training? \\ O No \\ Yes
}

Displays the following Question: If Have you received preceptor training? = Yes

$24 \mathrm{bCFN}$. Have you received any of the following preceptor trainings?

No Yes

Formal Training (i.e.

O

structured, class, online

training)

Informal Training (i.e.

unstructured, written

resources)

26CFN. In your current or most recent position, were you involved in the final decision to precept, or not to precept?
No
Y Yes
Not applicable 
27CFN. When you were a dietetic intern, were you in a distance learning internship program?
No
Yes
Not applicable

27.1CFN. When you were a dietetic intern, what type of internship program were you in?

College/University based

Company based (e.g. business: Sodexo, Aramark, etc.)

Federal or State Agency

Hospital/Health Care Facility based

Other:

Not Applicable

28C. If it was solely your decision, would you continue taking interns?

$28 \mathrm{~F}$. If it was solely your decision, would you resume taking interns?

$28 \mathrm{~N}$. If it was solely your decision, would you take interns?

No (include reason):

Yes (include reason):

28.5FN. If you were able and willing to precept, do you know how to sign up to precept dietetic Interns?
○ No
- Yes 


\subsection{FN. What is (or was) your primary practice area?}
- Academia (or college/university faculty)
- Business \& Industry/Corporate
- Communication/Publication
- Community/Public Health
- Consultation, Private Practice
- Culinary
- Food Service
○ Government, Federal or State Agency
- Health Care (i.e. clinical)
- School Nutrition
○ Wellness
○ Other:

\section{DEMOGRAPHIC QUESTIONS FOR ALL ARE BELOW}

29. You are almost there, just a few more questions to help describe the Registered Dietitians participating in this survey.

\section{Are you currently working in the field of nutrition/dietetics?}

Yes, full time

Yes, part time

Yes, per diem or other

No, out of the field for 1 year or less

No, out of the field for more than 1 year

\section{How many years have you been an RD or RDN?}

Note: answer box is set to allow up to two numerical digits (no words). 
32. Years working in current, or most recent, position:

Note: answer box is set to allow up to two numerical digits (no words).

33. In what state do you currently work? If not working, in which state do you reside? (select one)

$\boldsymbol{\nabla}$ Please select a state from this list ... I do not reside in the United States

34. How would you describe the area where you work? (select one) If not working, please refer to the area in which you live.

Urban (i.e. densely populated, city)

Suburban (i.e. just within or just outside city boundaries)

Rural (i.e. countryside, open space)

Other:

35. Highest degree completed in nutrition/dietetics related field:

Bachelors

O Masters

Doctorate

36a Do you hold a specialization credential in the field of nutrition/dietetics?

O No

O Yes 
Displays the following Question: If Do you hold a specialization credential in the field of nutrition/dietetics? $=$ Yes

36b. Additional specialization credential(s) hold (check all that apply):

- Advanced Practice Certification in Clinical Nutrition (RD-AP, RDN-AP)

- Board Certified Specialist in Pediatric Nutrition (CSP)

- Board Certified Specialist in Gerontological Nutrition (CSG)

- Board Certified Specialist in Obesity and Weight Management

- Board Certified Specialist in Oncology Nutrition (CSO)

○ Board Certified Specialist in Renal Nutrition (CSR)

- Board Certified Specialist in Sports Dietetics (CSSD)

- Certified Diabetes Educator (CDE)

- Certified Nutrition Support Clinician (CNSC)

○ Other(s):

Not Applicable

\section{Are you teaching outside of the preceptor role?}

O No

Yes

No $Q 38$ was removed

\section{Please check all that may apply.}

O I am a Dietetic Internship (DI) Director or Coordinator

I work for a DI program

O I work for ACEND

O I am on a DI advisory committee

O I am on a DI admissions committee

O N/A I do NOT work for a DI program or ACEND and I am not on a DI advisory committee or DI admissions committee 
40. Do you currently hold a professional leadership position in the field of nutrition/dietetics? Note: leadership position could be held in any setting, such as schools, food service institutions, clinical settings, corporations, etc. and includes administration/management/supervisor positions, elected position, etc.
No
Y Yes

Displays following Question: If Do you currently hold ....professional leadership position...? = Yes

41. You responded you currently hold a leadership position in nutrition/dietetics, please specify the setting(s). Choose all that apply.

Academia, college, university

Community/public health

Business \& industry/corporate

Food service

Government, federal or state agency

Health care (e.g. clinical)

Professional group (e.g. AND, ACEND, CDR, NDEP)

School nutrition

Other

43. Are you an Academy of Nutrition and Dietetics (AND) member?

No, never

No, former member

O Yes 
44. Are you a member of the Nutrition and Dietetic Educators and Preceptors (NDEP) Dietetic Practice Group (DPG) of AND?

O No, never

No, former member

O Yes

45. What is your age in years?

Note: answer box is set to allow up to two numerical digits (no words).

46. What gender do you identify yourself as?

O Female

O Male

Transgender

other:

47a. What ethnicity do you identify yourself as?

Hispanic

O Non-Hispanic

47b. What race do you identify yourself as?

American Indian or Alaskan Native

Asian or Pacific Islander

Black

O White

O Mixed

Other (specify): 
48a. Did you know that as of June 2017 , RDNs can receive continuing education credit for precepting?

O No

Yes

48b. Knowing that you can receive continuing education credit for precepting (leadership activity type, 3 credits max/year), would that make you more likely to precept?

Not applicable: I would precept with or without continuing education credits

No, no amount of continuing education credits would make it more likely for me to precept

Maybe, if I could receive more than 3 credits a year

Yes, receiving continuing education credits somewhat increases my likelihood to precept

Yes, receiving continuing education credits greatly increases my likelihood to precept

48c. If you have additional comments related to precepting (benefits, support, incentives, motivators, satisfaction, barriers, commitment, etc.) or any of the questions in this survey please include here:

49. Please indicate if you would be willing to be recontacted within 1 to 3 weeks to complete the survey again so that we can further test the quality of our instrument?
Y Yes
O No

50. Browser Meta Info 